\title{
A study of morpheme order acquisition in an EFL corpus of $L 1$ Spanish - L2 English: Some pedagogical implications
}

Trabajo Fin de Máster (TFM) del Máster de profesorado de educación secundaria obligatoria y bachillerato, formación profesional y enseñanza de idiomas

Agustina Demarta Dabove

Supervised by Cristóbal Lozano

University of Granada

September 2012 


\section{Contents}

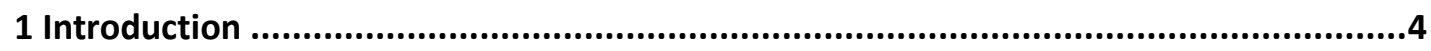

2 Second language acquisition and linguistic corpora .................................................6

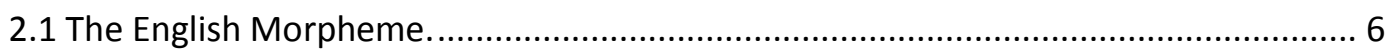

2.2 Relevant studies on the acquisition of morpheme order........................................ 8

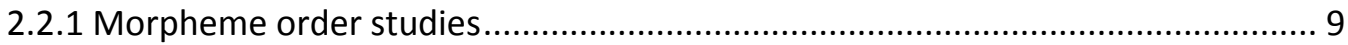

2.3 Learner corpora and learner corpus research ........................................................ 16

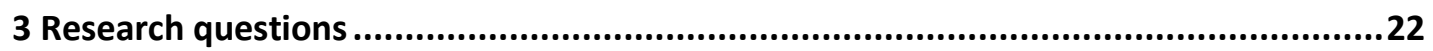

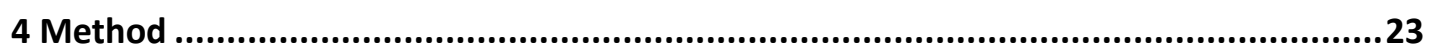

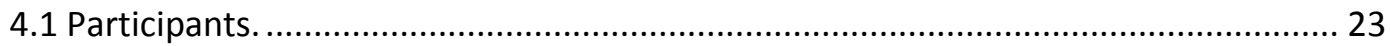

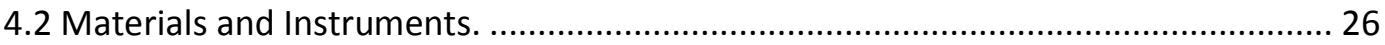

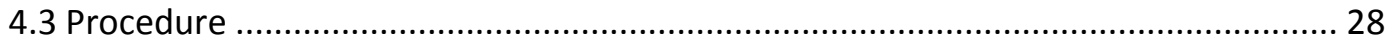

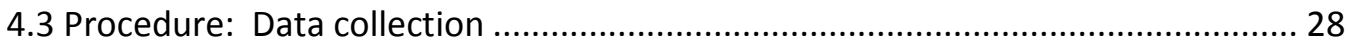

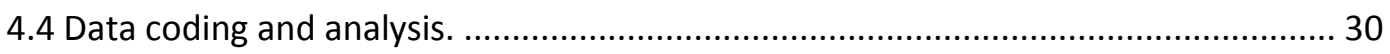

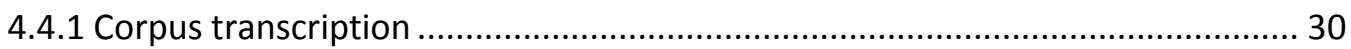

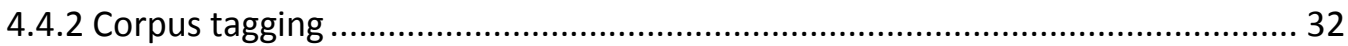

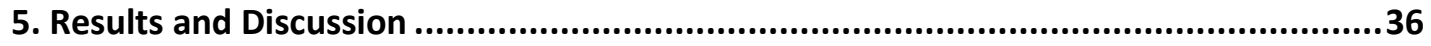

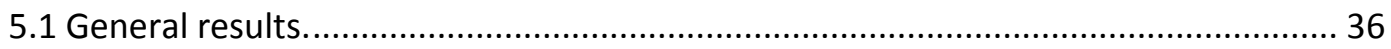

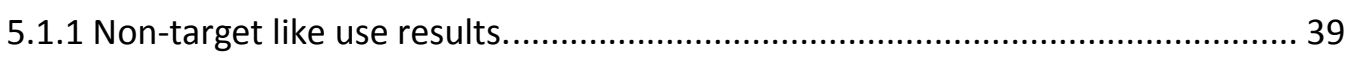

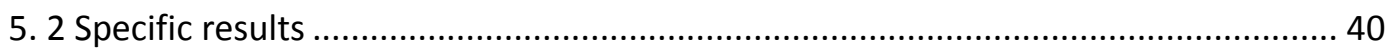

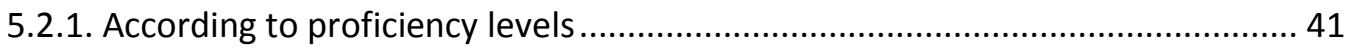

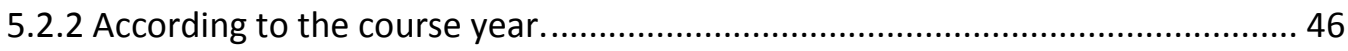

5.2.3 According to the usage of the morphemes .................................................... 51

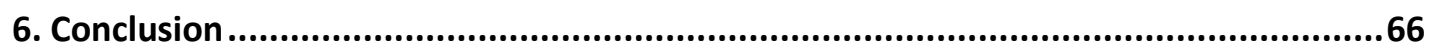

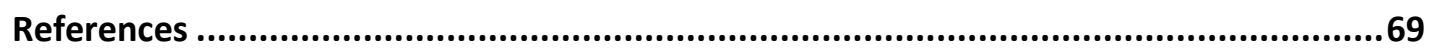

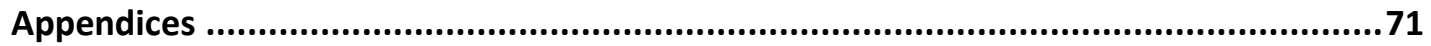

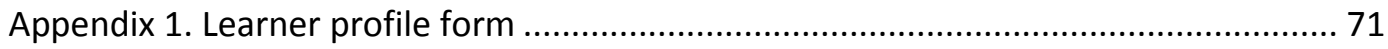

Appendix 2. Placement test (Cambridge University Press) …........................................ 72

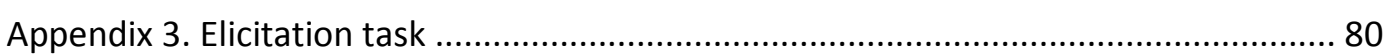

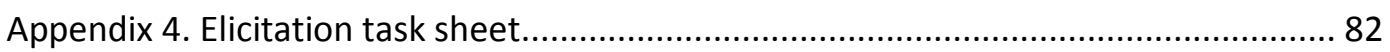

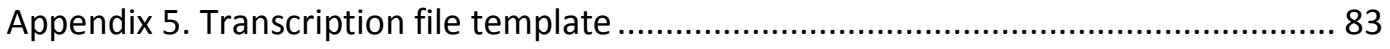

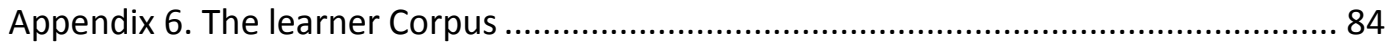

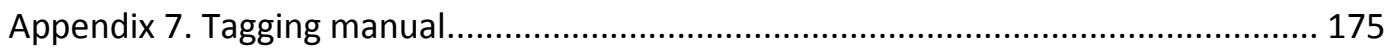

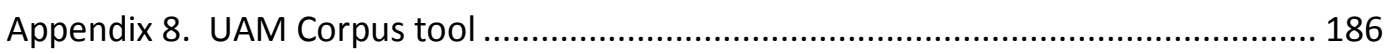

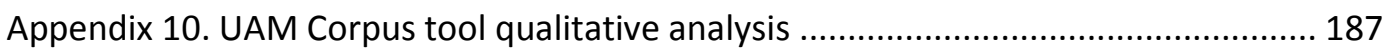

Appendix 11. UAM Corpus tool Data exploration ...................................................... 187 


\section{Acknowledgments}

I would like to express my sincere gratitude to the supervisor of this study Dr. Cristobal Lozano for his constancy, his patience, his motivation and his enthusiasm in the composition of this study. The support he has provided me has been crucial for the elaboration of this study.

I am also grateful to Dr. Ana Diaz Negrillo for her dedication in the process of this study, for the seminars she has prepared and for her unconditional help.

Juan Ardebol Barea also deserves a special mention for his help, wise pieces of advices and for the time we shared together during the elaboration of this study.

I cannot forget to thank both I.E.S Santa Catalina and I.E.S Cartuja for letting me carry out this study and I would like to send a special thanks to the participants because this study could not be fulfilled without their help.

I have taken efforts on this project. However it would not have been possible without the kind support and patience of my parents, siblings and friends. I would like to extend my sincere thanks to all of them, especially to my little sister, Marina Demarta, who loves English and who helped me in an active way with some parts of this study. 


\section{Introduction}

If we want to know what Second Language Acquisition is, we have to go back in time and locate ourselves in the 70s when Brown (1973) suggested that native speakers acquire grammatical morphemes in a specific order. Another example of this kind of studies is the one conducted by Bailey, Madden and Krashen in 1974. This study also deals with the same topic, that is, the morpheme order acquisition. It is important to highlight that, despite the fact that these studies were criticized because of their limitations due to the methodology used or the limited number of subjects, they provided important evidence that there is a given sequence in the acquisition of grammatical morphemes. Nowadays, recent MOS studies (see Tono, 2000; Kwon, 2005) have been carried out taking into account these limitations that the first MO studies had.

Tono (2000) could be seen as a useful example of this kind of studies because it focuses on how Japanese students acquire grammatical morphemes using a new methodology which consists of the creation of a learner corpus and its subsequent analysis.

Following Tono's example we have decided to conduct a MO study using a learner corpus based on the language produced by Spanish EFL students. The grammatical morphemes we analyzed were past regular -ed, past irregular, third person singular -s, present progressive -ing, copula be, auxiliary be, plural, articles and possessive -s. This morphemes' choice is influenced by Krashen's (1977) study "The Monitor Model" in which Krashen studies adult second language performance.

The completion of the present study relied on a process which started with the study of previous MOS. Once we set the topic, we decided to find out if our EFL students and the subjects of previously conducted MO studies (Brown 1973, Bailey, Madden and Krashen 1974; Dulay and Burt (1974). Therefore, this study consists of the collection of data in two state high schools in Jaen and Granada, the subsequent compilation of a Learner Corpus and its analysis and interpretation.

In this study several tools have been used. We believe that the UAM Corpus Tool deserves a special reference since it is a free software program designed for the annotation of text corpora and for data analysis. This instrument was used to tag, analyze and study the results of our Corpus project.

This dissertation has been organized in 6 main chapters: in the first chapter, i.e., the introduction, we present the aims of this study. The second chapter, Second Language Acquisition and Language Corpora, provides a review of the relevant studies on morpheme acquisition and language corpus. This chapter consists of three sub-sections: the morpheme, relevant studies, language corpora and learner corpora. In chapter 3, the Hypotheses research questions are stated. Chapter 4 consists of the description of the methodology used. In this regard we make reference to the participants, the materials, the procedure and the data coding and analysis. In chapter 5 we present the general and the specific results of our study regarding our subjects' accuracy rates in the use of the nine morphemes at issue. We should 
mention that in the analysis of our data we have taken into account other variables such as the students' age and their proficiency level, in this chapter we can also find the discussion and interpretation of our main findings. Finally, in chapter 6 the reader can find a conclusion in terms of the objectives, the positive points and the limitations of this study.

The aims of this dissertation are:

- To find out if there are similarities between our participants' morpheme acquisition order and the one that has been suggested by scholars such as Bailey, Madden \& Krashen (1974) or Brown (1973) despite the different scoring methods used.

- The collection and creation of an English learner corpus by Spanish EFL students.

- To find the pedagogical implications that a specific morpheme acquisition order can imply. That is to say, I would like to know if Spanish EFL students follow a certain sequence when they acquire the aforementioned nine morphemes in order to take it into account when we teach English. 


\section{Second language acquisition and linguistic corpora}

This chapter is organized into three main sections: the first one, i.e., "The English morpheme", provides a description of the 'smallest semantically meaningful constituents of words that can be identified' (Haspelmath 2002:3), the second section, "Second Language Acquisition", is based on a literature review of the MOS from their origins to their current studies. Lastly, the third section, "The Learner Corpora", describes its usage, the different types of corpus and their implications for SLA research.

\subsection{The English Morpheme.}

A description of the English morpheme is necessary in order to be familiar with the topic under investigation. Therefore, in this subsection we are going to define what a morpheme is and what kind of morphemes we can find in the English language. Then, we are going to provide a brief description of the morphemes that have been chosen in order to carry out this study.

'In two words: im- possible'

(Verbal slip attributed to the movie magnate, Samuel Goldwyn) ${ }^{1}$

After this useful quotation ('possible' is a word while 'im-' is a bound morpheme, in other words it is not a word. However the latter one is used as a word because of the negative meaning they carry itself) we are going to define the word morpheme. According to Norman C. Stargeberg in An introductory English grammar (2000, p.87), a short segment of language can be considered a morpheme if:

- It is a word or a part of a word which has meaning,

- It cannot be divided into smaller units or meaningful parts without violation of its meaning and

- It appears in different verbal environments with a relatively stable meaning.

According to the definition provided we can use the word date to find out if it meets all the criteria of a morpheme. First, we recognize it is a word, we can find it in a dictionary and therefore it has a meaning. Second it cannot be divided into smaller parts without violation of its meaning. For instance, although we could get smaller meaningful forms by dividing date such as ate we know that the meaning of ate violates the meaning of date. Finally, date recurs with a relatively stable meaning in such environments.

\footnotetext{
${ }^{1}$ From Alva Johnson's The great Goldwyn as quoted in Familiar Quotations, $15^{\text {th }}$ edition, by John Barlett, ed. By Emily Morison Beck. Boston: Little, Brown and Company, 1980, p.777
} 
Once a definition has been provided, let us go through the different kinds of morphemes. For example, scholars speak of free and bound morphemes, the latter is divided into derivational and inflectional morphemes; we can also distinguish between bases and affixes, and finally we have the allomorphs.

- A free morpheme is the one that can be uttered alone with meaning, such as words play, date, keep or hygiene. On the other hand a bound morpheme is always annexed to one or more morphemes to form a word, that is to say it cannot be uttered alone with meaning. For instance: played, dates, keeper or unhygienic where the italicized part are the bound.

- Bases and affixes: another classification of morphemes puts them into bases or affixes, bases are the parts of the word that have the principal meaning and affixes are bound morphemes that occurs before or within or after a base. It is important to know that there are three kinds: prefixes, infixes and suffixes; prefixes occur before a base unable, copilot or immortal, they are a small class of morphemes in English, around seventy five and their meaning are often those of English prepositions and adverbials; infixes are bound morphemes that have been inserted within a word; and finally suffixes are bound morphemes that occur after a base, normalizers (al-ize -er -s).

Bound morphemes could also be organized into two classes: Derivational morphemes which changing the meaning of words by applying derivations. In other words, derivation is the combination of a word stem with a morpheme, which forms a new word, which is often of a different class. For instance real becomes unreal, really.

On the other hand we have the inflectional morphology when the modification of a word is made to express different grammatical categories such as tense, grammatical mood, aspect, person, number, grammatical voice, gender and case. For instance cats, played, goes.

Finally here I present the nine morpheme forms we are going to work with throughout this study, in the next subsection we are going to express the reasons that made us choose these forms and how we are going to use them.

Six out of nine or our morphemes belongs to inflectional morphology: Plural -s : the books.

- Possessive (genitive): -s' John's book.

- $\quad 3 r d$ person singular nonpast -s He reads well.

- Progressive -ing He is working.

- Past tense -ed He worked.

- Past participle -en/-ed He has eaten/studied. 
We can also find that the comparative -er (the bigger one) and superlative -est form (the biggest one) also belong to the inflectional morphology however we are not going to work with them.

The other morphemes belong to the derivational morphology (copula be, auxiliary be and the article)

Table 1. List of morphemes studied

\begin{tabular}{|c|c|}
\hline Morpheme forms & Morpheme form examples \\
\hline Past regular '-ed' & Tom played in that team last year \\
\hline Past Irregular & John ate pizza last night \\
\hline Third person singular '-s' & She works very hard \\
\hline Present Progressive '-ing' & I am writing a 50 pages paper \\
\hline Copula 'Be' & He is awesome \\
\hline Auxiliary 'Be' & He is slipping to the cracks \\
\hline Plural & We are going to Tom's \\
\hline Possessive '-s' & I love the beauty and the beast \\
\hline Articles &
\end{tabular}

\subsection{Relevant studies on the acquisition of morpheme order}

We can define the term Second Language Acquisition as the acquisition of a new language in a foreign language context as well as the acquisition of a new language in a host language environment. This process could be placed when a first language is already established.

As we said before, this paper focuses on the study of the morpheme acquisition order that Spanish learners of English as a foreign language present. Therefore, its theoretical framework operates with the natural order hypothesis in second language learning, which holds that second language acquisition (SLA) is not just a matter of learned response, but that individuals developed second language acquisition competence according to a predictable series of benchmarks (Kwon,2005, p.2).

We can find that most of the second language researches have used children and young learners as their studies' subjects. That was mainly due to the fact that the initial hypothesis arose out of questions posed by developmental psycholinguists concerning the universality of child language learning strategies (Brown, 1973; Slobin 1973). However, a study by Fathman (1975) found no differences between children (6-10 yrs) and older children (11-15 yrs) on the order they acquired the morphemes forms. Moreover, 
Dulay \& Burt (1974) presented a researched where it was proved that English children acquired morphemes in a given sequence. This led Dulay, Burt and Krashen to suggest that "whatever internal factors are interacting with input in children to produce the results we see, they seem to be operating in adults as well" (1982:209). Indeed, Krashen (1977) suggested that there exists a natural order in the acquisition of English grammatical morphemes which does not depend on the mother tongue and the age of the L2 learner. However, this natural order is slightly different for second language learners; an L1 child and an L2 adult do not acquire the morphemes following the same order. In the next subsection we will explain the main morpheme studies in detail and we will also point the factors that shape that given sequence.

\subsubsection{Morpheme order studies}

All natural order studies follow a basic maxim: "there may be a consistent order in which first and/or second language learners acquire proficiency in the use of grammatical morphemes, which are traditionally defined in linguistic as "minimal unit[s] of meaning" (Johnson \& Johnson, 1998, p. 217; Kwon 2005, p.1).

There are seven major studies which deal with the order of acquisition of English morphemes in L1 and L2. Those studies are: Brown (1973), de Villers and de Villers (1973), Dulay \& Burt (1974b), Bailey, Madden, and Krashen (1974b), Larsen Freeman (1975), Hakuta (1976) and finally Rosansky (1976). 
Table 2. Order of Acquisition of English Morphemes in Major L1 and L2 studies. ${ }^{2}$

\begin{tabular}{|c|c|c|c|c|c|c|}
\hline \multicolumn{2}{|l|}{ L1 Studies } & \multicolumn{5}{|l|}{ L2 Studies } \\
\hline \multirow[t]{2}{*}{$\begin{array}{l}\text { R. Brown } \\
\text { (1973) }\end{array}$} & \multirow[t]{2}{*}{$\begin{array}{l}\text { de Villiers } \\
\text { and } \\
\text { de Villiers } \\
(1973)\end{array}$} & $\begin{array}{l}\text { Dulay } \\
\text { \& Burt } \\
\text { (1974b) }\end{array}$ & $\begin{array}{l}\text { Bailey, } \\
\text { Madden, } \\
\text { and Krashen } \\
(1974)\end{array}$ & $\begin{array}{l}\text { Larsen- } \\
\text { Freeman } \\
\text { (1975) }\end{array}$ & $\begin{array}{l}\text { Hakuta } \\
\text { (1976) }\end{array}$ & $\begin{array}{l}\text { Rosansky } \\
\text { (1976) }\end{array}$ \\
\hline & & $\begin{array}{l}\text { Children } \\
\text { (Spanish } \\
\text { and } \\
\text { Chinese) }\end{array}$ & $\begin{array}{l}\text { Adults } \\
\text { (classified } \\
\text { as Spanish } \\
\text { and non- } \\
\text { Spanish) }\end{array}$ & $\begin{array}{l}\text { Adults } \\
\text { (Arabic, } \\
\text { Japanese, } \\
\text { Persian and } \\
\text { Spanish) }\end{array}$ & $\begin{array}{l}\text { Child } \\
\text { (Japanese) }\end{array}$ & $\begin{array}{l}\text { Children, } \\
\text { Adolescents, } \\
\text { Adults } \\
\text { (Spanish) }\end{array}$ \\
\hline $\mathrm{N}=3$ & $\mathrm{~N}=21$ & $\begin{array}{l}\mathrm{N}=60 \text { Span. } \\
55 \text { Chin. }\end{array}$ & $\mathrm{N}=73$ & $\mathrm{~N}=24$ & $\mathrm{~N}=1$ & $\mathrm{~N}=6$ \\
\hline $\begin{array}{ll}1 & \text { Pres. } \\
& \text { Prog. }\end{array}$ & $\begin{array}{ll}2 & \text { Pres. } \\
& \text { Prog. }\end{array}$ & $\begin{array}{ll}1 & \text { Art. }\end{array}$ & $\begin{array}{ll}1 & \text { Pres. } \\
& \text { Prog. }\end{array}$ & $\begin{array}{ll}1 & \text { Pres. } \\
& \text { Prog. }\end{array}$ & $\begin{array}{ll}1 & \text { Pres. } \\
& \text { Prog. }\end{array}$ & $\begin{array}{ll}1 & \text { Pres. } \\
& \text { Prog. }\end{array}$ \\
\hline 2.5 on & 2 Plural & 2 Copula & $2 \quad$ Plural & 2 Copula & 2 Copula & 2 \\
\hline 2.5 in & on & 3 Prog. & $\begin{array}{ll}3 & \text { Contr. } \\
& \text { Cop. }\end{array}$ & $\begin{array}{ll}3 & \text { Art. }\end{array}$ & $2 \quad$ Aux & 3 \\
\hline $4 \quad$ Plural & 4 in & $\begin{array}{ll}4 & \text { Simple } \\
& \text { Plural }\end{array}$ & $4 \quad$ Art. & $4 \quad$ Aux. & 4.5 in & $\begin{array}{ll}4 & \text { Art. }\end{array}$ \\
\hline $\begin{array}{ll}5 & \text { Past } \\
& \text { Irreg. } \\
\end{array}$ & $\begin{array}{ll}5 & \text { Past } \\
& \text { Irreg. } \\
\end{array}$ & $\begin{array}{ll}5 & \text { Aux. }\end{array}$ & $\begin{array}{ll}5 & \text { Past } \\
& \text { Irreg. } \\
\end{array}$ & $\begin{array}{ll}5 & \text { Short } \\
& \text { Plural } \\
\end{array}$ & 4.5 to & 5 Cop. \\
\hline $6 \quad$ Poss. & Art. & $\begin{array}{ll}6 & \text { Past } \\
& \text { Reg. }\end{array}$ & 6 Poss. & $\begin{array}{ll}6 & \text { Past } \\
& \text { Reg. }\end{array}$ & $\begin{array}{ll}6 & \text { Past } \\
& \text { Aux. }\end{array}$ & $\begin{array}{ll}6 & \text { Aux }\end{array}$ \\
\hline $\begin{array}{ll}7 & \begin{array}{l}\text { Uncon. } \\
\text { Cop. }\end{array}\end{array}$ & 7 Poss. & $\begin{array}{ll}7 & \text { Past } \\
& \text { Irreg. }\end{array}$ & $\begin{array}{ll}7 & \text { Contr. } \\
& \text { Aux. }\end{array}$ & $\begin{array}{ll}7 & \text { Sing }\end{array}$ & 7 on & $\begin{array}{ll}7 & \text { Poss. }\end{array}$ \\
\hline 8 Art. & $\begin{array}{c}8.53^{\text {rd }} \text { Pers. } \\
\text { Irreg. }\end{array}$ & $\begin{array}{ll}8 & \text { Long. } \\
& \text { Plural }\end{array}$ & $\begin{array}{ll}8 & 3^{\text {rd }} \text { Pers. } \\
& \text { Pres. }\end{array}$ & $\begin{array}{ll}8 & \text { Past } \\
& \text { Irreg. }\end{array}$ & $\begin{array}{ll}8 & \text { Poss. }\end{array}$ & $\begin{array}{ll}8 & \text { Past. } \\
& \text { Irreg. }\end{array}$ \\
\hline $\begin{array}{ll}9 & \text { Past } \\
& \text { Reg. }\end{array}$ & $\begin{array}{l}8.5 \text { Contr. } \\
\text { Cop. }\end{array}$ & 9 Poss. & & $\begin{array}{ll}9 & \text { Long } \\
& \text { Plural }\end{array}$ & $\begin{array}{ll}9 & \text { Past } \\
& \text { Irreg. }\end{array}$ & $\begin{array}{ll}9 & \text { Long } \\
& \text { Plural }\end{array}$ \\
\hline $\begin{array}{c}103^{\text {rd }} \text { Pers. } \\
\text { Reg. }\end{array}$ & $\begin{array}{c}\text { 10.5 Contr. } \\
\text { Cop }\end{array}$ & $3^{\text {rd }}$ Pers & Sing. & 10 Poss & 10 Plural & $\begin{array}{ll}10 & \text { Past } \\
& \text { Reg. }\end{array}$ \\
\hline $\begin{array}{c}113^{\text {rd }} \text { Pers. } \\
\text { Irreg. }\end{array}$ & $\begin{array}{r}10.5 \text { Past } \\
\text { Reg. }\end{array}$ & & & & 11 Art & $\begin{array}{ll}11 & 3^{\text {rd }} \text { Pers. } \\
& \text { Reg }\end{array}$ \\
\hline $\begin{array}{l}12 \text { Uncontr. } \\
\text { Aux. }\end{array}$ & $\begin{array}{l}12 \text { Uncontr. } \\
\text { Cop. }\end{array}$ & & & & $\begin{array}{l}123^{\text {rd }} \text { Pers. } \\
\text { Reg }\end{array}$ & \\
\hline $\begin{array}{l}13 \text { Contr. } \\
\text { Cop. }\end{array}$ & $\begin{array}{l}13 \text { Contr. } \\
\text { Cop. }\end{array}$ & & & & $\begin{array}{c}13 \text { Past } \\
\text { Reg. }\end{array}$ & \\
\hline $\begin{array}{c}14 \text { Contr. } \\
\text { Aux. }\end{array}$ & $\begin{array}{l}14 \text { Uncontr. } \\
\text { Aux. }\end{array}$ & & & & $\begin{array}{c}14 \text { Gonna } \\
\text { Aux. }\end{array}$ & \\
\hline
\end{tabular}

I am going to focus on three of them, those which have shaped Second Language Acquisition studies since then, Child L1 studies (by Brown), Child L2 studies (by Dulay and Burt) and Adult L2 studies (by Bailey, Madden \& Krashen).

${ }^{2}$ Adapted from Jeong, 2002. Abbreviations are as follows: Pres. Prog., Present Progressive; Art., Article; Contr. Cop., Contracted Copula; Aux., Auxiliary; Past Irreg., Past Irregular; Poss., Possessive; Past Reg., Past Regular; Uncontr. Cop., Uncontracted Copula; Sing., Singular; $3^{\text {rd }}$ Pers. Sing., and $3^{\text {rd }}$ Person Singular. Note that rank order numbers that repeat within a given column (study) indicate a tie for two or more positions, in which case an average point score is assigned to each morpheme. Thus, for example, in a tie for $2^{\text {nd }}$ and $3^{\text {rd }}$ (Brown, 1973), each morpheme is a given rank score of 2.5 . 
The history of MOS can be traced to R. Brown's (1973) study. In his study he dealt with the order of acquisition of certain morphemes known also as functors ${ }^{3}$ solely from the perspective of first language (L1) acquisition (Kwon 2005, p.2). Although Brown's study does not refer to second language acquisition, it was still crucial for the development of SLA.

Brown's aim was to investigate about the order of acquisition of inflectional morphology in English because he wanted to "demonstrate that second language acquisition was not just a matter of learned response but that individuals developed second language competence according to a predictable series of benchmarks." (Kwon 2005, p. 2). In order to do so, he analyzed the speech of three subjects (Adam, Sarah and Eve who were native speakers of American English) up to age of 4 collected over time ${ }^{4}$ (He recorded 2 hours of speech monthly). The conclusion was that they all had the same route (order) but different rate (speed) and that there was no correlation between order and input. In other words, the fact you use a certain mistake more frequently does not mean that it would be acquired earlier.

Another major contribution of Brown's study to the MO studies in general, regards Brown's methodology. Brown's analysis became a model for scoring and comparing data on functor acquisition order. As reported in Kwon $(2005$, p. 3) Brown observed that when the data were represented graphically, the curve of accuracy for a particular functor was initially chaotic, but that once that curve had passed above the $90 \%$ line several consecutive samples it tended to remain above that line. As a result, Brown set his cutoff point for acquisition at $90 \%$ of accuracy.

Finally it is important to highlight the notion of suppliance in obligatory context (SOC) that is explained by Brown as follows:

...grammatical morphemes are obligatory in certain context, and so one can set an acquisition criterion not simply in terms of output, but in terms of output- where-required. Each obligatory context can be regarded as a kind of test item which the child passes by supplying the required morpheme or fails by supplying none or one that is not correct. This performance measure, the percentage of morphemes supplied in obligatory contexts, should not be dependent on the topic of conversation or the character of the interaction (1973, p 225).

Table 3 shows the 14 functors isolated by Brown in the acquisition order demonstrated by the three American native speakers in his longitudinal study.

\footnotetext{
${ }^{3}$ R. Brown (1973) defines functors as "forms that do not, in any simple way, make reference." They mark grammatical structures and carry subtle modulatory meanings.

${ }^{4}$ Data for two of the children were collected over five-year period beginning at age 27 months. Dta for the third child was collected over a one-year period beginning at age of 18 months.
} 
Table 3. Order of L1 Acquisition of English Morphemes in R. Brown (1973)

\begin{tabular}{|l|l|}
\hline Rank & Morpheme \\
\hline 1 & Present Progressive $(-$-ing $)$ \\
\hline $2 / 3$ & in, on \\
\hline 4 & Plural $(-s)$ \\
\hline 5 & Past irregular \\
\hline 6 & Possessive $(-$ s) \\
\hline 7 & Uncontractible copula (is, am, are $)$ \\
\hline 8 & Articles $(a$, the $)$ \\
\hline 9 & Past regular $(-e d)$ \\
\hline 10 & Third person singular $(-s)$ \\
\hline 11 & Third person irregular \\
\hline 12 & Uncontractible auxiliary $($ is, am, are $)$ \\
\hline 13 & Contractible copula \\
\hline 14 & Contractible auxiliary \\
\hline
\end{tabular}

Once we have discussed Brown 's study we are going to focus on Dulay \& Burt 's research. In 1973 these authors found a consistent order across three groups of L1 Spanish child learners of English (Dulay \& Burt 1973); therefore they considered the possibility that Brown's morpheme order acquisition could be also applied to second language learners and in 1974 they expanded their research. The aim of the first study was to investigate if there was a natural order in child L2 English and if it was similar to fist language acquisition. In order to find answers, they worked with three groups of subjects of 5-8-year-old L1 Spanish speakers in the US, acquiring English as an L2. These three groups worked under different conditions; the first group ( $n=30$ ) was Puerto Rican children in New York. They had been immersed in English for less than a year and they attended a bilingual English/Spanish school but they had no formal training in English as a Second Language; the second group $(n=95)$ was mostly US-born children of Spanish-speaking parents. They had ESL classes and their school curriculum was in English; the third group $(n=26)$ was composed by Mexican children from Tijuana who crossed the border to attend to an English medium school every day, but returned to Mexico every afternoon.

Their method was based on a series of cartoons each with an associated question to elicit utterances from the informants containing the morphemes in question.

The grammatical morphemes Dulay and Burt investigated in their first study were ${ }^{5}$ :

\footnotetext{
${ }^{5}$ Dulay, H and Burt, M. 1973: Should we teach children syntax? Language Learning 23, 245-258. Haspelmath, M. 2002: Understanding morphology. London: Arnold
} 
Table 4. Grammatical morphemes studies by Dulay and Burt (1973)

\begin{tabular}{|c|c|}
\hline Progressive -ing & She's read-ing \\
\hline Plural $-\mathrm{s}$ & Book-s \\
\hline Irregular past tense & She ran \\
\hline Possessive & Kim-'s book \\
\hline Article (a, the) & a/the book \\
\hline 3 pers sing pres & She read-s every evening \\
\hline Copula (contractible) & She's happy/a doctor \\
\hline Auxiliary (contractible) & She-'s reading \\
\hline
\end{tabular}

Those grammatical morphemes were scoring as follows:

- They gave each subject a score of 1 if they had supplied the morpheme correctly in a obligatory context,

- A 0.5 was given if they had supplied a morpheme, but a wrong one.

- A score of 0 was given if there was no morpheme supplied.

As we can see in table number 4 the level of accuracy was high on some morphemes, but low in others. Hence, the results suggested that the morpheme acquisition order, which their L2 subjects followed, was displayed a route similar to the one found in Brown's (1973) list.

$\underline{\text { High }}$

Article

Progressive -ing

Copula be

Plural-s
Low

Irregular past

Possessive

3 rd person -s 
One year later, in 1974 Dulay and Burt expanded their first study; their subjects were 6-8-year-old children learning English as an L2 in USA. Those groups were composed by 60 Spanish and 55 Chinese. The aim of the study was to explore if L1 influences the acquisition of morphemes using the BSM (bilingual syntax measure), that is to say, they gave children a picture and asked them a question waiting for an expected answer.

Table 5. Results from Dulay and Burt (1974)

\begin{tabular}{|c|l|}
\hline Order & \multicolumn{1}{|c|}{ Morpheme } \\
\hline 1 & Plural '-s' \\
\hline 2 & Present progressive '-ing' \\
\hline 3 & Copula 'Be' \\
\hline 4 & Auxiliary 'Be' \\
\hline 5 & Articles \\
\hline 6 & Past Irregular \\
\hline 7 & Third person singular '-s' \\
\hline
\end{tabular}

The results showed that, both groups supplied morphemes with a similar frequency, "some morphemes are more "difficult" than others". As it can be observed in table ... there was a similar developmental profile despite the participants' mother tongue. Therefore the $L 1$ is not relevant in the acquisition of grammatical morphemes.

The last study we are going to discuss is Bailey, Madden and Krashen's (1974) research. This study is dedicated to the natural order displayed in L2 English adult learners' language. The aim of this study was to explore if the "natural order" found in L2 child learners is similar for adult 2L English learners. 73 subjects took part in this study; 33 Spanish natives and 40 other adults with different L1s: Greek, Persian, Turkish, Thai... etc. The method these researchers used was the BSM, the same one that Dulay and Burt used in previous studies. The result of this study was that there was a similar developmental pattern in both groups. The sequence they found in adults $L 2$ was the following one: 
Figure 1. Sequence found in adults L2. Dulay \& Burt (1974)

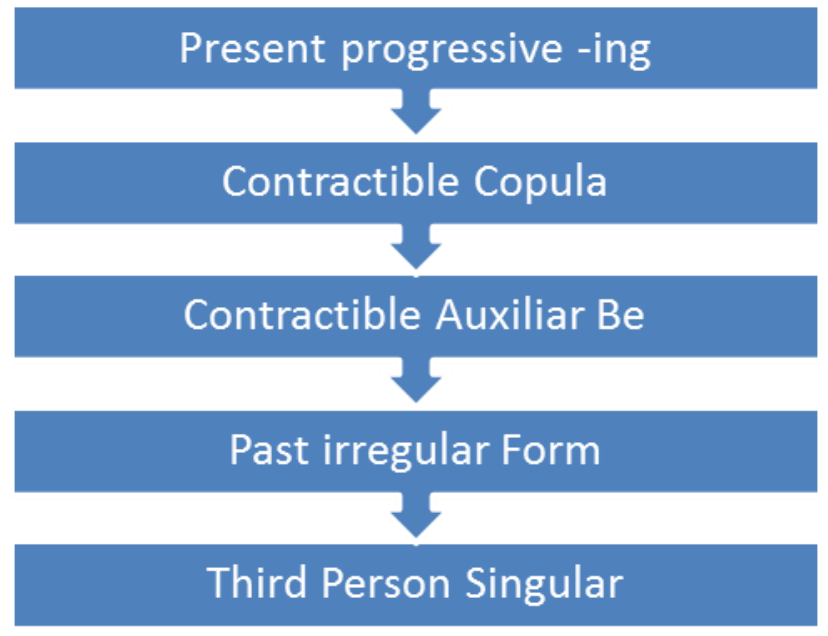

Table 6. Results from Bailey, Madden and Krashen (1974).

\begin{tabular}{|c|l|}
\hline Order & \multicolumn{1}{c|}{ Morpheme } \\
\hline 1 & Present Progressive '-ing' \\
\hline 2 & Copula 'Be' \\
\hline 3 & Plural' \\
\hline 4 & Articles \\
\hline 5 & Auxiliary 'Be' \\
\hline 6 & Past Irregular \\
\hline 7 & Third person singular '-s' \\
\hline 8 & Possessive 's \\
\hline
\end{tabular}

Several studies have been written about factors may influence morpheme order acquisition (LarsenFreeman, 1976), (Muñoz, 2006). The most common variables are age and L1 background. However some other factors such as morphological regularity, frequency, semantic complexity, native language language transfer... etc were also discussed.

As we can find in Ellis (2005) one of the most relevant study is Godschneider \& DeKeyser (2001) where these authors proposed five determinants that account for the natural order hypothesis: i) perceptual salience, ii) semantic complexity, iii) morphological regularity, iv) syntactic category and v) frequency.

i. Perceptual salience. The more perceptually salient morpheme is the earlier acquired. For instance, we acquire the morpheme -ing earlier because it is easier to hear than for example the $3 P-s$. 
ii. Semantic complexity. The more meanings a form expresses the more difficult it will be acquired, for instance the morpheme -s expresses number, present tense and plural, therefore it is one of the most difficult morphemes to be acquired.

iii. Morphological regularity. Morphemes which are phonologically simple are easier to be acquired. For instance, the indefinite article $a(n)$ is more regular than the plural morpheme $-\mathrm{s}$ because the latter one has three different realizations $[s],[z]$ and $[i z]$

iv. Syntactic category. Lexical morphemes are acquired earlier than grammatical ones. For instance, the morpheme -ment (lexical) would be acquired earlier than the morpheme a $(n)$ (grammatical)

v. Frequency. Morphemes which are frequent in the input are easier to be acquired. For instance the definite article the is commoner than the -ed participle.

It is important to highlight that this study has been criticized for three main reasons:

I. The five variables can be included in the sense of salience.

II. The perceptual salience determinant requires a theory of perception.

III. It was proved that input does not alter the morpheme order acquisition (Goldschneider \& DeKeyser, 2001, pp. 35-37).

\subsection{Learner corpora and learner corpus research}

To start with the term Linguistic Corpora could be defined as a large collection of texts, written or spoken, presented in digital form that are to be representative of a given language and that are to be used for linguistic analysis. The main purpose of corpora, according to Corpus Linguistics, is using those samples for linguistic analysis. Therefore, Corpus Linguistics is not a linguistic discipline as such but a methodology that uses language Corpora for the descriptive study of language.

Although a large corpora have emerged: British Nation Corpus (BNC, 100 million) the Bank of English (450 million), the International Corpus of English (ICE 20 million) and getting familiar with them is easier because we can access via the Web we still find several problems when we use them as a methodological tool because as McEnery and Wilson (2001) pointed out corpora are a type of data which were originally designed for the purposes of linguistic research and it design is not that easy for students and teachers. As we can read in this article, there are two ideas we have to take into account if we want 
to study corpora as a teaching method: size and content. According to Braun "the sheer size of many available corpora and the nature of their content make them difficult to handle for most teachers and learners". Therefore if we use a large corpus we are going to have too many results and as Menuier (2002: 129) points out corpus result can be "messy".

Moreover, If we talk about linguistic corpora and their methods we cannot forget what DataDriven Language is. It is a methodology which explains grammar aspects throughout real examples. This method uses the inductive teaching, it provides a list of examples where we can find a particular structure and we can study it paying attention to the pattern. This method uses authentic material because we need real structures in order to identify the patterns; therefore the student is exposed to the English language (Meyer, 2009).

Although Corpora were originally used for linguistic description they are now used in other applied areas language teaching. Among those new forms of using Corpora we can find Learner Corpora which is a dynamic branch of corpus linguistics. It began to emerge as a discipline in its own right in the late 1980's/early 1990's . It can be defined as follows (Granger 2008, p.259):

'electronic collections of texts produced by language learners which have been used to fulfil two distinct, though related, functions: they can contribute to SLA theory by providing a better description of interlanguage and a better understanding of the factors that influence it; and they can be used to develop pedagogical tools and methods that more accurately target the needs of language learners.'

As we can read in Braun (2005), the insights into language use which corpora offer seem to leave no doubt that they hold great potential both as a resource for the creation of rich and interesting learning materials and for direct exploitation by learners. According to him the data corpora provide is ${ }^{6}$ :

- authentic (showing language in real use);

- $\quad$ rich (providing more information than dictionaries);

- illustrative (providing actual patterns of use instead of abstract explanations);

- up to date.

According to Granger (2004, pp. 124-127) there are some specific features that makes learner corpora different to the rest of corpora. They will be explained as follows:

\footnotetext{
${ }^{6}$ Braun (2005, p.48)
} 
I. Size. The fact that data is stored electronically makes possible to work with a large amount of corpora, although she also pointed that the larger does not mean to be the better. (it was be reliable only if the criteria to design corpus have been followed strictly )

II. Variability. There are certain variables that influence language learner. Some of them are linguistic, situational and psycholinguistic nature. For instance, age, genre, mother tongue, region, etc...

III. Automation. The fact that corpus are electronic facilitates the collection and the analysis of the data.

Some time later (Granger 2008) she described a series of dimensions that also characterize learner corpora:

I. Commercial vs. academic. The first one were initiated by major publishing companies and the latter one were compiled in educational settings. For English the two major commercial corpora are the Longman Learners' Corpus and the Cambridge Learner Corpus. As an example of academic corpora we have the International Corpus of Learner English (ICLE).

II. Big vs. small. The fact that data is stored electronically makes possible to work with a large amount of corpora. However small corpora are also of considerable value. As pointed by Ragan (2001: 211) "the size of the sample is less important that the preparation and tailoring of the language product and its subsequent corpus application $\mathrm{t}$ to draw attention to an individual or group profile of learner language use" as it was said before size is only useful the criteria to design corpus have been followed strictly.

III. English vs. non-English. We can find some samples of non-English corpora; the CEDEL210 (A Spanish learner corpus) or the FLLOC (a French learner copus) however English plays the most important role when we talk about the learner corpus scene. For instance, the British Nation Corpus (BNC, 100 million) the Bank of English (450 million), or the International Corpus of English (ICE 20 million).

IV. Writing vs. speech. The written corpora dominate the corpus scene. One of the reasons could be that the collection and transcription of the speech is multiplied by a factor of 10 in the case of learner data. 
V. Longitudinal vs. cross-sectional. This dimension has to do with the time data were collected. Cross-sectional corpora retrieve data from a single point in time while Longitudinal corpora require collecting data from the same individuals over time, so they are usually more difficult to collect.

VI. Immediate vs. delayed pedagogical use. LC could be used to obtain information about students' interlanguage and to create pedagogical tools. This definition matches with the immediate use. On the other hand the delayed pedagogical use is used to compile corpora.

According to Tono $(2003: 800)$ there are three main design considerations for building learner corpora: language-related, task-related and learner-related.

Table 7. Learner Corpus design variables. Tono (2003: 800).

\begin{tabular}{lll}
\hline Types of feature & & \\
language-related & task-related & learner-related \\
\hline mode & data collection & internal-cognitive \\
[written/spoken] & [cross-sectional/ongitudinal] & [age/cognitive style] \\
genre & elicitation & internal-affective \\
[letter/diary/fiction/essay] & [spontaneous/prepared] & [motivation/attitude] \\
style & use of references & L1 background \\
[narration/argumentation] & [dictionary/source text] & L2 environment \\
topic & time limitation & [ESL/FFL] [level of school] \\
[general/leisure/ etc] & [fixed/free/homework] & L2 proficiency \\
& & [standard test score] \\
\hline
\end{tabular}

According to Granger (2008:266-270) there are two types of learner corpus analysis:

i. Contrastive interlanguage analysis. $(\mathrm{CIA})$ : this methodology involves learner data with native speaker data (L2 vs. L1) or comparing different types of learner data (Granger 1996).

The aim of this type of analysis is to discover the use of the most frequent vocabulary, modal verbs, connectors, etc. So, $\mathrm{ClA}$ is useful in order to highlight grammatical items, syntactic structures or simply words that are over or underused by learners.

ii. Computer-aided error analysis. (CEA) tries to analyze "learners errors on the basis of LC in which error tags and possible corrections have been inserted with the help of a purpose-built editing tool" (Granger 2008:268). This method is different from other error analysis systems since errors are not isolated from the original texts; in other words, learner's errors are studied in context. 
Finally I would like to share a table which is shown In Tono 2008 ( $p$ 802) which summarizes the major corpus projects until 2008 . We can see that this field is rapidly growing.

Table 8. Learner corpus projects around the world. Tono (2008)

\begin{tabular}{|c|c|c|c|c|}
\hline Project & $\begin{array}{l}\text { Subjects/ } \\
\text { Tasks Size }\end{array}$ & $\begin{array}{l}\text { Annotation } \\
\text { Availability }\end{array}$ & Comparison & References \\
\hline \multicolumn{5}{|c|}{ Europe: } \\
\hline $\begin{array}{c}\text { International } \\
\text { Corpus of } \\
\text { Learner } \\
\text { English (ICLE) }\end{array}$ & $\begin{array}{c}\text { - University EFL } \\
\text { 3/4 year students } \\
\text { - } 15 \text { nationalities } \\
\text { - Written essays } \\
\text { - } 3 \text { million }\end{array}$ & $\begin{array}{l}\text { - Error } \\
\text { tagged } \\
\text { - POS tagged } \\
\text { - Available } \\
\text { in } 2002 \\
\end{array}$ & $\begin{array}{c}-\mathrm{IL}-\mathrm{IL} \\
\text { (different L1s) } \\
-\mathrm{TL}-\mathrm{IL}\end{array}$ & $\begin{array}{l}\text { Granger } \\
(1993 ; 1994 ; \\
\text { 1996; 1998b; } \\
2002)\end{array}$ \\
\hline $\begin{array}{c}\text { LINDSEI } \\
\text { (Louvain } \\
\text { International } \\
\text { Database of Spoken } \\
\text { English } \\
\text { Interlanguage) }\end{array}$ & $\begin{array}{c}\text { - } 50 \text { interviews } \\
\text { - University EFL } \\
3 / 4 \text { year students } \\
\text { - 100,000 words } \\
\text { - CH/IT/FR/JP }\end{array}$ & $\begin{array}{c}- \\
\text { orthographic }\end{array}$ & $\begin{array}{c}-\mathrm{IL}-\mathrm{IL} \\
\text { (different L1s) }\end{array}$ & $\begin{array}{l}\text { Granger } \\
(2001)\end{array}$ \\
\hline \begin{tabular}{l}
\multicolumn{1}{c}{ Longman } \\
Learners' \\
Corpus (LLC)
\end{tabular} & $\begin{array}{l}\text { - All-levels } \\
\text { - Written essays } \\
\text { - } 10 \text { million }\end{array}$ & $\begin{array}{l}\text { - POS tagged } \\
\text { - Available for } \\
\text { commercial } \\
\text { purposes }\end{array}$ & - IL - IL & $\begin{array}{r}\text { Gillard and } \\
\text { Gadsby (1998) }\end{array}$ \\
\hline $\begin{array}{c}\text { Polish-English } \\
\text { Language Corpus } \\
\text { Research and } \\
\text { Applications } \\
\text { (PELCRA) }\end{array}$ & $\begin{array}{l}\text { - All-levels } \\
\text { - Written/spoken } \\
\text { essays } \\
\text { - Polish learners }\end{array}$ & $\begin{array}{l}\text { - POS tagged } \\
\text { - Not } \\
\text { available }\end{array}$ & $\begin{array}{c}-\mathrm{IL}-\mathrm{IL} \\
\text { (developmental) } \\
\text { - L1 - IL } \\
\text { - TL - IL }\end{array}$ & $\begin{array}{c}\text { Uzar (1997) } \\
\text { Mason \& } \\
\text { Uzar (2000) }\end{array}$ \\
\hline $\begin{array}{l}\text { The UAM } \\
\text { Corpus }\end{array}$ & $\begin{array}{c}\text { Corpus of } \\
\text { teacher and students } \\
\text { production data. }\end{array}$ & & $\begin{array}{c}\text { IL-IL } \\
\text { longitudinal }\end{array}$ & $\begin{array}{r}\text { Garcia (in } \\
\text { this workshop) }\end{array}$ \\
\hline $\begin{array}{l}\text { The ISLE } \\
\text { Corpus of non- } \\
\text { native spoken } \\
\text { English }\end{array}$ & $\begin{array}{c}\text { - } 20 \text { minute } \\
\text { speech } \\
\text { - German \& Italian } \\
\text { intermediate learners of } \\
\text { English }\end{array}$ & $\begin{array}{c}- \\
\text { Orthographic } \\
\text { - Phone- } \\
\text { stress } \\
\text { - Available } \\
\text { from ELRA } \\
\end{array}$ & - TL - IL & $\begin{array}{c}\text { http://nats- } \\
\text { www.informatik.u } \\
\text { ni- } \\
\text { hamburg.de/ isle/s } \\
\text { peech.html }\end{array}$ \\
\hline $\begin{array}{c}\text { JPU (Janus } \\
\text { Pannonius } \\
\text { University) Corpus }\end{array}$ & $\begin{array}{c}\text { - University EFL } \\
\text { - Written } \\
\text { - c. } 400,000\end{array}$ & $\begin{array}{l}\text { - Plain text } \\
\text { - Will be } \\
\text { available }\end{array}$ & $\begin{array}{c}-\mathrm{IL}-\mathrm{IL} \\
\text { (developmental) }\end{array}$ & József (1998) \\
\hline $\begin{array}{l}\text { Cambridge } \\
\text { Learners } \\
\text { Corpus (CLC) }\end{array}$ & $\begin{array}{l}\text { - All-levels } \\
\text { - } 10 \text { million }\end{array}$ & $\begin{array}{l}\text { - POS tagged } \\
\text { - Error- } \\
\text { tagged ( } 2.5 \\
\text { million) } \\
\text { - In-house use } \\
\text { only }\end{array}$ & - IL - IL & $\begin{array}{l}\text { http://uk.cam } \\
\text { bridge.org/elt/refer } \\
\text { ence/clc.htm }\end{array}$ \\
\hline $\begin{array}{c}\text { Indianapolis } \\
\text { Business } \\
\text { Learner } \\
\text { Corpus (IBLC) }\end{array}$ & $\begin{array}{c}\text { - US univ. } \\
\text { business } \\
\text { students - } \\
\text { business writing } \\
\text { - plain text }\end{array}$ & $\begin{array}{l}\text { - Plain text } \\
\text { - Not } \\
\text { available }\end{array}$ & $\begin{array}{r}-\mathrm{IL}-\mathrm{IL} \\
\text { (different L1s) }\end{array}$ & $\begin{array}{r}\text { Connor \& } \\
\text { Precht (1998) }\end{array}$ \\
\hline
\end{tabular}


Table 9 (continued)

\begin{tabular}{|c|c|c|c|c|}
\hline Project & $\begin{array}{l}\text { Subjects/ } \\
\text { Tasks } \\
\text { Size }\end{array}$ & $\begin{array}{l}\text { Annotation } \\
\text { Availability }\end{array}$ & Comparison & References \\
\hline \multicolumn{5}{|l|}{ ASIA: } \\
\hline $\begin{array}{l}\text { JEFLL Corpus } \\
\text { (Japan) }\end{array}$ & $\begin{array}{l}\text { - All levels; } \\
\text { EFL } \\
\text { - Written \& } \\
\text { spoken } \\
\quad-1 \text { million } \\
\text { (expected in 2004) }\end{array}$ & $\begin{array}{l}\text { - POS-tagged } \\
\text { - Error-tagged } \\
\text { (partial) } \\
\text { - Will be } \\
\text { available }\end{array}$ & $\begin{array}{l}\text { - IL - IL } \\
\text { cross-sectional } \\
\text { - L1 - IL } \\
\text { - TL - IL }\end{array}$ & $\begin{array}{l}\text { Tono (2000a, } \\
\text { b) } \\
\text { Tono and } \\
\text { Aoki (1998) } \\
\text { Tono (2002) }\end{array}$ \\
\hline $\begin{array}{l}\text { Corpus of } \\
\text { English } \\
\text { by Japanese } \\
\text { Learners }\end{array}$ & $\begin{array}{cl}\text { EFL } & \text { - All levels; } \\
& - \text { Written } \\
& -1 \text { million }\end{array}$ & $\begin{array}{l}\text { - Plain text } \\
\text { - Error tagged } \\
\text { (partial) } \\
\text { - Will be } \\
\text { available }\end{array}$ & $\begin{array}{l}\text { - IL - IL } \\
\text { cross-sectional }\end{array}$ & Asao (1998) \\
\hline $\begin{array}{l}\text { Japanese/ } \\
\text { English } \\
\text { Translation } \\
\text { corpus }\end{array}$ & $\begin{array}{l}\quad \text { - junior \& } \\
\text { senior high EFL } \\
\text { students } \\
\quad \text { - L1/L2 } \\
\text { translation }\end{array}$ & $\begin{array}{l}\text { - Plain text } \\
\text { - Available via } \\
\text { the web }\end{array}$ & $-\mathrm{TL}-\mathrm{IL}$ & $\begin{array}{l}\text { http://home.hir } \\
\text { oshima- } \\
\text { u.ac.jp/d052121/eig } \\
\text { o1.html }\end{array}$ \\
\hline $\begin{array}{l}\quad \text { Standard } \\
\text { Speaking Test } \\
\text { (SST) Corpus (also } \\
\text { called the TAO } \\
\text { Corpus) }\end{array}$ & $\begin{array}{l}\text { - All levels; } \\
\text { EFL } \\
\text { - Spoken } \\
-1,000,000 \\
\quad-15 \text { min } \\
\text { interview }\end{array}$ & $\begin{array}{l}\text { - Error tagged } \\
\text { (partial) } \\
\text { - Will be } \\
\text { available }\end{array}$ & $\begin{array}{l}\text { - IL-IL } \\
\text { (developmenta }\end{array}$ & $\begin{array}{l}\text { Tono et al. } \\
\text { (2001) }\end{array}$ \\
\hline $\begin{array}{c}\text { TELEC } \\
\text { Student Corpus }\end{array}$ & $\begin{array}{l}\text { - Hong Kong } \\
\text { learners } \\
\text { - Univ. exam } \\
\text { scripts } \\
\text { - } 3 \text { million }\end{array}$ & $\begin{array}{l}\text { - Plain text } \\
\text { - Restricted } \\
\text { availability }\end{array}$ & $-\mathrm{TL}-\mathrm{IL}$ & Allan (1998) \\
\hline Poly U Corpus & $\begin{array}{l}\text { - } \\
\text { Postgraduates } \\
\quad \text { - thesis drafts, } \\
\text { etc. } \\
\quad-282,000\end{array}$ & - Plain text & $-\mathrm{TL}-\mathrm{IL}$ & $\begin{array}{l}\text { Farmer and } \\
\text { Mead (1998) }\end{array}$ \\
\hline NTOU Corpus & $\begin{array}{l}-\mathrm{EFL} \\
-53,000\end{array}$ & - Plain text & $\begin{array}{l}-\mathrm{TL}-\mathrm{IL} \\
-\mathrm{IL}-\mathrm{IL}\end{array}$ & Chen (1998) \\
\hline $\begin{array}{c}\text { A parallel } \\
\text { corpus of Japanese } \\
\text { learners of English }\end{array}$ & $\begin{array}{l}\quad \text { - Short } \\
\text { English } \\
\text { compositions } \\
\quad \text { - Paired with } \\
\text { Japanese } \\
\text { translations \& NS's } \\
\text { rewritings }\end{array}$ & $\begin{array}{cc}- & \text { Database } \\
\text { format } & \end{array}$ & $\begin{array}{l}-\mathrm{TL}-\mathrm{IL} \\
-\mathrm{IL}-\mathrm{L} 1\end{array}$ & b) Mark (1998a, \\
\hline MET Corpus & $\begin{array}{l}\text { - Chinese } \\
\text { middle school } \\
\text { students } \\
\text { - Written } \\
\text { - c. } 150000\end{array}$ & - Plain text & - TL - IL & $\mathrm{He}(1998)$ \\
\hline $\begin{array}{c}\text { HKUST } \\
\text { Corpus of } \\
\text { Learner } \\
\text { English (HKUST) }\end{array}$ & $\begin{array}{l}\text { - } \quad \text { University } \\
\text { EFL } \\
\text { Chinese } \\
\text { students } \\
\text { - } 10 \text { million } \\
-\quad \quad \text { Written } \\
\text { essays \& } \\
\text { exam scripts }\end{array}$ & $\begin{array}{l}\text {-POS tagged } \\
(1 \mathrm{M})^{- \text {Error tagged }} \\
\text { - } \\
(100,000 \text { words })\end{array}$ & $-\mathrm{IL}-\mathrm{IL}$ & $\begin{array}{c}\text { Flowerdew } \\
\text { (1996) } \\
\text { Flowerdew } \\
\text { (1997) } \\
\text { Milton (1998) } \\
\text { Milton and } \\
\text { Tsang (1993) }\end{array}$ \\
\hline
\end{tabular}




\section{Research questions}

As we have seen in the literature review there are several studies based on the morpheme acquisition order. In this study we have tried to replicate those studies in order to answer the following two questions:

- Are our MO study's results similar to the ones suggested by some studies we have reviewed?

- If so, do we usually take that acquisition order into account when we teach English? 


\section{Method}

This section is composed by 4 main stages.

- Participants

- Instruments and materials

- Procedure

- Data coding and analysis.

These stages are the components of the methodology we have used in order to carry out our study.

In the first section information about our participants' background, which is crucial to set our study in a context, will be provided.

We will also describe in detail what instruments and materials we have used to get the information we were looking for.

In the third subsection we will explain how students carried out the task we proposed and finally we will use the last subsection to talk about how we analyzed the data, the transcription and the tagging process.

\subsection{Participants.}

This study was conducted in two Secondary High Schools both of which are state schools. The participants' age ranges from 12 to 19 years old and they were students of either the I.E.S. Cartuja, which is placed in the outskirts of Granada called Granada Norte, or the I.E.S. Santa Catalina de Alejandría, which is placed in a central area in Jaén.

To start with, all participants were Spanish native speakers who have been studying English as a foreign language since they were in the primary school, which indicates that the age of onset (age that the first exposure to EFL took place) in most cases was 6 . The total population was of 77 students.

These two institutions have a different background, which is important to take into account when we study the results we have obtained. The first difference we should highlight is that the students of I.E.S. Santa Catalina were immersed in a Bilingual program, whereas I.E.S Cartuja is a remedial center ${ }^{7}$ due to the area where it belongs and therefore does not offer a bilingual program to its students. The fact that I.E.S Cartuja was a remedial school can be understood as a reason why their students had a lower level of proficiency. They live in an area where social problems abound and that could possibly explain

\footnotetext{
${ }^{7}$ A Secondary High School devoting a graduated teaching to students with learning difficulties.
} 
their lack of motivation, which is an important factor in the acquisition of a foreign language. Therefore, we can affirm that the level of proficiency is quite different in these schools.

The groups where I collected my samples in Cartuja were $2^{\circ}$ ESO and $2^{\circ} B A C$. I collected only 25 samples because in this center each class cannot have more than 20 students. Therefore, the $2{ }^{\circ} E S O$ class was only composed by 14 students; however I just got 10 samples in this class because some of them, 4 students, were studying a different curriculum and their teacher told me they were not able to complete the task I asked for.

1. This group was composed by samples of seven males and three females from 13 and 14 years of age; their proficiency level was $A 1$ in four of them and $A 2$ in six of the cases.

2. The second group, $2^{\circ} B A C$, was a bigger class composed by four males and eleven females from 17 to 19 years of age. Their proficiency level was A2 in nine samples, B1 in four samples to $B 2$ in just two samples.

As I mentioned before, the second institution was I.E.S Santa Catalina de Alejandria, where I took

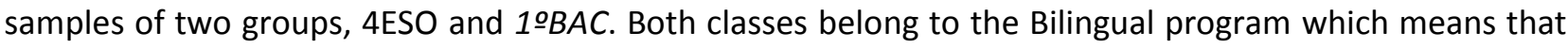
they study several subjects using the English language as a communicative tool ${ }^{8}$

1. The first group, 1ํachillerato was composed by samples of twelve males and seventeen females from 16 to 17 years of age. Nine of them scored B1 in their placement test, 13 of them got a $\mathrm{B} 2$ and the rest, seven of them got a $\mathrm{C} 1$ grade in the exam.

2. The second group, $4^{\circ} E S O$, was composed by 23 students, where we could find twelve males and eleven females from 15 to 16 years of age. Four of them scored $A 2$, sixteen of them scored B1 and finally three of them scored B2.

Table 10 shows the distribution of the subjects according to the institution and the class they belong to, and the proficiency level which has been determined on the basis of the placement test that we applied and which I will explain in the next subsection.

\footnotetext{
${ }^{8}$ Since 2005 Andalusia has a bilingual programme, the regional Minister of Education approved the Plan for the Promotion of Multilingualism. This programme follows the CLIL (Content and Language Integrated Learning) method which is defined as a method which 'involves teaching a curricular subject through the medium of a language other than that normally used. The subject can be entirely unrelated to language learning, such as history lessons being taught in English in a school in Spain. CLIL is taking place and has been found to be effective in all sectors of education from primary through to adult and higher education.' http://ec.europa.eu/languages/languageteaching/content-and-language-integrated-learning en.htm)
} 
Table 10 - Distribution of the subjects according to the institution and class they belong to

\begin{tabular}{|c|c|c|c|c|c|}
\hline & \multicolumn{2}{|c|}{ I.E.S. Santa Catalina } & \multicolumn{2}{c|}{ I.E.S Cartuja } & \multirow{2}{*}{ Total } \\
\cline { 2 - 5 } & 40 ESO & 10 BAC & 20ESO & 29BAC & \\
\hline A1 & - & - & 4 & - & 4 \\
\hline A2 & 4 & - & 6 & 9 & 19 \\
\hline B1 & 16 & 9 & - & 4 & 29 \\
\hline B2 & 3 & 13 & - & 2 & 18 \\
\hline C1 & - & 7 & - & - & 7 \\
\hline C2 & - & - & - & - & - \\
\hline Total & 23 & 29 & 10 & 15 & 77 \\
\hline
\end{tabular}

Figure 2 shows the students' proficiency level according to the class they belong to. Therefore we can see the different levels we find in the same class. Figure 3 shows the distribution of students according to their proficiency level, which is the level we used to classify the different subcorpora. In this figure we can observe the different proficiency levels we found among our subjects taking into account the institution students belong to.

Figure 2 - Number of students by proficiency level according to their class year.

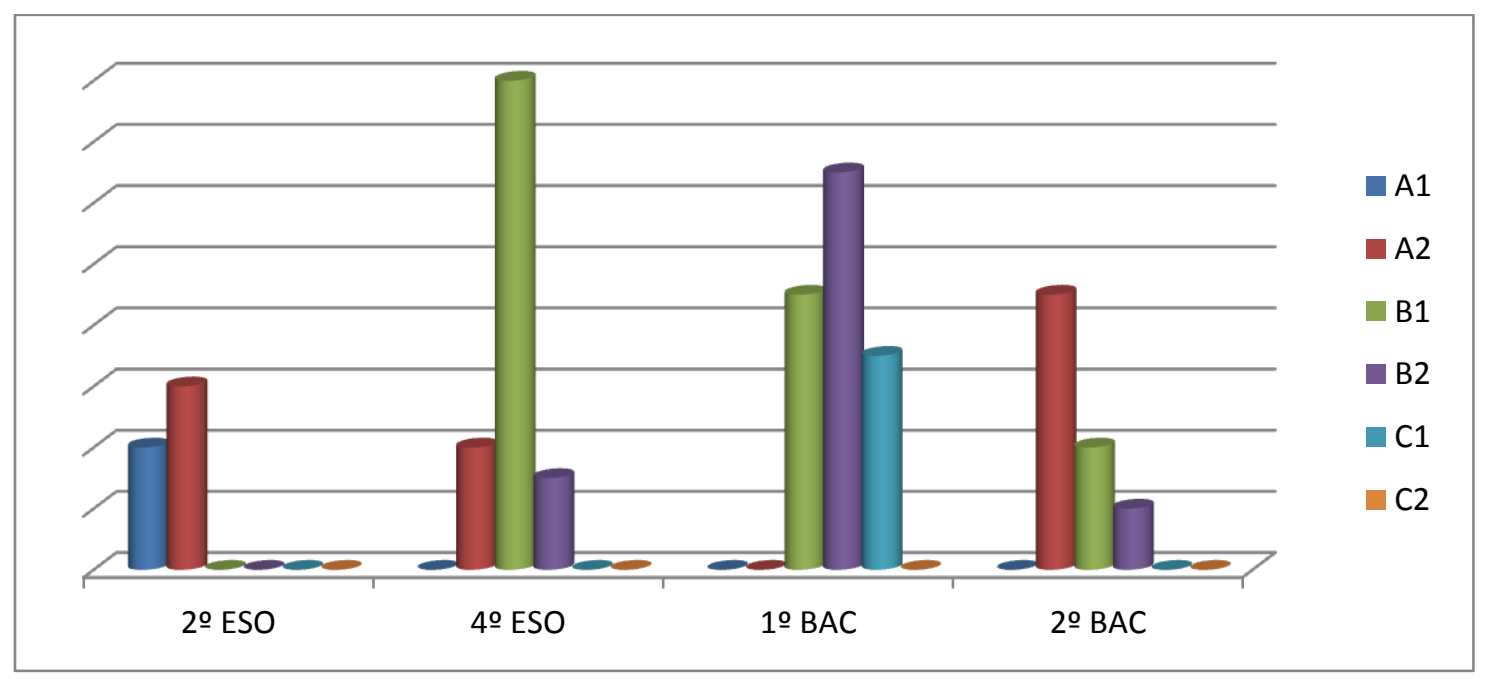


Figure 3 - Students 's proficiency level.

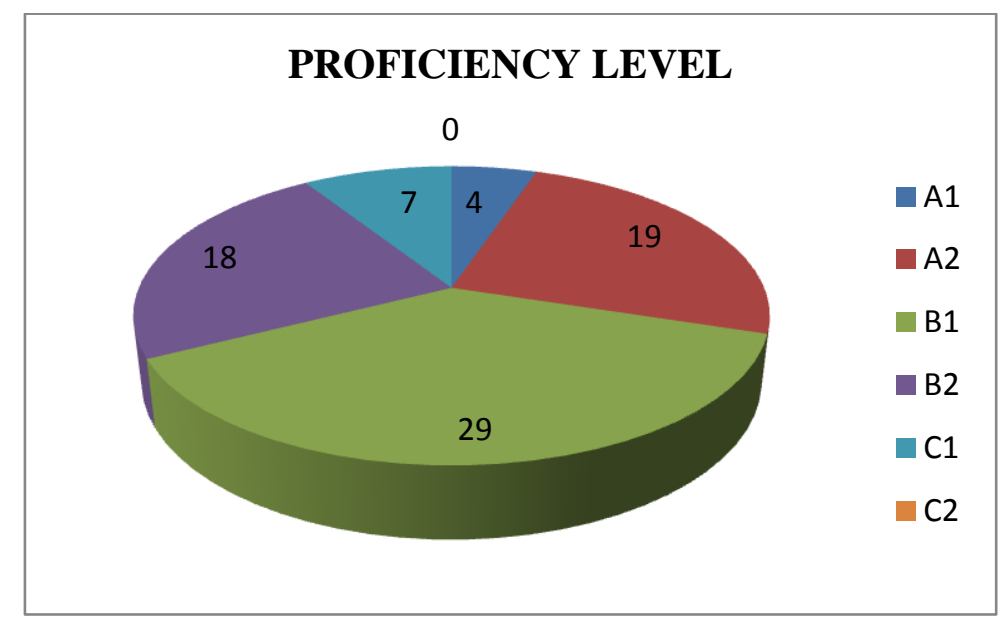

\subsection{Materials and Instruments.}

Four main tools were employed in this study:

- The learner profile form.

- A placement test.

- An elicitation task

- The UAM Corpus Tool.

We will describe how we used them in the following subsection (4.3 Procedure) but first we need to describe each instrument and its usage.

The first instrument we used when we met our participants was the learner profile. This tool was used to collect information about the subjects of our study. The learner profile (see Appendix 1 ) is a form that participants had to fill out; it contains information such as: the age, the gender, the institution they study in, the age of exposure to L2 English, their mother tongue, which level of English they think they have, etc. In order to have a wide range of variables we decided to collect that amount of information because the more variables we had the more precise results we could get. Furthermore, those variables were different among participants and therefore we wanted to take them into account in the analysis of our corpus text. Every piece of information they provided us with was crucial for our study but we have to highlight that one of the most important parts of this learner profile is that participants signed it showing thus that they voluntarily participated in our study. 
After they filled the learner profile out, we asked them to take a placement test. This was compulsory since we needed to know our subjects' proficiency level. When we were at that point we were thinking about using two kinds of placement test but we finally decided that the English Unlimited Placement Test by Cambridge University Press 2010 could fit better our purposes. English Unlimited Placement Test by Cambridge is a universal English test used to test students' proficiency level.

That test is created according to the levels that the Common European Framework of Reference for Languages sets and includes all the corresponding levels from A1 to C2. This test has several parts such as speaking, listening, reading and writing. However, the only part we used was the written one. There are two main reasons for using only the written part: timing and utility. Although we were interested in giving our participants the entire exam we did not have a lot of time because, as I said before, our Corpus texts are made by students who were taking classes at high school. Therefore, we could not ask for more hours in order to add the whole test. The second reason was utility; our Corpus was going to be a written corpus. That is why we believe that oral data was not necessary to be collected. The written part we used was composed by 120 multiple choice questions, 20 at each level from A1 to C2, also known as Starter to Advanced level.

Then, we administered our participants an elicitation task in which our subjects had to write a story. The former is designed to elicit the use of the nine morphemes that we study. The name of this elicitation task was "Frog where are you?" by Mayer 1969 (see appendix 3). Although that story is based on twenty four pictures, we just used twelve of them because our students would not have enough time to compose the whole story. Therefore we chose those pictures we thought useful in order to carry out the activity. The result of those changes was that our task was based on two sheets composed by 6 pictures where students could see the story of a frog and they had to write a story using those pictures. We also have to say that the reason why we chose this book was because "Frog where are you?" has been also used in other cross-sectional studies as a tool for eliciting narrative description (Berman and Slobin 1994).

Finally, the last instrument used for these data collection was the UAM Corpus Tool (O'Donnell 2009) which is a free software program designed for the annotation of text corpora and for their analysis. This instrument was used to tag, to analyze and to study the results that we got from our Corpus. One can make several projects using this tool because as we have said before it is used in several ways. It allows the selection of a text from ones Corpus, to make the necessary annotations (based on the purposes of each study) and finally enables the researcher to analyze those annotations. I will explain how we used it in subsection 4.4 (Data coding and analyses). 


\subsection{Procedure: Data collection}

Our corpus was collected in two different schools, the first samples were collected in I.E.S Catuja (Granada) during my internship and the others were collected in I.E.S Santa Catalina de Alejandría (Jaén) after talking with the principal and the English teacher in order to have their consent.

Monday $26^{\text {th }}$ March was the date we started collecting our data. The tutor, who was also the English teacher, was really helpful because she was very pleased with the idea that their students would take part in a research project.

The first group was 20ESO; it was Monday at 9:15 and we only needed one class to collect the data although I had the intention of using at least two classes. There were fourteen students but we just could get ten samples; the teacher told us that four of the students were studying in special conditions and they were not able to complete the task. Hence, I worked with ten students; seven males and three females from 13 to 14 years of age.

It was not easy to convince them to carry out the task because they knew that it would have no impact on their grade for the English Language module. Therefore, we had to convince them that these texts were really important for our study; the teacher also helped us to make them cooperate. However, once they decided to undergo this process and while we were still explaining the task, they started to write the story. When we explained them the task we spoke in Spanish to facilitate the understanding of the procedure. Our students understood the task properly because they did not ask anything.

We decided that writing the story should come first, because our meeting was just after the weekend and they felt tired. Hence, I gave them the elicitation task and they just needed around twenty five minutes to write the story.

Some of the students were not really worried about their composition and we believe that this explains why they did not ask me vocabulary. However, some of them put a lot of effort in the completion of the task given that these students do not have a high level. We should also note that some of them tried to write the story using the glossary we provided them with.

The second tool we used was the placement test. For this we asked the students to stop answering when they thought that the level was too difficult for them. This group answered just around 45 questions and they did not find difficulties while they were doing the test. The last 7 minutes were used to fill out the learner profile. We gave them a copy and we read aloud the different sections. None of them needed more than 5 minutes to fill it out. 
Second group was 2-Bachillerato; the collection took place at 11:45 after the break and although we wanted to use two classes, these participants needed only one because they were not really interested in taking part in the study. We have to say that these students' behavior was generally disappointing because they did not want to cooperate. However, thanks to the teacher, they finally wrote the story. Before that we gave them some relevant instructions such as that they should name each test with their initials and ask in case they had doubts.

They did not need more than twenty minutes to describe it, and when the finished we gave them the placement test and after that the learner profile.

The second part of the Corpus was collected in I.E.S Santa Catalina de Alejandría (Jaén) and it took place on Thursday the $22^{\text {nd }}$ of May at 12.45 . As we said before, we had to talk with the English teacher and with the principal to get their consent I order to carry out this activity. Both, the principal and the English teacher, were excited with the idea of their students participating in the project and hence we did not have any administrative problems in carrying out the data collection process.

The third group was 10 Bachillerato, we only asked for one hour of lesson but we have to say that we did not need more because these students were able to do the whole task in fifty five minutes. We gave them first the elicitation task; then we handed out the placement tests and, finally, we provided them with the learner profile form. After giving each piece of the task we explained each part. This class was really polite, they were in silence and it was really easy to collect data. The only problem we had was that students wanted to know some vocabulary but we explained that we could not help because we needed them to use their own words to create a real corpus.

The last group was 40ESO; the data collection took place at 13:45 during the last lesson of the day and students were really interested in the project. The group was composed by twelve males and eleven females; they were all studying in the bilingual program therefore they did not have any problem in writing the story. The first thing we did in this class was to introduce the researcher and to explain the reason of our project. They seemed to be interested in the topic especially while we explained the aims of our study. After that brief explanation, we gave them some instructions such as to keep silence, not to ask vocabulary for the task and to give their consent for the use of this data in our study. They understood the guidelines and they started writing the story. They needed about twenty five minutes to carry it out, then they complete the placement test in almost twenty minutes and they finally used no more than ten minutes in filling out the learner profile form. 
We have to say that in I.E.S Santa Catalina de Alejandría (Jaén) the data collection was easier than in I.E.S Catuja (Granada) because students were really interested in collaborating with us. However the reason of that could be that I.E.S Cartuja is not a bilingual school and students do not use their L2 English as easy as the students from I.E.S Santa Catalina de Alejandría do. Hence, we really appreciate those students who made their best although they did not have a high level of English.

\subsection{Data coding and analysis.}

This subsection regards the description of two different processes: transcription and tagging. Once we collected the data we started coding and analyzing the whole corpus. As we said before, our Corpus was based on a written task using Frog where are you? by Mayer 1969, therefore, when we had our participants' descriptions we transcribed them in .txt files (see appendix) and then we used the UAM Corpus Tool (O'Donnell 2009) to tag the nine morphemes we focused on, that is, the plural, the article, the possessive, the past regular, the past irregular, the copula be, the auxiliary be, the $3^{\text {rd }}$ person singular and, finally, the progressive -ing. This set of morphemes is based on Krashen (1977)

\subsubsection{Corpus transcription}

To start with, we needed to name the 77 files we created; hence we used a code to differentiate each text. That code was composed by some of the information we got from the learner profiles, i.e., age, institution the participant belonged to, the participant's initials, the course year, the researchers' initials. I had also to use the participant 's grade that was obtained in the placement test to name the files. The structure used to name the files was:

Placement_course year_age_institution_researcher's initials_participant's initials.txt

This can be illustrated with the following examples:

B1_1BAC_16_SCA_ADD_MPM.txt

A2_2ESO_13_CAR_ADD_VPS.txt

The possible variables that can be used to name the files were the following ones: 
Table 11- Code system to name the files

\begin{tabular}{|c|c|}
\hline \multicolumn{2}{|c|}{ Code system to name files } \\
\hline Placement & $\mathrm{A} 1 / \mathrm{A} 2 / \mathrm{B} 1 / \mathrm{B} 2 / \mathrm{C} 1 / \mathrm{C} 2$ \\
\hline Course year & 2ESO/4ㅌSO/ 1ㅇAC/ 2BAC \\
\hline Age & Yy \\
\hline Institution & $\begin{array}{l}\text { CAR (I.E.S Cartuja) / SCA (I.E.S Santa Catalina de } \\
\text { Alejandría) }\end{array}$ \\
\hline $\begin{array}{l}\text { Researcher's } \\
\text { initials }\end{array}$ & ADD (Agustina Demarta Dabove) \\
\hline
\end{tabular}

In order to transcribe our students' texts in the most detailed way we established a tagset to encode learners' editions of the text. The tagset was composed by five possible situations we could find in our texts: rewriting unreadable, rewriting readable, late insertion, reallocation and unreadable. We will explain them in detail in the following table:

Table 12. Learners' corrections: this tags learners' editions of their writing.

\begin{tabular}{|c|c|c|c|}
\hline Situation & Description of the situation & Tag used & Explampl \\
\hline Rewriting unreadable & $\begin{array}{l}\text { Used in cases where the participants } \\
\text { edited their text by rewriting it and the } \\
\text { original formulation is illegible. }\end{array}$ & \$_RWU_c & I bought a $* * *$ \\
\hline Rewriting readable & $\begin{array}{l}\text { Used in cases where the participants } \\
\text { edited their text by rewriting it but the } \\
\text { original formulation is legible }\end{array}$ & \$_RWR_word & I bought a frog \\
\hline Late insertion & $\begin{array}{c}\text { Used in cases where participants } \\
\text { edited their text by inserting new } \\
\text { units. }\end{array}$ & \$_Ins_word & $\begin{array}{l}\text { I bought a frog } \\
\text { green }\end{array}$ \\
\hline Reallocation & $\begin{array}{l}\text { Used in cases where participants } \\
\text { edited their text by reallocating units. } \\
\text { Two tags are needed in this case, one } \\
\text { for the old location and the other for } \\
\text { the new location. The word that is } \\
\text { reallocated occurs after both tags. }\end{array}$ & $\begin{array}{l}\text { \$_OLoc_word } \\
\text { \$_NLoc_word, }\end{array}$ & \}$_{\text {green }}^{\text {I bought afrog }}$ \\
\hline Unreadable & $\begin{array}{l}\text { Used in cases where the participants' } \\
\text { writing was unintelligible }\end{array}$ & \$_UNR_c & ] ] [נ]נ] \\
\hline
\end{tabular}


It is important to highlight that students 'files were collected in their classes and they were not in a digital format, we had to transcribe the 77 writings and create .txt files.

The fact that writing were handmade was the reason why we need to set the previous coding because several mistakes were made by them and we wanted to reproduce their text as much as possible.

\subsubsection{Corpus tagging}

As it has been previously stated, the analysis of this corpus follows Krashen's (1977) pattern. Therefore, we focused on the use of the following morphemes:

Table 13. Morphemes to be tagged follows Krashen's (1977)

\begin{tabular}{|c|l|l|c|}
\hline \multirow{4}{*}{} & \multicolumn{3}{|c|}{ Morphemes to be tagged } \\
\hline \multirow{4}{*}{$\begin{array}{c}\text { Verb related } \\
\text { morphemes }\end{array}$} & $\begin{array}{l}\text { Past regular morpheme } \\
\text { mort irregular }\end{array}$ & -ed & past_reg \\
\cline { 2 - 4 } & Verb to be as main verb & $\begin{array}{l}\text { is/are } \\
\text { was/were }\end{array}$ & pastirreg \\
\cline { 2 - 4 } & $\begin{array}{l}\text { Verb to be as auxiliary } \\
\text { verb }\end{array}$ & $\begin{array}{l}\text { is/are } \\
\text { was/were }\end{array}$ & be_aux \\
\cline { 2 - 4 } & Progressive morpheme & -ing & ing \\
\cline { 2 - 4 } & $\begin{array}{l}3^{\text {rd }} \text { person singular } \\
\text { morpheme }\end{array}$ & -s/-es & 3sg \\
\hline \multirow{2}{*}{$\begin{array}{c}\text { Noun related } \\
\text { morphemes }\end{array}$} & Possessive morpheme & -'s/s' & pos \\
\cline { 2 - 4 } & Plural morpheme & -s/-es & plu \\
\cline { 2 - 4 } & Article morpheme & the/a(n) & art \\
\hline
\end{tabular}

Regarding the tagging scheme, we used Pica (1983). The suppliance in non-obligatory context was put forth by him. There are three categories we need to know: the Obligatory Contexts, the Suppliance in Obligatory Context and finally the Suppliance in non-Obligatory Context. The detailed description of these categories is compulsory in the explanation of my study:

- The Obligatory Context $(\mathrm{OC})$ refers to the occasions in which the morpheme is expected to be used by a native speaker. In the following example we can see that the usage of the past tense form was required: -ed morpheme, escaped

"One day, my frog escape_ of my house" ${ }^{9}$

\footnotetext{
${ }^{9}$ Sample extracted from B1_4ESO_15_SCA_ADD_PMP.txt
} 
- The Suppliance in Obligatory Context (SOC) refers to the instances of correct suppliance of the morpheme at issue.

"Then my dog pushed the trunk"

- The Suppliance in non- Obligatory Context (SNOC) includes the occasions in which the morpheme is supplied but is not necessary.

"The boy hold in the one rock" 11

These are the categories used in the tagging:

Figure 4 - The tagging scheme.

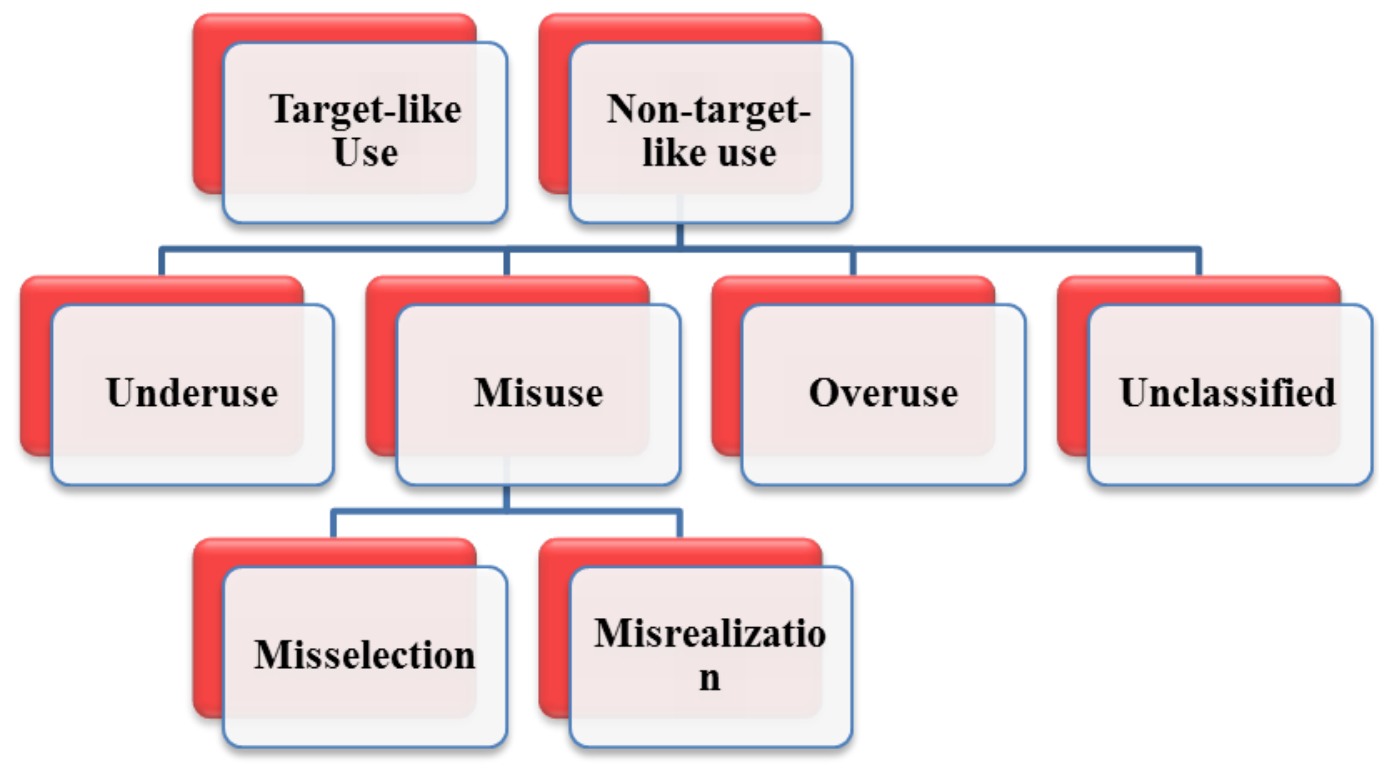

To provide a further explanation we will use the following table where we can see the tagging rationale for the "regular past" morpheme using examples.

\footnotetext{
${ }^{10}$ Sample extracted from A2_ESO_16_SCA_ADD_EQG.txt

${ }^{11}$ Sample extracted from A2_2BAC_19_CAR_ADD_MCA.txt
} 
Table 14. Tagging rationale for the "regular past" form.

\begin{tabular}{|c|c|c|c|}
\hline \multicolumn{3}{|c|}{ OC: Past reg (The frog escaped last night ) } & \multirow{2}{*}{$\begin{array}{l}\text { S: Supplied form } \\
\text { The frog escaped last } \\
\text { night }\end{array}$} \\
\hline $\begin{array}{l}\text { Targe } \\
\text { t- like } \\
\text { Use } \\
\text { (corr } \\
\text { ect form } \\
\text { supplied } \\
\text { ) }\end{array}$ & & & \\
\hline \multirow{3}{*}{$\begin{array}{l}\text { Non- } \\
\text { target- } \\
\text { like Use }\end{array}$} & $\begin{array}{l}\text { Unde } \\
\text { ruse } \\
\text { (no } \\
\text { form } \\
\text { supplied) }\end{array}$ & & $\begin{array}{l}\text { The frog escape last } \\
\text { night }\end{array}$ \\
\hline & \multirow{2}{*}{$\begin{array}{l}\text { Misu } \\
\text { se } \\
\text { (incor } \\
\text { rect for } \\
\text { supplied) }\end{array}$} & $\begin{array}{l}\text { Misselecti } \\
\text { on (form } \\
\text { exists) }\end{array}$ & $\begin{array}{l}\text { The frog escaping } \\
\text { last night }\end{array}$ \\
\hline & & $\begin{array}{l}\text { Misrealisa } \\
\text { tion } \\
\text { (form } \\
\text { does not exist) }\end{array}$ & $\begin{array}{l}\text { The frog scaped last } \\
\text { night }\end{array}$ \\
\hline \multicolumn{3}{|c|}{ OC: ing (The frog is escaped $\{=$ escaping $\}$ ) } & SNOC \\
\hline & & $\begin{array}{l}\text { Overuse } \\
\text { (correct } \\
\text { form supplied } \\
\text { but in NOC) }\end{array}$ & $\begin{array}{c}\text { The frog never } \\
\text { escaped }\end{array}$ \\
\hline & & ed Unclassifi & \\
\hline
\end{tabular}

- Target-like use: this tag is used to describe a situation where the correct form was supplied. As we can see in the example: The frog escaped last night.

- Non-target-like-use: This tag is used when the participant does not supply the correct morpheme. In this occasion we can find four different situations and we will use different tags to describe each one:

Underuse: it is used when the participant does not supply the morpheme that is required. For instance, "The frog escape last night" 
Misuse: it is used to describe four different situations where the participant does supply an incorrect form:

Misselection: it is used when the participant does supply a morpheme which exists but that morpheme is not the one that the context requires. For example, The frog escaping last night.

Misrealisation: it is used to describe the situation which takes place when the participant does supply a form that does not exist. For example, "The frog broked last night"

Overuse: this tag is used when we find that the participant supplies a correct form but in a not obligatory context (SNOC). For example, The frog is escaped.

Unclassified: this tag is used when we find a form that cannot be categorized in the previous scheme. 


\section{Results and Discussion}

This chapter is divided into two main sections: general results (5.1) and specific results (5.2) where we analyze our data taking into account the distribution of the target-like Use and Non-target-like Use tags according to the proficiency level of the participants (5.2.1), the school course they study in (5.2.2), and finally the usage of each morpheme (5.2.3).

We should remember that Target-like use tag is used to describe a situation where the participant supplied the correct form while the Non-Target-like Use tag is used to describe a situation where the participant did not supplied the correct morpheme form. This category is divided into: overuse, misrealisation, misselection, underuse and unclassified therefore we tagged the form according to the mistake the participants had made, as explained above.

Regarding the results, it is necessary to highlight that due to the nature of the task we provided the participants with, i.e., an adaptation of "Frog where are you?" by Mayer (1969), there was not a minimum number of morphemes to be supplied because students were free to write their composition. As a result of this characteristic of our study we have to take into account that our results are based on what they had written, that is to say, the number of correct occurrences they produced.

\subsection{General results.}

The general results are based on the number of occurrences we can find when we analyze the whole Corpus. These results are based on the analysis of the nine morphemes form and the level of accuracy that our participants reached.

To describe the latter we created table 15, where we can see the total number of occurrences and if the supplied forms were correct (target-like use) or incorrect (non-target-like use) while table 16 shows the same data but it is expressed in percentages. 
Table 15. General results. Target-like use vs. Non-target-like use.

\begin{tabular}{|c|c|c|c|}
\hline Morphemes & $\begin{array}{c}\text { Target-like } \\
\text { Use }\end{array}$ & $\begin{array}{c}\text { Non-target-like } \\
\text { Use }\end{array}$ & Total occurrences \\
\hline Past regular & 336 & 188 & 524 \\
\hline Past irregular & 383 & 178 & 22 \\
\hline 3P Singular & 4 & 18 & 173 \\
\hline Ing & 147 & 26 & 233 \\
\hline Be Cop & 200 & 33 & 154 \\
\hline Be Aux & 121 & 33 & 116 \\
\hline Plurals & 99 & 17 & 1544 \\
\hline Articles & 1409 & 135 & 16 \\
\hline Possessive & 13 & 3 & \\
\hline
\end{tabular}

Table 16. Number of occurrences expressed by percentages.

\begin{tabular}{|c|c|c|}
\hline Morphemes & $\begin{array}{c}\text { Target- } \\
\text { like Use }\end{array}$ & $\begin{array}{c}\text { Non-target-lie } \\
\text { Use }\end{array}$ \\
\hline Past regular & $64.12 \%$ & $35.87 \%$ \\
\hline Past irregular & $68.27 \%$ & $33.96 \%$ \\
\hline 3P Singular & $18.18 \%$ & $81.81 \%$ \\
\hline Ing & $84.97 \%$ & $15.02 \%$ \\
\hline Be Cop & $85.83 \%$ & $14.16 \%$ \\
\hline Be Aux & $78.57 \%$ & $21.48 \%$ \\
\hline Plurals & $85.34 \%$ & $14.65 \%$ \\
\hline Articles & $91.25 \%$ & $8.74 \%$ \\
\hline Possessive & $81.25 \%$ & $18.75 \%$ \\
\hline
\end{tabular}

As we can observe both the past regular and the past irregular obtain a similar rank in the list. In the first case, the past regular forms received 524 tags of which 336 were supplied correctly therefore, there was a $64.12 \%$ of correctness in the usage of this morpheme. A similar percentage is found when we analyze the past irregular form; the participants supplied it correctly 383 times out of 561 numbers of occurrences. 
However, the third person singular $-\mathrm{s}$ had the worse level of accuracy, since the participants could only supply its correct form in the $18.18 \%$ of the times. We should highlight that, due the nature of the task, the analysis of this morpheme is complicated, because participants used to write in the past and hence not to use the singular $-\mathrm{s}$ morpheme. We will explain this issue in the conclusion part.

As for the -ing form, there were 173 occurrences and the participants reached a level of accuracy of $84.97 \%$. The -ing morpheme was used 173 times of which just only 26 tags belong to the non-target-like use tag. The use of the verb to be is similar in its auxiliary and its copula form, although we can observe that the participants have a higher level of accuracy when they use the copula form; the copula form received 233 tags of which the $85.83 \%$ were tagged under target -like use, while the auxiliary form received 154 tags of which the $78.57 \%$ were tagged under target -like use.

The usage of the plural form is equivalent to 116 occurrences of which the $85.34 \%$ was correctly used, and just the remaining $14.65 \%$ of the instances display a non-target like use. Hence, we can say that there was a high level of accuracy within this morpheme. Analyzing the results obtained from the plural form, we realize that this morpheme has the highest level of accuracy; it was used 1544 times of which the 91. $25 \%$ were supplied correctly while just the $8.74 \%$ were tagged under non target-like use.

Finally, the possessive form received the following results: $81.25 \%$ of the morphemes were used in the correct way and the $18.75 \%$ were not used correctly.

Using the following figure we can visualize the general results we have obtained.

Figure 5 . General results. Percentages.

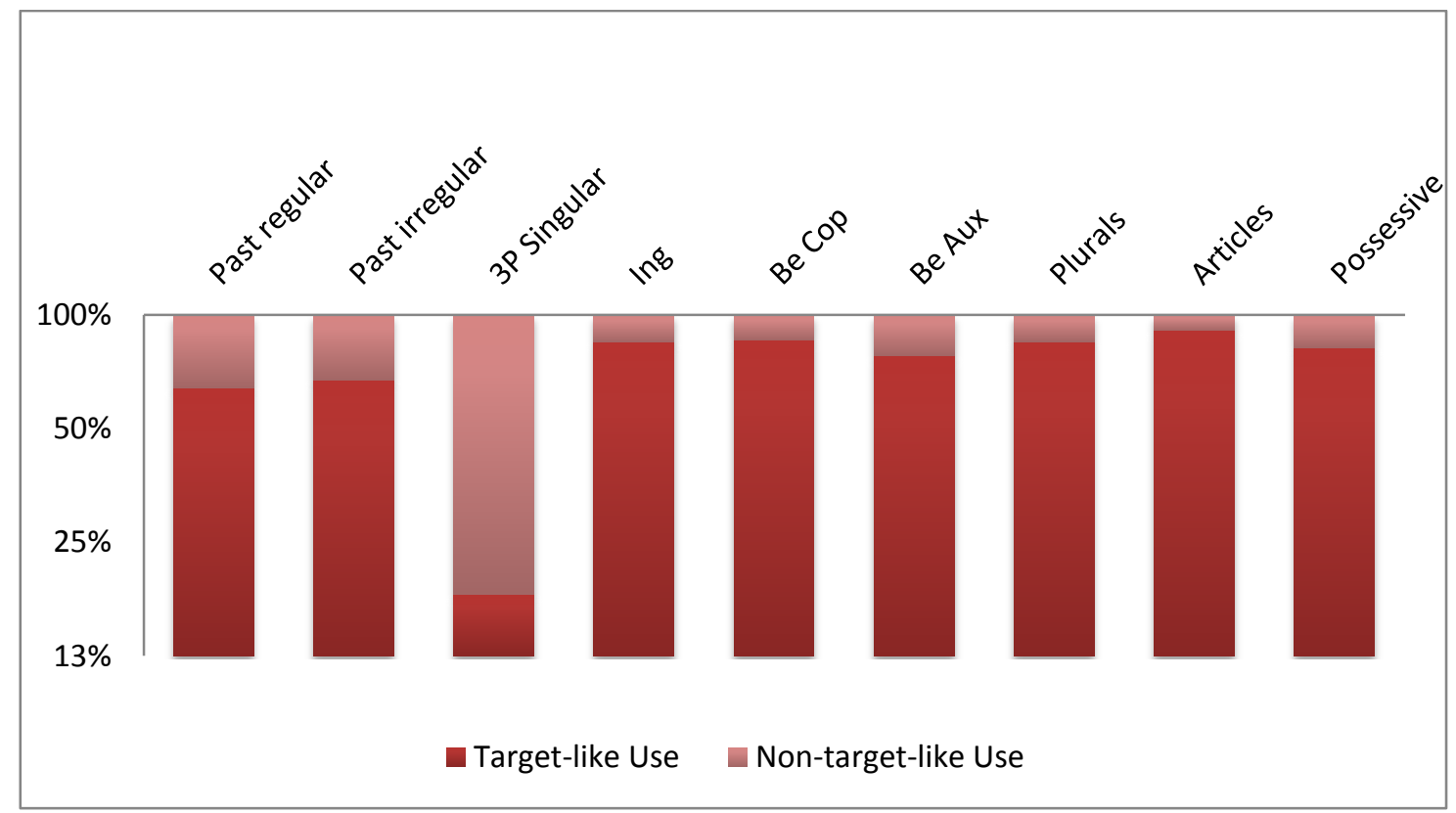


As it has been explained in section 4.4.2 "Corpus tagging", the morphemes could be placed either in the target-like use or the non-target-like use categories. Non-target-like use means that the correct form was not supplied; in that case we tag the morpheme with one of the following labels "underuse", "misselection", "misrealisation", "overuse" or "unclassified" depending on the type of error that the participant makes.

In the table number ? and in figure number? we can see the results according to the participant 'suppliance of each morpheme. To start with, we have to highlight that in the right column of the table we have the total number of non-target-like use tags and in the middle part of the table we have the different categories. As we can see the most frequent category is underuse and the least frequent one is unclassified.

Table 17. Non-target like use results

\begin{tabular}{|c|r|c|c|c|c|}
\hline Morphemes & Underuse & Misselection & Misrealisation & Overuse & Unclassified \\
\hline Past regular & $86.70 \%$ & $0.53 \%$ & $12.23 \%$ & $0 \%$ & 1 \\
\hline Past irregular & $71.91 \%$ & $5.05 \%$ & $16.85 \%$ & $4.49 \%$ & $1.68 \%$ \\
\hline 3P Singular & $72.22 \%$ & $11.11 \%$ & $0 \%$ & $16.66 \%$ & $0 \%$ \\
\hline Ing & $46.15 \%$ & $3.84 \%$ & $26.92 \%$ & $23.07 \%$ & $0 \%$ \\
\hline Be Cop & $21.21 \%$ & $45.45 \%$ & $12.12 \%$ & $21.21 \%$ & $0 \%$ \\
\hline Be Aux & $21.21 \%$ & $15.15 \%$ & $3.03 \%$ & $60.60 \%$ & $0 \%$ \\
\hline Plurals & $17.64 \%$ & $52.94 \%$ & $5.88 \%$ & $23.52 \%$ & $0 \%$ \\
\hline Articles & $41.48 \%$ & $28.14 \%$ & $2.22 \%$ & $20 \%$ & $8.14 \%$ \\
\hline Possessive & $0 \%$ & $0 \%$ & $33.33 \%$ & $66.66 \%$ & $0 \%$ \\
\hline
\end{tabular}


The next figure shows the distribution of the non-target-like use categories according to the usage of the morphemes.

Figure 6-Non-target like use results

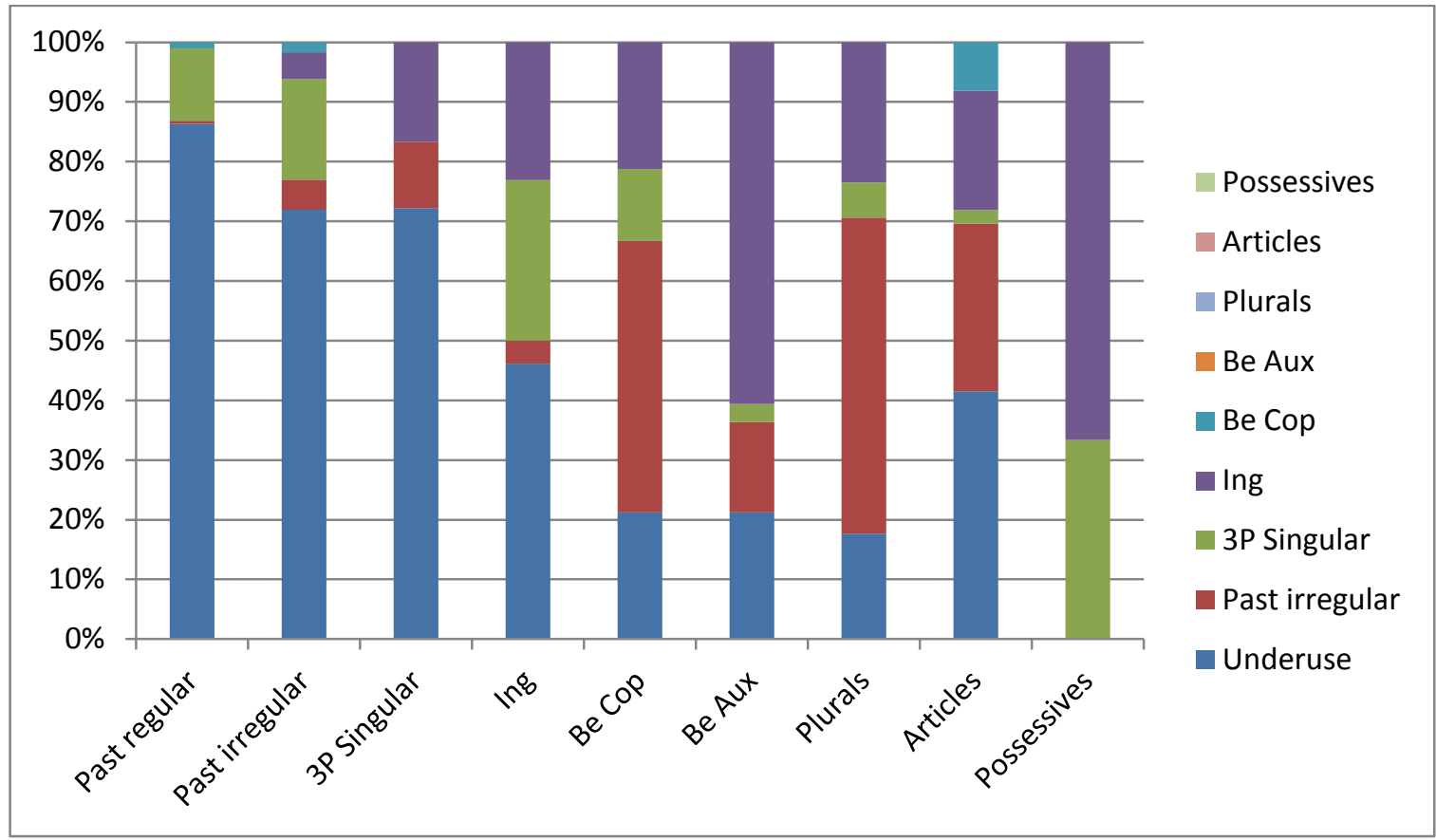

As shown, the underuse category is the most frequent one; we can see that participants do not use correctly the past regular and past irregular morphemes. That was due to the fact that some participants did use the present tense instead of the past one because they did not know the correct tense form or they did not know the correct past irregular form for the verbs.

In turn, the results tagged under the misselection, misrealisation and overuse categories are similar. If we analyze the elicitation tasks we find that there were not found many examples of unclassified forms. In the following subsection we will analyze these results taking into account the level of proficiency. This will enable us to see the aforementioned errors in depth.

\section{2 Specific results}

In this subsection we will try to analyze results taking into account the participants 'proficiency level (5.2.1); the course year they study in (5.2.2) and finally we will study the level of accuracy of each morpheme taking into account the participants' proficiency level (5.2.3). 


\subsubsection{According to proficiency levels}

To start with, we should remind that there are 6 levels of proficiency; participants could be placed from $A 1$ to $C 1$, that is to say, from beginners to advanced English speakers. In order to express these results we divided them into Non-target-like use (underuse, U; Misselection, ML; misrealisation, MR; overuse, O; unclassified, UNC) and target like use (T-L U).

A1 group: The more significant piece of information we have obtained from the following figure and table is that participants who belong to A1 do not really manage the use of both the past regular and past irregular morphemes, and the plural -s functor. However, they have used correctly the -ing form and they did not seem to have big problems with the use of the verb to be as, both, auxiliary and copula neither had they difficulties in the use of the articles. In turn, they did not use the possessive $-s$ and the third person singular morphemes probably because they were not familiar with these forms.

Table 18. Target like use and Non-target like use. Number of occurrence A1

\begin{tabular}{|c|c|c|c|c|c|c|}
\hline \multicolumn{7}{|c|}{ A1 } \\
\hline \\
\hline
\end{tabular}


Figure 7. Target like use and Non-target like use results. Number of occurrences A1. Percentages

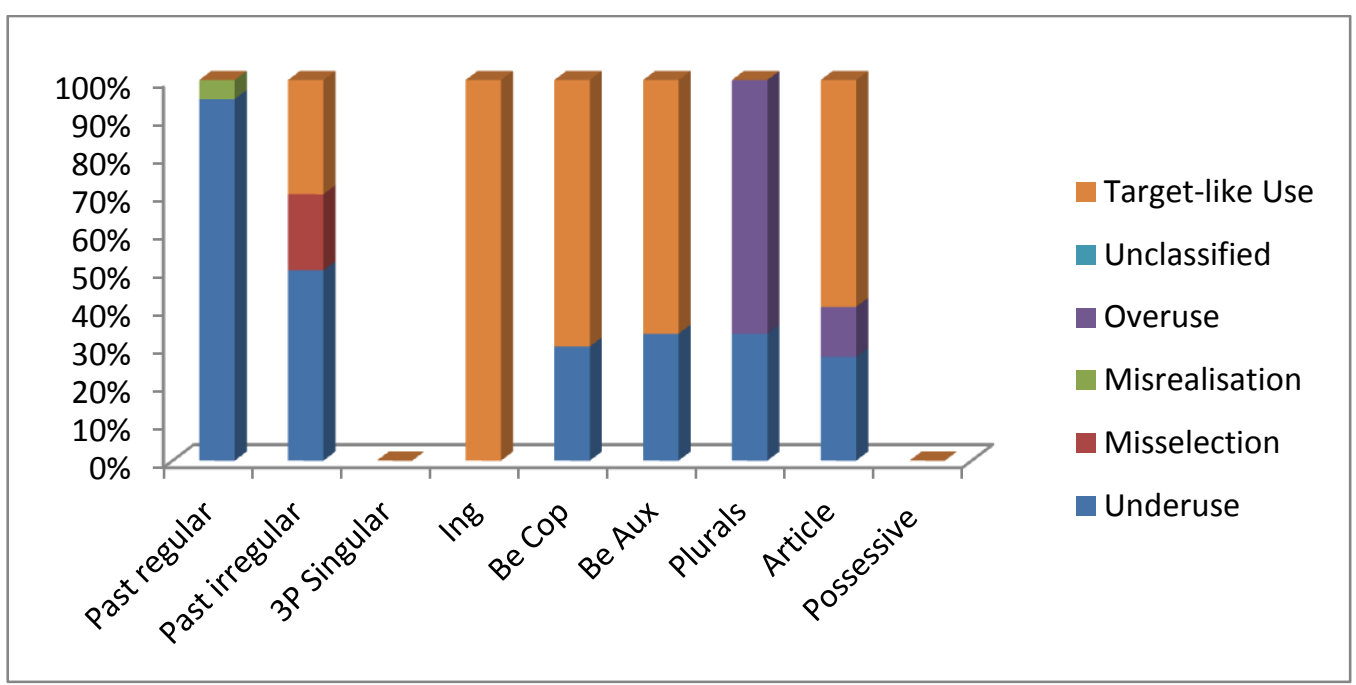

A2 group: Participants who obtained an A2 level of proficiency were able to manage the plural and the article form; they obtained the best level of accuracy in the use of both forms. However, we can still notice that the use of both past regular and irregular is not the correct one; students seem to have difficulties with these morphemes. It is important to say that, at this level, the participants tried to use the third person singular $-\mathrm{s}$, although they did not manage to reach high accuracy levels. They used it 18 times of which just 4 of them were used correctly.

The -ing form plays a similar role than in A1 level of proficiency because students seemed to handle quite easily this morpheme.

It cannot be ignored the fact that our participants did not use the possessive form at this level. This could be explained by a possible unfamiliarity or lack of knowledge of the aforementioned morpheme. Lastly, the use of the form be as copula or auxiliary is quite similar, that is, participants were able to use them in a correct way in the majority of the cases. 
Table 19. Target like use and Non-target like use. Number of occurrence A2

\begin{tabular}{|c|c|c|r|r|r|r|}
\hline \multicolumn{7}{|c|}{ A2 } \\
\cline { 1 - 5 } & NON TARGET LIKE USE & \multirow{2}{*}{ T-LU } \\
\cline { 1 - 5 } P. R & 77 & 1 & 7 & 0 & 0 & 26 \\
\hline P. I & 64 & 6 & 4 & 2 & 0 & 43 \\
\hline 3P S & 12 & 2 & 0 & 0 & 0 & 4 \\
\hline Ing & 10 & 0 & 1 & 4 & 0 & 22 \\
\hline Be C. & 4 & 12 & 0 & 6 & 0 & 22 \\
\hline Be A. & 5 & 3 & 0 & 18 & 0 & 23 \\
\hline Plu & 2 & 0 & 0 & 1 & 0 & 11 \\
\hline Art & 29 & 23 & 0 & 15 & 0 & 303 \\
\hline Poss & 0 & 0 & 0 & 0 & 0 & 0 \\
\hline
\end{tabular}

Figure 8. Target like use and Non-target like use results. Number of occurrences A2. Percentages

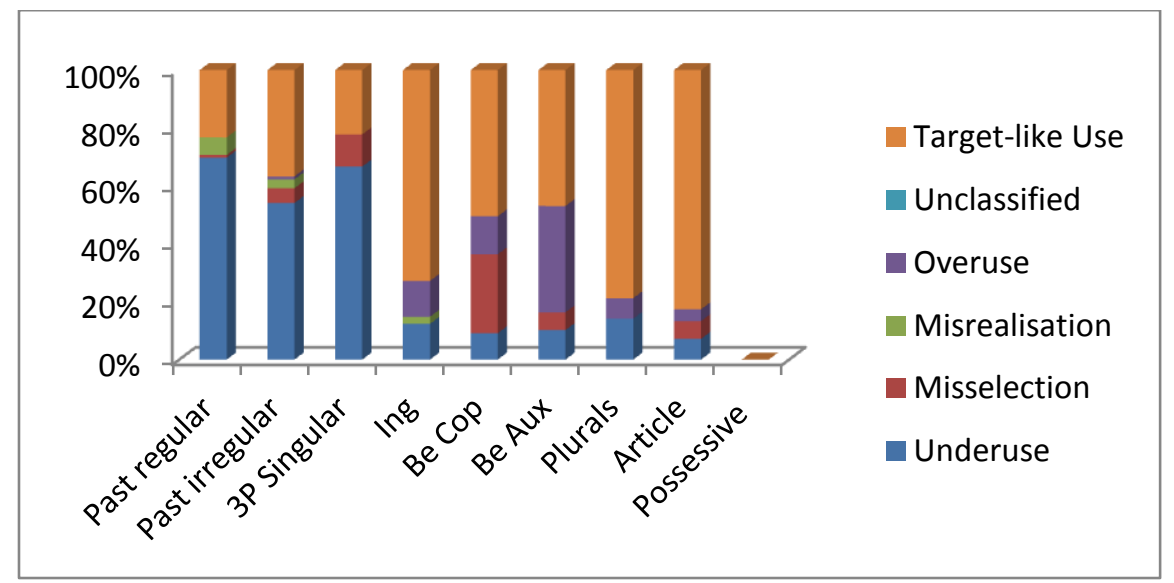

B1 group: Figure number 9 is based on the data we obtained from the first level of the intermediate stage, B1. At this level we can observe that participants manage the use of the article and the be copula form. However, the possessive $-\mathrm{s}$ and the third person singular are the morphemes which obtained the less level of accuracy. As we can observe there is a remarkable difference on the correct use of both past regular and irregular forms. At this point participants were also able to manage the ing, be copula, be auxiliary and article morphemes. Finally, we should highlight that the participants who belonged to the intermediate level had some problems when using the plural forms. 
Table 20. Target like use and Non-target like use. Number of occurrence B1

\begin{tabular}{|c|c|c|c|c|c|c|}
\hline \multicolumn{7}{|c|}{ B1 } \\
\hline & \multicolumn{5}{|c|}{ NON TARGET LIKE USE } & \multirow{2}{*}{$\begin{array}{l}\text { T- } \\
\text { LU }\end{array}$} \\
\hline & U & ML & MR & 0 & UNC & \\
\hline P.R. & 35 & 0 & 12 & 0 & 1 & 141 \\
\hline P.I. & 39 & 0 & 13 & 3 & 2 & 170 \\
\hline 3PS & 0 & 0 & 0 & 2 & 0 & 0 \\
\hline Ing & 1 & 0 & 4 & 2 & 0 & 50 \\
\hline Be C. & 0 & 2 & 1 & 1 & 0 & 88 \\
\hline Be A. & 0 & 1 & 1 & 2 & 0 & 44 \\
\hline Plu & 0 & 9 & 0 & 0 & 0 & 44 \\
\hline Art & 5 & 10 & 1 & 2 & 5 & 559 \\
\hline Poss & 0 & 0 & 0 & 1 & 0 & 11 \\
\hline
\end{tabular}

Figure 9. Target like use and Non-target like use results. Number of occurrences B1. Percentages

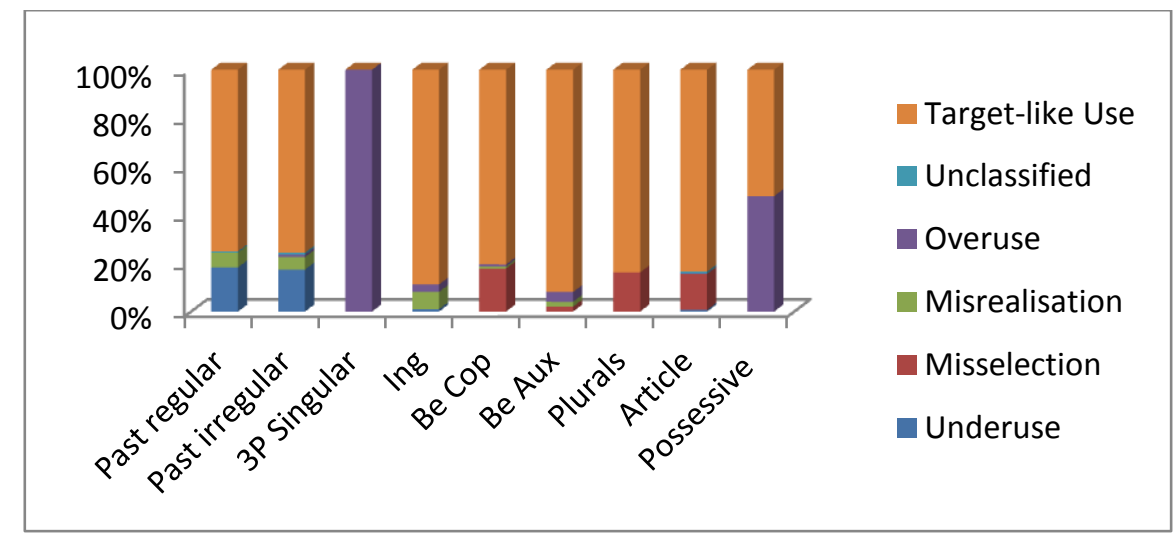

B2 group: It is obvious that errors occur less frequently as we study learner language produced by higher proficiency level participants.

As this point we can observe that most of the participants were able to manage the -ing, the "be copula", the "be auxiliary", the plurals and the articles. The correctness in the use of the past regular and the past irregular has increased from the lower level. On the other hand, the participants were not able to use correctly the possessive -s. Finally, we should say that at this level we did not find third person singular forms. 
Table 21. Target like use and Non-target like use. Number of occurrence B2

\begin{tabular}{|c|r|r|r|r|r|c|}
\hline \multicolumn{7}{|c|}{ B2 } \\
\hline & \multicolumn{7}{|c|}{ NON TARGET LIKE USE } & \\
\hline P. R. & 23 & 0 & 3 & 0 & 0 & 111 \\
\hline P. I. & 15 & 0 & 9 & 2 & 1 & 122 \\
\hline 3PS & 0 & 0 & 0 & 0 & 0 & 0 \\
\hline Ing & 0 & 0 & 1 & 0 & 0 & 44 \\
\hline Be C. & 0 & 0 & 1 & 0 & 0 & 60 \\
\hline Be A. & 1 & 0 & 0 & 0 & 0 & 34 \\
\hline Plu & 0 & 0 & 0 & 0 & 0 & 32 \\
\hline Art & 1 & 4 & 1 & 0 & 6 & 338 \\
\hline PosS & 0 & 0 & 1 & 1 & 0 & 1 \\
\hline & & & & & & T-LU \\
\hline
\end{tabular}

Figure 10. Target like use and Non-target like use results. Number of occurrences B2. Percentages

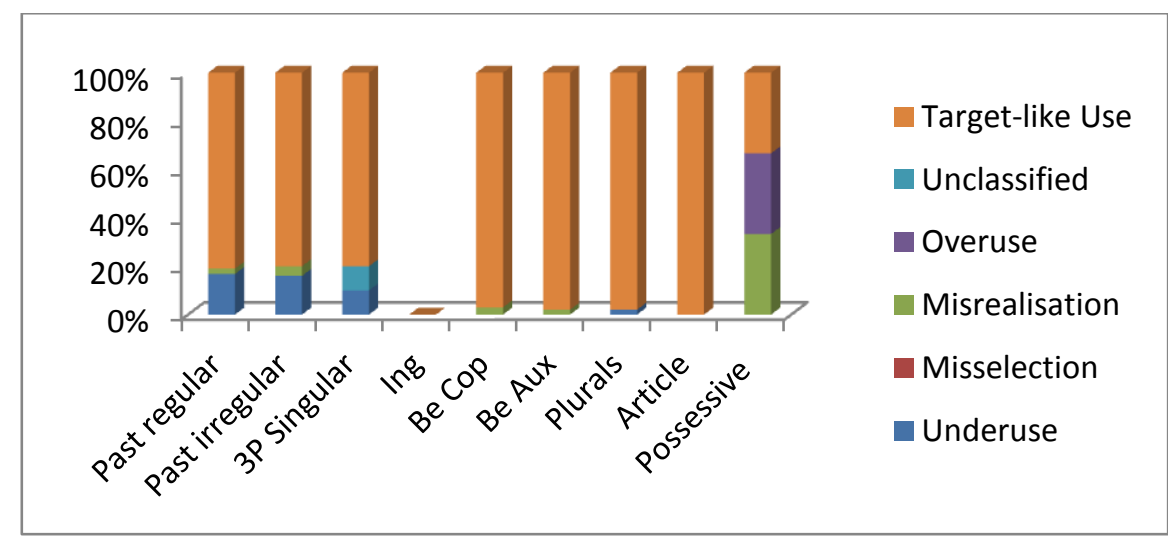

C1 group: Lastly, in our highest level of proficiency (C1) we can see that our participants managed to use correctly the past irregular morpheme. Indeed, they got only 7 morphemes tagged under the nontarget like use (out of 65 total occurrences). They also obtained a good result in the use of the past irregular morpheme, but it was not as good as the past regular one. The correctness in the use of the progressive -ing, the "be copula", the "be auxiliary", the plurals and the articles were similar. Finally, we should focus our attention on the third person singular and on the possessive form because they were not able to produce those morphemes and even when they did it, they failed. 
Table 22. Target like use and Non-target like use. Number of occurrence C1

\begin{tabular}{|c|c|c|c|c|c|c|}
\hline & \multicolumn{7}{|c|}{ C1 } & \multirow{2}{*}{ T-LU } \\
\hline & U & ML & MR & O & UNC & \\
\hline P.R & 7 & 0 & 0 & 0 & 0 & 58 \\
\hline P.I & 5 & 1 & 4 & 1 & 0 & 45 \\
\hline 3PS & 1 & 0 & 0 & 1 & 0 & 0 \\
\hline Ing & 1 & 1 & 1 & 0 & 0 & 28 \\
\hline Be C. & 12 & 1 & 7 & 6 & 1 & 147 \\
\hline Be A. & 7 & 5 & 1 & 20 & 0 & 121 \\
\hline Plu & 3 & 9 & 1 & 4 & 0 & 99 \\
\hline Art & 56 & 38 & 3 & 27 & 11 & 1409 \\
\hline Poss & 0 & 0 & 1 & 2 & 0 & 13 \\
\hline
\end{tabular}

Figure 11. Target like use and Non-target like use results. Number of occurrences C1. Percentages

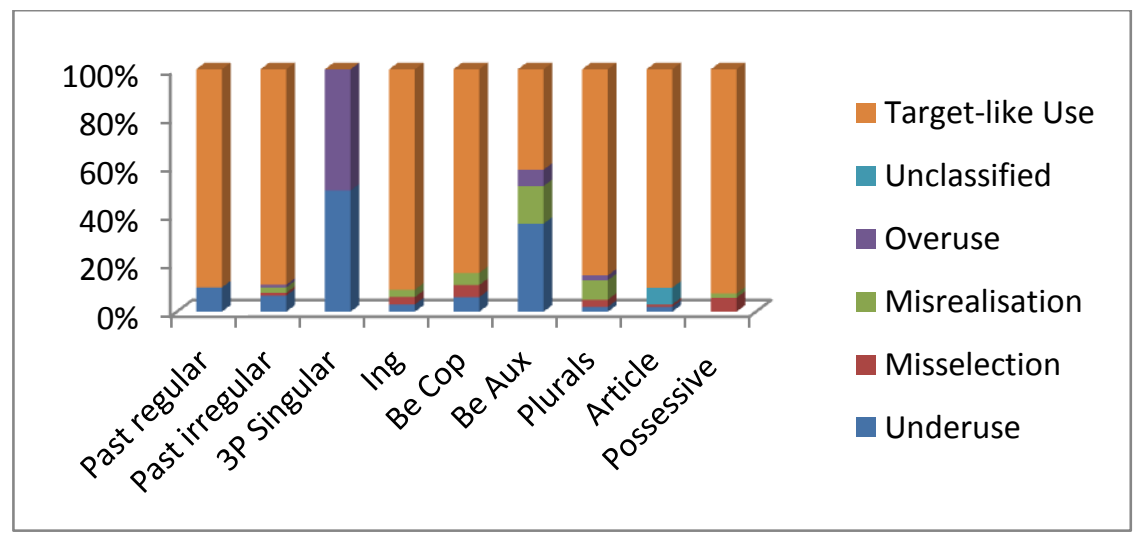

\subsubsection{According to the course year.}

This corpus is based on participants who belonged to four course years: 2ESO, 4ESO, 1BAC, 2 BAC. As we explained in section 4, both the 4ESO and the 2BAC participated in a bilingual program, while the rest of the courses did not. Therefore, we found interesting the idea of having a brief look to the results taking from that perspective. 
20 ESO: As we can observe the participants who belong to this course year had several difficulties in the use of the past irregular morpheme. We should take into account that they used the past regular morpheme 59 times, 50 of which were tagged under the non- target like use category. Additionally, they used the past irregular morpheme 40 times, 25 of which were non-target like use instances. That difference could be because the students felt more comfortable with the use of the past regular form. However, we are not claiming that they were aware of their linguistic attitude. That is, they did not realize that they were not using it in the correct way.

The third person singular and the possessive forms were not found among these samples. In turn, the -Ing, the "be auxiliary" and the articles had a similar level of accuracy while the use of the "be copula" and the plurals had a lower level of correctness.

Table 23. Target like use and Non-target like use. Number of occurrence 2ESO

\begin{tabular}{|c|c|c|c|c|c|c|}
\hline \multicolumn{7}{|c|}{ 2ESO } \\
\cline { 1 - 4 } & \multicolumn{7}{|c|}{ NON TARGET LIKE USE } & \multirow{2}{*}{ T-LU } \\
\hline P.R & 56 & 0 & 0 & 0 & 0 & 3 \\
\hline P.I & 20 & 3 & 1 & 1 & 0 & 15 \\
\hline 3P S & 0 & 0 & 0 & 0 & 0 & 0 \\
\hline Ing & 3 & 0 & 0 & 2 & 0 & 13 \\
\hline Be C. & 4 & 4 & 0 & 3 & 0 & 14 \\
\hline Be A. & 1 & 1 & 0 & 1 & 0 & 14 \\
\hline Plu & 3 & 0 & 0 & 2 & 0 & 4 \\
\hline Art & 30 & 10 & 0 & 14 & 0 & 162 \\
\hline Poss & 0 & 0 & 0 & 0 & 0 & 0 \\
\hline
\end{tabular}


Figure 12. Target like use and Non-target like use results. Number of occurrences 2ESO. Percentages

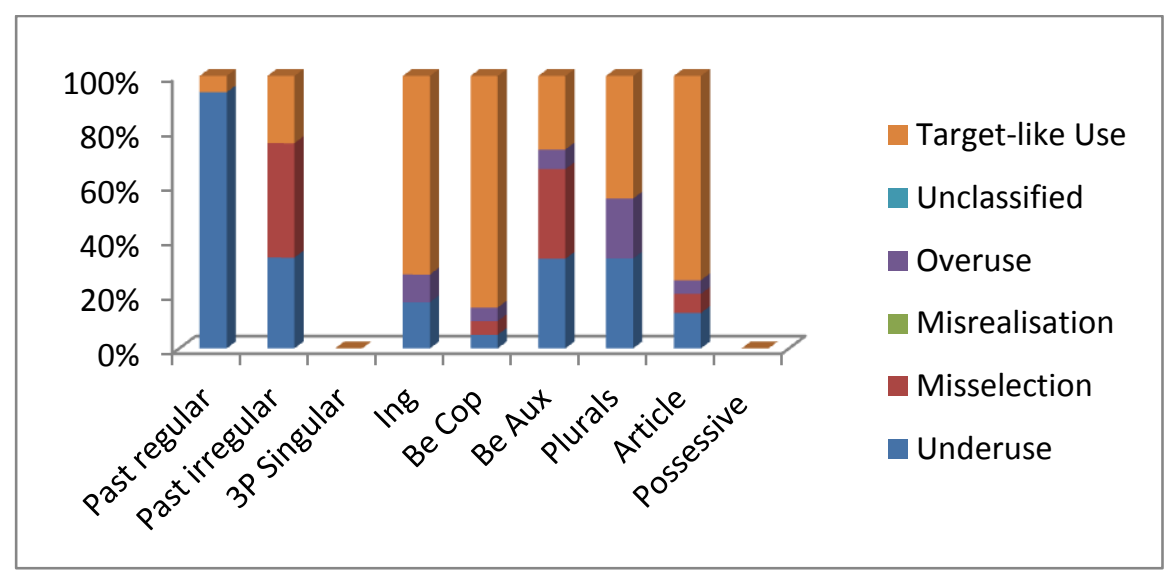

40 ESO (bilingual group): We found out that participants who belonged to this course year had no notable difficulties in the use of most of the morphemes. If we see figure number 13 the only one which we should examine further is the use of the third person singular. However, if we pay attention to the table we have above we can see that the number of occurrences of that morpheme was equal to one. Therefore, that piece of information could not be as relevant as it initially seemed. Participants at this level were able to correctly supply both past tenses' morphemes and, in general, there was not a remarkable level of incorrectness and the rest of the morphemes were all practically placed in the targetlike use category.

Table 24. Target like use and Non-target like use. Number of occurrence 4ESO

\begin{tabular}{|c|c|c|c|c|c|c|}
\hline \multicolumn{7}{|c|}{ 4ESO } \\
\hline & \multicolumn{5}{|c|}{ NON TARGET LIKE USE } & \multirow{2}{*}{ T-LU } \\
\hline & $\mathbf{U}$ & ML & MR & 0 & UNC & \\
\hline P.R & 24 & 1 & 9 & 0 & 1 & 118 \\
\hline P.I & 44 & 0 & 9 & 3 & 0 & 142 \\
\hline 3PS & 0 & 0 & 0 & 1 & 0 & 0 \\
\hline Ing & 1 & 0 & 0 & 0 & 0 & 39 \\
\hline Be C. & 0 & 1 & 1 & 1 & 0 & 72 \\
\hline Be A. & 0 & 1 & 0 & 3 & 0 & 37 \\
\hline Plu & 0 & 0 & 0 & 0 & 0 & 39 \\
\hline Art & 3 & 4 & 0 & 0 & 0 & 384 \\
\hline Poss & 0 & 0 & 0 & 1 & 0 & 6 \\
\hline
\end{tabular}


Figure 13. Target like use and Non-target like use results. Number of occurrences 4ESO. Percentages

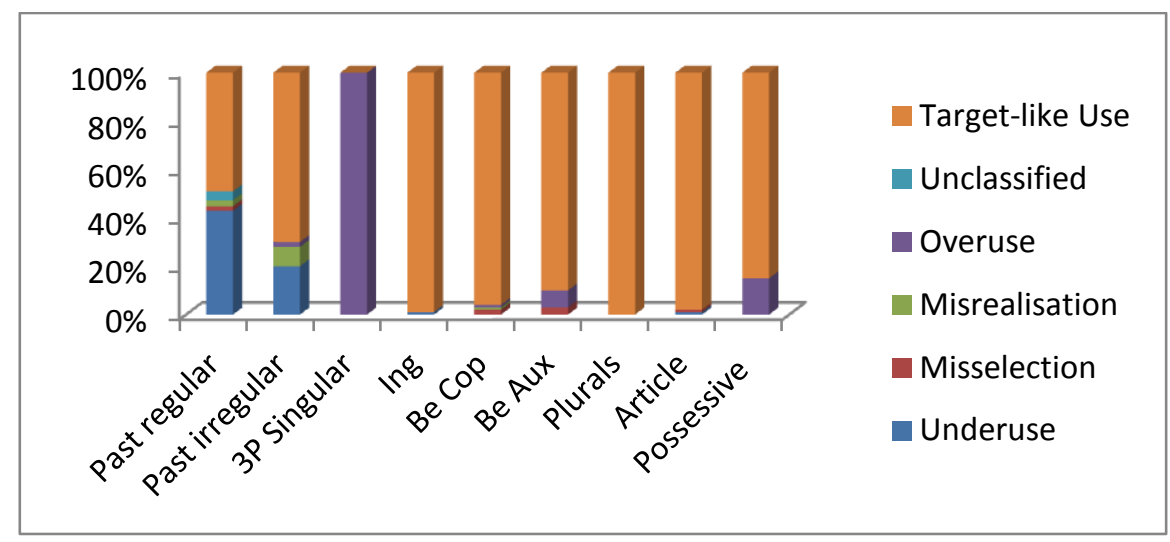

10 Bachillerato: This group has the higher level of accuracy regarding the use of the nine morphemes. It is due to the fact that the lowest level of proficiency that students from this class obtained was B1 (9 students). Furthermore, this was the only group where we can find C1 samples (7 students), whereas the rest of the class obtained a B2 level (13 students).

Taking into account the number of occurrences of each morpheme we can affirm that the participants who belong to this group managed to use in a correct way the nine morphemes. The only significant variance that we found regards the use of the third person singular. However, this piece of information can turn ambiguous if we consider that the number of this morpheme's total occurrences is 3 . That is, although the percentage seems high, the information is influenced by the small number of the relevant OC.

Table 25. Target like use and Non-target like use. Number of occurrence 1BAC

\begin{tabular}{|c|r|r|r|r|r|r|}
\hline & \multicolumn{7}{|c|}{ NON TARGET LIKE USE } & \multirow{2}{*}{ T-LU } \\
\hline & U & ML & MR & O & UNC & \\
\hline P.R & 49 & 0 & 7 & 0 & 0 & 172 \\
\hline P.I & 30 & 1 & 16 & 3 & 2 & 171 \\
\hline 3PS & 1 & 0 & 0 & 2 & 0 & 0 \\
\hline Ing & 2 & 1 & 3 & 2 & 0 & 70 \\
\hline Be C. & 0 & 2 & 3 & 0 & 0 & 93 \\
\hline Be A. & 0 & 1 & 1 & 0 & 0 & 53 \\
\hline Plu & 0 & 9 & 1 & 1 & 0 & 44 \\
\hline Art & 5 & 7 & 2 & 2 & 10 & 560 \\
\hline Poss & 0 & 0 & 1 & 1 & 0 & 5 \\
\hline
\end{tabular}


Figure 14. Target like use and Non-target like use results. Number of occurrences 1BAC. Percentages

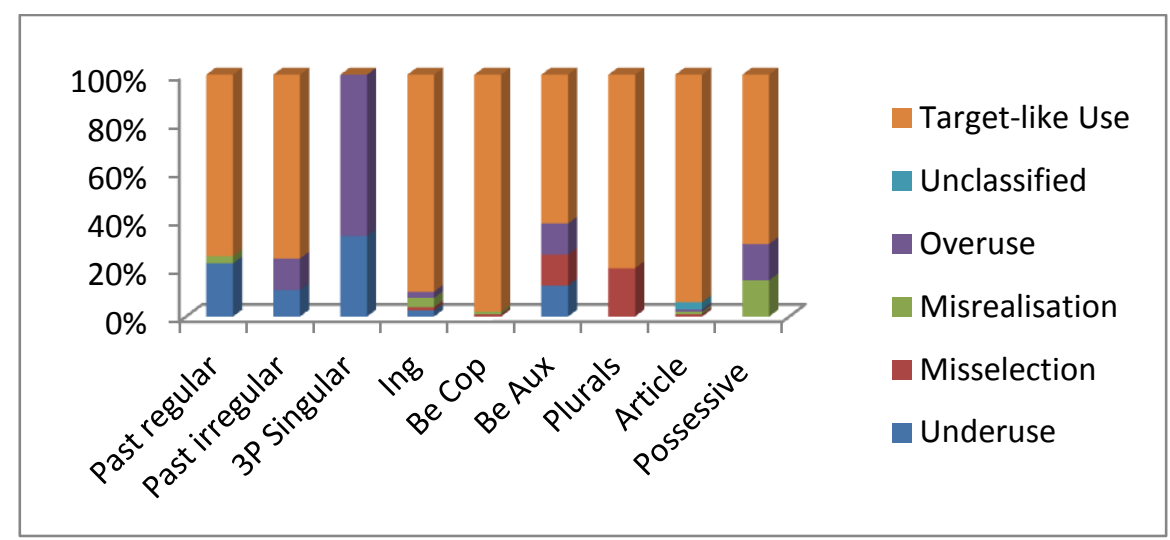

20 Bachillerato (bilingual group): This is the last group we are going to review. As we can see the use of articles, plurals and possessive form have obtained the best results, that is, students were able to manage these morphemes when they used them. However, we also found that the third person singular is not used correctly in the majority of the cases. The correctness in the use of the -ing, the past regular and the past irregular is similar. In turn, both forms of the "be" morpheme, i.e. the auxiliary and the copula, did not get a high level of accuracy.

Table 26. Target like use and Non-target like use. Number of occurrence 2BAC

\begin{tabular}{|c|c|c|c|c|c|c|}
\hline & \multicolumn{7}{|c|}{ 2BAC } & \multirow{2}{*}{ T-LU } \\
\hline & U & ML & MR & O & UNC & \\
\hline P.R & 34 & 0 & 4 & 0 & 0 & 43 \\
\hline P.I & 34 & 5 & 4 & 1 & 1 & 55 \\
\hline 3PS & 12 & 2 & 0 & 0 & 0 & 4 \\
\hline Ing & 6 & 0 & 4 & 2 & 0 & 25 \\
\hline Be C. & 3 & 8 & 0 & 3 & 0 & 21 \\
\hline Be A & 6 & 2 & 0 & 16 & 0 & 17 \\
\hline Plu & 0 & 0 & 0 & 1 & 0 & 12 \\
\hline Art & 18 & 17 & 1 & 11 & 1 & 303 \\
\hline Poss & 0 & 0 & 0 & 0 & 0 & 2 \\
\hline
\end{tabular}


Figure 15 Target like use and Non-target like use results. Number of occurrences 2BAC. Percentages

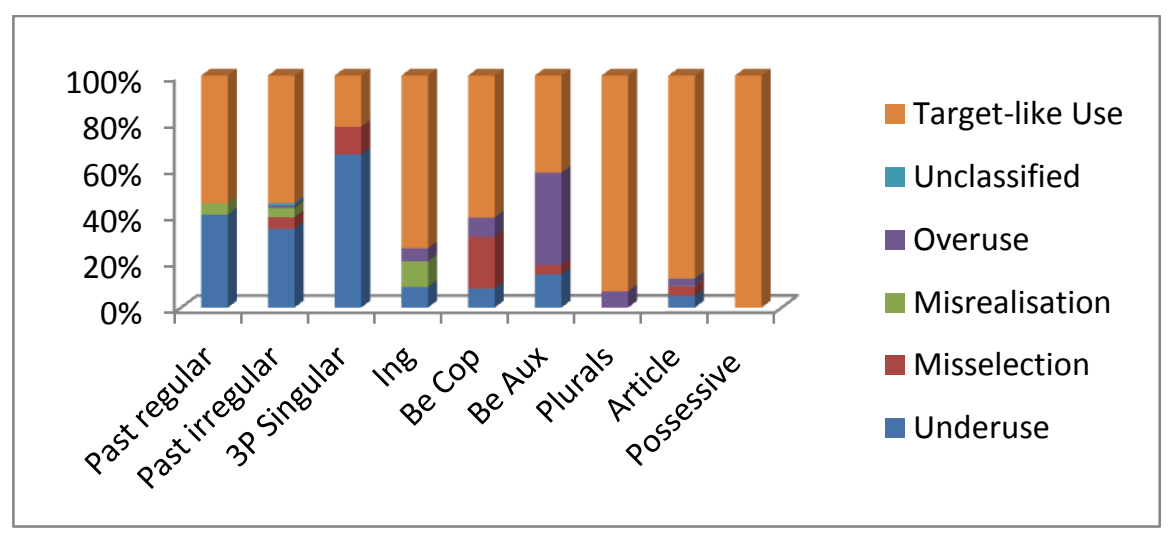

\subsubsection{According to the usage of the morphemes}

This subsection focuses on the use of the nine morphemes within the five different levels of proficiency obtained by our participants. As we will further explain in the following part of this study, (6.Discussion) one of the main aims of this project is to find out if there exists a morpheme acquisition order and if the syllabus that our participants followed in their English classes take into account that order. Therefore, what we are going to study in this part of the study is the results we have obtained from comparing the use of each single morpheme throughout the 5 levels of proficiency.

Past regular: As it can be observed in figure number 27 the past regular morpheme had a low level of accuracy in the first two stages. In that respect, we can observe that there is a remarkable change in terms of accuracy level between the beginner and the intermediate levels of proficiency. Students who belong to the beginners' level are not able to manage the use of this morpheme in a correct way. Furthermore, it is important to highlight that the most common error they made was classified as underuse, since the students did not mark the past tense on the verb form. That is, they did not distinguish the present and the past forms. It could be probably due to the fact that they are not familiar to the past tense morphemes, perhaps because they have focused on other morphemes that seem to be easily acquired. Finally, we can realize that the process of the acquisition of this morpheme had an abrupt change and it is normal that students have difficulties in the use of this morpheme at this very initial stage because as we can see here once they reach a higher level they are able to use it in the correct way. 
Table 27. Target like use and Non-target like use. Number of occurrence Past regular

\begin{tabular}{|c|r|r|r|r|r|c|}
\hline \multicolumn{7}{|c|}{ Past regular } \\
\cline { 1 - 4 } & \multicolumn{7}{|c|}{ NON TARGET LIKE USE } & \multirow{2}{*}{ T-LU } \\
\hline A1 & 21 & 0 & 1 & 0 & 0 & 0 \\
\hline A2 & 77 & 1 & 7 & 0 & 0 & 26 \\
\hline B1 & 35 & 0 & 12 & 0 & 1 & 141 \\
\hline B2 & 23 & 0 & 3 & 0 & 0 & 111 \\
\hline C1 & 7 & 0 & 0 & 0 & 0 & 58 \\
\hline
\end{tabular}

Figure 16. Target like use and Non-target like use results. Number of occurrences Past Regular.

Percentages

\begin{tabular}{|r|l|}
\hline $100 \%$ \\
$80 \%$ \\
$60 \%$ \\
$40 \%$ \\
$20 \%$ \\
$0 \%$
\end{tabular}

Past irregular. To start with, we can state that the use of the past irregular morpheme displays a case similar to the past regular morpheme that we have already studied. That is to say, there is a remarkable difference in the results obtained at the beginner's level on the one hand, and the intermediate and the advanced levels on the other. We can also see that the majority of the instances were tagged as nontarget-like use. Recall that in this category also belong the underuse which implies that the students did not mark the past form, they used the present tense instead. It is significant that, once students reach the intermediate level, they are able to use this morpheme correctly. Indeed, both the B1 and the C1 levels obtained similar accuracy rates regarding the past tense morphemes. Finally, we would like to state that there are several cases of "misrealisation", especially within the C1 level, where students handle several irregular past forms and they probably got confused with the different verbs they know.

Table 28. Target like use and Non-target like use. Number of occurrence Past irregular 


\begin{tabular}{|c|r|r|r|r|r|c|}
\hline \multicolumn{7}{|c|}{ Past irregular } \\
\cline { 1 - 4 } & \multicolumn{5}{|c|}{ NON TARGET LIKE USE } & \multirow{2}{*}{ T-LU } \\
\hline A1 & U & ML & MR & O & UNC & \\
\hline A2 & 64 & 6 & 4 & 2 & 0 & 43 \\
\hline B1 & 39 & 0 & 13 & 3 & 2 & 170 \\
\hline B2 & 15 & 0 & 9 & 2 & 1 & 122 \\
\hline C1 & 5 & 1 & 4 & 1 & 0 & 45 \\
\hline
\end{tabular}

Figure 17. Target like use and Non-target like use results. Number of occurrences Past Irregular.

Percentages

\begin{tabular}{|l|l|l|}
$100 \%$ \\
$80 \%$ \\
$60 \%$ \\
$40 \%$ \\
$20 \%$ \\
$0 \%$
\end{tabular}

$3^{\text {rd }}$ person singular. The third person singular $-s$ is one of those morphemes that appeared scarcely in our participants' language and hence we consider that we have not enough information to study this morpheme deeply. The reason for the small number of $\mathrm{OC}$ for the $3^{\text {rd }}$ person singular is that our elicitation task, as we explained before, consists of the narration of a story for which most students at our proficiency levels preferred the use of the past tense morphemes. However, we got some samples where the participant used it and we have to say that the results were not good. As we can see the participants from levels A1 and B2 did not use at all this morpheme. In turn, we found 18 instances of the aforementioned morpheme at the level A2 since only 4 forms were correctly supplied. Finally, at level B1 there were just two cases where the participants were not able to use the form correctly.

The fact that students did not use this morpheme could be due to the nature of our task or to the fact they did not feel comfortable with this structure. 
Table 29. Target like use and Non-target like use. Number of occurrence 3P Singular

\begin{tabular}{|c|r|r|r|r|r|c|}
\hline \multicolumn{7}{|c|}{ 3P Singular } \\
\cline { 1 - 4 } & \multicolumn{7}{|c|}{ NON TARGET LIKE USE } & \multirow{2}{*}{ T-LU } \\
\hline A1 & 0 & 0 & 0 & 0 & 0 & 0 \\
\hline A2 & 12 & 2 & 0 & 0 & 0 & 4 \\
\hline B1 & 0 & 0 & 0 & 2 & 0 & 0 \\
\hline B2 & 0 & 0 & 0 & 0 & 0 & 0 \\
\hline C1 & 1 & 0 & 0 & 1 & 0 & 0 \\
\hline
\end{tabular}

Figure 18. Target like use and Non-target like use results. Number of occurrences 3P Singular.

Percentages

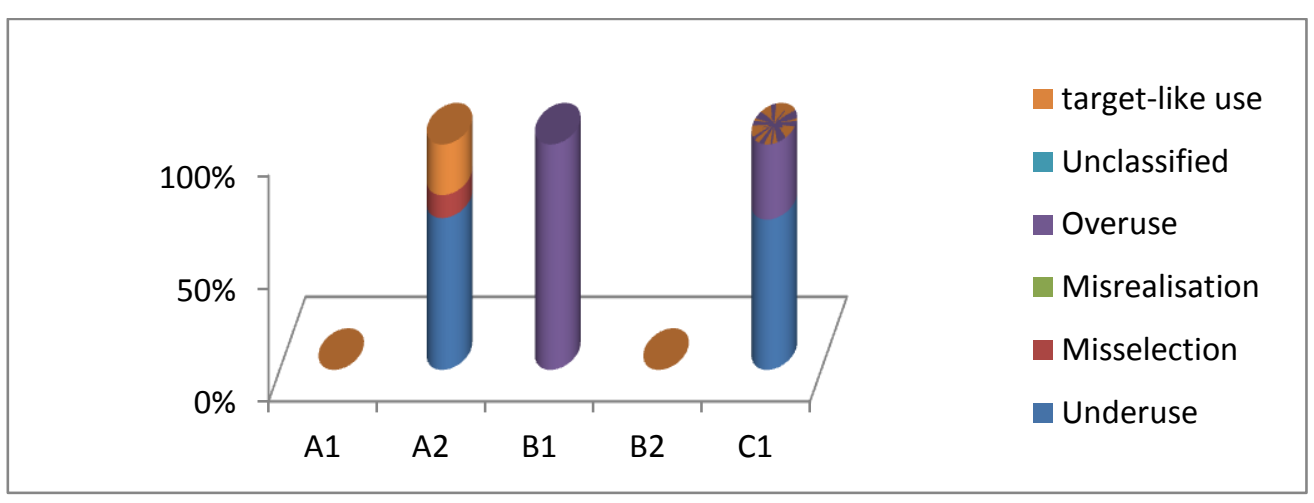

Progressive -ing: The -ing form is, as we can see in figure number 30 a well acquired morpheme because most of the students supplied it in the correct form. The only significant piece of information is that students at the $\mathrm{A} 2$ level had some difficulties in its correct suppliance. At this level, there were 37 occurrences, 10 of which were tagged as underuse; 1 was tagged as misrealisation; and, finally, 4 of the 37 belonged to the sub-category we called overuse.

It is also important to say that the B1 and B2 proficiency level participants, i.e., the ones reaching the intermediate level, were the ones who used this morpheme the most and also the ones who obtained a high level of accuracy. 
Table 30. Target like use and Non-target like use. Number of occurrence -Ing

\begin{tabular}{|c|r|r|r|r|r|r|}
\hline \multicolumn{7}{|c|}{ Ing } \\
\hline & \multicolumn{7}{|c|}{ NON TARGET LIKE USE } \\
\hline A1 & 0 & 0 & 0 & 0 & 0 & 3 \\
\hline A2 & 10 & 0 & 1 & 4 & 0 & 22 \\
\hline B1 & 1 & 0 & 4 & 2 & 0 & 50 \\
\hline B2 & 0 & 0 & 1 & 0 & 0 & 44 \\
\hline C1 & 1 & 1 & 1 & 0 & 0 & 28 \\
\hline
\end{tabular}

Figure 19. Target like use and Non-target like use results. Number of occurrences -Ing. Percentages

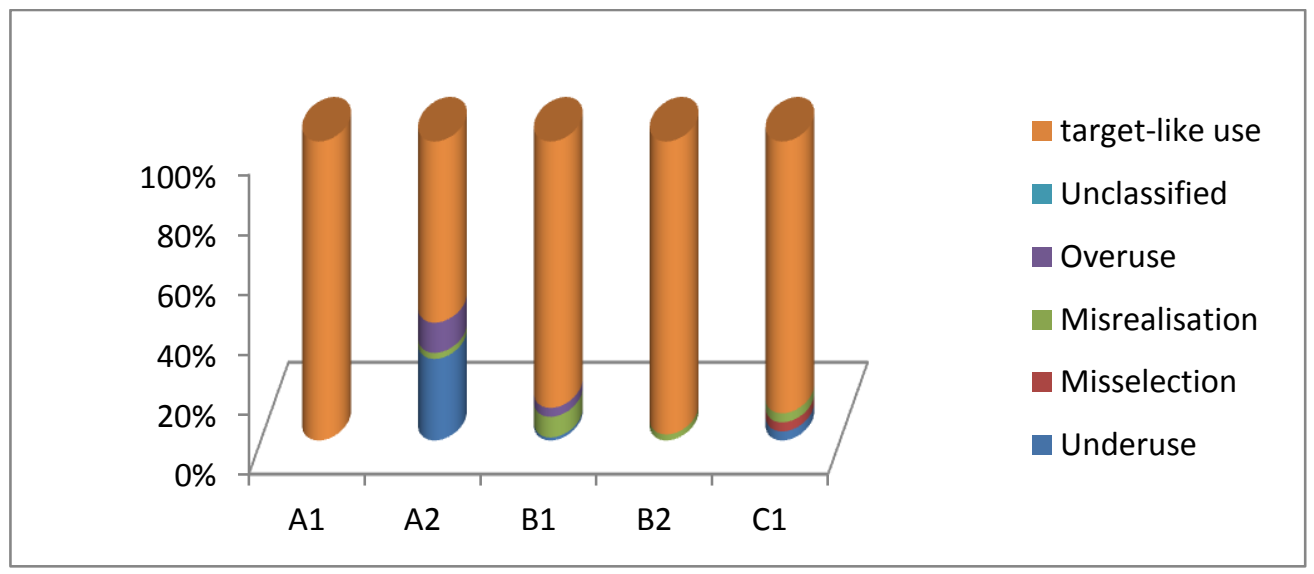

Copula "be": To start with, it is important to state that participants who belonged to the B2 proficiency level were the ones who obtained the best accuracy level in the use of this morpheme.

If we analyze our results we can also say that there is a remarkable change between the beginner's level and the intermediate one; at the first two stages, the A1 and the A2 level students were not able to manage this morpheme in the way that students at the intermediate level did. Therefore, we can state that once students achieve certain proficiency level they are able to use the "be copula" correctly. It is also important to underline that at the A2 level there were several cases of misselection, which could be due to the fact that students tried to use different plural forms with which they were not familiar yet. 
Table 31. Target like use and Non-target like use. Number of occurrence Be Cop

\begin{tabular}{|r|r|r|r|r|r|r|}
\hline \multicolumn{7}{|c|}{ Be Cop } \\
\cline { 1 - 4 } & \multicolumn{7}{|c|}{ NON TARGET LIKE USE } & \multirow{2}{*}{ T-LU } \\
\hline & U & ML & MR & O & UNC & \\
\hline A2 & 3 & 0 & 0 & 0 & 0 & 7 \\
\hline B1 & 0 & 2 & 1 & 1 & 0 & 88 \\
\hline B2 & 0 & 0 & 1 & 0 & 0 & 60 \\
\hline C1 & 12 & 1 & 7 & 6 & 1 & 147 \\
\hline
\end{tabular}

Figure 20. Target like use and Non-target like use results. Number of occurrences Be Copula.

Percentages

$\left.\begin{array}{|r|ll|}\hline 100 \% \\ 80 \% \\ 60 \% \\ 40 \% \\ 20 \%\end{array}\right]$

Auxiliary "be": As we can see in figure number 21 participants from the B1 and the B2 proficiency level had not notable issues with the use of the "be auxiliary" form. However, at the beginner's level, we find participants that were not able to use it correctly. Indeed, at the A2 level participant tended to overuse it.

It is important to say that at the $\mathrm{C} 1$ level we found several cases of overuse too. Nonetheless, there were 154 occurrences, 121 of which were correct uses of the aforementioned morpheme. Finally, the participants that had reached the B2 proficiency level obtained the best results. Out of a total of 35 occurrences only one case was tagged as non-target like use: underuse. 
Table 32 Target like use and Non-target like use. Number of occurrence Be Aux

\begin{tabular}{|c|c|c|c|c|c|c|}
\hline \multicolumn{7}{|c|}{ Be Aux } \\
\hline & UON TARGET LIKE USE & \\
\hline A1 & 1 & 0 & 0 & 0 & 0 & 2 \\
\hline A2 & 5 & 3 & 0 & 18 & 0 & 23 \\
\hline B1 & 0 & 1 & 1 & 2 & 0 & 44 \\
\hline B2 & 1 & 0 & 0 & 0 & 0 & 34 \\
\hline C1 & 7 & 5 & 1 & 20 & 0 & 121 \\
\hline
\end{tabular}

Figure 21. Target like use and Non-target like use results. Number of occurrences Be Aux.

Percentages

$\left.\begin{array}{|r|l|l|}\hline 100 \% \\ 80 \% \\ 60 \% \\ 40 \% \\ 20 \%\end{array}\right]$

Plural morphemes: According to the number of total occurrences of this morpheme in our corpus, we can state that participants who belonged to the B2 proficiency level displayed the highest level of accuracy regarding the use of this morpheme. However, we should highlight that the participants at levels B1 and C1 also seemed to feel comfortable with the accurate use of the plural. Indeed, at the C1 level we found 107 occurrences but only 17 of them were incorrectly supplied.

We should also say that the only stage in which participants had difficulties with the correct suppliance of the plural forms was the first, i.e., the level A1. There were just 3 occurrences none of which was used correctly.

Finally, we conclude that students who have reached high proficiency levels used the plural forms more frequently and correctly than the ones who are at the beginner's proficiency level. 
Table 33 Target like use and Non-target like use. Number of occurrence Plurals

\begin{tabular}{|c|c|c|c|r|r|c|}
\hline \multicolumn{7}{|c|}{ Plurals } \\
\hline & \multicolumn{7}{|c|}{ NON TARGET LIKE USE } & U \\
\hline A1 & 1 & 0 & 0 & 2 & 0 & T-LU \\
\hline A2 & 2 & 0 & 0 & 1 & 0 & 11 \\
\hline B1 & 0 & 9 & 0 & 0 & 0 & 44 \\
\hline B2 & 0 & 0 & 0 & 0 & 0 & 32 \\
\hline C1 & 3 & 9 & 1 & 4 & 0 & 99 \\
\hline
\end{tabular}

Figure 22. Target like use and Non-target like use results. Number of occurrences Plurals.

Percentages

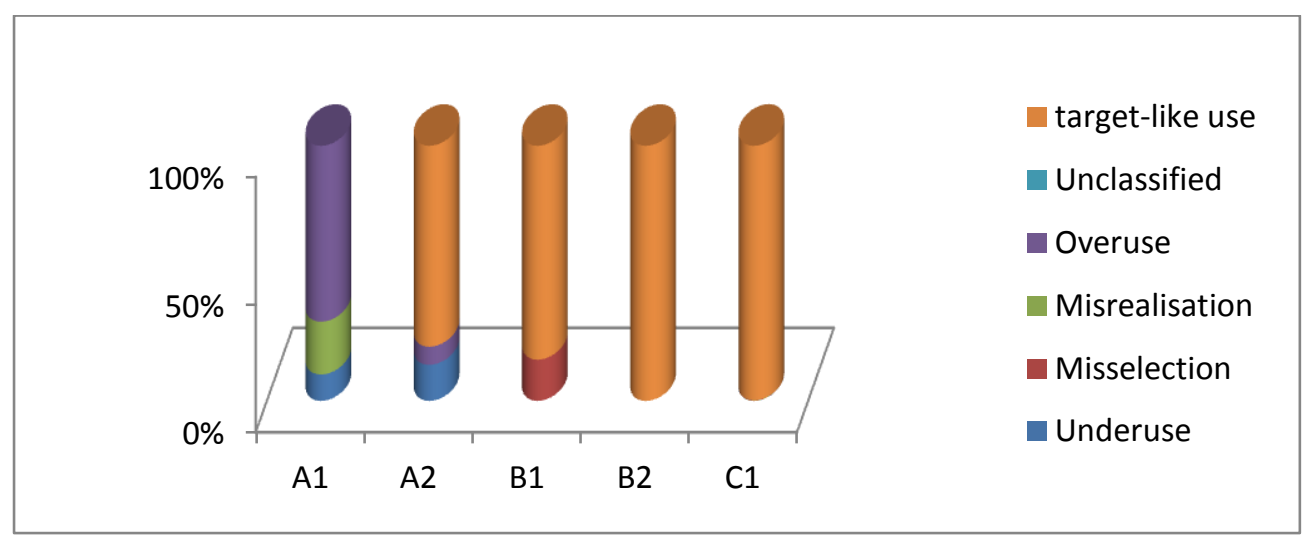

Articles: To start with, we have to say that the article form was the morpheme with the largest number of occurrences, namely, 1544. According to the number of occurrences we can state that B1 level obtained the best level of accuracy, whereas the A1 got the worse. It is important to highlight that there are several cases of overuse and underuse at the A1 level, that is, students did not use the article form when it was necessary, or they used it when it was unnecessary. However, we can see that in the next stage, i.e., A2, the level of accuracy is better and that the latter increases considerably at the higher proficiency levels 
Table 34 Target like use and Non-target like use. Number of occurrence Articles

\begin{tabular}{|c|c|c|c|c|c|c|}
\hline \multicolumn{7}{|c|}{ Articles } \\
\hline & \multicolumn{7}{|c|}{ NON TARGET LIKE USE } & \\
\hline A1 & 19 & 0 & 0 & 9 & 0 & 41 \\
\hline A2 & 29 & 23 & 0 & 15 & 0 & 303 \\
\hline B1 & 5 & 10 & 1 & 2 & 5 & 559 \\
\hline B2 & 1 & 4 & 1 & 0 & 6 & 383 \\
\hline C1 & 56 & 38 & 3 & 27 & 11 & 1409 \\
\hline
\end{tabular}

Figure 23. Target like use and Non-target like use results. Number of occurrences Articles.

\section{Percentages}

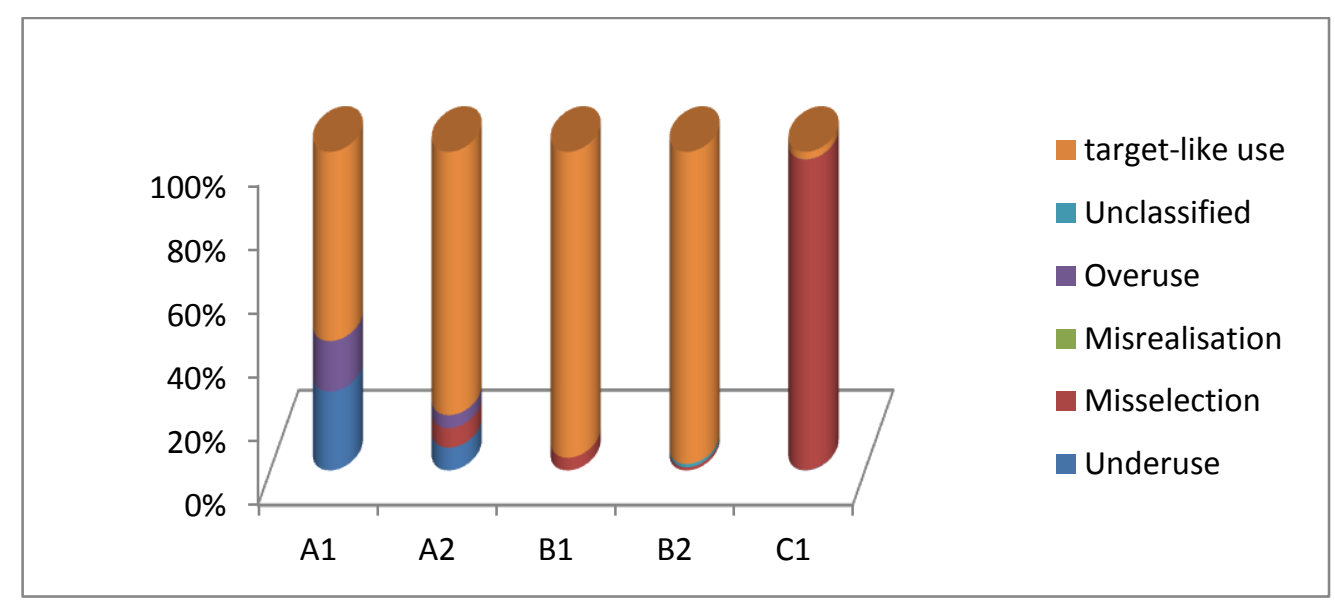

Possessive -s: The last morpheme we are going to study is the possessive -s. We should say that this morpheme was the one with the lowest number of occurrences. This could also be explained by the nature of our data elicitation task; that is to say, students were completely free to narrate a story in which the $\mathrm{OC}$ for the possessive $-\mathrm{s}$ (e.g. Ben's frog) are very few and possession can always be expressed by means of the prepositional phrase (the frog of Ben) or the possessive pronoun (his frog). So, we ended up with very few items of possessive $-\mathrm{s}$ in our learner corpus.

As we can notice in figure number?, at the initial stages students did not use this morpheme at all. In turn, at level C1 we found 16 occurrences, 13 of which were correct. 
Finally, at the intermediate level, we found that students felt more comfortable with the use of this structure; we found 12 occurrences, but only 1 was not correctly supplied.

Table 35 Target like use and Non-target like use. Number of occurrence Possessive

\begin{tabular}{|c|c|c|c|c|c|c|}
\hline \multicolumn{7}{|c|}{ Possessive } \\
\hline & \multicolumn{5}{|c|}{ NON TARGET LIKE USE } & \multirow{2}{*}{$\begin{array}{r}T- \\
\text { LU }\end{array}$} \\
\hline & U & MS & MR & $\mathbf{0}$ & $\begin{array}{l}\text { UN } \\
\text { C }\end{array}$ & \\
\hline A1 & 0 & 0 & 0 & 0 & 0 & 0 \\
\hline A2 & 0 & 0 & 0 & 0 & 0 & 0 \\
\hline B1 & 0 & 0 & 0 & 1 & 0 & 11 \\
\hline B2 & 0 & 0 & 1 & 1 & 0 & 1 \\
\hline C1 & 0 & 0 & 1 & 2 & 0 & 13 \\
\hline
\end{tabular}

Figure 24. Target like use and Non-target like use results. Number of occurrences. Possessives.

\section{Percentages}

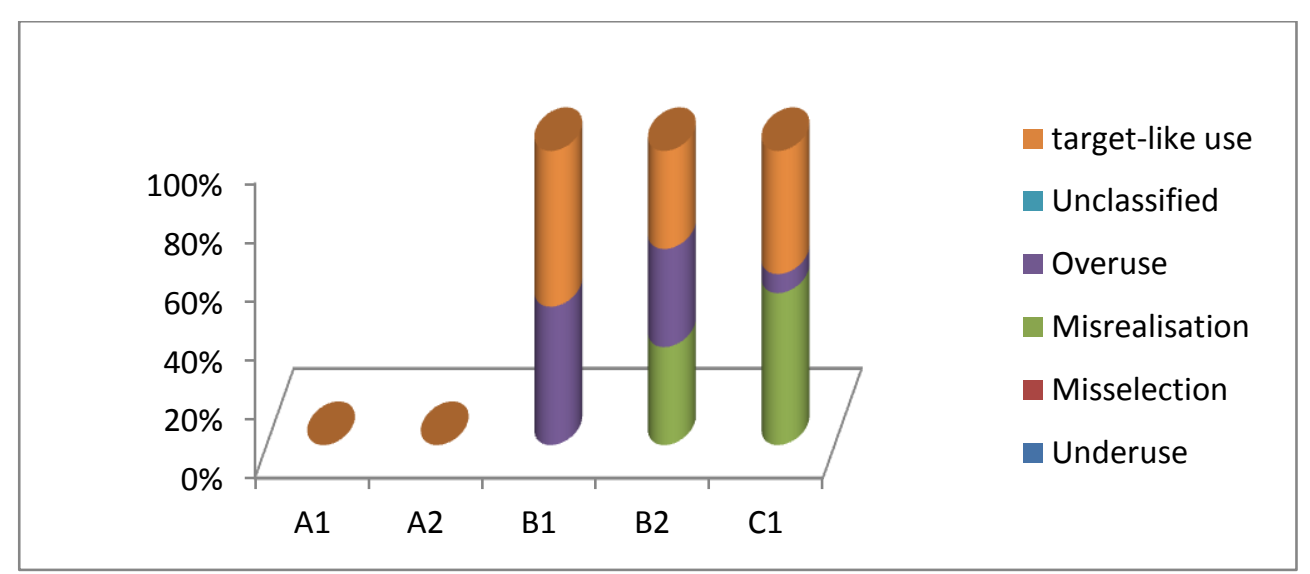

Once we have analyzed the results and discussed them as particular entities, it is possible to state the following morpheme order acquisition starting with the most well-used morpheme to the least. 


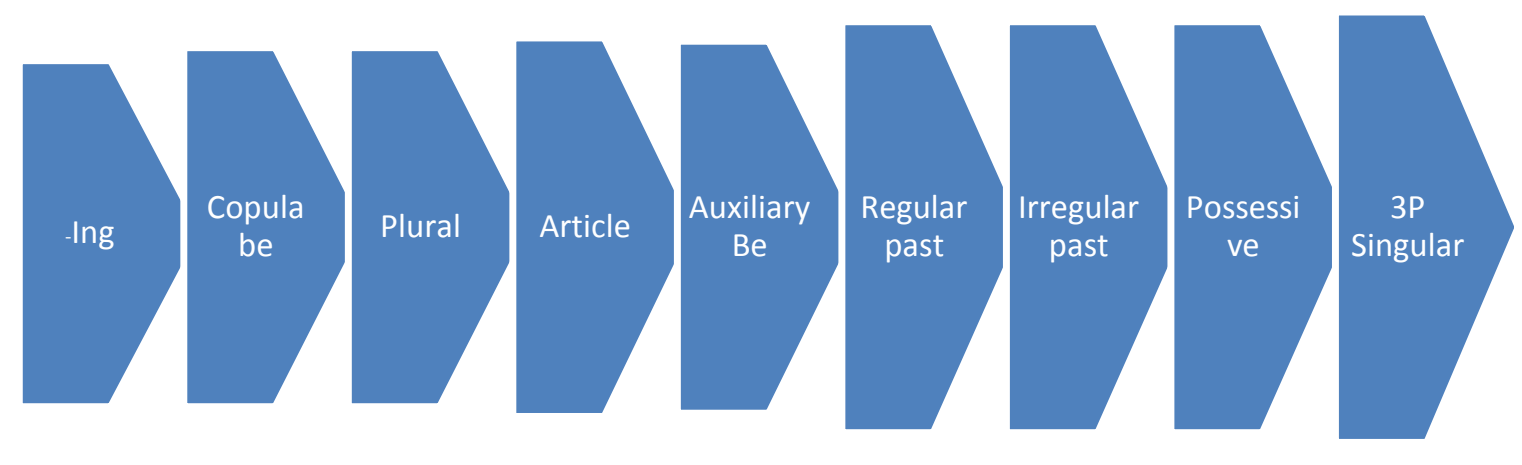

Although this sequence does not correspond exactly with the results getting by MOS we can state this sequence is quite similar to some we have discussed in the literature review. ${ }^{12}$ In other words, our study supports a similar acquisition order than the one proposed by Bailey, Madden and Krashen (1974); Rosansky (1976); Hakuta (1976); Larsen-Freeman (1975) and Dulay Burt (1974b ) among others.

However we cannot forget that the scoring of these authors, SOC scoring, is not the same that it has been carried out in this study. As we said we have used the UAM Corpus tool which provides results in percentages. Therefore, our results are calculated according to the use frequency.

Regarding the results obtained and explained we can state that the first research question that this study proposed has been examined; we have found a similar morpheme acquisition than other MOS studies have done. That is to say, this study supports the theory of morpheme order acquisition.

Once we have state there exists a given sequence in the acquisition of morphemes, we can now try to solve the second research question. It was: "do we usually take that acquisition order into account when we teach English?" in order to solve that we are going to compare the results with our students' syllabus. We are going to use the books that these students have been working with during the last school year. We are going to focus on the grammar part and we are going to discuss if each book has taken into account the well known acquisition order that some authors have proposed. It is important to say that this given sequence is not totally stated because it changes from one students to others but as we can see in our students ' results some morphemes are easily acquired than others.

\footnotetext{
${ }^{12}$ Table 2. Order of Acquisition of English Morphemes in Major L1 and L2 studies. ${ }^{12}$
} 
In the next page we can see a table extracted from the four different books that those school courses have used. We are going to start with 2ESO:

Ing

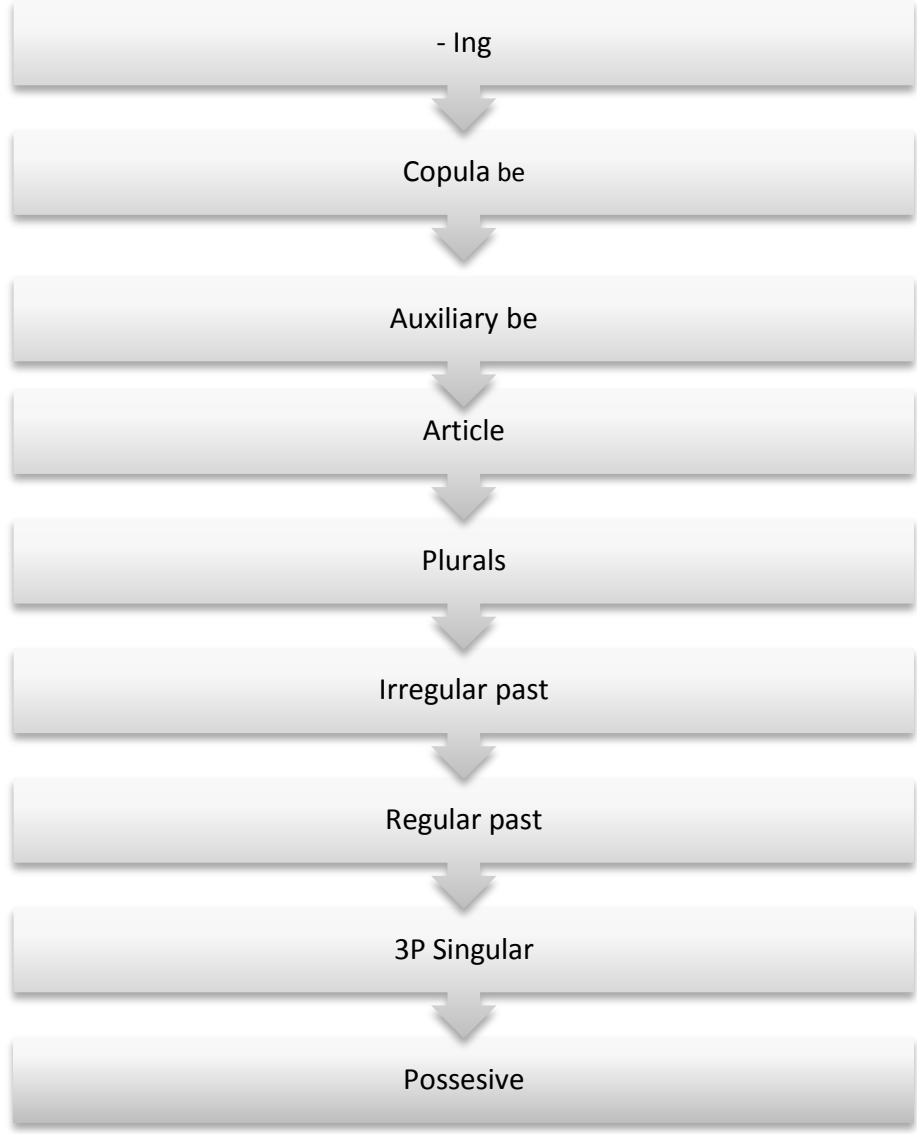

Figure 25 Sequence of morpheme acquisition 2ESO

First of all, the book that these students use is Open Roads by Norman Whitney and Tim Falla. As we can see throught the syllabus, the 3P Singular morpheme is studied in the first topic although those students do not handle it in a porper way. -Ing form is also studied in the first topic because topic number one deals with the present tenses in English. Copula be an auxiliary be are also studied in the first topic because the topic of this book are divided according to tenses. (present simple and continuous, past simple and continuous, present perfect and so on). Plurals, articles and possessive are not explained in a inductive way. In other words there are not specific topic which deal with those morpheme forms. 


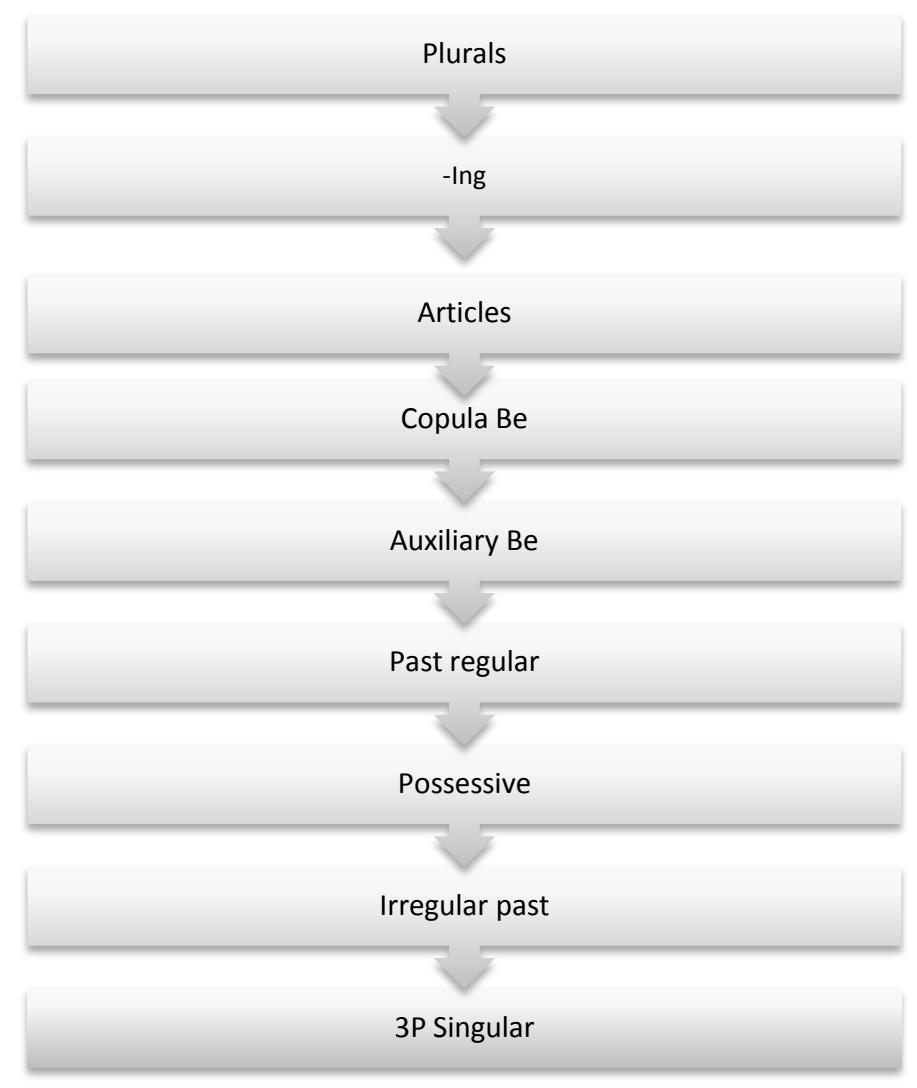

Figure 26 Sequence of morpheme acquisition 4ESO

The book that these students use is Kickstart by Kathy Gude \& Michael Duckworth. As we can see throught the syllabus, the 3P Singular morpheme is studied in the first topic although those students do not handle it in a porper way. Copula be an auxiliary be are also studied in the first topic because the topic of this book are divided according to tenses. (present simple and continuous, past simple and continuous, present perfect and so on). The article is studied in the second, fourth and eightth topis. However plurals and possessive are not explained in a inductive way. In other words there are not specific topic which deal with those morpheme forms. Both past regular and irregular are studied in the same topic (topic three). the -Ing form is studied as a isolated entity in topic number four and it is also studied in the first topic because it deals with the present tenses in English. 


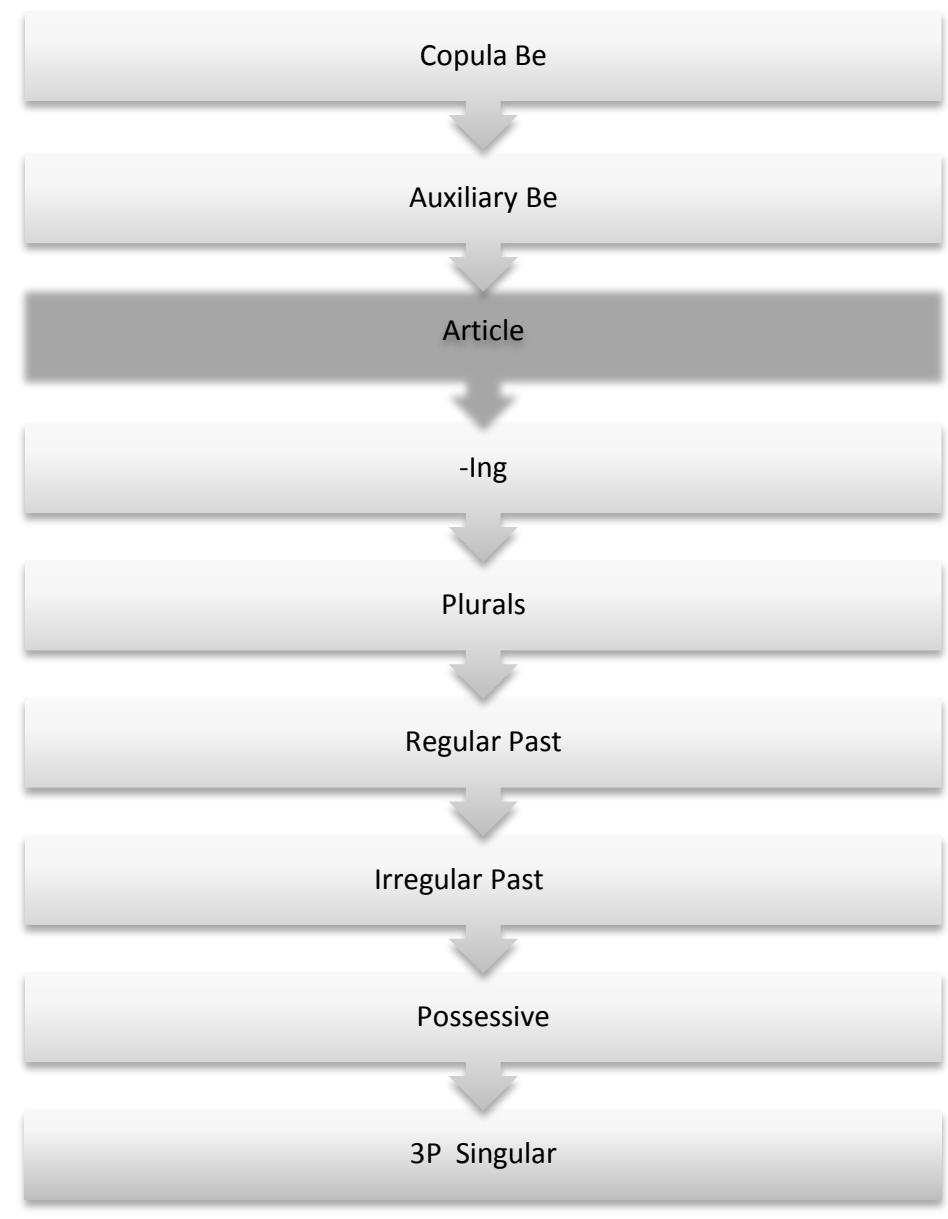

Figure 27 Sequence of morpheme acquisition 1BAC

To star with, the book that these students use is English in Mind by Hebert Puchta and Jeff Stranks. As we can see throught the syllabus, the 3P Singular morpheme is studied in the first topic although those students do not handle it in a porper way. -Ing form is also studied in the first topic because topic number one deals with the present tenses in English. Copula be an auxiliary be are also studied in the first topic because the topic of this book are divided according to tenses. (present simple and continuous, past simple and continuous, present perfect and so on). Plurals, articles and possessive are not explained in a inductive way. In other words there are not specific topic which deal with those morpheme forms. Both regular and irregular form are studied in topic two. 


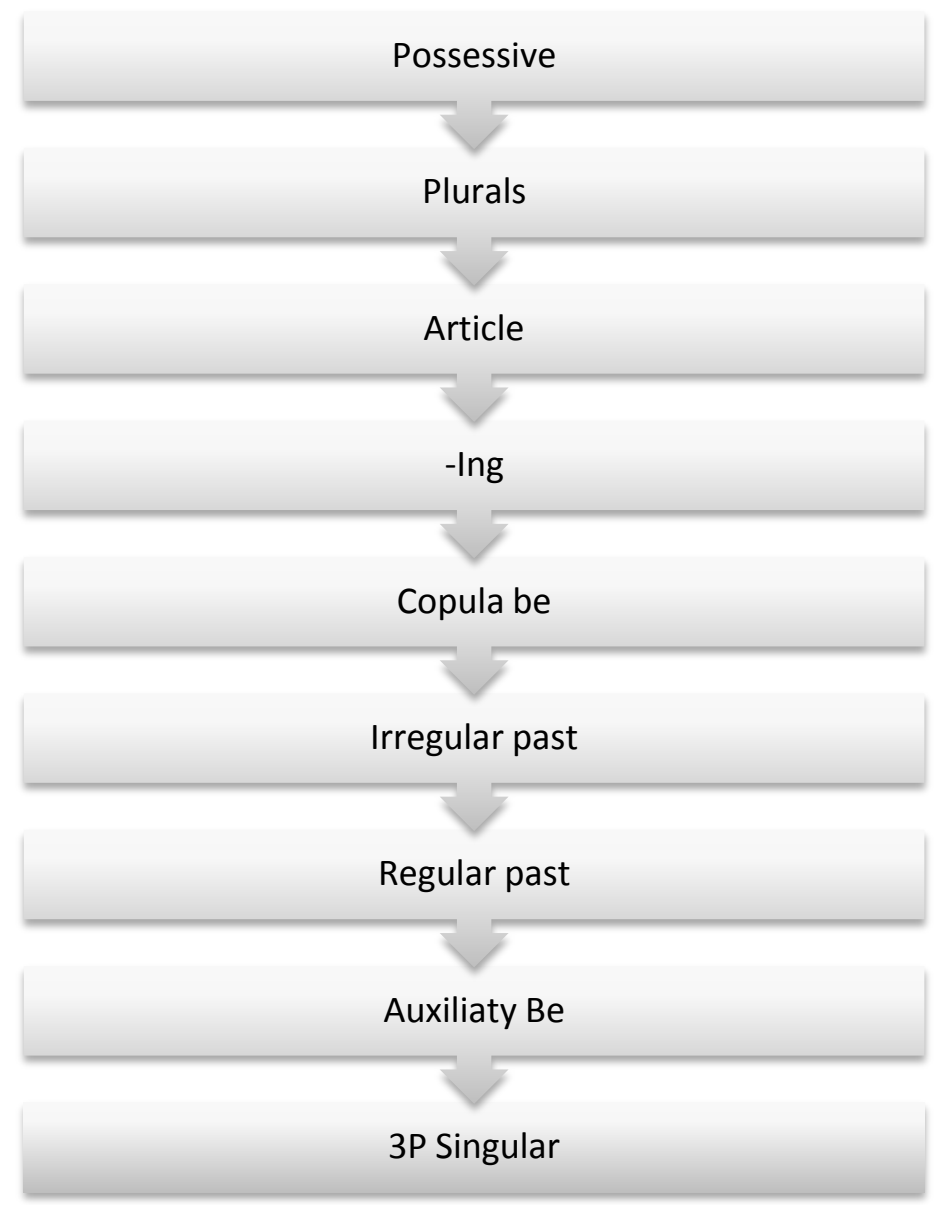

Figure 28. Sequence of morpheme acquisition 2BAC

The book that these students use is Gold by Sally Burgess and Judith Wilson. As we can see throught the syllabus, the 3P Singular morpheme is studied in the first topic although those students do not handle it in a porper way. Copula be an auxiliary be are also studied in the first topic because the topic of this book are divided according to tenses. (present simple and continuous, past simple and continuous, present perfect and so on). The article is studied in the second, fourth and eightth topis. However plurals and possessive are not explained in a inductive way. In other words there are not specific topic which deal with those morpheme forms. Both past regular and irregular are studied in the same topic (topic one). the -Ing form is studied as a isolated entity in topic number four and it is also studied in the first topic because it deals with the present tenses in English.

After comparing syllabus with students' acquisition order we can state that this syllabus does not take into account the morpheme order acquisition, therefore could be necessary to realize that although students study, for instance, the 3P singular in the first topic they are going to fail in when they produce it, in other words, we should know that some mistakes they have are totally normal because they are produced for a reason. The morpheme order acquisition 


\section{Conclusion}

As we have stated several times this study's principal aim was to make a contribution in the morpheme order studies and in the learner corpus research.

This dissertation has been divided into 7 main chapters: the first chapter, i.e., the introduction, was offered a description of our study's aims and it was used to settle our study's topic in its context. The second chapter, that is, Second Language Acquisition and Language Corpora, provides the reader with a literature review of the relevant studies previously conducted and with an overview of the morphemes in English, the language and the learner corpora and finally the pedagogical implication of the basic claim of the MO studies that the morpheme acquisition order should be taken into account when designing the syllabus. In chapter 3, the research questions of this study have been stated. Chapter 4 was dedicated on the description of the methodology used in our study. In that regard, four aspects have been covered: the participants, the materials used, the procedure followed and, finally, the data coding and analysis. Chapter 5 was the largest one, since it contained the presentation and analysis of our study's results; throughout this chapter we can find results that reveal our participants' accuracy level in terms of the correct suppliance of the nine morphemes under examination, after having taken into account several variables such as the level of proficiency, and the course year our participants were in at the moment we conducted the elicitation task and the L2 English proficiency test. This chapter is divided into the general results sub-section and specific results ones. Chapter 6, i.e., the discussion, is an interpretation of the main findings, and finally chapter 7 provides a conclusion where the objectives, positive points of this dissertation and limitations of this study are presented.

As it was stated in the introduction of this study, the aims of this dissertation were the following ones:

- To find out if there were similarities between the morpheme acquisition order of our participants and the one suggested by researchers such as Bailey, Madden \& Krahen (1974) or Brown (1973). However, we should not disregard the fact that in our study we have used a different scoring pattern and elicitation method than the studies conducted by the aforementioned scholars. Nevertheless, we can state that our first objective has been accomplished because we have found similarities in the sequence in which participants acquire the different morphemes. 
- The second aim, that is, the collection and creation of a learner corpus based on the language produced by Spanish L2 English students, has also been achieved. We have created a learner corpus based on 77 samples of learner language produced by students that belonged to five different levels of proficiency (from A1 to $\mathrm{C} 1$ ), had different ages, linguistic background and different school programs. Recall that two of our groups attended a bilingual school.

- Finally, the third aim of this study was to find a pedagogical implication, that is to say, we would like to know if Spanish EFL students follow a certain sequence when they acquire these nine morphemes in order to take it into account when we teach English. . For example when we examine our students we can take into account that some of their mistakes are totally normal because they have to do with the proper acquisition of the language or we could make a scheme of work up taking into account the results we have obtained from this study.

It is important to highlight that this dissertation contributes in a very positive way especially in relation the following aspects: the contribution of the development of learner corpora in Spain; this study is the first attempt to create a learner corpus with secondary students in Andalusia the variety of results could be used in future research, the learner profile provides us with an amount of information which can be used in several ways, that is to say, there are several variables that we could take into account in order to make future researches. The use of the UAM Corpus Tool itself, as I said before, is another important point.

Finally, some limitations of this study must also be taken into account when considering our research: the first one relates to the limited that we had in order to complete a long, complicated and time consuming process, we cannot forget that this study was composed by several parts: we had to get familiar with other Mo studies; we went to different high schools in order to collect the data (placement test results, writing and student profile); after that, we correct the placement test; we also had to transcribe the writings and the students profiles (77 files); in order to work with UAM CORPUS TOOL we had to attend to special seminars our tutors prepared; then we tag 690 morphemes and we analyzed all of them, we also had to study the results we had get and finally we started to write this paper where we describe the whole process. In other word this study include several steps such as the data collection, the correction of the placement test, the transcription of the samples, the data coding, the analyses of the results, the comparison with previous MOS.

The extension of our corpora could also be understood as a limitation of our study. Recall that our learner corpus has samples of learner language produced by our 77 subjects and it should be larger if we 
wished to extend our results to the general attitude of EFL Spanish learners in the acquisition of L2 English. Last but not least, we consider that further research should be conducted regarding the third person singular $-s$ and possessive $-s$ morphemes incorporating extra elicitation tasks that would give enough OC for the use of these functors. This would enable us to study their accuracy levels better. 


\section{References}

Bailey, N., C. Madden and S. D. Krahen 1974. "Is there a "natural sequence" in adult second language learning?' Language Learning, 24: 235-243.

Braun , S. 2005. 'From pedagogically relevant corpora to authentic language learning contents

Brown, R. 1973. A First Language: The Early Stages. Cambridge, Mass: Harvard University Press. Cambridge University Press.

Cook, V. 1993. Linguistics and Second Language Acquisition. New York: St. Martin's Press.

Dulay, H. C. and M. K. Burt 1974. 'Natural sequences in child second language acquisition.' Language Learning, 24: 37-53.

Ellis, R. 1987. 'Interlanguage variability in narrative discourse: Style shifting in the use of the past tense.' Studies in Second Language Acquisitioon 11: 305- 328.

Ellis, R. and G. Barkhuizen 2005. Analysing Learner Language. Oxford: Oxford University Press.

Goldschneider, J. M. and R. M. DeKeyser 2001. 'Explaining the "natural order of L2 morpheme acquisition" in English: A meta-analysis of multiple determinants.' Language Learning, 51: 1-50.

Granger, S. 2004. 'Computer learner corpus research: current status and future prospects' in Connor and Upton (eds.), 123-145.

Granger, S. 2008. 'Learner corpora' in Lüdeling and Kytö (eds.), 259-275.

Hakuta, K. 1976. 'A case study of a Japanese child learning English as a second language.' Language Learning, 26: 321-351.

Krashen, S. 1977. 'Some issues relating to the monitor model.' in Brown, Yorio and Crymes (eds.), 144-158.

Krashen, S. 1977. 'The Monitor Model for adult second language performance.' In: Burt, M., Dulay, H., and Finocchiaro, M. (eds). Viewpoints on English as a Second Language. New York: Regents Publishing.

Krashen, S. 1978. 'Is the "Natural Order" an artefact of the bilingual syntax measure?' Language Learning, 28(1): 187-191.

Kwon, E. 2005. 'The "Natural Order" of morpheme acquisition: A historical survey and discussion of three putative determinants.' Working Papers in TESOL \& Applied Linguistics, 5/1: $1-20$. 
Larsen-Freeman, D. E. 1976. 'An explanation for the morpheme acquisition order of second.' Language Learning, 26: 125-134.

McEnery, A. M. and A. Wilson 2001. Corpus Linguistics. Edinburgh: Edinburgh University Press.

Muñoz, C. 2006. Age and the Rate of Foreign Language Learning. Clevedon, Buffalo: Multilingual Matters.

O'Donnell, M. 2009. 'The UAM Corpus Tool: Software for corpus annotation and exploration' in Bretones Callejas et al. (eds.), 1433-1447.

Tono, Y. 2000. 'A computer learner corpus based analysis of acquisition' in Burnard and McEnery (eds.), 123-133.

Tono, Y. 2003. 'Learner corpora: design, development and applications' in Archer, Rayson, Wilson and McEnery (eds.), 800-809.

Tono, Y. 2005. Corpus-based SLA research: State of the Art of Learner Corpus Studies. Tokio: Kurosio Publishers. 


\section{Appendices}

Appendix 1. Learner profile form

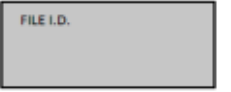

Fecha:

\section{INFORMACIÓN PERSONAL}

-TUS INICIALES

-TU NICK

EDAD

-SEXO: $\square$ Hombre $\square$ Mujer

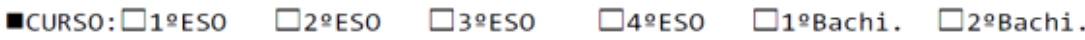

$\square$ PCPI $\square$ Grado administrativo $\square$ otro

- INSTITUTO DONDE ESTÁs ESTUdIANDO:

\section{INFORMACIÓN LINGÜISTICA}

- Lengua materna: $\square$ español $\square$ otra (indicar):

- Lengua materna de tu padre: $\square$ español $\square$ otra (indicar):

- Lengua materna de tu madre: $\square$ español $\square$ otra (indicar):

- Lengua(s) que hablas en casa: $\square$ español $\square$ otras (indicar):

Edad a la que empezaste a aprender inglés

¿ ¿Cuál crees tú que es tu nivel de inglés?

\begin{tabular}{|c|c|c|c|}
\hline $\begin{array}{l}\text { SPEAKING: } \\
\text {-Principiante bajo (A1) } \\
\text {-Principiante alto (A2) } \\
\text { qIntermedio bajo (B1) } \\
\text { qIntermedio alto (B2) } \\
\text { DAvanzadobajo (C1) } \\
\text { DAvanzado alto (C2) }\end{array}$ & 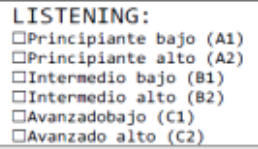 & 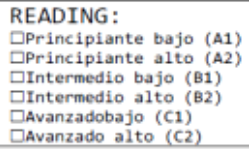 & 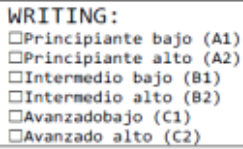 \\
\hline
\end{tabular}

घ ¿Estás aprendiendo otro idioma además del inglés? $\square$ sí $\square$ No Si tu respuesta es Sí, ¿Cuál?

- Nota del curso pasado (a rellenar por el profesor de inglés):

\section{EXPOSICIÓN LINGÜISTICA}

@ ¿Has hecho alguna estancia en un país de habla inglesa? $\square$ si $\square$ No Si tu respuesta es Sí, ¿dónde?

¿cuándo?

¿cuántas semanas o meses estuviste alli?

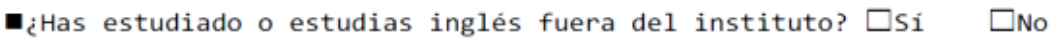
$\mathrm{Si}$ has contestado Sí, ¿en quẻ año y cuảnto tiempo (semanas/meses)?

- ¿Haces algo fuera del colegio relacionado con el inglés? (ej: ver películas en inglés, leer internet en inglés, etc.) $\square$ sí $\square$ No

Especifica:

[Estás en algún programa de bilingüismo en el Instituto? $\square$ si

Si tu respuesta es Si, ¿en qué curso empezaste el bilingüismo? ¿Qué asignaturas bilingües tienes?

¿Cuántas horas semanales de inglés tienes en esas asignaturas?

- Consentimiento: $\square$ marca aqui para dar el consentimiento de que tus datos sean usados con fines de investigación sobre el aprendizaje del inglés. Esto No es un examen. Todos tus datos serán anónimos y tratados confidencialmente. Gracias por tu colaboración. 


\section{English}

\section{Unlimited Placement test}

\section{Written test}

- Choose the best answer for each question.

- Stop when the questions become too difficult.

- Spend no more than 40 minutes on the test.

1 Where__from?

I'm from Russia.
A you are
B you
$\mathrm{C}$ are you

2 We have house in Moscow.
A any
B a
$\mathrm{C}$ an

3 I have two , a boy and a girl.
A sons
B daughters
C children

4 I work in a I'm a doctor.
A hospital
B hotel
C supermarket

5 This is my brother. name's Paul.
A Her
B His
C He's

6 five people in my family.
A They are
B There is
C There are

7 I get up 7 o'clock in the morning.
A for
$B$ at
$C$ in

8 I like apples, but I bananas.
A don't like
B like
C do like

9 Excuse me, speak French?
A do you
B you do
C you

10 How much are shoes?
A this
$B$ these
C that 
11 Where are my glasses?

They're the table.
$A$ at
$B$ on
$C$ in

12 My sister tennis very well.
A plays
B play
C playing

13 I usually go to work train.
$A$ on
B with
C by

14 I don't see my parents very often they live in South Africa.
A so
$B$ but
C because

15 Rosie stayed home yesterday afternoon.
$A$ in
$B$ at
C to

16 Last night to the cinema.
A went
B did go
C was

17 The is quite expensive but the food there is excellent.
A film
B restaurant
C book

18 Do you want to listen to music or TV?
A see
B look
C watch

19 were you at the weekend?

I was in Scotland.
A When
B Where
C What

20 you have a good time at the party?

Yes, it was fun.
A Did
B Were
C Had

21 Are you English teacher?
A Maria
B Marias'
C Maria's

22 Bob will meet at the airport.
$A$ us
B we
C our

23 I'm going to a concert tonight. you like to come?
A Do
B Are
C Would 
Sure. Here you are.
A Could I
B Could you
C DoI

25 I like this apartment but the is too expensive for me.
A money
B rent
C cost

26 Excuse me, how do I to the bus station?
A come
$B$ get
C arrive

27 Do you sell stamps?

Yes, we do. How do you want?
A any
B many
C much

28 Sorry l'm so late.

That's
A OK
B great
C right

29 l'd like milk in my coffee, please.
A some
$B$ any
$\mathrm{C}$ a

30 a bus stop near my flat.
A It's
B Here's
C There's

31 Is this a good time to talk?

Sorry, no. I dinner.
A cook
B am cooking
C cooking

32 I think cycling is more dangerous driving.
$A$ as
B like
C than

$33 \mathrm{We}$ going to the theatre next Saturday.
A will
B do
C are

34 meet for coffee some time soon.
A Let's
B Do you
C Shall they

35 Kamal has got a holiday home near sea.

A a

B the

C some 
36 If you've got a headache, you go home.
A should
B did
C had

37 ever been to New York?
A Have you
B Are you
C Did you

38 I only get about five hours' sleep a night.

That's not
$A$ enough
B lot
C too much

39 Did Amina finish the report?

No. She it tomorrow.
A finishes
$B$ is going to finish
C finished

40 Paula loves working with children.
A very
$B$ really
C much

41 Is Ottawa the capital of Canada? I think
$A$ is
B yes
C so
D right

42 We never a television when I was a child.
A have had
B hadn't
C had
D didn't have

43 We paid the restaurant bill credit card.
A to
B with
C on
D by

44 The last time Joanna was in Paris.
A have seen
B saw
C see
D was seeing

45 If you money from a friend, you should always pay it back promptly.
A borrow
B earn
C spend
D lend

46 Can I make myself a cup of coffee?

Of course. You to ask.
A haven't
B mustn't
C needn't
D don't have

$47 \quad 1$ a lot of sport in my free time.
A do
B practise
C make
D exercise

48 anywhere interesting recently?
A Do you go
B Have you been
C Are you going
D Will you go 
49 It's Walter's birthday on Friday. $\mathrm{He}$ be 30, I think
A should
B can
C will
D shall

50 Learning the piano isn't as difficult learning the violin.
A like
B so
$C$ than
$\mathrm{D}$ as

51 If the weather bad tomorrow, we can go to a museum.
A will be
B was
$C$ is
D would be

52 About a billion cans of Coca-Cola drunk around the world every day.
$A$ is
$\mathrm{B}$ are
C was
D were

53 My mum's not very well.

Oh,
A it doesn't matter
B I do apologise
C sorry to hear that
D not bad, thanks.

54 Hans isn't here. He to see his grandmother. He'll be back tomorrow.
A has gone
B had been
C has been
D had gone

55 Would you mind changing my appointment? time on Friday is fine.
A Next
B All the
C Every
D Any

56 When I was a child, I climb the wall and jump into our neighbours' garden.
A would
B did
C have
D used

57 Have you finished the wall yet?
A paint
B to paint
C painting
D painted

58 Can you help me? I've tried hotel in the city and can't find a room.
A many
B any
C every
D all

$59 \quad$ Lena used to find work boring she became a nurse.
A unless
B until
$C$ if
D since

60 If $\mid$ closer to my office, I could walk to work.
A lived
$B$ would live
C had lived
D live

$61 \quad$ । outside the cinema when suddenly a police car arrived.
A stood
B was standing
$C$ have stood
D am standing 
62 Shall we go to The Riceboat for dinner?

It be fully booked. They're sometimes busy on a Monday.
A will
B may
C can
D must

63 We've come back from a trip to India. It was amazing.
A already
B yet
C just
D only

64 I've got to be at work in five minutes.

Don't worry, I you a lift if you want.
A give
$B$ am giving
C 'll give
D 'm going to give

65 My doctor advised me more exercise.
A take
B taking
C having taken
D to take

66 I couldn't up with the noise in the city, so we moved to the countryside.
A put
B live
C set
D take

67 There's no name on this dictionary. It be mine then. Mine's got my name on the front.
A might not
B mustn't
C won't
D can't

68 Julia married since she was 20 .
$A$ is
B was
C has been
$D$ is being

69 Don't worry if I late tonight. l'm going to the gym after work.
A am
B will be
C would be
D was

70 I've got a terrible headache, and it won't go away. Have you tried some aspirin?
A to take
B take
C took
D taking

71 Boxing is a sport requires a lot of speed and fitness.
A it
$B$ that
C what
D where

72 Jon working on this project for a couple of months so he hasn't made much progress yet.
$A$ is only
$B$ has only been
C was only
D had only been

73 I was wondering I could ask you some questions.

Sure, go ahead.
A what
$B$ if
C that
D how 
74 What clothes should I pack for a trip to Boston?

Well, it depends the time of year that you go.
$A$ on
B with
C up
D to

75 I've finished this salad and I'm still hungry. ordered something more filling.
A must have
B would have
C should have
D may have

76 Do you ever ask your neighbours to do favours you?
A for
B to
C with
D about

77 Some married couples seem to get more over time.
A alike
B same
C like
$D$ equal

78 I don't know how much this card costs. The price label's off.
A gone
B taken
C done
D come

79 Ben got the job because he a very good impression at his interview.
A made
B did
C put
D took

80 Salsa music always me of my trip to Cuba.
A remembers
B realises
C recognises
D reminds

81 I to be picking Tom up at the station but l've lost my keys.
A am supposed
$B$ am requested
C am intended
D am obliged

82 How about going to Colours nightclub? There's no I'm going there. It's awful!
A hope
B way
C time
D opportunity

83 By the age of 18, I not to go to university.
A had decided
B decided
C have decided
D was deciding

84 I'm afraid your car repaired before next week.
A hasn't been
B wasn't
C wouldn't be
D can't be

85 The amount of organically grown food on sale has enormously in recent years.
A raised
B lifted
C increased
D built

86 Can you believe it? A woman has been for hacking into the computer of her online virtual husband.
A accused
B suspended
C arrested
D suspected 
87 You may borrow my laptop you promise to look after it.
A unless
$B$ in case
C as long as
D although

88 It's a huge painting. It taken ages to complete.
A must have
B can't have
C should have
D won't have

$89 \quad$ Pierre tends to put dealing with problems, rather than dealing with them immediately.
A down
B off
C over
D away

90 If the taxi hadn't stopped for us, we standing in the rain.
A were still
B would still be
C are still
D will still be

91 My mother's Italian, so the language has been quite easy for me.
A to learn
B learn
$\mathrm{C}$ having learned
D learning

92 I had the talent, I still wouldn't want to be a movie star.
A In case
B Even if
C Provided that
D However much

93 The factory workers threatened on strike if they didn't get a pay rise.
A going
B to go
C that they go
D to have gone

94 I was about to go to sleep when it to me where the missing keys might be.
A remembered
B happened
C appeared
D occurred

95 There's going to be a new department at work. They've asked me to it up.
A take
B set
C put
D bring

96 If the film is a success, the director will get most of the credit.
A big
B high
C large
D good

97 By the end of today's seminar I will to each of you individually.
A speak
B have spoken
C be speaking
D have been speaking

98 This is a photo of my little sister ice cream on the beach.
$A$ eat
B eating
C was eating
D having eaten

99 Our students take their responsibilities very
A considerably
B thoroughly
C seriously
D strongly

100 Pia was delighted with the birthday present.
A very
B completely
C fairly
D absolutely 


\section{FROG WHERE ARE YOU?}

Glossary: Dog (perro), frog (rana), boy (nino), bed (cama), vase (vaso), floor (suelo), look at (mirar a), smell (oler), day (dia), night (noche), sleef (dormir), escape (escapar), worried (preocupado), look for (buscar), shout (gritar), forest (bosque), bee (abeja), rock (roca), hold (sostener), branch (rama) deer (ciervo), drop (caer), push (empujar), fall (caer), river (rio), water (agua), trunk (tronco), find (encontrar), family (familia), leave (dejar), hand (mano) and wave qoodbve (decir adios).

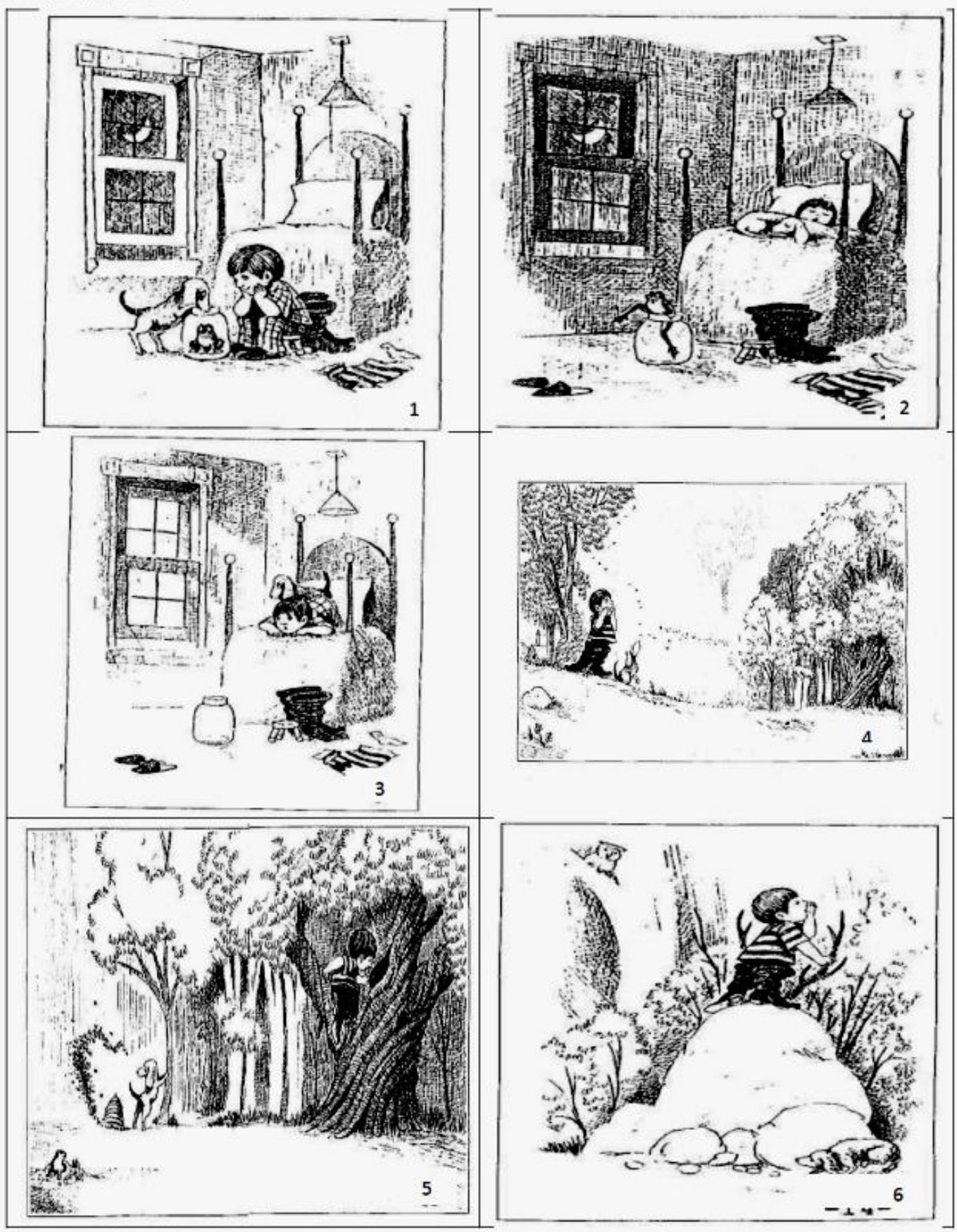




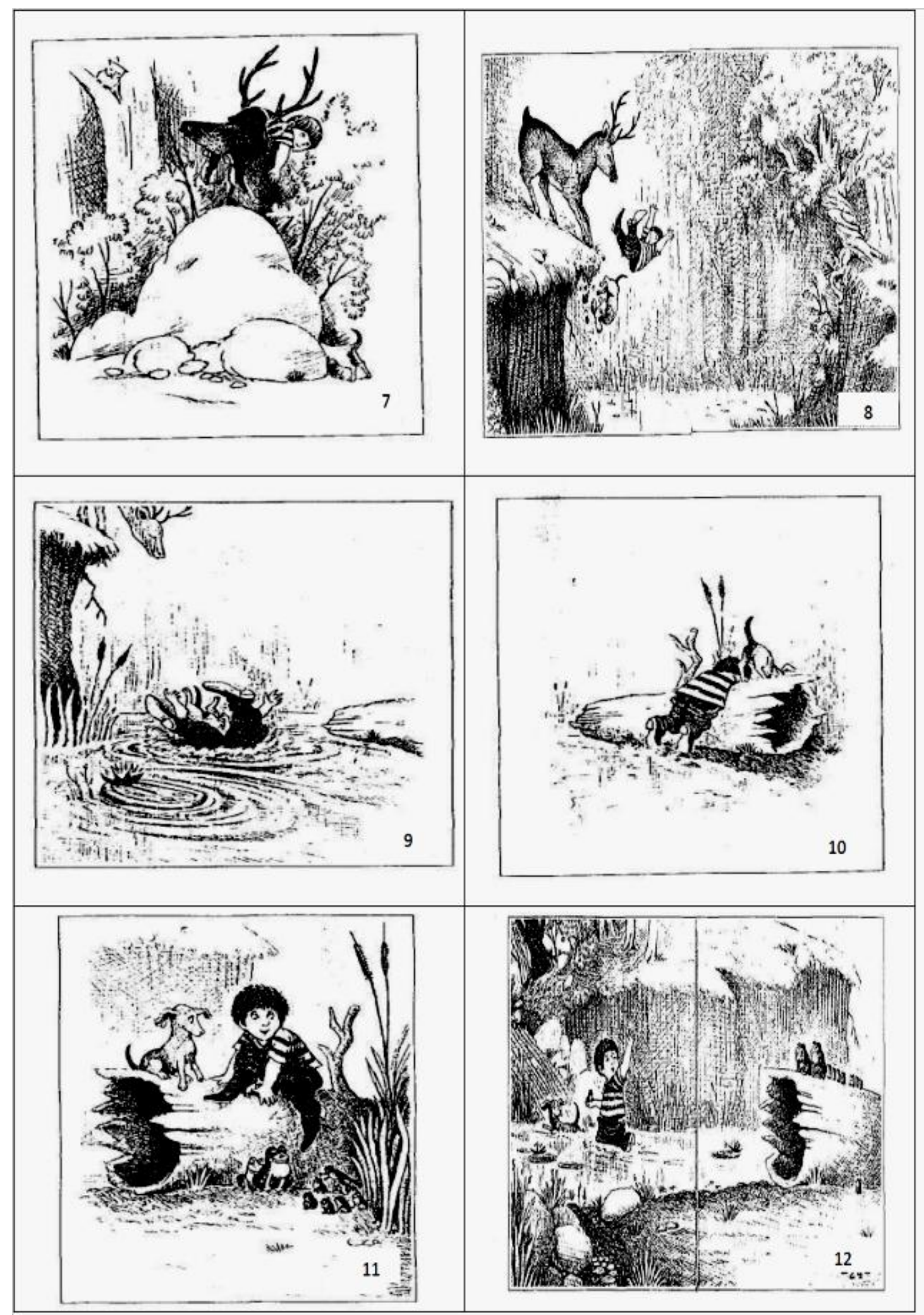


Appendix 4. Elicitation task sheet

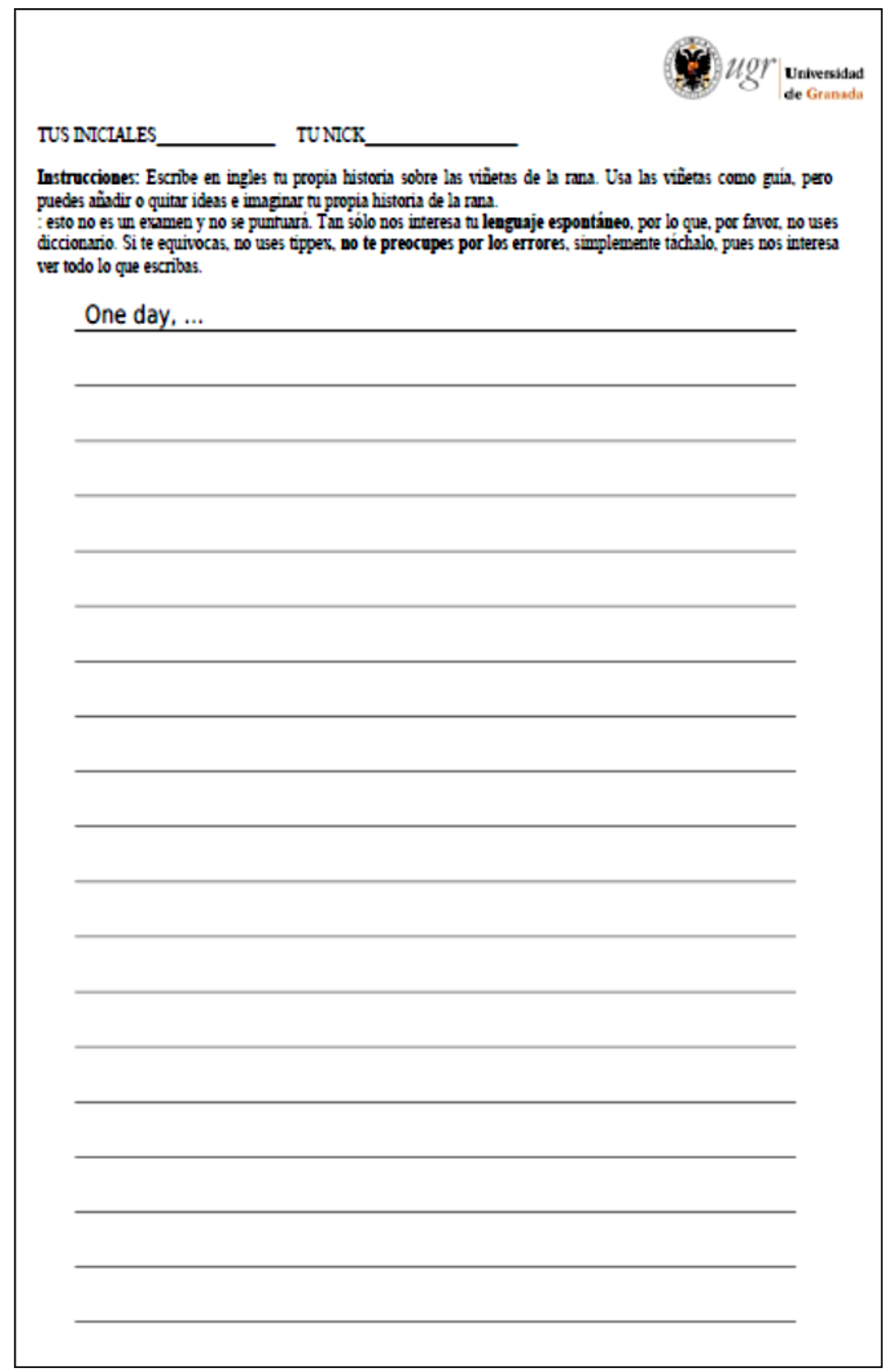




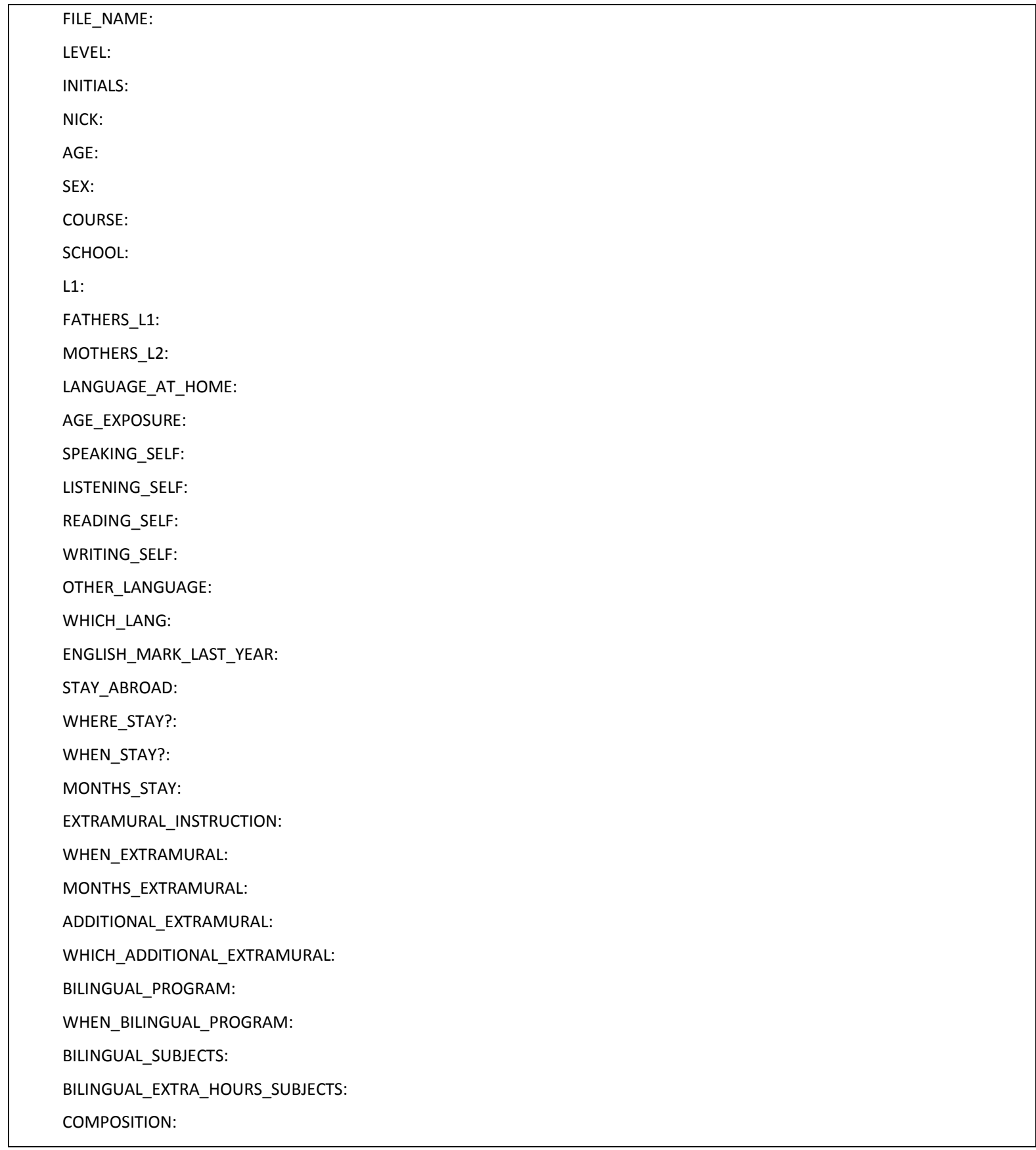


FILE_NAME: A1_2ESO_13_CAR_ADD_RLF

LEVEL: A1

INITIALS:RLF

NICK: ANTO

AGE:13

SEX:MALE

COURSE:2 ESO

SCHOOL: CARTUJA

L1: SPANISH

FATHERS_L1: SPANISH

MOTHERS_L2: SPANISH

LANGUAGE_AT_HOME: SPANISH

AGE_EXPOSURE: 10

SPEAKING_SELF:A1

LISTENING_SELF: A1

READING_SELF:A1

WRITING_SELF: A1

OTHER_LANGUAGE: NO

WHICH_LANG:

ENGLISH_MARK_LAST_YEAR:5

STAY_ABROAD: NO

WHERE_STAY?:

WHEN_STAY?:

MONTHS_STAY:

EXTRAMURAL_INSTRUCTION: NO

WHEN_EXTRAMURAL:

MONTHS_EXTRAMURAL:

ADDITIONAL_EXTRAMURAL: NO

WHICH_ADDITIONAL_EXTRAMURAL:

BILINGUAL_PROGRAM: NO

WHEN_BILINGUAL_PROGRAM:

BILINGUAL_SUBJECTS:

BILINGUAL_EXTRA_HOURS_SUBJECTS:

COMPOSITION: 
One day, at night a find frog. In vase a water at escape a night. Money look at floor he wasn't frog. Boy worried can look for a forest and bee. Find and catch at escape at rock, branch, drop, river. Boy drop river. Boy shout frog.

FILE_NAME: A1_2ESO_13_CAR_ADD_ROS

LEVEL: A1

INITIALS:ROS

NICK: RUBENSIYO

AGE:13

SEX:MALE

COURSE:2 ESO

SCHOOL: CARTUJA

L1: SPANISH

FATHERS_L1: SPANISH

MOTHERS_L2: SPANISH

LANGUAGE_AT_HOME: SPANISH

AGE_EXPOSURE: 10

SPEAKING_SELF:A1

LISTENING_SELF: A1

READING_SELF:A1

WRITING_SELF: A1

OTHER_LANGUAGE: NO

WHICH_LANG:

ENGLISH_MARK_LAST_YEAR:5

STAY_ABROAD: NO

WHERE_STAY?:

WHEN_STAY?:

MONTHS_STAY:

EXTRAMURAL_INSTRUCTION:NO

WHEN_EXTRAMURAL:

MONTHS_EXTRAMURAL:

ADDITIONAL_EXTRAMURAL: NO

WHICH_ADDITIONAL_EXTRAMURAL:

BILINGUAL_PROGRAM: NO

WHEN_BILINGUAL_PROGRAM:

BILINGUAL_SUBJECTS: 
BILINGUAL_EXTRA_HOURS_SUBJECTS:

COMPOSITION:

One day, a boy and dog look at frog. The frog escape and the boy look for and look far. The boy worried look for the frog in the forest evety wear in the trunk... the boy was on the rock look for the frog. was deer, push a boy and water. the boy and dog left in the trunk

FILE_NAME: A1_2ESO_13_CAR_ADD_VPS

LEVEL: A1

INITIALS:VPS

NICK: VERÓNICA.P

AGE:14

SEX:FEMALE

COURSE:2 ESO

SCHOOL: CARTUJA

L1: SPANISH

FATHERS_L1: SPANISH

MOTHERS_L2: SPANISH

LANGUAGE_AT_HOME: SPANISH

AGE_EXPOSURE: 11

SPEAKING_SELF:A1

LISTENING_SELF: A1

READING_SELF:A1

WRITING_SELF: A1

OTHER_LANGUAGE: NO

WHICH_LANG:

ENGLISH_MARK_LAST_YEAR:5

STAY_ABROAD: NO

WHERE_STAY?:

WHEN_STAY?:

MONTHS_STAY:

EXTRAMURAL_INSTRUCTION:NO

WHEN_EXTRAMURAL:

MONTHS_EXTRAMURAL:

ADDITIONAL_EXTRAMURAL: NO

WHICH_ADDITIONAL_EXTRAMURAL:

BILINGUAL_PROGRAM: NO 


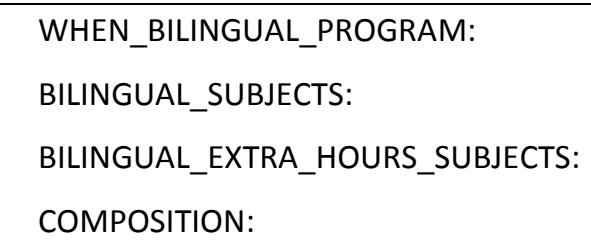
\$_UNR_searcher \$_INS_look \$_INR_for floor, rock look at branch and trunk, a boy bv worried, look for for day and night. He found deer and \$_RWU_drop push and drop water the river and find family frong rana. and wave goodbye the dog and boy.

FILE_NAME: A1_2ESO_13_CAR_ADD_TMH

LEVEL: A1

INITIALS:TMH

NICK: PATY

AGE:14

SEX:MALE

COURSE:2 ESO

SCHOOL: CARTUJA

L1: SPANISH

FATHERS_L1: SPANISH

MOTHERS_L2: SPANISH

LANGUAGE_AT_HOME: SPANISH

AGE_EXPOSURE: 11

SPEAKING_SELF:A1

LISTENING_SELF: A1

READING_SELF:A1

WRITING_SELF: A1

OTHER_LANGUAGE: NO

WHICH_LANG:

ENGLISH_MARK_LAST_YEAR:5

STAY_ABROAD: NO

WHERE_STAY?:

WHEN_STAY?:

MONTHS_STAY:

EXTRAMURAL_INSTRUCTION:NO

WHEN_EXTRAMURAL:

MONTHS_EXTRAMURAL: 


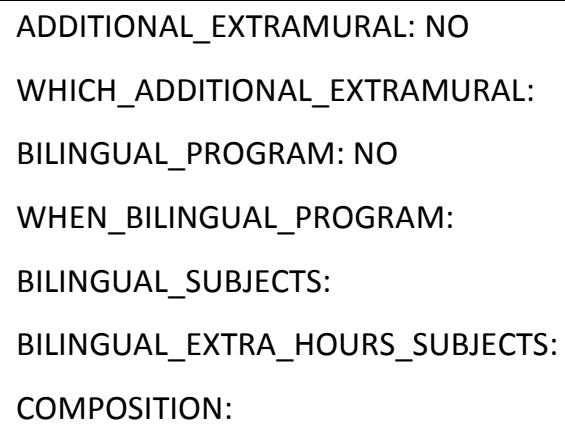

One day, a boy was on the floor. He had a frog. The frog escape \$_INS_at night. The boy was worried. The boy was looking four, the boy shout in the forest. The boy looking foor the frog lookin. The boy was in one rock. The deer push a boy a dogs the river. The boy a the dogs was in trunk. The boy finding the frog. The frog was family the boy leaving the frog the boy a the doog and wave goodbye a family the frog.

FILE_NAME: A2_2BAC_17_CAR_ADD_AAC

LEVEL: A2

INITIALS:AAC

NICK: RUBIA

AGE:17

SEX:FEMALE

COURSE:2 BAC

SCHOOL: CARTUJA

L1: SPANISH

FATHERS_L1: SPANISH

MOTHERS_L2: SPANISH

LANGUAGE_AT_HOME: SPANISH

AGE_EXPOSURE: 10

SPEAKING_SELF:A2

LISTENING_SELF: A2

READING_SELF:A2

WRITING_SELF: A2

OTHER_LANGUAGE: YES

WHICH_LANG: FRENCH

ENGLISH_MARK_LAST_YEAR:6

STAY_ABROAD: NO

WHERE_STAY?:

WHEN_STAY?:

MONTHS_STAY: 
EXTRAMURAL_INSTRUCTION:NO

WHEN_EXTRAMURAL:

MONTHS_EXTRAMURAL:

ADDITIONAL_EXTRAMURAL: NO

WHICH_ADDITIONAL_EXTRAMURAL:

BILINGUAL_PROGRAM: NO

WHEN_BILINGUAL_PROGRAM:

BILINGUAL_SUBJECTS:

BILINGUAL_EXTRA_HOURS_SUBJECTS:

\section{COMPOSITION:}

One day, Tony and Rizy \$_RWU_your her dog, playing \$_RWU_wh with one frog. Tony and Rizy slipping together in the bed. In the night, the frog escape on the vase and she go it. On the morning, Tony look at the floor but the frog isn't. Tony and Rizy are worried and go look for in the forest. Tony shout while Rizy see bees. Tony see one rock and think that up see very good. While see in the rock one deer surprised. The deer push Tony and the and Rizy fall to the river. Together swimming on the river more time. Rizy find one trunk. Tony and Rizy go out the river and see \$_RWU_family the frog family. When Tony see that, he decided leave the frog with her family and go out at her house with Rizy

FILE_NAME: A2_2BAC_17_CAR_ADD_LDL

LEVEL: A2

INITIALS:LAD

NICK: LAU

AGE:17

SEX:FEMALE

COURSE:2 BAC

SCHOOL: CARTUJA

L1: SPANISH

FATHERS_L1: SPANISH

MOTHERS_L2: SPANISH

LANGUAGE_AT_HOME: SPANISH

AGE_EXPOSURE: 10

SPEAKING_SELF:A2

LISTENING_SELF: A2

READING_SELF:A2

WRITING_SELF: A2

OTHER_LANGUAGE: YES

WHICH_LANG: FRENCH 
ENGLISH_MARK_LAST_YEAR:7

STAY_ABROAD: NO

WHERE_STAY?:

WHEN_STAY?:

MONTHS_STAY:

EXTRAMURAL_INSTRUCTION:NO

WHEN_EXTRAMURAL:

MONTHS_EXTRAMURAL:

ADDITIONAL_EXTRAMURAL: NO

WHICH_ADDITIONAL_EXTRAMURAL:

BILINGUAL_PROGRAM: NO

WHEN_BILINGUAL_PROGRAM:

BILINGUAL_SUBJECTS:

BILINGUAL_EXTRA_HOURS_SUBJECTS:

COMPOSITION:

One day, a boy find a frog in the forest and he, \$_INS_his dog and frog go to the \$_UNR_i bed and the frog go out of his vase in the night while the sleeping and she escape. The boy worried for the frog go to the forest and looked for and shouted and shouted in the forest and he up in a rock, in a \$_RWU_tree branch of the tree, he find a deer, \$_RWU_push this push and the boy fall in the river, he $\$ \_U N R \_\dot{c}$ hold a trunk and find $\$ \_U N R \_\dot{ }$ a frog with her family, the boy leave in the forest with her family and the two be happy and the boy say wave goosbye.

FILE_NAME: A2_2BAC_17_CAR_ADD_MAG

LEVEL: A2

INITIALS:MAG

NICK: MAGI

AGE:17

SEX:MALE

COURSE:2 BAC

SCHOOL: CARTUJA

L1: SPANISH

FATHERS_L1: SPANISH

MOTHERS_L2: SPANISH

LANGUAGE_AT_HOME: SPANISH

AGE_EXPOSURE: 8

SPEAKING_SELF:A1 
LISTENING_SELF: A1

READING_SELF:A2

WRITING_SELF: A1

OTHER_LANGUAGE: YES

WHICH_LANG: FRENCH

ENGLISH_MARK_LAST_YEAR:6

STAY_ABROAD: NO

WHERE_STAY?:

WHEN_STAY?:

MONTHS_STAY:

EXTRAMURAL_INSTRUCTION:NO

WHEN_EXTRAMURAL:

MONTHS_EXTRAMURAL:

ADDITIONAL_EXTRAMURAL: NO

WHICH_ADDITIONAL_EXTRAMURAL:

BILINGUAL_PROGRAM: NO

WHEN_BILINGUAL_PROGRAM:

BILINGUAL_SUBJECTS:

BILINGUAL_EXTRA_HOURS_SUBJECTS:

COMPOSITION:

One day, he went to sleep with his dog in his bed while the frog escaped to the base. When the child woke up he saw that his frog have scaped. When he and his dog went to look for him. They shouted but anyone anywhere. The bees followed them but they escaped. Then they found a deer, it pushed them and they dropped and find the frog with his family.

FILE_NAME: A2_2BAC_17_CAR_ADD_RMM

LEVEL: A2

INITIALS:RMM

NICK: MEMAR

AGE:17

SEX:FEMALE

COURSE:2 BAC

SCHOOL: CARTUJA

L1: SPANISH

FATHERS_L1: SPANISH

MOTHERS_L2: SPANISH 


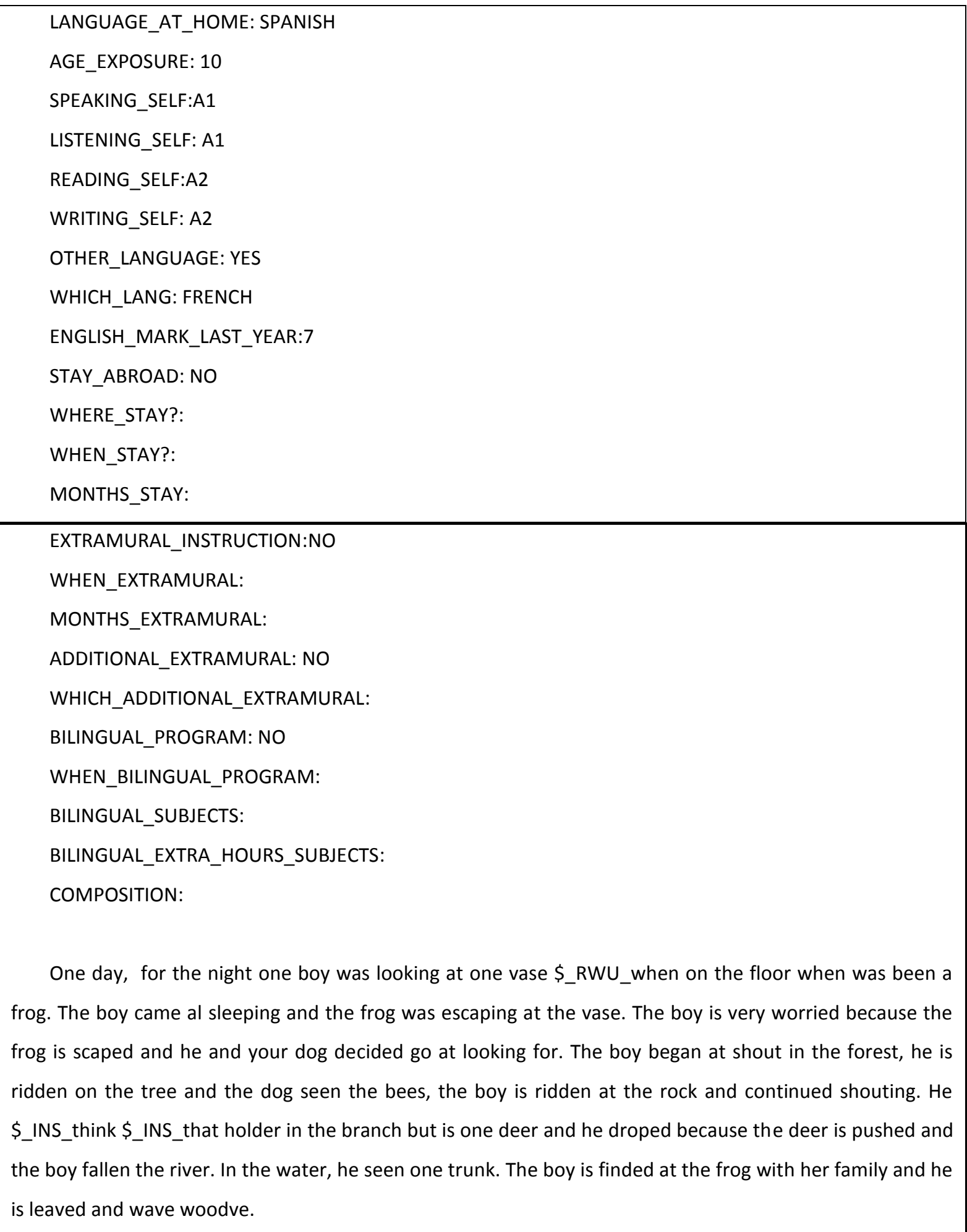

FILE_NAME: A2_2BAC_17_CAR_ADD_RVC

LEVEL: A2

INITIALS:RVC

NICK: CICUTILLA

AGE:17 
SEX:FEMALE

COURSE:2 BAC

SCHOOL: CARTUJA

L1: SPANISH

FATHERS_L1: SPANISH

MOTHERS_L2: SPANISH

LANGUAGE_AT_HOME: SPANISH

AGE_EXPOSURE: 10

SPEAKING_SELF:A1

LISTENING_SELF: A1

READING_SELF:A2

WRITING_SELF: A2

OTHER_LANGUAGE: YES

WHICH_LANG: FRENCH

ENGLISH_MARK_LAST_YEAR:6

STAY_ABROAD: NO

WHERE_STAY?:

WHEN_STAY?:

MONTHS_STAY:

EXTRAMURAL_INSTRUCTION:NO

WHEN_EXTRAMURAL:

MONTHS_EXTRAMURAL:

ADDITIONAL_EXTRAMURAL: NO

WHICH_ADDITIONAL_EXTRAMURAL:

BILINGUAL_PROGRAM: NO

WHEN_BILINGUAL_PROGRAM:

BILINGUAL_SUBJECTS:

BILINGUAL_EXTRA_HOURS_SUBJECTS:

COMPOSITION:

One day, at night a boy and dog look at frog. The boy sleep the frog escape. \$_RWU_day The following day look for frog. The boy and dog worried shout in the forest. The boy in the branch the dog look a bee. The boy on the rock shout a frog. The boy fall in the deer. The deer push a boy pog the water. The boy leave the water at dog. The boy on the hand a frog and wave goodbye baud.

FILE_NAME: A2_2BAC_17_CAR_ADD_EMP

LEVEL: A2

INITIALS:EMP 
NICK: ESTEFI

AGE:18

SEX:FEMALE

COURSE:2 BAC

SCHOOL: CARTUJA

L1: SPANISH

FATHERS_L1: SPANISH

MOTHERS_L2: SPANISH

LANGUAGE_AT_HOME: SPANISH

AGE_EXPOSURE: 11

SPEAKING_SELF:A1

LISTENING_SELF: A2

READING_SELF:A1

WRITING_SELF: A2

OTHER_LANGUAGE: YES

WHICH_LANG: FRENCH

ENGLISH_MARK_LAST_YEAR:7

STAY_ABROAD: NO

WHERE_STAY?:

WHEN_STAY?:

MONTHS_STAY:

EXTRAMURAL_INSTRUCTION:NO

WHEN_EXTRAMURAL:

MONTHS_EXTRAMURAL:

ADDITIONAL_EXTRAMURAL: NO

WHICH_ADDITIONAL_EXTRAMURAL:

BILINGUAL_PROGRAM: NO

WHEN_BILINGUAL_PROGRAM:

BILINGUAL_SUBJECTS:

BILINGUAL_EXTRA_HOURS_SUBJECTS:

COMPOSITION:

One day, one boy was look at his dog, the dog was smell at frog. That night, the frog escape. The next day, the boy was worried and he look for at frog. The boy and god look for in the forest and shout at the frog. The boy find a deer and the deer push at boy. The boy fall in the river. The boy and dog find at frog with family. The boy hold frog in his hand and wave woobie at the family the frog.

FILE_NAME: A2_2BAC_18_CAR_ADD_LAL 
LEVEL: A2

INITIALS:LAL

NICK: LAURA AGUILAR

AGE:18

SEX:FEMALE

COURSE:2 BAC

SCHOOL: CARTUJA

L1: SPANISH

FATHERS_L1: SPANISH

MOTHERS_L2: SPANISH

LANGUAGE_AT_HOME: SPANISH

AGE_EXPOSURE: 10

SPEAKING SELF:A1

LISTENING_SELF: A1

READING_SELF:A2

WRITING_SELF: A2

OTHER_LANGUAGE: YES

WHICH_LANG: FRENCH

ENGLISH_MARK_LAST_YEAR:6

STAY_ABROAD: NO

WHERE_STAY?:

WHEN_STAY?:

MONTHS_STAY:

EXTRAMURAL_INSTRUCTION:NO

WHEN_EXTRAMURAL:

MONTHS_EXTRAMURAL:

ADDITIONAL_EXTRAMURAL: NO

WHICH_ADDITIONAL_EXTRAMURAL:

BILINGUAL_PROGRAM: NO

WHEN_BILINGUAL_PROGRAM:

BILINGUAL_SUBJECTS:

BILINGUAL_EXTRA_HOURS_SUBJECTS:

COMPOSITION:

One day, Une boy \$_UNR_i boy was find a the frog. The boy was began a her house the frog because it night the frog escape when boy was sleeped. When the boy woke up, he seed the the \$_RWU_forg frog \$_RWU_don't escape and the boy \$_UNR_i was worried. The last day the boy decided look for a the frog and he go to the montain and \$_UNR_i begin shout. The boy clim the rock, run, shout but he don't find. 
The forg. He hold in the branch suddenly a deer he push the boy a \$_UNR_i river. the boy \$_UNR_¿ felt the water. Suddenly the children is was found the family frog and the boy decided leave to free the frog for the it can live with you family.

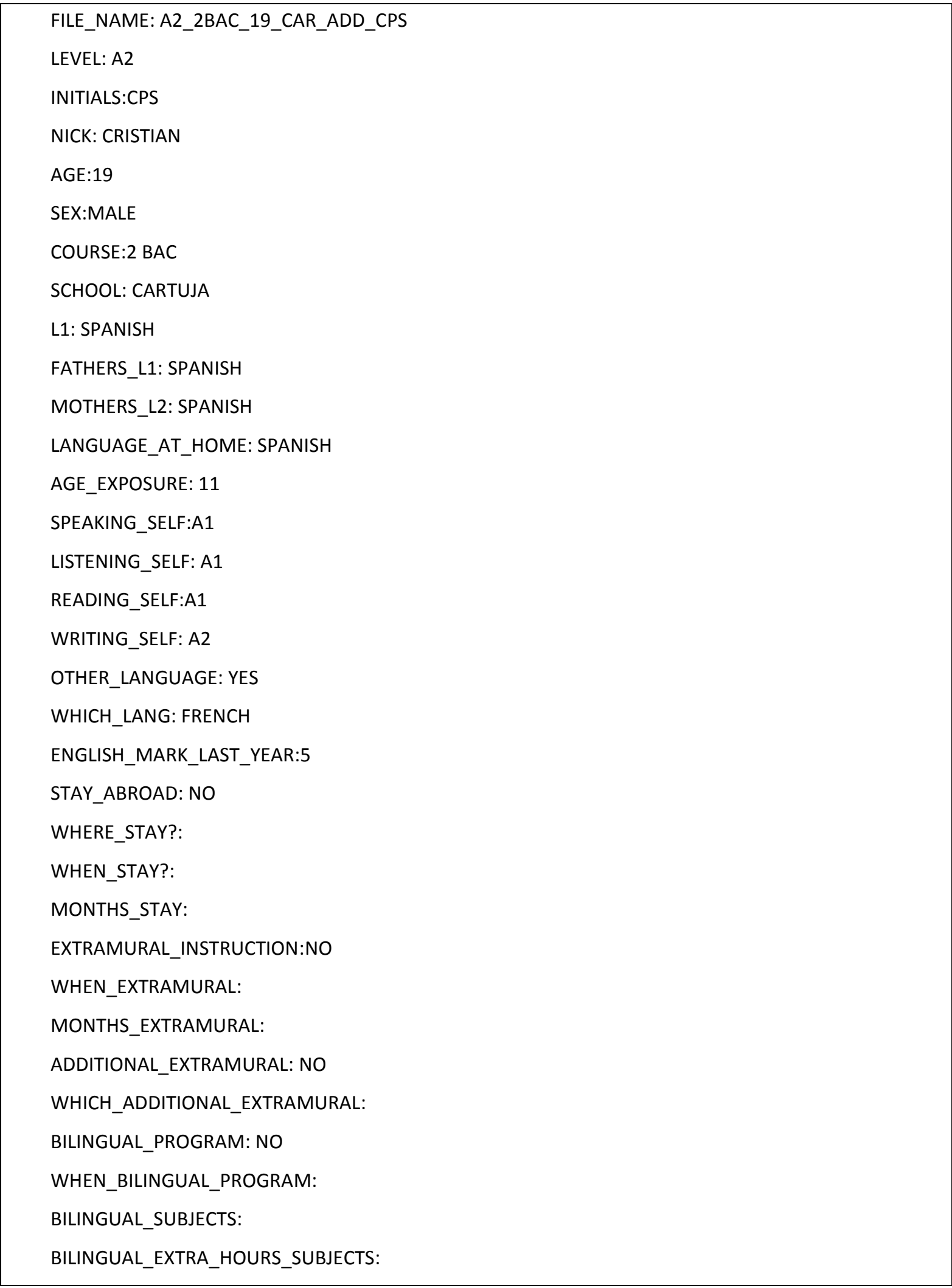




\section{COMPOSITION:}

One day, my dog and I saw the frog that are in water and the frog saw the boy and dog. I are sleep in the bed but night and the frot is escape. The boy and dog are worried and are looking for the frog in the trunk, river, forest. Before they look for in the forest think that the frog are in the river and the frog are in the trunk \$_UNR_i in the river.

FILE_NAME: A2_2BAC_19_CAR_ADD_MCA

LEVEL: A2

INITIALS:MCA

NICK: MARTITA

AGE:19

SEX:FEMALE

COURSE:2 BAC

SCHOOL: CARTUJA

L1: SPANISH

FATHERS_L1: SPANISH

MOTHERS_L2: SPANISH

LANGUAGE_AT_HOME: SPANISH

AGE_EXPOSURE: 11

SPEAKING_SELF:A2

LISTENING_SELF: A2

READING_SELF:A2

WRITING_SELF: A2

OTHER_LANGUAGE: YES

WHICH_LANG: FRENCH

ENGLISH_MARK_LAST_YEAR:6

STAY_ABROAD: NO

WHERE_STAY?:

WHEN_STAY?:

MONTHS_STAY:

EXTRAMURAL_INSTRUCTION:NO

WHEN_EXTRAMURAL:

MONTHS_EXTRAMURAL:

ADDITIONAL_EXTRAMURAL: NO

WHICH_ADDITIONAL_EXTRAMURAL:

BILINGUAL_PROGRAM: NO

WHEN_BILINGUAL_PROGRAM: 
BILINGUAL_SUBJECTS:

BILINGUAL_EXTRA_HOURS_SUBJECTS:

\section{COMPOSITION:}

One day, one \$_UNR_i dog, one boy and one frog in the vase, they was in the floor the bed. The boy was look at the frog and the bog is smell the vase. The next day for night who sleep. The frog is escape. \$_RWU_who \$_RWU_the \$_RWU_boy the next day the boy was worried and \$_RWU_is \$_RWU_going \$_RWU_to \$_INS_went look for at the frog. He went to the forest for look at the frog, he shout the name the frog. He went to the forest for look at the frog, he shout the name the frog. The boy \$_RWU_hold is hold in the one rock and branch for saw good, but one deer his was drop and he push at the river. The boy and dog was lay in the trunk. Their found at the frog the was wih your family. The boy leave at the frog with your family and up the hand \$_UNR_i and wave goodbye.

FILE_NAME: A2_2ESO_13_CAR_ADD_DSV

LEVEL: A2

INITIALS:DSV

NICK: MARÍA

AGE:13

SEX:MALE

COURSE:2 ESO

SCHOOL: CARTUJA

L1: SPANISH

FATHERS_L1: SPANISH

MOTHERS_L2: SPANISH

LANGUAGE_AT_HOME: SPANISH

AGE_EXPOSURE: 10

SPEAKING_SELF:A1

LISTENING_SELF: A1

READING_SELF:A2

WRITING_SELF: A2

OTHER_LANGUAGE: NO

WHICH_LANG:

ENGLISH_MARK_LAST_YEAR:8

STAY_ABROAD: NO

WHERE STAY?:

WHEN_STAY?:

MONTHS_STAY:

EXTRAMURAL_INSTRUCTION:NO 
WHEN_EXTRAMURAL:

MONTHS_EXTRAMURAL:

ADDITIONAL_EXTRAMURAL: NO

WHICH_ADDITIONAL_EXTRAMURAL:

BILINGUAL_PROGRAM: NO

WHEN_BILINGUAL_PROGRAM:

BILINGUAL_SUBJECTS:

BILINGUAL_EXTRA_HOURS_SUBJECTS:

COMPOSITION:

One day, a boy find a frog. He put the frog. there were a boy and dog. And a deef \$_UNR_ $\dot{c}$ at boy and fallen at water and look for and look for the frog. The boy was on the trunk \$_RWU_whas the river.

FILE_NAME: A2_2ESO_13_CAR_ADD_MCC

LEVEL: A2

INITIALS:MMC

NICK: MARIAC

AGE:13

SEX:FEMALE

COURSE:2 ESO

SCHOOL: CARTUJA

L1: SPANISH

FATHERS_L1: SPANISH

MOTHERS_L2: SPANISH

LANGUAGE_AT_HOME: SPANISH

AGE_EXPOSURE: 10

SPEAKING_SELF:A1

LISTENING_SELF: A2

READING_SELF:A1

WRITING_SELF: A2

OTHER_LANGUAGE: NO

WHICH_LANG:

ENGLISH_MARK_LAST_YEAR:5

STAY_ABROAD: NO

WHERE_STAY?:

WHEN_STAY?:

MONTHS_STAY: 
EXTRAMURAL_INSTRUCTION:NO

WHEN_EXTRAMURAL:

MONTHS_EXTRAMURAL:

ADDITIONAL_EXTRAMURAL: NO

WHICH_ADDITIONAL_EXTRAMURAL:

BILINGUAL_PROGRAM: NO

WHEN_BILINGUAL_PROGRAM:

BILINGUAL_SUBJECTS:

BILINGUAL_EXTRA_HOURS_SUBJECTS:

COMPOSITION:

One day, a boy and a dog have got a frog. They were sleeping when the frog scaped to the window. The boy and the dog \$_RWU_were \$_RWU_searched \$_RWU_to \$_RWU_they look for the house but was found. They found a forest, \$_UNR_ $\dot{\sum}$ _UNR_i The boy climb a tree, while the dog found many bee. The boy shouted worried, and the dog smelted the floor. The boy found a deer and the deer threw to river. The boy and the dog were lay on the trunk. The frog was standing with his family and the boy and the dog were looking the frogs. The boy, the dog and the frog went to house. They wave \$_UNR_i goodve to the frogs. The end.

FILE_NAME: A2_2ESO_13_CAR_ADD_CRT

LEVEL: A2

INITIALS:CRT

NICK: CRISTINX

AGE:13

SEX:FEMALE

COURSE:2 ESO

SCHOOL: CARTUJA

L1: SPANISH

FATHERS_L1: SPANISH

MOTHERS_L2: SPANISH

LANGUAGE_AT_HOME: SPANISH

AGE_EXPOSURE: 10

SPEAKING_SELF:A1

LISTENING_SELF: A1

READING_SELF:A1

WRITING_SELF: A1

OTHER_LANGUAGE: NO 
WHICH_LANG:

ENGLISH_MARK_LAST_YEAR:7

STAY_ABROAD: NO

WHERE_STAY?:

WHEN_STAY?:

MONTHS_STAY:

EXTRAMURAL_INSTRUCTION:NO

WHEN_EXTRAMURAL:

MONTHS_EXTRAMURAL:

ADDITIONAL_EXTRAMURAL: NO

WHICH_ADDITIONAL_EXTRAMURAL:

BILINGUAL_PROGRAM: NO

WHEN_BILINGUAL_PROGRAM:

BILINGUAL_SUBJECTS:

BILINGUAL_EXTRA_HOURS_SUBJECTS:

COMPOSITION:

One day, a boy find a frog. He put the frog in a vase and the boy and the dog look at it. In the night, while the boy sleep, the frog escape. Tomorrow the boy and the dog is worried on the bed. They look for the frog in a forest, in a trees, in a rock... they shout and shout. While the boy look for in the tree the dog look at bees. He shout and the dog look for under the rock too. They doesn't \$_INS_find a frog but they find a deer. It push to boy and dog and they catch to a trunk because there is one in the water. Look at under the trunk and they find a family of frogs. They hold to the frog with his hand and leave to the family and wave goodbye.

FILE_NAME: A2_2ESO_14_CAR_ADD_FCV

LEVEL: A2

INITIALS:FCV

NICK: MASHY98

AGE:14

SEX:MALE

COURSE:2 ESO

SCHOOL: CARTUJA

L1: SPANISH

FATHERS_L1: SPANISH

MOTHERS_L2: SPANISH

LANGUAGE_AT_HOME: SPANISH 
AGE_EXPOSURE: 10

SPEAKING_SELF:A1

LISTENING_SELF: A2

READING_SELF:A2

WRITING_SELF: A2

OTHER_LANGUAGE: NO

WHICH_LANG:

ENGLISH_MARK_LAST_YEAR:5

STAY_ABROAD: NO

WHERE STAY?:

WHEN_STAY?:

MONTHS_STAY:

EXTRAMURAL_INSTRUCTION:NO

WHEN_EXTRAMURAL:

MONTHS_EXTRAMURAL:

ADDITIONAL_EXTRAMURAL: NO

WHICH_ADDITIONAL_EXTRAMURAL:

BILINGUAL_PROGRAM: NO

WHEN_BILINGUAL_PROGRAM:

BILINGUAL_SUBJECTS:

BILINGUAL_EXTRA_HOURS_SUBJECTS:

COMPOSITION:

One day, \$_RWU_lav leave play my dog a frog and I look at animals. At the moment hay went a sleep a bed and my dog and my frog \$_RWU_playing escaped. I worried and my dog. I look for \$_RWU_my \$_RWU_dog and my dog. I shout in the forest and my dog. The bee atack a my dog and my look for in the forest. A the moment look for rock and hold in the branch. A continuen look for \$_UNR_i in the deer. The deer push and drop at the river, in the water look for in the trunk and find family (de) frog. The family my frog. Cat a my frog at my hand and wave goodbye the family my frog. And (me fui) at my house. A my \$_UNR_¿ house eating puchero and my dog and my frog. At the moment my vase drop and drink my water. I and my dog (nos fuismos) sleep a my bed and frog escape.

FILE_NAME: A2_2ESO_13_CAR_ADD_PAM

LEVEL: A2

INITIALS:PAM

NICK: ECKO

AGE:14 
SEX:MALE

COURSE:2 ESO

SCHOOL: CARTUJA

L1: SPANISH

FATHERS_L1: SPANISH

MOTHERS_L2: SPANISH

LANGUAGE_AT_HOME: SPANISH

AGE_EXPOSURE: 10

SPEAKING_SELF:A1

LISTENING_SELF: A1

READING_SELF:A1

WRITING_SELF: A1

OTHER_LANGUAGE: NO

WHICH_LANG:

ENGLISH_MARK_LAST_YEAR:5

STAY_ABROAD: NO

WHERE_STAY?:

WHEN_STAY?:

MONTHS_STAY:

EXTRAMURAL_INSTRUCTION:NO

WHEN_EXTRAMURAL:

MONTHS_EXTRAMURAL:

ADDITIONAL_EXTRAMURAL: NO

WHICH_ADDITIONAL_EXTRAMURAL:

BILINGUAL_PROGRAM: NO

WHEN_BILINGUAL_PROGRAM:

BILINGUAL_SUBJECTS:

BILINGUAL_EXTRA_HOURS_SUBJECTS:

COMPOSITION:

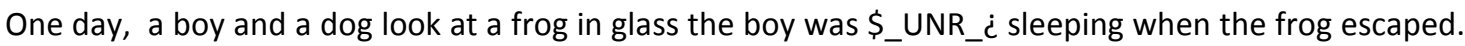
At the next morning the boy was surprised because $\$$ _UNR_i the frog was escaped. The dog \$_INS_was smelling and the boy was worried and he was shouting in the forest. The boy \$_INS_was smelling and the boy was worried and he was shouting in the forest. The boy \$_INS_was search in the trunk and the dog saw bees. And the boy \$_RWU_is \$_INS_is more worried. The dog was in the rock and he \$_INS_was holding in the branch the boy \$_INS_was find a deer and they swimming but the deer push they and fall at river. The boy didn't like water. Behind the trunk! oh! saying the boy. Were the frog family. The boy didn't was worried. The boy is fun and he wave woodbe the family. 
FILE_NAME: A2_2ESO_13_CAR_ADD_SCG

LEVEL: A2

INITIALS:SCG

NICK: REYCREEN

AGE:13

SEX:MALE

COURSE:2 ESO

SCHOOL: CARTUJA

L1: SPANISH

FATHERS_L1: SPANISH

MOTHERS_L2: SPANISH

LANGUAGE_AT_HOME: SPANISH

AGE_EXPOSURE: 10

SPEAKING_SELF:A1

LISTENING_SELF: A1

READING_SELF:A1

WRITING_SELF: A1

OTHER_LANGUAGE: NO

WHICH_LANG:

ENGLISH_MARK_LAST_YEAR:6

STAY_ABROAD: NO

WHERE_STAY?:

WHEN_STAY?:

MONTHS_STAY:

EXTRAMURAL_INSTRUCTION:NO

WHEN_EXTRAMURAL:

MONTHS_EXTRAMURAL:

ADDITIONAL_EXTRAMURAL: NO

WHICH_ADDITIONAL_EXTRAMURAL:

BILINGUAL_PROGRAM: NO

WHEN_BILINGUAL_PROGRAM:

BILINGUAL_SUBJECTS:

BILINGUAL_EXTRA_HOURS_SUBJECTS:

COMPOSITION: 
One day, there were a dog and Brey look at the frog in the bedroom. The frog escape \$_RWU_in to the bootle. While the boy \$_RWU_sleep sleept in the bed letter the boy turn up. The boy and dog find the frog in the forest. That boy be worried because don't find the frog. the boy fall the peel the boy and the dog fallen in the river in the end the boy and dog find the frog.

FILE_NAME: B2_4ESO_15_SCA_ADD_ARP

LEVEL: A2

INITIALS:JRR

NICK: JULIA

AGE:15

SEX:FEMALE

COURSE:4으을

SCHOOL: SANTA CATALINA ALEJANDRÍA

L1: SPANISH

FATHERS_L1: SPANISH

MOTHERS_L2: SPANISH

LANGUAGE_AT_HOME: SPANISH

AGE_EXPOSURE: 8

SPEAKING_SELF:A2

LISTENING_SELF: B2

READING_SELF:B1

WRITING_SELF: B1

OTHER_LANGUAGE: YES

WHICH_LANG: FRENCH

ENGLISH_MARK_LAST_YEAR:6

STAY_ABROAD: NO

WHERE_STAY?:

WHEN_STAY?:

MONTHS_STAY:

EXTRAMURAL_INSTRUCTION:NO

WHEN_EXTRAMURAL:

MONTHS_EXTRAMURAL:

ADDITIONAL_EXTRAMURAL: NO

WHICH_ADDITIONAL_EXTRAMURAL:

BILINGUAL_PROGRAM: YES

WHEN_BILINGUAL_PROGRAM: 2010

BILINGUAL_SUBJECTS: SOCIAL SCIENCES, MATHEMATICS, PHYSICS AND CHEMISTRY 
BILINGUAL_EXTRA_HOURS_SUBJECTS: AROUND 7

COMPOSITION:

One day, a boy with his dog were playing with one frog. The frog was living in a vase. when the dog was playing with the vase, the vase was opened and the frog scape it. The dog after the little boy was worried and he with his dog look for the frog. They went to a forest because he love his frog. The little boy was look for and suddenly a deer push the little boy and he fall for a clift. \$_UNR_¿ \$_RWU_a but the little boy saw a trunk and behind the trunk have a frog, his frog. The little boy took the frog and leave the forest. And they were happy.

FILE_NAME: A2_4ESO_16_SCA_ADD_EQG

LEVEL: A2

INITIALS:EQG

NICK: ELENA

AGE:16

SEX:FEMALE

COURSE:4ESO

SCHOOL: SANTA CATALINA ALEJANDRÍA

L1: SPANISH

FATHERS_L1: SPANISH

MOTHERS_L2: SPANISH

LANGUAGE_AT_HOME: SPANISH

AGE_EXPOSURE: 8

SPEAKING_SELF:B1

LISTENING_SELF: B1

READING_SELF:B1

WRITING_SELF: B1

OTHER_LANGUAGE: YES

WHICH_LANG: FRENCH

ENGLISH_MARK_LAST_YEAR:6

STAY_ABROAD: NO

WHERE_STAY?:

WHEN_STAY?:

MONTHS_STAY:

EXTRAMURAL_INSTRUCTION:NO

WHEN_EXTRAMURAL:

MONTHS_EXTRAMURAL: 


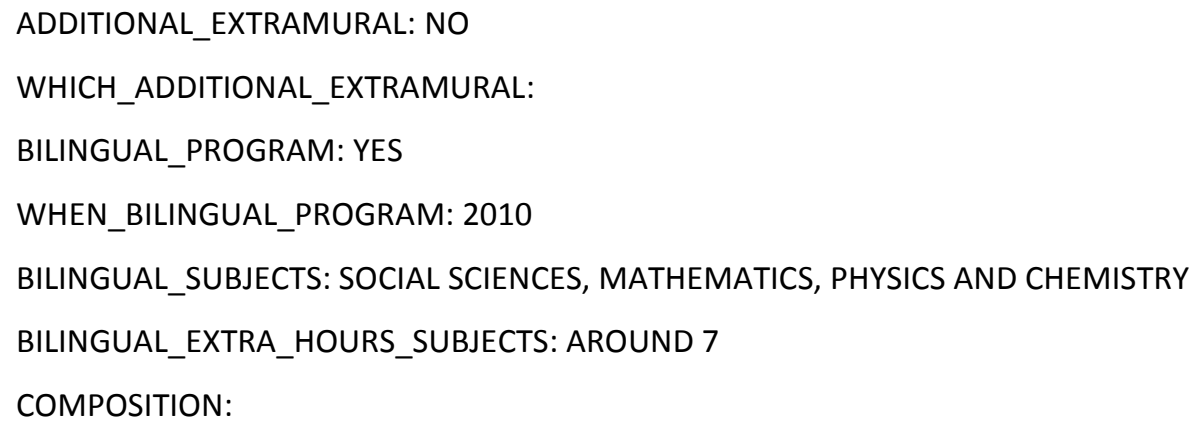

One day, I had one frog in a bottled when I go to sleep with my dog the frog was scaped and I was very worried, later I go out with my dog to look for my frog then my dog push the trunk and the bees felt,later my dog and my run and I \$_UNR_¿ fell on the deer and this hit me and I fell into the water. I was swimming and I arrived to the weith, in the weith find my frog with other frog that it is her family and finally take my frog and we leave and wave goodbye to his family. The end.

FILE_NAME: A2_4ESO_16_SCA_ADD_JAP

LEVEL: A2

INITIALS:JAP

NICK: LOSE

AGE:16

SEX:FEMALE

COURSE:4응ㅇ

SCHOOL: SANTA CATALINA ALEJANDRÍA

L1: SPANISH

FATHERS_L1: SPANISH

MOTHERS_L2: SPANISH

LANGUAGE_AT_HOME: SPANISH AND CATALAN

AGE_EXPOSURE: 5

SPEAKING_SELF:B2

LISTENING_SELF: B2

READING_SELF:B2

WRITING_SELF: B2

OTHER_LANGUAGE: YES

WHICH_LANG: FRENCH

ENGLISH_MARK_LAST_YEAR:9

STAY_ABROAD: NO

WHERE_STAY?:

WHEN_STAY?: 
MONTHS_STAY:

EXTRAMURAL_INSTRUCTION:YES

WHEN_EXTRAMURAL: SINCE 2000

MONTHS_EXTRAMURAL: 10 MONTHS PER YEAR

ADDITIONAL_EXTRAMURAL: YES

WHICH_ADDITIONAL_EXTRAMURAL: READING, WATCHING TV SHOWS

BILINGUAL_PROGRAM: YES

WHEN_BILINGUAL_PROGRAM: 2010

BILINGUAL_SUBJECTS: SOCIAL SCIENCES, MATHEMATICS, PHYSICS AND CHEMISTRY

BILINGUAL_EXTRA_HOURS_SUBJECTS: AROUND 7

COMPOSITION:

One day, I went to a lake and $i$ found a frog, then $i$ put in a vase and $i$ keep to my house. When I was sleeping the fro scape and suddenly my dog started to bark \$_UNR_i and I woke up! "Where is my frog" I said. My mother recomend me to look for it, the frog was called Gustavo. I went to the forest but I was druk and i see double... It was to dificult to walk and to listen the sound of "croc- croc" I was \$_UNR_i near a lake whe a deer hit me and I fell down in the lake. And I started to swim when I see the frog with his family! :)

FILE_NAME: A2_4ESO_16_SCA_ADD_MLV

LEVEL: A2

INITIALS:MLV

NICK: OZIL

AGE:16

SEX:MALE

COURSE:4ㅌSO

SCHOOL: SANTA CATALINA ALEJANDRÍA

L1: SPANISH

FATHERS_L1: SPANISH

MOTHERS_L2: SPANISH

LANGUAGE_AT_HOME: SPANISH AND CATALAN

AGE_EXPOSURE: 5

SPEAKING_SELF:B1

LISTENING_SELF: B2

READING_SELF:B2

WRITING_SELF: B1

OTHER_LANGUAGE: YES 


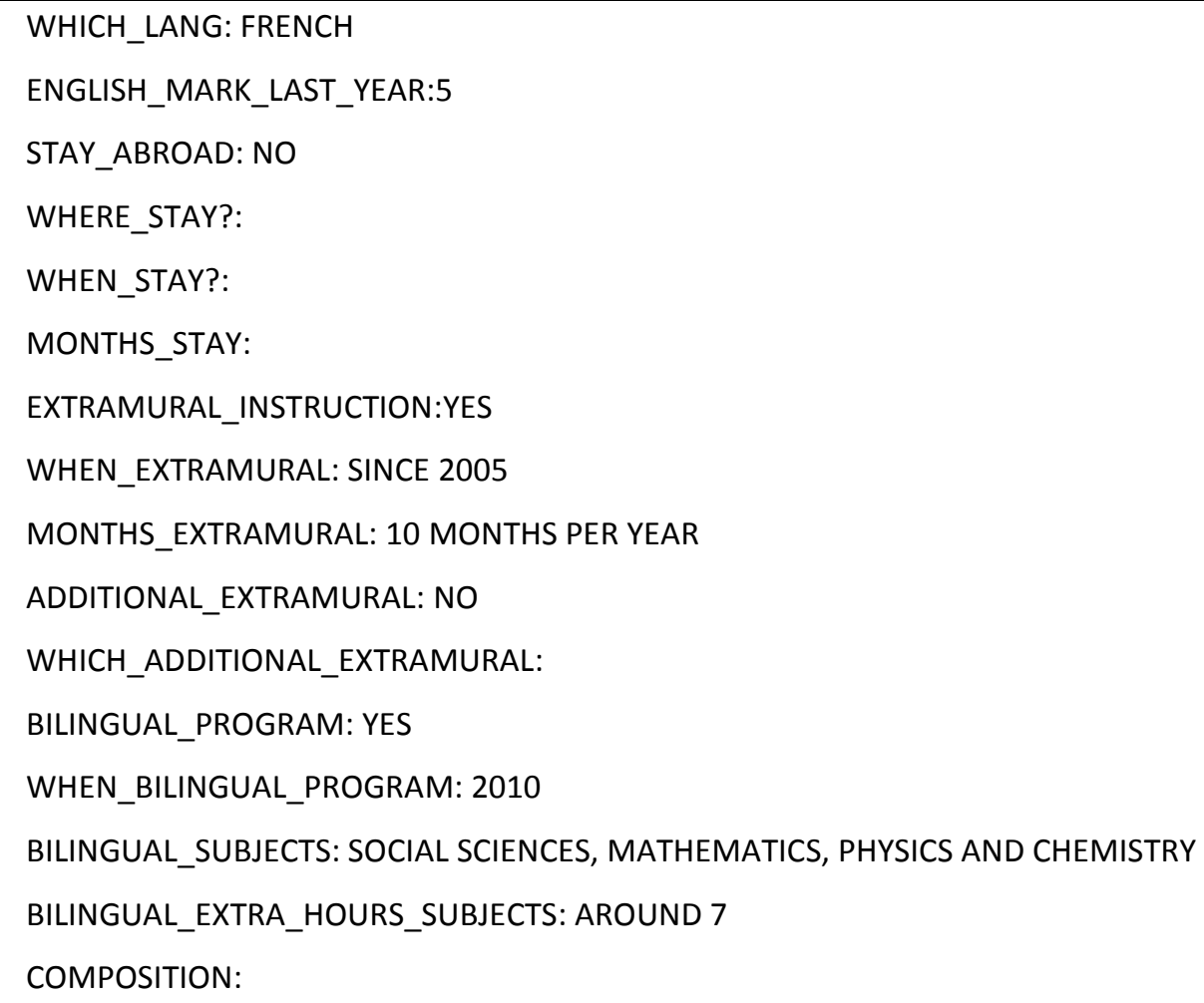

One day, my dog eat my frog, but the frog jump quickly and escape. At the next day I and my dog search my frog name's Mesut. My dog "Peri" smell and smell but don't found nothing, we searh in all of sides, on the trees, behind the rocks ... but \$_UNR_¿ when we get in to the forest and we look one deer and him go very fast to my dog and he kill \$_UNR_¿ Nesut, later the deer come at me and he push to me and I fall at \$_UNR_i the river and I open my head. \$_UNR_¿ I pass one night \$_UNR_i very bad. At the next day when I got up I see one thing, little, green ... it was my frog, with his family. I \$_UNR_¿ catch my frog and we go to the house. When we go to my house I have hunger and eat the frog. \$_UNR_¿ \$_UNR_i \$_UNR_c \$_UNR_c \$_UNR_c \$_UNR_¿ \$_UNR_c. Today I am very happy without pets.

FILE_NAME: B1_1BAC_16_SCA_ADD_AFS

LEVEL: B1

INITIALS:AFS

NICK: ÁLVARO

AGE:16

SEX:MALE

COURSE: 1ㅇACHILLER

SCHOOL: SANTA CATALINA ALEJANDRÍA

L1: SPANISH

FATHERS_L1: SPANISH

MOTHERS_L2: SPANISH 
LANGUAGE_AT_HOME: SPANISH

AGE_EXPOSURE: 6

SPEAKING_SELF:A1

LISTENING_SELF: A1

READING_SELF:A1

WRITING_SELF: A1

OTHER_LANGUAGE: YES

WHICH_LANG: FRENCH

ENGLISH_MARK_LAST_YEAR: 10

STAY_ABROAD: NO

WHERE_STAY?:

WHEN_STAY?:

MONTHS_STAY:

EXTRAMURAL_INSTRUCTION: NO

WHEN_EXTRAMURAL:

MONTHS_EXTRAMURAL:

ADDITIONAL_EXTRAMURAL:

WHICH_ADDITIONAL_EXTRAMURAL:

BILINGUAL_PROGRAM:

WHEN_BILINGUAL_PROGRAM: 2008

BILINGUAL_SUBJECTS: CMC, INTEGRATED PROJECT

BILINGUAL_EXTRA_HOURS_SUBJECTS: 4

COMPOSITION:

One day, a boy was playing with his frog and his dog. Then the frog escaped and the \$_RWU_children child shouted. After, the child went to the forest and started to looking for it. Finally, the child was pushed by a deer and he fell into the river. Fortunately, he found a trunk and he saved his lije and he left the frog inside the water

FILE_NAME: B1_1BAC_16_SCA_ADD_AFS

LEVEL: B1

INITIALS:AFS

NICK: ÁLVARO

AGE:16

SEX:MALE

COURSE: 19BACHILLER

SCHOOL: SANTA CATALINA ALEJANDRÍA

L1: SPANISH 
FATHERS_L1: SPANISH

MOTHERS_L2: SPANISH

LANGUAGE_AT_HOME: SPANISH

AGE_EXPOSURE: 12

SPEAKING_SELF:A1

LISTENING_SELF: A1

READING_SELF:A1

WRITING_SELF: A1

OTHER_LANGUAGE: YES

WHICH_LANG: FRENCH

ENGLISH_MARK_LAST_YEAR: 10

STAY_ABROAD: NO

WHERE_STAY?:

WHEN_STAY?:

MONTHS_STAY:

EXTRAMURAL_INSTRUCTION: NO

WHEN_EXTRAMURAL:

MONTHS_EXTRAMURAL:

ADDITIONAL_EXTRAMURAL:

WHICH_ADDITIONAL_EXTRAMURAL:

BILINGUAL_PROGRAM:

WHEN_BILINGUAL_PROGRAM: 2008

BILINGUAL_SUBJECTS: CMC, INTEGRATED PROJECT

BILINGUAL_EXTRA_HOURS_SUBJECTS: 4

COMPOSITION:

One day, a boy was playing with his frog and his dog. Then the frog escaped and the \$_RWU_children child shouted. After, the child went to the forest and started to looking for it. Finally, the child was pushed by a deer and he fell into the river. Fortunately, he found a trunk and he saved his lije and he left the frog inside the water

FILE_NAME: B1_1BAC_16_SCA_ADD_CSC

LEVEL: B1

INITIALS:CSC

NICK: CLARA

AGE:16

SEX:FEMALE 
COURSE: 1BACHILLER

SCHOOL: SANTA CATALINA ALEJANDRÍA

L1: SPANISH

FATHERS_L1: SPANISH

MOTHERS_L2: SPANISH

LANGUAGE_AT_HOME: SPANISH

AGE_EXPOSURE: 7

SPEAKING_SELF:A1

LISTENING_SELF: A1

READING_SELF:A1

WRITING_SELF: A1

OTHER_LANGUAGE: YES

WHICH_LANG: FRENCH

ENGLISH_MARK_LAST_YEAR: 8

STAY_ABROAD: YES

WHERE_STAY?: ENGLAND

WHEN_STAY?: 2010

MONTHS_STAY: 10 DAYS

EXTRAMURAL_INSTRUCTION: NO

WHEN_EXTRAMURAL:

MONTHS_EXTRAMURAL:

ADDITIONAL_EXTRAMURAL:

WHICH_ADDITIONAL_EXTRAMURAL:

BILINGUAL_PROGRAM:

WHEN_BILINGUAL_PROGRAM: 2008

BILINGUAL_SUBJECTS: CMC, INTEGRATED PROJECT

BILINGUAL_EXTRA_HOURS_SUBJECTS: 4

COMPOSITION:

One day, a boy with his dog had a frog. At night, when the boy and the dog where sleeping the frog escapes. The next morning they \$_RWU_i don't know where is the frog, and they go out to look for at the forest. They shout his name worried. They looked for the trees. \$_RWU_under the rocks_suddenly when the boy was on a rock appeared a deer and pushed him to the river and the boy droped in the water. He helps woth a trunk to go out the river and he \$_RWU_c find the frog's family. He leaved the frog with his family and arrived to his house. He waved good bye with the \$_RWU_i hand.

FILE_NAME: B1_1BAC_16_SCA_ADD_JPM 
LEVEL: B1

INITIALS:JPM

NICK: JORGITOPM

AGE:16

SEX:MALE

COURSE: 19BACHILLER

SCHOOL: SANTA CATALINA ALEJANDRÍA

L1: SPANISH

FATHERS_L1: SPANISH

MOTHERS_L2: SPANISH

LANGUAGE_AT_HOME: SPANISH

AGE_EXPOSURE:

SPEAKING_SELF:A1

LISTENING_SELF: A1

READING_SELF:A2

WRITING_SELF: A1

OTHER_LANGUAGE: YES

WHICH_LANG: FRENCH

ENGLISH_MARK_LAST_YEAR: 8

STAY_ABROAD: YES

WHERE_STAY?: ENGLAND

WHEN_STAY?: 2010

MONTHS_STAY: 10 DAYS

EXTRAMURAL_INSTRUCTION: NO

WHEN_EXTRAMURAL:

MONTHS_EXTRAMURAL:

ADDITIONAL_EXTRAMURAL:

WHICH_ADDITIONAL_EXTRAMURAL:

BILINGUAL_PROGRAM:

WHEN_BILINGUAL_PROGRAM: 2007

BILINGUAL_SUBJECTS: CMC, INTEGRATED PROJECT

BILINGUAL_EXTRA_HOURS_SUBJECTS: 4

COMPOSITION:

One day, a children with his dog had a frog in a bottle. At night when the boy was sleeping the frog jumped out of the bottle. The frog go out throw the window. At the next day the children was surprised because the frog had gone to the forest. The children and the dog went to look for the frog. They looked for in the river, in all the trees, and rocks. The bad thing was own a big rock there was a deer. The deer take the 
boy and the dog, and pushed them into a river. They falled near a trunk and behind him there were a frog family and in this family was his frog. The boy saw that the family was very happy and left his frog there with the family and wave goodbye and the boy and the dog arrived to them hause.

FILE_NAME: B1_1BAC_16_SCA_ADD_MDB

LEVEL: B1

INITIALS:MDB

NICK: MIGUEL

AGE:16

SEX:MALE

COURSE: 19BACHILLER

SCHOOL: SANTA CATALINA ALEJANDRÍA

L1: SPANISH

FATHERS_L1: SPANISH

MOTHERS_L2: SPANISH

LANGUAGE_AT_HOME: SPANISH

AGE_EXPOSURE: 7

SPEAKING_SELF:B2

LISTENING_SELF: B1

READING SELF:B1

WRITING_SELF: B2

OTHER_LANGUAGE: YES

WHICH_LANG: FRENCH

ENGLISH_MARK_LAST_YEAR: 7

STAY_ABROAD: YES

WHERE_STAY?: ENGLAND

WHEN_STAY?: 2010

MONTHS_STAY: 10 DAYS

EXTRAMURAL_INSTRUCTION: YES

WHEN_EXTRAMURAL: 1 MONTH PER YEAR WITH A NATIVE

MONTHS_EXTRAMURAL: 1 MONTH

ADDITIONAL_EXTRAMURAL: YES

WHICH_ADDITIONAL_EXTRAMURAL: MOVIES, READING

BILINGUAL_PROGRAM: YES

WHEN_BILINGUAL_PROGRAM: 2008

BILINGUAL_SUBJECTS: CMC, INTEGRATED PROJECT

BILINGUAL_EXTRA_HOURS_SUBJECTS: 3

COMPOSITION: 
One day, ther is a frog into a vase of glass. A boy and his dog \$_RWU_were saw this frog. When the boy and his dog go to bed, the frog escape of the vase. Next morning, when the boy got up look at the vase and start to lloking for the frog in forest. The boy shouted in all the forest. After that they climbed trees but they don't find the frog. Later, the boy and his dg go \$_RWU_into \$_RWU_a to a rock and he hold a branch, but this branch, but this branch was a deer so the deer started to run and finally stip and they fall into the river. They \$_RWU_can could see a trunk and they hold that. Finally they found the frog's family and the understood that the frog wanted to stay with his family. Then, they leave wanted to stay with his family. Then, they leave this family saying goodbye and return to house.

FILE_NAME: B1_1BAC_17_SCA_ADD_DMA

LEVEL: B1

INITIALS:DMA

NICK:Luís PEPO

AGE:17

SEX:MALE

COURSE: 19BACHILLER

SCHOOL: SANTA CATALINA ALEJANDRÍA

L1: SPANISH

FATHERS_L1: SPANISH

MOTHERS_L2: SPANISH

LANGUAGE_AT_HOME: SPANISH

AGE_EXPOSURE: 9

SPEAKING_SELF:A1

LISTENING_SELF: A1

READING_SELF:A1

WRITING_SELF: A1

OTHER_LANGUAGE: YES

WHICH_LANG: FRENCH

ENGLISH_MARK_LAST_YEAR:7

STAY_ABROAD: NO

WHERE_STAY?:

WHEN_STAY?:

MONTHS_STAY:

EXTRAMURAL_INSTRUCTION: NO

WHEN_EXTRAMURAL:

MONTHS_EXTRAMURAL: 


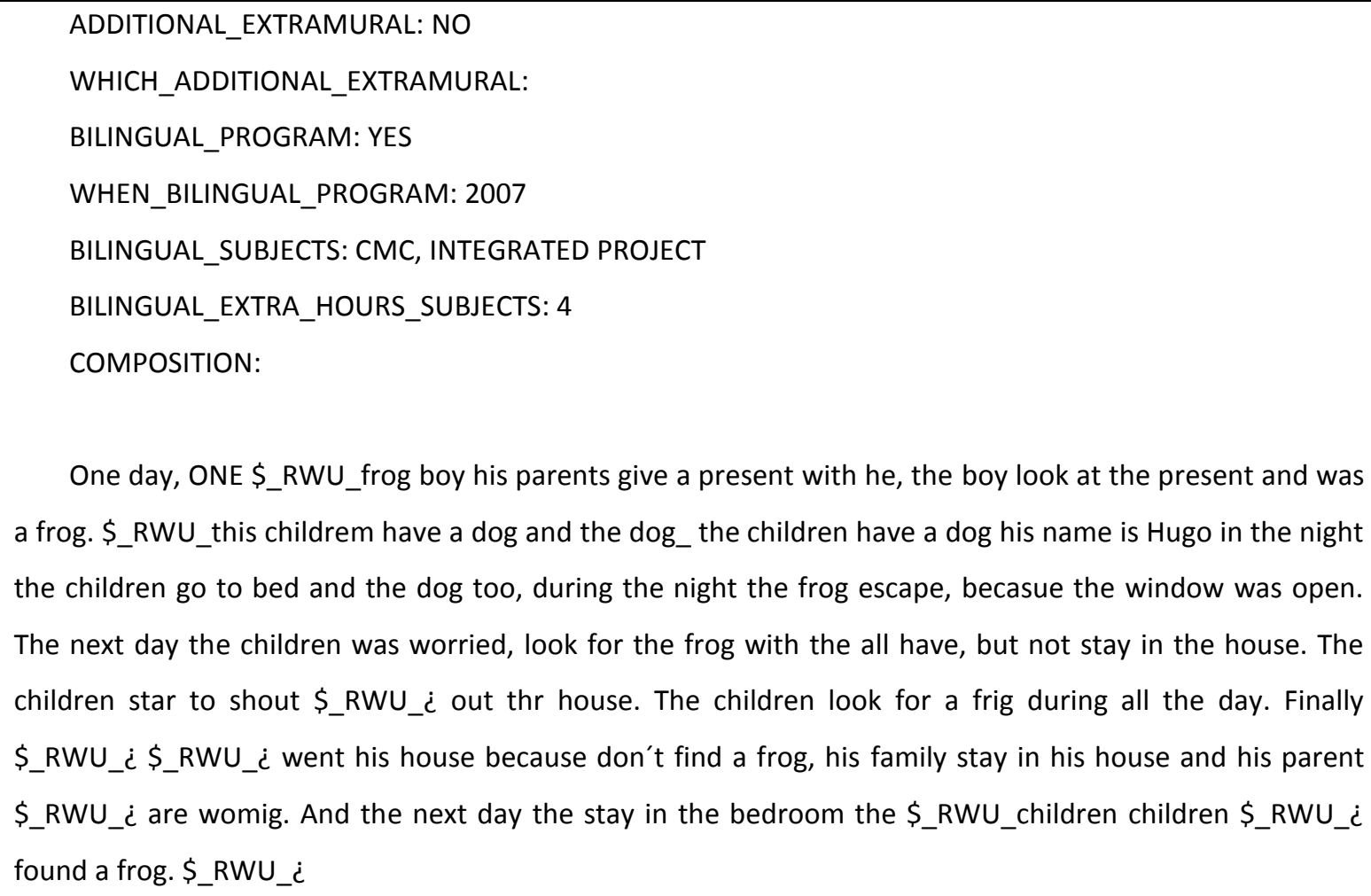

One day, ONE \$_RWU_frog boy his parents give a present with he, the boy look at the present and was a frog. \$_RWU_this childrem have a dog and the dog_the children have a dog his name is Hugo in the night the children go to bed and the dog too, during the night the frog escape, becasue the window was open. The next day the children was worried, look for the frog with the all have, but not stay in the house. The children star to shout \$_RWU_i out thr house. The children look for a frig during all the day. Finally \$_RWU_i \$_RWU_i went his house because don't find a frog, his family stay in his house and his parent \$_RWU_c are womig. And the next day the stay in the bedroom the \$_RWU_children children $\$ \_R W U_{-} i$ found a frog. \$_RWU_i

FILE_NAME: B1_1BAC_17_SCA_ADD_JGM

LEVEL: B1

INITIALS:JGM

NICK:Luís GABI

AGE:17

SEX:MALE

COURSE: 19BACHILLER

SCHOOL: SANTA CATALINA ALEJANDRÍA

L1: SPANISH

FATHERS_L1: SPANISH

MOTHERS_L2: SPANISH

LANGUAGE_AT_HOME: SPANISH

AGE_EXPOSURE: 9

SPEAKING_SELF:B1

LISTENING_SELF: B1

READING_SELF:B1

WRITING_SELF: B1

OTHER_LANGUAGE: YES

WHICH_LANG: FRENCH

ENGLISH_MARK_LAST_YEAR:9 
STAY_ABROAD: YES

WHERE_STAY?: ENGLAND

WHEN_STAY?: 2011

MONTHS_STAY: 10 DAYS

EXTRAMURAL_INSTRUCTION: NO

WHEN_EXTRAMURAL:

MONTHS_EXTRAMURAL:

ADDITIONAL_EXTRAMURAL: YES

WHICH_ADDITIONAL_EXTRAMURAL: PLAYING ENGLISH MUSIC

BILINGUAL_PROGRAM: YES

WHEN_BILINGUAL_PROGRAM: 2007

BILINGUAL_SUBJECTS: CMC, INTEGRATED PROJECT

BILINGUAL_EXTRA_HOURS_SUBJECTS: 4

COMPOSITION:

One day, the little \$_RWU_pedro \$_INS_peter hunted a frog. \$_RWU_that \$_RWU_night \$_RWU_his \$_RWU_dog \$_RWU_called \$_RWU_Toby \$_RWU_and \$_RWU_him That night the frog were put on a vase by \$_RWU_pedro \$_INS_peter and his super-intelligent dog, that can speak three languages, \$_RWU_calle Toby. While they were sleeping the frog escaped to the forest because he want to find his family. The next morning Peter woke up early because he wanted to play with him and his dog. But when he found the vase without the frog he started to cry. The dog said him.- \$_RWU_don't \$_RWU_worry Do not worry Peter, i \$_RWU_thik think he can't be very for.- I am agree with you Toby-, said Peter.- Where \$_RWU_should we should be start to looking for him?.- In \$_RWU_side the forest! Both friends started to walk along the little forest but it started to be clark and the return to home.

FILE_NAME: B1_1BAC_17_SCA_ADD_MPS

LEVEL: B1

INITIALS:MPS

NICK: MARTA

AGE:17

SEX:FEMALE

COURSE: 19BACHILLER

SCHOOL: SANTA CATALINA ALEJANDRÍA

L1: SPANISH

FATHERS_L1: SPANISH

MOTHERS_L2: SPANISH

LANGUAGE_AT_HOME: SPANISH 


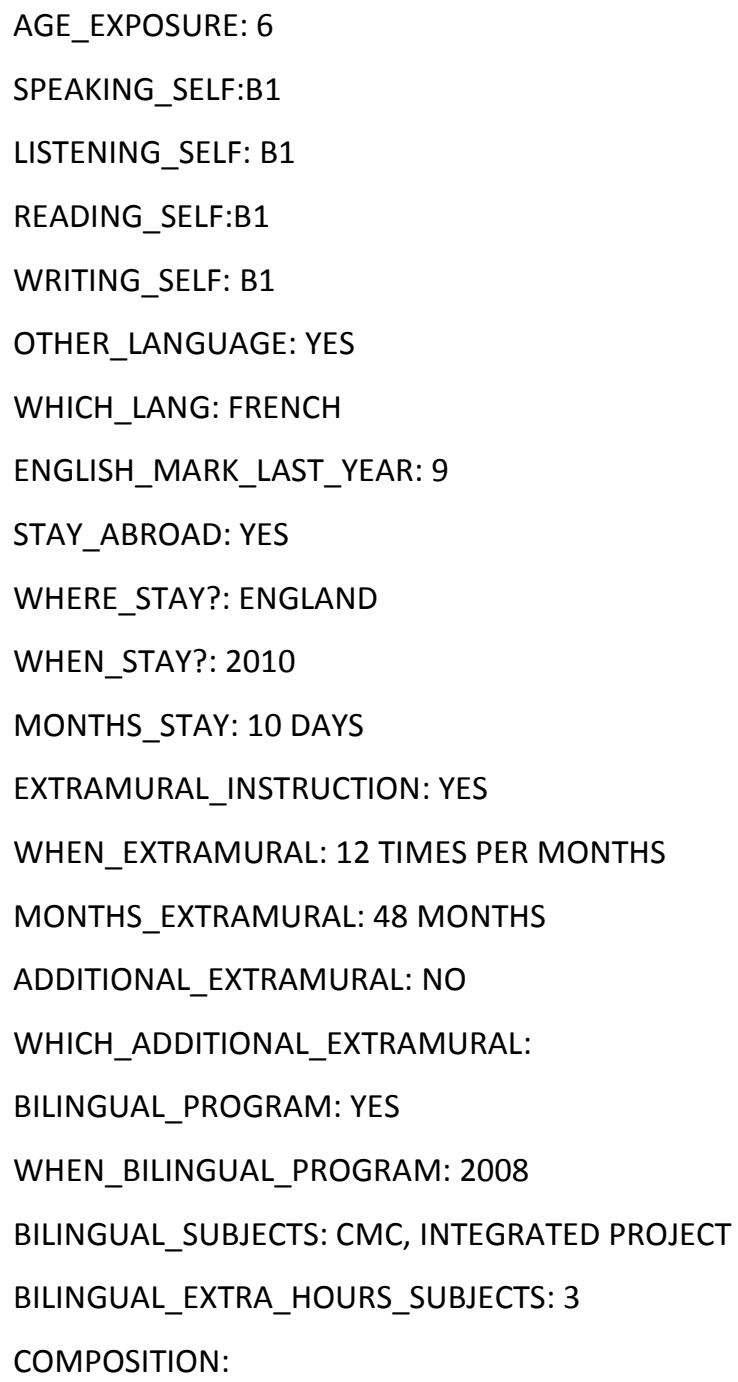

One day, a boy had a frog in a vase. In the night, while the boy was sleeping, the frog scaped from the vase. In the next morning when he put the frog the day before and the by S_RWU_were was worried. Then, the boy \$_RWU_was went to the forest \$_Ins_with the dog to look for his frog, and he started to shout to call the frog. He was worried and climbed a tree to llok for the frog and he climbed a rock too, but he didn't find the frog. Suddenly, a deer pushed the boy and he fall to the river and he couldn't swim, but the dog rescated him and took him to a trunk. In the trunk there was a family of frogs, and here was the boy's frog \$_RWU_so he catched the frog. One hour later, the boy catched the frog said goodbye to the family and returned to his house.

FILE_NAME: B1_1BAC_17_SCA_ADD_PRM

LEVEL: B1

INITIALS:PRM

NICK: Paula

AGE:17 
SEX:FEMALE

COURSE: 1BACHILLER

SCHOOL: SANTA CATALINA ALEJANDRÍA

L1: SPANISH

FATHERS_L1: SPANISH

MOTHERS_L2: SPANISH

LANGUAGE_AT_HOME: SPANISH

AGE_EXPOSURE: 7

SPEAKING_SELF:B1

LISTENING_SELF: B1

READING_SELF:B1

WRITING_SELF: A2

OTHER_LANGUAGE: YES

WHICH_LANG: FRENCH

ENGLISH_MARK_LAST_YEAR: 9

STAY_ABROAD: YES

WHERE_STAY?: ENGLAND

WHEN_STAY?: 2010

MONTHS_STAY: 10 DAYS

EXTRAMURAL_INSTRUCTION: NO

WHEN_EXTRAMURAL:

MONTHS_EXTRAMURAL:

ADDITIONAL_EXTRAMURAL: NO

WHICH_ADDITIONAL_EXTRAMURAL:

BILINGUAL_PROGRAM: YES

WHEN_BILINGUAL_PROGRAM: 2008

BILINGUAL_SUBJECTS: CMC, INTEGRATED PROJECT

BILINGUAL_EXTRA_HOURS_SUBJECTS: 3

COMPOSITION:

One day, a boy was boring looking his frog that this morning had found in the lake, later his mum said him that it was late and he had to go to the bed. Whlie he was sleep, the frog \$_RWU_i, wich was so intelligent, scaped of the vase. In the morning woke up quickly to see the frog but it wasn't there, worried he said to \$_RWU_i his mum that he had to look for the frog because it might be in danger. He went with his dog to the lake where he found it and shouted and shouted but it hadn't result. He looked inside of a tree, in the wood bot nothing there wasn't nothing. Suddenly he heard a noisy behing of him, it was a deer

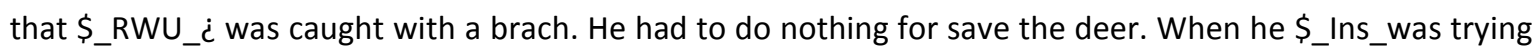
to help it he fall down to the $\$$ RWU_river lake but he was so lucky because there was a branch in the lake 
and he could scape. \$_RWU_Finally he found and tried to go to his house again, but he didn't remember the wall. Finally his parents were looking for him and found him next to the lake.

FILE_NAME: B1_2BAC_17_CAR_ADD_IMR

LEVEL: B1

INITIALS:IMR

NICK: PUMA

AGE:17

SEX:FEMALE

COURSE:2 ESO

SCHOOL: CARTUJA

L1: SPANISH

FATHERS_L1: SPANISH

MOTHERS_L2: SPANISH

LANGUAGE_AT_HOME: SPANISH

AGE_EXPOSURE: 6

SPEAKING_SELF:A2

LISTENING_SELF: A1

READING_SELF:B1

WRITING_SELF: A2

OTHER_LANGUAGE: YES

WHICH_LANG: FRENCH

ENGLISH_MARK_LAST_YEAR:6

STAY_ABROAD: NO

WHERE_STAY?:

WHEN_STAY?:

MONTHS_STAY:

EXTRAMURAL_INSTRUCTION:NO

WHEN_EXTRAMURAL:

MONTHS_EXTRAMURAL:

ADDITIONAL_EXTRAMURAL: NO

WHICH_ADDITIONAL_EXTRAMURAL:

BILINGUAL_PROGRAM: NO

WHEN_BILINGUAL_PROGRAM:

BILINGUAL_SUBJECTS:

BILINGUAL_EXTRA_HOURS_SUBJECTS:

COMPOSITION: 
One day, a little boy was very happy because his mother give it for his birthday a big frog. One day while the boy was sleepong the frog escaped to the forest. In the morning when the boy got up and saw that the frog wasn't there he worried for it, and he started to look for in the forest, in the mountain, in the tree, in the trunk, he shout very much but the big frog wasn't in nothing hand. A bee left of a trunk and the boy have afraid of \$_RWU_bee it. He \$_UNR_¿ in a rock and shout very strong. He was look in a rock when a deer appear and he felt the mountain since a river when he fell in a branch. His clothes had \$_UNR_¿ the boy found the frog and they went with the frog saying goodbye to the others frog.

FILE_NAME: B1_2BAC_18_CAR_ADD_JCC

LEVEL: B2

INITIALS:JCC

NICK: KILY959

AGE:17

SEX:MALE

COURSE: 2BAC

SCHOOL: CARTUJA

L1: SPANISH

FATHERS_L1: SPANISH

MOTHERS_L2: SPANISH

LANGUAGE_AT_HOME: SPANISH

AGE_EXPOSURE: 5

SPEAKING_SELF:B1

LISTENING_SELF: B2

READING_SELF:B1

WRITING_SELF: B1

OTHER_LANGUAGE: YES

WHICH_LANG: FRENCH

ENGLISH_MARK_LAST_YEAR:7

STAY_ABROAD: NO

WHERE_STAY?:

WHEN_STAY?:

MONTHS_STAY: 10 DAYS

EXTRAMURAL_INSTRUCTION: NO

WHEN_EXTRAMURAL:

MONTHS_EXTRAMURAL:

ADDITIONAL_EXTRAMURAL: NO

WHICH_ADDITIONAL_EXTRAMURAL: 


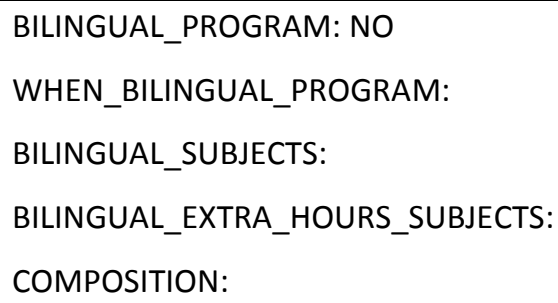

One day, \$_RWU_while \$_RWU_stayed was stayed in my bedroom looking at my frog with my dog, shoggy. When I was sleeping my frog scaped of his vase and she went out away. Three hours later, my dog awoke and he saw the situation. A few minutes later, I arose and my frog didn't stay there. I was very sad and worried. My dog started to smell and he didn't found her. I decided to go out at the forest, because I thought the the frog would stay there. I started to shout, but the frog didn't appear. When I saw a tree, I \$_RWU_will jumped and I found a lot of bees. Later, I jumped in a rock and shouted again. Suddenly, a deer pushed me and I fell to the river, with my dog. I held a trnuk and finally, I found my frog. I was really happy. My frog was a family. Finally my frog jumped at my hand and we wave goodbye at her family.

FILE_NAME: B2_2BAC_18_CAR_ADD_MAK

LEVEL: B2

INITIALS:MAK

NICK: MAR

AGE:18

SEX:FEMALE

COURSE:2 ESO

SCHOOL: CARTUJA

L1: SPANISH

FATHERS_L1: ARABIC

MOTHERS_L2: ARABIC

LANGUAGE_AT_HOME: ARABIC

AGE_EXPOSURE: 6

SPEAKING_SELF:A1

LISTENING_SELF: A1

READING_SELF:A1

WRITING_SELF: A1

OTHER_LANGUAGE: YES

WHICH_LANG: FRENCH, ARABIC

ENGLISH_MARK_LAST_YEAR:6

STAY_ABROAD: NO

WHERE_STAY?: 
WHEN_STAY?:

MONTHS_STAY:

EXTRAMURAL_INSTRUCTION:NO

WHEN_EXTRAMURAL:

MONTHS_EXTRAMURAL:

ADDITIONAL_EXTRAMURAL: NO

WHICH_ADDITIONAL_EXTRAMURAL:

BILINGUAL_PROGRAM: NO

WHEN_BILINGUAL_PROGRAM:

BILINGUAL_SUBJECTS:

BILINGUAL_EXTRA_HOURS_SUBJECTS:

COMPOSITION:

One day, a dog, and \$_UNR_i a boy was setting in the room looking at the frog, wheen the dog and the boy went to sleep in the bed, they left the frog in the floor inside a vase, \$_UNR_ $\dot{\Sigma}$ it was night and the frog escaped, when the boy stood at the morning, he didn't found it, as he was worried he \$_RWU_go \$_INS_went out to look for it. he was founding in the forest and he was shouting when the dog smelt a smal and the started runing. \$_RWU_the small was the small of the bees they continued finding the boy in a rock

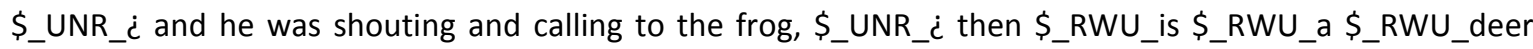
\$_RWU_who \$_RWU_he \$_RWU_was \$_RWU_in \$_RWU_the when the boy was holding a branch a deer appeared and he catch the boy and pushed it, the boy \$_UNR_i droped at the river, he and his dog. \$_RWU_tha \$_RWU_he \$_UNR_i \$_UNR_c \$_UNR_c \$_RWU_at \$_RWU_the \$_RWU_water when they \$_RWU_dop droped at the water, they found a $\$ \_R W U_{-}$trunch trunk of a tree, and on front of the trunk, there are a family of frogs, \$_RWU_wh with there are the boy's frog, \$_UNR_i \$_UNR_i $\$ \_U N R \_i$ \$_UNR_ $\dot{\$}$ \$UNR_i $\$ \_U N R \_i$ the frogs was given to the boy, and finally, they went with the frogs $\$ \_U N R \_i$ and they wave goodbye to the family frog.

FILE_NAME: B1_2BAC_18_CAR_ADD_RGM

LEVEL: B1

INITIALS:RGM

NICK: MY FROG

AGE:19

SEX:MALE

COURSE: 2BAC

SCHOOL: CARTUJA

L1: SPANISH

FATHERS_L1: SPANISH 


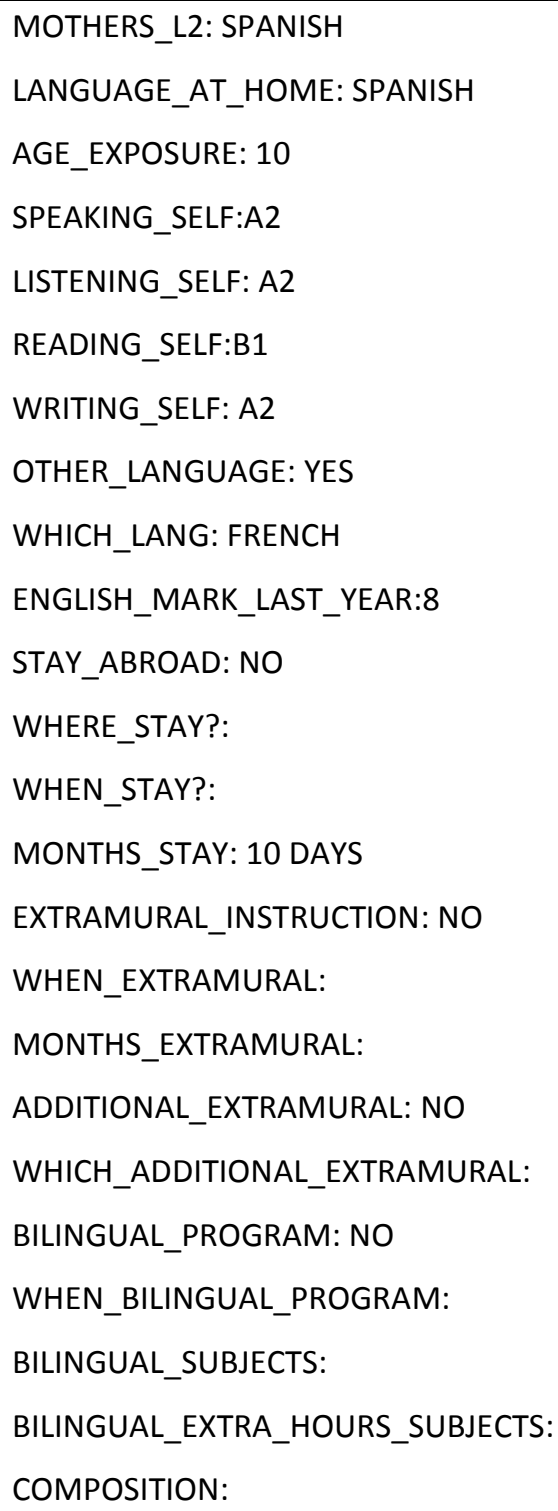

One day, the boy and his dog were looking to the frog that they have catched before. they left the frog in a vase and the boy with his dog went to sleep. During the night, thet frog escaped and went out of the vase. Next day, the boy was worried about what will happened to the frogs and he decided to look for his frog with his dog. He shouted looking for the frog and they went into the forest. There, the boy climbed a tree for looking into a hole, and the dog was near of a lot of bees. The boy climbed a rock and hold a large brach to shouted again for looking the frog then, the branch moved, and became into a deer. The deer, furiously, \$_UNR_¿ pushed the boy and he dropped in a river. The boy took a trunk, and there he found the frog's family. Then the boy decided to left the frog with his family, and with his hand he said goodbye.

FILE_NAME: B1_4ESO_15_SCA_ADD_MDG

LEVEL: B1

INITIALS:MDG 
NICK: MARÍA

AGE:15

SEX:FEMALE

COURSE: 4ESO

SCHOOL: SANTA CATALINA ALEJANDRÍA

L1: SPANISH

FATHERS_L1: SPANISH

MOTHERS_L2: SPANISH

LANGUAGE_AT_HOME: SPANISH

AGE_EXPOSURE: 8

SPEAKING_SELF:B1

LISTENING_SELF: B1

READING SELF:B1

WRITING_SELF: B1

OTHER_LANGUAGE: YES

WHICH_LANG: FRENCH

ENGLISH_MARK_LAST_YEAR:7

STAY_ABROAD: NO

WHERE_STAY?:

WHEN_STAY?:

MONTHS_STAY: 10

EXTRAMURAL_INSTRUCTION: NO

WHEN_EXTRAMURAL:

MONTHS_EXTRAMURAL:

ADDITIONAL_EXTRAMURAL: YES

WHICH_ADDITIONAL_EXTRAMURAL:

BILINGUAL_PROGRAM: YES

WHEN_BILINGUAL_PROGRAM: 2008

BILINGUAL_SUBJECTS: SOCIAL SCIENCES, MATHEMATICS, PHYSICS AND CHEMISTRY

BILINGUAL_EXTRA_HOURS_SUBJECTS: AROUND 7

COMPOSITION:

One day, a boy was in his bedroom with his dog and with a vase with a forg. He went to bed when he was sleep, the frog escapes. At the morning, the frog wasn't there and the boy was worried. He and his dog looking for him in the forest. They shouted, but the frog \$_UNR_i didn't appeare. The boy was on a rock and he hold a branch, but it wasn't a branch, it was a deer. The deer pushed him and he droped into the river and his dog too. The dog help him and they caugh exit to the river. Suddenly behind a trunk \$_UNR_i 
was \$_UNR_i the frog with \$_RWU_him \$_INS_his family and the boy leave their and \$_RWU_go wave goodbue.

FILE_NAME: B1_4ESO_15_SCA_ADD_MMQ

LEVEL: B1

INITIALS:MMQ

NICK: MIGUELILLO

AGE:15

SEX:MALE

COURSE: 4ESO

SCHOOL: SANTA CATALINA ALEJANDRÍA

L1: SPANISH

FATHERS_L1: SPANISH

MOTHERS_L2: SPANISH

LANGUAGE_AT_HOME: SPANISH

AGE_EXPOSURE: 8

SPEAKING_SELF:B1

LISTENING_SELF: B1

READING_SELF:B1

WRITING_SELF: B1

OTHER_LANGUAGE: YES

WHICH_LANG: FRENCH

ENGLISH_MARK_LAST_YEAR:10

STAY_ABROAD: NO

WHERE_STAY?:

WHEN_STAY?:

MONTHS_STAY:

EXTRAMURAL_INSTRUCTION: YES

WHEN_EXTRAMURAL: SINCE 2004

MONTHS_EXTRAMURAL: 8 PER YEAR

ADDITIONAL_EXTRAMURAL: YES

WHICH_ADDITIONAL_EXTRAMURAL:READING SOME ARTICLES, WATCHING MOVIES, LISTENING TO MUSIC

BILINGUAL_PROGRAM: YES

WHEN_BILINGUAL_PROGRAM: 2007

BILINGUAL_SUBJECTS: SOCIAL SCIENCES, MATHEMATICS, PHYSICS AND CHEMISTRY

BILINGUAL_EXTRA_HOURS_SUBJECTS: AROUND 7 


\section{COMPOSITION:}

One day, a boy bought a frog. He and his dog were very interested in \$_RWU_the \$_RWU_frog. He put \$_RWU_the \$_RWU_frog \$_INS_it into a vase and he and his dog spent the all day watching the frog. While he was sleeping the frog \$_UNR_¿ \$_UNR_i climbed the vase and it went away. In the morning the boy noticed that the frog wasn't in the vase. The boy and his dog went out to look for his \$_UNR_i frog. He went to a forest and he looked into a tree \$_INS_and he climbed a rock but in that rock there was a deer. The deer threw \$_INS_away the boy and his dog. They landed into a river they swam from the river to the shole of the river and he sat on a trunk. While he was laying he saw his frog with other frogs, so he took his frog and they \$_RWU_waved \$_RWU_away \$_INS_said \$_INS_goodbye to the other frogs.

FILE_NAME: B1_4ESO_15_SCA_ADD_PMP

LEVEL: B1

INITIALS:PMP

NICK: JOSE MARÍA CALLEJÓN

AGE:15

SEX:MALE

COURSE: 4ESO

SCHOOL: SANTA CATALINA ALEJANDRÍA

L1: SPANISH

FATHERS_L1: SPANISH

MOTHERS_L2: SPANISH

LANGUAGE_AT_HOME: SPANISH

AGE_EXPOSURE: 6

SPEAKING_SELF:B1

LISTENING_SELF: A2

READING_SELF:B1

WRITING_SELF: B1

OTHER_LANGUAGE: YES

WHICH_LANG: FRENCH

ENGLISH_MARK_LAST_YEAR:6

STAY_ABROAD: NO

WHERE_STAY?:

WHEN_STAY?:

MONTHS_STAY:

EXTRAMURAL_INSTRUCTION: NO

WHEN_EXTRAMURAL: 
MONTHS_EXTRAMURAL:

ADDITIONAL_EXTRAMURAL:

WHICH_ADDITIONAL_EXTRAMURAL:

BILINGUAL_PROGRAM: YES

WHEN_BILINGUAL_PROGRAM: 2007

BILINGUAL_SUBJECTS: SOCIAL SCIENCES, MATHEMATICS, PHYSICS AND CHEMISTRY

BILINGUAL_EXTRA_HOURS_SUBJECTS: AROUND 7

COMPOSITION:

One day, my frog escape of my house. In this moment we was thinking that our frog was lost. We looked for in all the house, but we didn't found she. I was worried, becasue I had a lot of love for this frog, and I was to sad. About my family, they didn't mind lost this alimal, because they didn't feel the same that

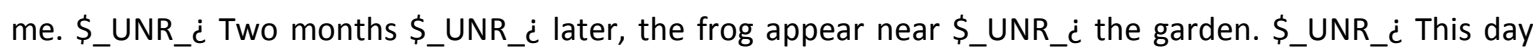
was to special for me. Now we look after she a lot

FILE_NAME: B1_4ESO_15_SCA_ADD_RLM

LEVEL: B1

INITIALS:RLM

NICK: RAQUEL

AGE:15

SEX:MALE

COURSE: 4ESO

SCHOOL: SANTA CATALINA ALEJANDRÍA

L1: SPANISH

FATHERS_L1: SPANISH

MOTHERS_L2: SPANISH

LANGUAGE_AT_HOME: SPANISH

AGE_EXPOSURE: 8

SPEAKING_SELF:B1

LISTENING_SELF: A2

READING_SELF:B1

WRITING_SELF: B1

OTHER_LANGUAGE: YES

WHICH_LANG: FRENCH

ENGLISH_MARK_LAST_YEAR:10

STAY_ABROAD: NO

WHERE_STAY?: 
WHEN_STAY?:

MONTHS_STAY:

EXTRAMURAL_INSTRUCTION: YES

WHEN_EXTRAMURAL: 2007

MONTHS_EXTRAMURAL:

ADDITIONAL_EXTRAMURAL: YES

WHICH_ADDITIONAL_EXTRAMURAL: WATCHING TV SHOWS AND LISTENING TO MUSIC

BILINGUAL_PROGRAM: YES

WHEN_BILINGUAL_PROGRAM: 2007

BILINGUAL_SUBJECTS: SOCIAL SCIENCES, MATHEMATICS, PHYSICS AND CHEMISTRY

BILINGUAL_EXTRA_HOURS_SUBJECTS: AROUND 7

COMPOSITION:

One day, a boy found a frog in the river, he decided to cought the frog and took it to his house. When he was in his house he put the frog into a bottle made by glass. He stayed all the evening looked at the frog but out 11 o'clock he was tired and he went to bed. At midnight the frog wake up and \$_UNR_i it escaped from the room. When the boy wake up \$_RWU_at the next day the frog wasn't there. He was worried about his mother because she doesn't like frogs. He decided to went out with his dog to looked for the frog. They looked in \$_UNR_i a very big tree, behind the rocks and between the grass but they didn't see anything. He saw a big animal, \$_RWU_and it was a deer. The deer pushed him into the water. Finally when he was going out from the water he saw some frongs where it was his frog. He \$_UNR_i caught it and they returned to his house.

LEVEL: B1

INITIALS:SAC

NICK: SOFI

AGE:15

SEX:FEMALE

COURSE: 4ESO

SCHOOL: SANTA CATALINA ALEJANDRÍA

L1: SPANISH

FATHERS_L1: SPANISH

MOTHERS_L2: SPANISH

LANGUAGE_AT_HOME: SPANISH

AGE_EXPOSURE: 8

SPEAKING_SELF:B1

LISTENING_SELF: B1 


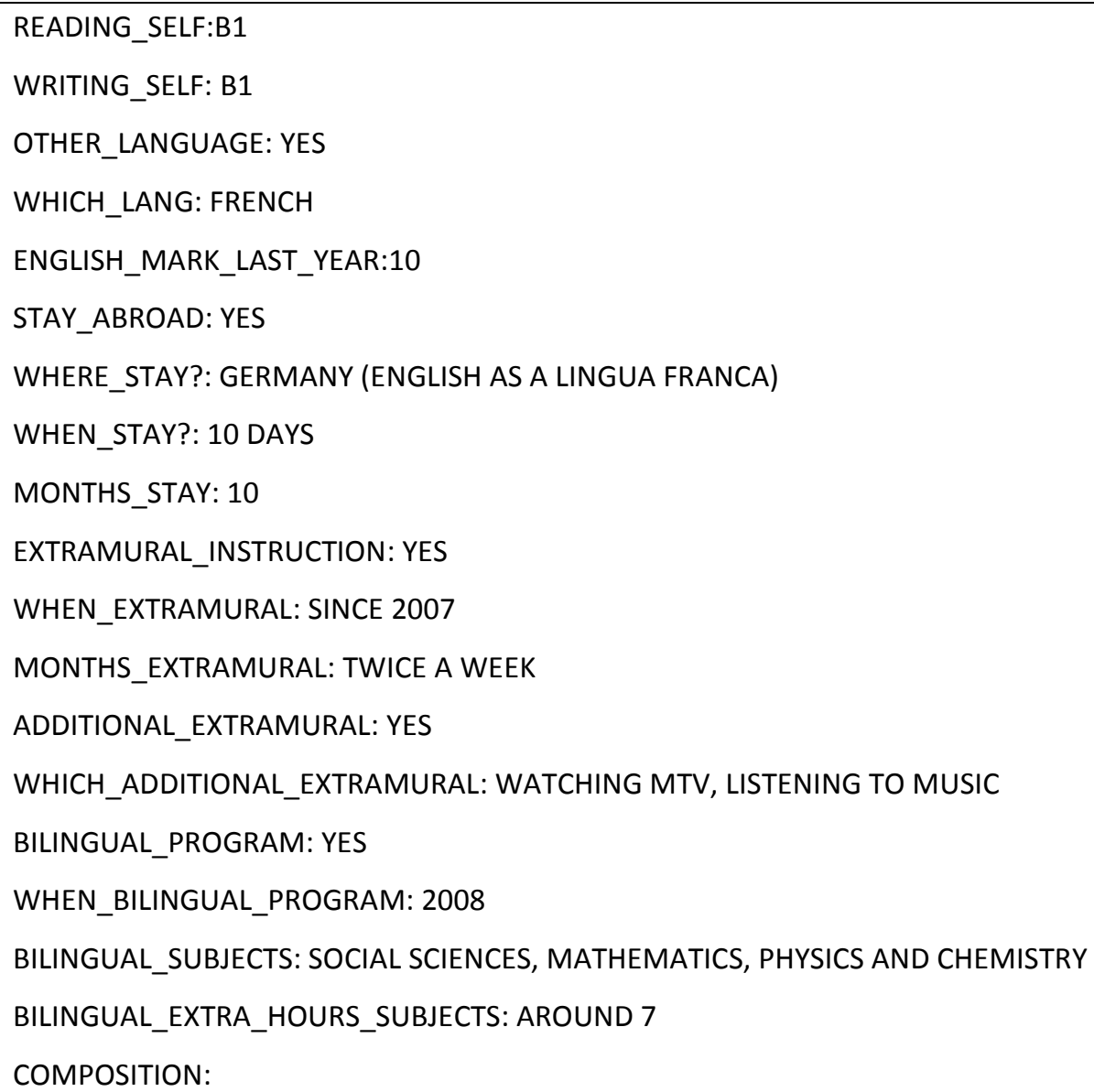

One day, a boy called Nick caught a little \$_UNR_¿ frog form the river near his house. He put in into a glass bottle. He felt very happy because he has always wanted to have a frog! At night Nick and his dog Sammy went to sleep. Next day they woke up and Nick was very surprised: the frog wasn't in the bottle. Nick started to be a little nervous. First he asked to his mother, next to his father and later to his sister. Nobody knew where was the frog. One hour later he decided to go to the country near his house. Sammy went with him. Nick look for the frog in many places: between the trees, between the rocks, behind the mountains, under the flowers... Even Sammy look for it in the trees! In the afternoon the frog was still disapeared and Nick started to be so worried. Behind a tree, Sammy heared something \$_UNR_¿ straight sound. Nick went there and it was a deer! It pushed him and Nick fell down to the river. But later, Sammy heared another sound behind a trunk... the frog was there! Nick caught again the frog and Sammy and him came back to Nick's house.

FILE_NAME: B1_4ESO_15_SCA_ADD_TFL

LEVEL: B1

INITIALS:TFL

NICK: TERESITA

AGE:15 
SEX:FEMALE

COURSE: 4ESO

SCHOOL: SANTA CATALINA ALEJANDRÍA

L1: SPANISH

FATHERS_L1: SPANISH

MOTHERS_L2: SPANISH

LANGUAGE_AT_HOME: SPANISH

AGE_EXPOSURE: 6

SPEAKING_SELF:B2

LISTENING_SELF: B2

READING_SELF:B2

WRITING_SELF: B2

OTHER_LANGUAGE: YES

WHICH_LANG: FRENCH

ENGLISH_MARK_LAST_YEAR:9

STAY_ABROAD: YES

WHERE_STAY?: ENGLAND

WHEN_STAY?: 2005, 2010

MONTHS_STAY: 2 MONTHS

EXTRAMURAL_INSTRUCTION: YES

WHEN_EXTRAMURAL: SINCE 2002

MONTHS_EXTRAMURAL: 8 PER YEAR

ADDITIONAL_EXTRAMURAL: YES

WHICH_ADDITIONAL_EXTRAMURAL:READING SOME ARTICLES, WATCHING MOVIES, LISTENING TO MUSIC

BILINGUAL_PROGRAM: YES

WHEN_BILINGUAL_PROGRAM: 2007

BILINGUAL_SUBJECTS: SOCIAL SCIENCES, MATHEMATICS, HISTORY

BILINGUAL_EXTRA_HOURS_SUBJECTS: AROUND 7

COMPOSITION:

One day, John was \$_RWU_wat looking at his new frog. His parents had given it as a present for his birthday. John loved animals, he also have a dog. When time to sleep arrived, he decided to put the frog inside one glass vase. He do it and he go to bed. When John woke up, he could \$_RWU_¿ see that the frog was disappeared. He cried, and cried. He called it again and again, but the frog was still disappeared. "Where could froggy be?" Asked \$_INS_John to himself \$_RWU_John. He went to the forest with her dog, but he didn't find anything when John was climbing \$_RWU_the one rock, suddenly, a deer appeared from the branches, and it trew away John and his dog. They dropped in a river, and they could safe themself with 
the help of a trunk. Afortunately, behind the trunk was the frog! It was with its family but John take it and \$_UNR_¿ came back to home \$_RWU_happ terrorificly happy.

FILE_NAME: B1_4ESO_16_SCA_ADD_ALS

LEVEL: B1

INITIALS:ALS

NICK: COOKIE MONSTA

AGE:16

SEX:MALE

COURSE: 4ESO

SCHOOL: SANTA CATALINA ALEJANDRÍA

L1: SPANISH

FATHERS_L1: SPANISH

MOTHERS_L2: SPANISH

LANGUAGE_AT_HOME: SPANISH

AGE_EXPOSURE: 4

SPEAKING_SELF:B2

LISTENING_SELF: B2

READING_SELF:B2

WRITING_SELF: B2

OTHER_LANGUAGE: YES

WHICH_LANG: FRENCH

ENGLISH_MARK_LAST_YEAR:8

STAY_ABROAD: NO

WHERE_STAY?:

WHEN_STAY?:

MONTHS_STAY:

EXTRAMURAL_INSTRUCTION: YES

WHEN_EXTRAMURAL: 2001

MONTHS EXTRAMURAL: 9 PER YEAR

ADDITIONAL_EXTRAMURAL: NO

WHICH_ADDITIONAL_EXTRAMURAL:

BILINGUAL_PROGRAM: YES

WHEN_BILINGUAL_PROGRAM: 2008

BILINGUAL_SUBJECTS: SOCIAL SCIENCES, MATHEMATICS, PHYSICS AND CHEMISTRY

BILINGUAL_EXTRA_HOURS_SUBJECTS: AROUND 7

COMPOSITION: 
One day, when I were going to sleep, I spent some time \$_RWU_watching looking at Pickachu, my small frog. Then I went to bed and suddenly when I got up I saw that my frog has gone and I went to the country side to look for it. I went into the forest and looked in some trunks but I couldn't find my frog. Then \$_RWU_I \$_RWU_found \$_RWU_some \$_RWU_mushrooms \$_RWU_and I climbed a rock and started to shout. Suddenly a deer got up and throw me into the swam. And I found my frog! It was with it family. Fortunately we came back home at dinner time. THE END.

FILE_NAME: B1_4ESO_16_SCA_ADD_AUG

LEVEL: B1

INITIALS:AUG

NICK: UCE

AGE:16

SEX:MALE

COURSE: 4ESO

SCHOOL: SANTA CATALINA ALEJANDRÍA

L1: SPANISH

FATHERS_L1: SPANISH

MOTHERS_L2: SPANISH

LANGUAGE_AT_HOME: SPANISH

AGE_EXPOSURE: 7

SPEAKING_SELF:B1

LISTENING_SELF: B1

READING_SELF:B1

WRITING_SELF: B1

OTHER_LANGUAGE: YES

WHICH_LANG: FRENCH

ENGLISH_MARK_LAST_YEAR:8

STAY_ABROAD: YES

WHERE_STAY?: ENGLAND

WHEN_STAY?: 2011

MONTHS_STAY: 10 DAYS

EXTRAMURAL_INSTRUCTION: YES

WHEN_EXTRAMURAL: SINCE 2003

MONTHS_EXTRAMURAL: 3 TIMES PER WEEK

ADDITIONAL_EXTRAMURAL: YES

WHICH_ADDITIONAL_EXTRAMURAL: READING ON THE INTERNET, LISTENING TO MUSIC

BILINGUAL_PROGRAM: YES 


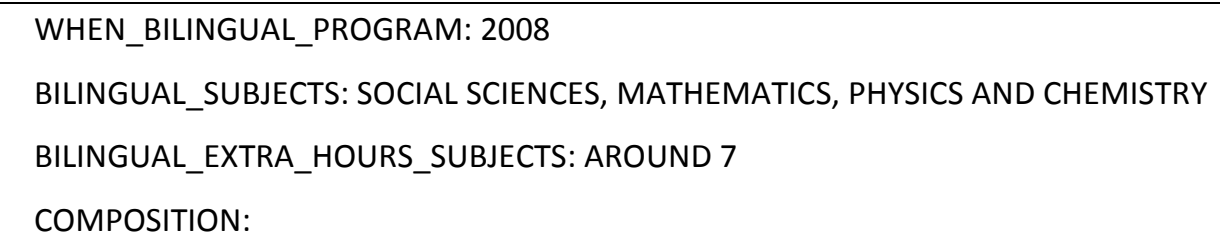

One day, a little boy cought a frog and he put he frog in a vase. It was late so the boy and his dog went to bed. Since he was sleeping the frog scaped. In the morning when the boy and the dog slept up the boy noticed that the frog wasn't in the vase, he started to be worried but luckely the dog could smell the frog so the boy \$_RWU_started \$_INS_decided to look for the frog. The boy was following the dog when he noticed that he was in a forest.. He didn't think twice he went to the forest, he looked insides trees, \$_RWU_behind \$_INS_under rocks. Since he was looking for the frog he found a deer. The deer felt fear of the boy and pushed the boy and the dog, both fell in to the river. The boy swam to a bank of the river and he sat down in a trunk, suddenly he listened some frogs. The boy was happy to have found his frog but he decided to \$_RWU_didn't \$_RWU_cath \$_INS_leaft it. He said goodbye to the frog and returned to his house.

FILE_NAME: B1_4ESO_16_SCA_ADD_AVT

LEVEL: B1

INITIALS:AVT

NICK: SCHWEINSTEIGER

AGE:16

SEX:MALE

COURSE: 4ESO

SCHOOL: SANTA CATALINA ALEJANDRÍA

L1: SPANISH

FATHERS_L1: SPANISH

MOTHERS_L2: SPANISH

LANGUAGE_AT_HOME: SPANISH

AGE_EXPOSURE: 4

SPEAKING_SELF:B2

LISTENING_SELF: B2

READING_SELF:B2

WRITING_SELF: B2

OTHER_LANGUAGE: YES

WHICH_LANG: FRENCH

ENGLISH_MARK_LAST_YEAR:9

STAY_ABROAD: NO 


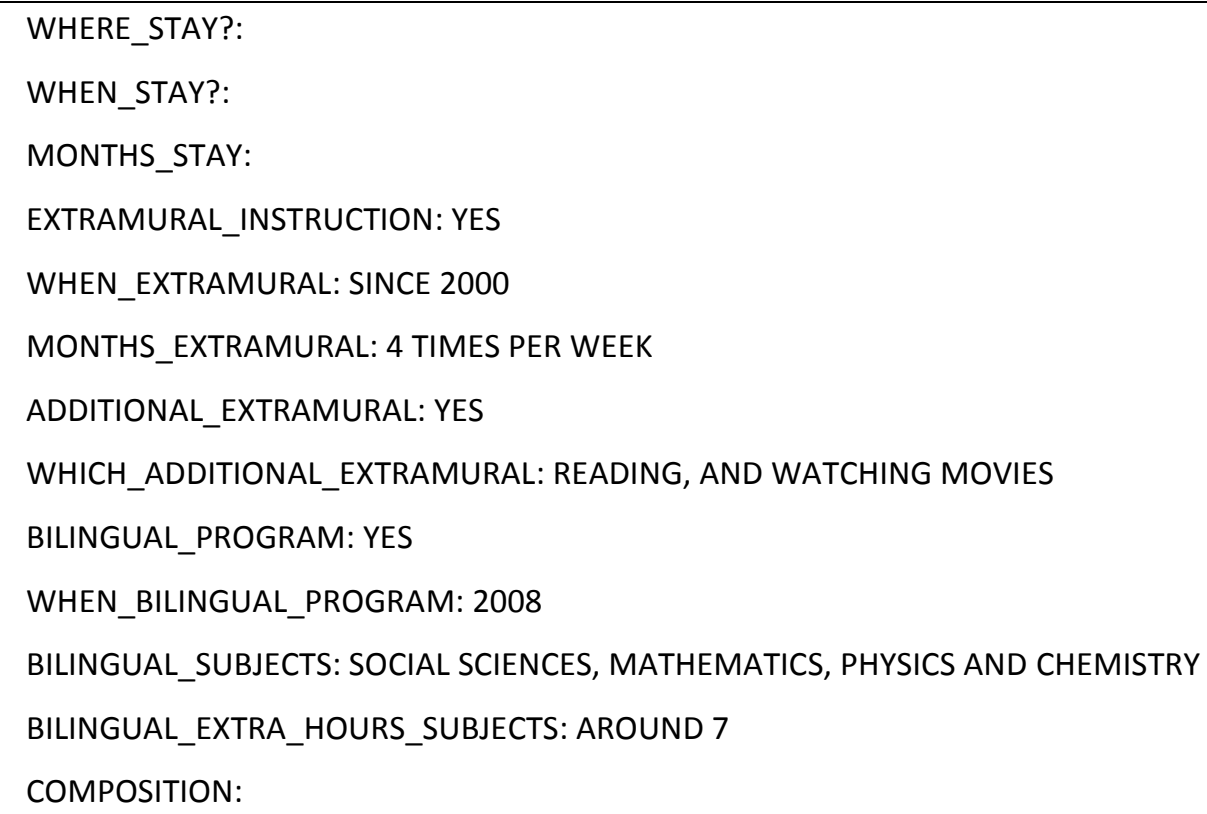

One day, a little boy \$_UNR_¿ was playing with his frog and his dog. At night, when the boy was sleeping, the frog run away from his vase. When the boy was sleeping, the frog run away from his vase. When the boy got up from his bed, he look at the vase ajd the frog wasn't there and after that, the boy was very worried and he looked for him all the day. He shouted in the forest, he looked for him in the tree, and suddenly when he was in a big rock, a deer was on that rock and the boy fell down to a little river, then, when the boy hadn't got \$_UNR_i hope, he found the frog under a trunk with his wife and a lot of little \$_UNR_¿ frogs. Then the boy realise that he had a familly and he \$_UNR_¿ left the frog with his familly, and after these adventures the boy back to his house.

FILE_NAME: B1_4ESO_16_SCA_ADD_DCG

LEVEL: B1

INITIALS:AUG

NICK: APOLO 47

AGE:16

SEX:MALE

COURSE: 4ESO

SCHOOL: SANTA CATALINA ALEJANDRÍA

L1: SPANISH

FATHERS_L1: SPANISH

MOTHERS_L2: SPANISH

LANGUAGE_AT_HOME: SPANISH

AGE_EXPOSURE: 7

SPEAKING_SELF:B1 
LISTENING_SELF: B1

READING_SELF:B1

WRITING_SELF: B1

OTHER_LANGUAGE: YES

WHICH_LANG: FRENCH AND GERMAN

ENGLISH_MARK_LAST_YEAR:9

STAY_ABROAD: NO

WHERE_STAY?:

WHEN_STAY?:

MONTHS STAY: 10 DAYS

EXTRAMURAL_INSTRUCTION: NO

WHEN_EXTRAMURAL:

MONTHS_EXTRAMURAL:

ADDITIONAL_EXTRAMURAL: YES

WHICH_ADDITIONAL_EXTRAMURAL: WATCHING SPONGEBOB

BILINGUAL_PROGRAM: YES

WHEN_BILINGUAL_PROGRAM: 2008

BILINGUAL_SUBJECTS: SOCIAL SCIENCES, MATHEMATICS, PHYSICS AND CHEMISTRY

BILINGUAL_EXTRA_HOURS_SUBJECTS: AROUND 7

COMPOSITION:

One day, Jimy found a frog. He was very happy. He took the frog in a vase and he put it on the floor. This night the frog escaped. The next day he was very worried because the frog was escaped when he was sleeping. He went to the forest to look for his frog. He looked \$_UNR_i in the trees he looked \$_UNR_i beetwen the stone. after he \$_UNR_¿ went to the top of a stone to call his frog but he cought a branch but it was a deer. the dear push the boy. He fell down to the river. Next he clim to a trunk. Sudenly he saw a family of frogs. His frog was there. "Frogy" shout Jimy "you were here" after he took his frog and waved goodbye to the family frog and went back home. END

LE_NAME: B1_4ESO_16_SCA_ADD_HRO

LEVEL: B1

INITIALS:HRO

NICK: HUGO

AGE:16

SEX:MALE

COURSE: 1ㅇACHILLER

SCHOOL: SANTA CATALINA ALEJANDRÍA 
L1: SPANISH

FATHERS_L1: SPANISH

MOTHERS_L2: SPANISH

LANGUAGE_AT_HOME: SPANISH

AGE_EXPOSURE: 8

SPEAKING_SELF:B1

LISTENING_SELF: B1

READING_SELF:B1

WRITING_SELF: B1

OTHER_LANGUAGE: YES

WHICH_LANG: FRENCH

ENGLISH_MARK_LAST_YEAR:10

STAY_ABROAD:YES

WHERE_STAY?: GERMANY

WHEN_STAY?: 2011

MONTHS_STAY: 10 DAYS

EXTRAMURAL_INSTRUCTION: NO

WHEN_EXTRAMURAL:

MONTHS_EXTRAMURAL:

ADDITIONAL_EXTRAMURAL:

WHICH_ADDITIONAL_EXTRAMURAL:

BILINGUAL_PROGRAM: YES

WHEN_BILINGUAL_PROGRAM: 2007

BILINGUAL_SUBJECTS: SOCIAL SCIENCES, MATHEMATICS, PHYSICS AND CHEMISTRY

BILINGUAL_EXTRA_HOURS_SUBJECTS: AROUND 7

COMPOSITION:

One day, I found a frog and I decided to carry it \$_UNR_ ¿ \$_UNR_i my house. I put it in a vase and I slept. When i woke up i discovered that the frog wasn't in the vase! I started to look for it in the forest. My dog was attacked by some bees and he \$_UNR_i escaped from there. I climbed a rock to see better. \$_RWU_and \$_RWU_find \$_RWU_my \$_RWU_frog I held in a branch, but it wasn't a branch, it was a horn of a deer. Suddenly he \$_UNR_i began to ru and I fell \$_RWU_in \$_RWU_the into the water. I thought I was going to die but I \$_RWU_watched caught a trunk and I escaped from the water. Then i discovered \$_RWU_the my frog and its family! I had to wave goodbye.

FILE_NAME: B1_4ESO_16_SCA_ADD_MBP

LEVEL: B1 
INITIALS:MBP

NICK: MARTA

AGE:16

SEX:FEMALE

COURSE: 4ESO

SCHOOL: SANTA CATALINA ALEJANDRÍA

L1: SPANISH

FATHERS_L1: SPANISH

MOTHERS_L2: SPANISH

LANGUAGE_AT_HOME: SPANISH

AGE_EXPOSURE: 4

SPEAKING_SELF:B1

LISTENING_SELF: B1

READING_SELF:B2

WRITING_SELF: B1

OTHER_LANGUAGE: YES

WHICH_LANG: FRENCH

ENGLISH_MARK_LAST_YEAR:10

STAY_ABROAD: YES

WHERE_STAY?: GERMANY (ELF)

WHEN_STAY?: 10 DAYS

MONTHS_STAY: 10 DAYS

EXTRAMURAL_INSTRUCTION: YES

WHEN_EXTRAMURAL: 2005

MONTHS_EXTRAMURAL: 3 TIMES PER WEEK

ADDITIONAL_EXTRAMURAL: YES

WHICH_ADDITIONAL_EXTRAMURAL: WATCHING MOVIES, READING ON THE INTERNET

WHEN_BILINGUAL_PROGRAM: 2008

BILINGUAL_SUBJECTS: SOCIAL SCIENCES, MATHEMATICS, PHYSICS AND CHEMISTRY

BILINGUAL_EXTRA_HOURS_SUBJECTS: AROUND 7

COMPOSITION:

One day, a child was in his bedroom looking at his new pet, a frog. He was very happy for it, but one night while he was sleeping the frog scaped form its vase. \$_UNR_¿ Next day the boy was very sad because his pet wasn't in the bedroom with him, so he decided to look for the frog in the forest. Suddenly when we was looking \$_INS_for \$_INS_the \$_INS_frog and shouting to it, a deer push him and \$_INS_he fell in to the water. Two minutes later he found a trunk \$_UNR_i and behind of it were his frog and all of its family. He was so exciting for find his pet. Finally the history was a happy end. 
FILE_NAME: B1_4ESO_16_SCA_ADD_NQA

LEVEL: B1

INITIALS:NQA

NICK: 96

AGE:16

SEX:MALE

COURSE: 4ESO

SCHOOL: SANTA CATALINA ALEJANDRÍA

L1: SPANISH

FATHERS_L1: SPANISH

MOTHERS_L2: SPANISH

LANGUAGE_AT_HOME: SPANISH

AGE_EXPOSURE: 8

SPEAKING_SELF:B1

LISTENING_SELF: B1

READING_SELF:B1

WRITING_SELF: B1

OTHER_LANGUAGE: YES

WHICH_LANG: FRENCH AND JAPANESE

ENGLISH_MARK_LAST_YEAR:7

STAY_ABROAD: YES

WHERE_STAY?:SCOTLAND

WHEN_STAY?: 2011

MONTHS_STAY: 10 DAYS

EXTRAMURAL_INSTRUCTION: NO

WHEN_EXTRAMURAL:

MONTHS_EXTRAMURAL:

ADDITIONAL_EXTRAMURAL: YES

WHICH_ADDITIONAL_EXTRAMURAL: READING BOOKS AND COMICS, LISTENING TO MUSIC

BILINGUAL_PROGRAM: YES

WHEN_BILINGUAL_PROGRAM: 2008

BILINGUAL_SUBJECTS: SOCIAL SCIENCES, MATHEMATICS, BIOLOGY

BILINGUAL_EXTRA_HOURS_SUBJECTS: AROUND 7

COMPOSITION: 
One day, I was with my frog \$_UNR_¿ watching my new pet, it was a frog. When I \$_UNR_¿ whent to sleep the \$_UNR_i \$_UNR_c \$_UNR_c fro scape of it's vase in the middle of the night. The next day \$_UNR_¿ when I woke up, I saw that the frog \$_UNR_¿ wasn't in the bedroom so I started to looking for because I was worried. We went to the forest and shout its name, I thought \$_UNR_¿ it would came back to me. I held a branch when I was shouting but it wasn't a branch it was \$_INS_deer horn. \$_UNR_¿ The deer pushed me and I fell to the river. I climbed a trunk and I found a \$_UNR_¿ family of frogs. I caught my frog \$_UNR_c and I said goodbye.

FILE_NAME: B1_4ESO_16_SCA_ADD_SMR

LEVEL: B1

INITIALS:SMR

NICK: SARAY

AGE:16

SEX:FEMALE

COURSE: 4토S

SCHOOL: SANTA CATALINA ALEJANDRÍA

L1: SPANISH

FATHERS_L1: SPANISH

MOTHERS_L2: SPANISH

LANGUAGE_AT_HOME: SPANISH

AGE_EXPOSURE: 6

SPEAKING_SELF:B1

LISTENING_SELF: B1

READING_SELF:B2

WRITING_SELF: B1

OTHER_LANGUAGE: YES

WHICH_LANG: FRENCH

ENGLISH_MARK_LAST_YEAR:8

STAY_ABROAD: NO

WHERE_STAY?:

WHEN_STAY?:

MONTHS_STAY:

EXTRAMURAL_INSTRUCTION: YES

WHEN_EXTRAMURAL: SINCE 2002

MONTHS_EXTRAMURAL: 3 TIMES PER WEEK

ADDITIONAL_EXTRAMURAL: YES

WHICH_ADDITIONAL_EXTRAMURAL: WATCHING MOVIES, LISTENING TO MUSIC 


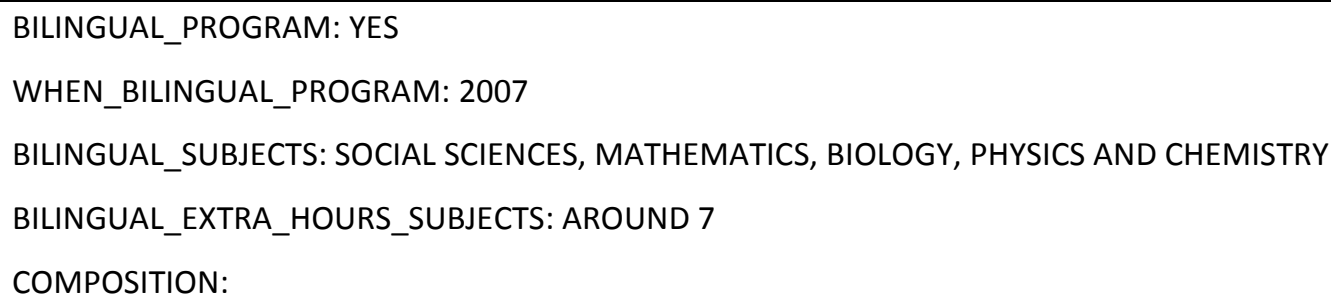

One day, Peter saw with dog a frog. The frog stayed in a vase in Peter's room. When Peter slept in the night his frog scaped. Next day in the morning when Peter wake up he looked that his frog wasn't in the vase so he was worried and Peter started to look for his frog. He shout and look for in the forest with his dog but nothing. When he looked for his frog he found a deer and he arappea into a river. Peter was hold in a branch that is was in the river. His dog found Peter and in the same zone that Peter stayed there were a lot of frogs. He found his frog! The frog was with he family in the river. Peter and his dog went to Peter's house with his frog. The frog stayed in the Peter's hand. Both wave goodbye to the frog 's family, they arrived at home together. The end

FILE_NAME: B1_4ESO_16_SCA_ADD_TTI

LEVEL: B1

INITIALS:TTI

NICK: TERESA

AGE:16

SEX:FEMALE

COURSE: 4ESO

SCHOOL: SANTA CATALINA ALEJANDRÍA

L1: SPANISH

FATHERS_L1: SPANISH

MOTHERS_L2: SPANISH

LANGUAGE_AT_HOME: SPANISH

AGE_EXPOSURE: 5

SPEAKING_SELF:B1

LISTENING_SELF: B2

READING_SELF:C1

WRITING_SELF: B1

OTHER_LANGUAGE: YES

WHICH_LANG: FRENCH

ENGLISH_MARK_LAST_YEAR:8

STAY_ABROAD: NO

WHERE_STAY?: 
WHEN_STAY?:

MONTHS_STAY: 10 DAYS

EXTRAMURAL_INSTRUCTION: NO

WHEN_EXTRAMURAL:

MONTHS_EXTRAMURAL:

ADDITIONAL_EXTRAMURAL: NO

WHICH_ADDITIONAL_EXTRAMURAL:

BILINGUAL_PROGRAM: YES

WHEN_BILINGUAL_PROGRAM: 2008

BILINGUAL_SUBJECTS: SOCIAL SCIENCES, MATHEMATICS, PHYSICS AND CHEMISTRY

BILINGUAL_EXTRA_HOURS_SUBJECTS: AROUND 7

COMPOSITION:

One day, a boy that was sitting with his dog \$_RWU_near \$_RWU_of \$_RWU_his \$_RWU_bed next to his bed. They were watching on vase, whose vase contained a green frog, whose frog was a present. When the boy went to the bed, the frog escaped of the vase. When the boy woke the frog was missing. A few days later, the boy decided \$_RWU_went to go to look for the frog at the forest. He looked a lot of time, but \$_RWU_s he didn't see anything. The bo was sad, and he decided to go back to his house with his dog, but without the frog. When the boy go back to his house, he was trip over with a rock, behind the rock was the frog with anothers littles frog! the frog has had a baby's frog. The boy watching that the frog was so happy with his new family, he decided leave it in the forest. The boy go back to his house but he \$_RWU_didn't wasn't sad.

FILE_NAME: B1_4ESO_16_SCA_ADD_YAV

LEVEL: B1

INITIALS:YAV

NICK: DYV

AGE:16

SEX:FEMALE

COURSE: 4ESO

SCHOOL: SANTA CATALINA ALEJANDRÍA

L1: SPANISH

FATHERS_L1: SPANISH

MOTHERS_L2: SPANISH

LANGUAGE_AT_HOME: SPANISH AND SIGN LANGUAGE

AGE_EXPOSURE: 8

SPEAKING_SELF:B1 


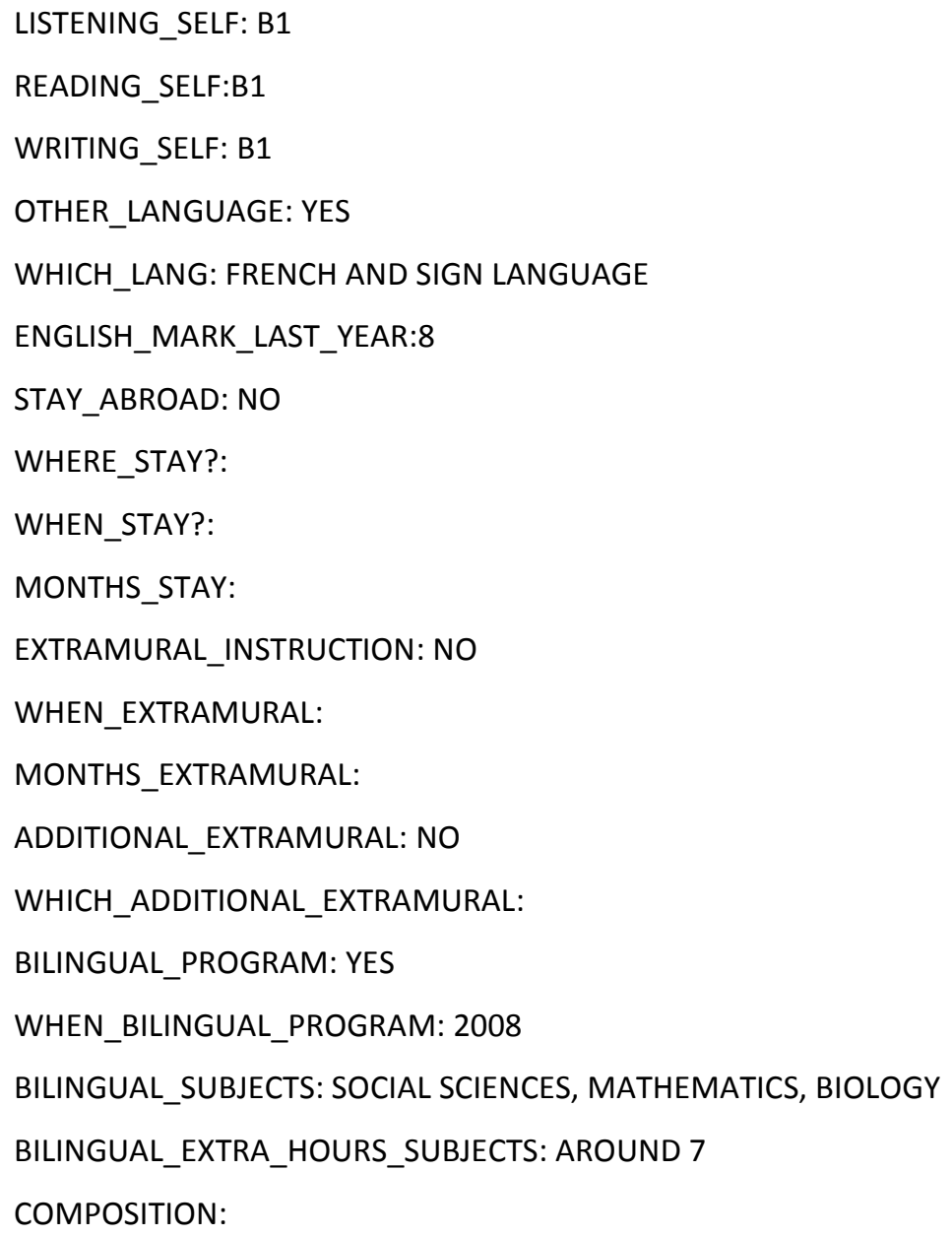

One day, I was with my dog in my bedroom. I was playing with him. I have one frog too and this day put the frog in a vase, and put the vase in the floor too. The frog began to look at the bedroom and escaped the his vase. The next day, when I get up, I was going to look my frog but the frog doesn't stay in the vase. I felt worried because the frog was my favourite pet. I was going to the forest for look for my frog and started to shout his name with my dog. For look better I went to the top of the rock and I continued shouted. In this rock I held woth the branches of one tree but this branches \$_UNR_¿ wasn't branches because was horns, deer's horns. The deer pushed me and drop on the deer, When the deer look at me, pushed me into the river and fall in the river. I was under the water and I can't breath. When I was in the river I \$_RWU_catch caught one trunk. In the other part of this trunk was the family of my frog and my frog too. I caught my frog with my hand and wave goodbye \$_RWU_at a the frog's family. I went to my house with my forg and my $\operatorname{dog} \ldots$

FILE_NAME: B2_1BAC_16_SCA_ADD_AJS

LEVEL: B2

INITIALS:AJS

NICK:ANA 
AGE:16

SEX:FEMALE

COURSE: 1ㅇACHILLER

SCHOOL: SANTA CATALINA ALEJANDRÍA

L1: SPANISH

FATHERS_L1: SPANISH

MOTHERS_L2: SPANISH

LANGUAGE_AT_HOME: SPANISH

AGE_EXPOSURE: 8

SPEAKING_SELF:B1

LISTENING_SELF: B2

READING_SELF:B2

WRITING_SELF: B2

OTHER_LANGUAGE: YES

WHICH_LANG: FRENCH

ENGLISH_MARK_LAST_YEAR: 9

STAY_ABROAD: YES

WHERE_STAY?: ENGLAND

WHEN_STAY?: 2010

MONTHS_STAY: 10 DAYS

EXTRAMURAL_INSTRUCTION: NO

WHEN_EXTRAMURAL:

MONTHS_EXTRAMURAL:

ADDITIONAL_EXTRAMURAL: YES

WHICH_ADDITIONAL_EXTRAMURAL: LISTENING TO MUSIC

BILINGUAL_PROGRAM: YES

WHEN_BILINGUAL_PROGRAM: 2007

BILINGUAL_SUBJECTS: CMC, INTEGRATED PROJECT

BILINGUAL_EXTRA_HOURS_SUBJECTS: 4

COMPOSITION:

One day, a boy called Billy found a frog in the street and he \$_UNR_i toke it. \$_INS_in his house, Billy put the frog in a vase and later, he went to sleep. In the middle \$_UNR_i of the night, while Billy \$_RWU_sleep slept, the frog escape and went our of the house. The next \$_RWU_mornig morning, Billy was worried and sad because he realised \$_UNR_i that the frog went out. Then, Billy and his dog went to the forest to llok for his new pet. Two hours later, he continued \$_RWU_to in the forest but he didn't found it yet. He looked behind the rocks, on the trunk and the branches but without results. Later, he was satting in a rocks where a deer pushed him. Billy was afraid, he showed and cried. Then he dropped into a river. 
Behind a trunk, he heared noises and he went to investigate. Suddenly \$_UNR_¿ he was very happy, he has found the frog with his family. He realised that it was better to leave the frog \$_UNR_¿ in the forest with his family. Finally he \$_RWU_wave \$_INS_said goodbye and retourned at home.

INITIALS:AOR

NICK:Luís ÁNGELA

AGE:16

SEX:FEMALE

COURSE: 19BACHILLER

SCHOOL: SANTA CATALINA ALEJANDRÍA

L1: SPANISH

FATHERS_L1: SPANISH

MOTHERS_L2: SPANISH

LANGUAGE_AT_HOME: SPANISH

AGE_EXPOSURE: 4

SPEAKING_SELF:B2

LISTENING_SELF: B1

READING_SELF:B1

WRITING_SELF: B1

OTHER_LANGUAGE: YES

WHICH_LANG: FRENCH

ENGLISH_MARK_LAST_YEAR:10

STAY_ABROAD: YES

WHERE_STAY?: ENGLAND

WHEN_STAY?: 2010

MONTHS_STAY: 2 WEEKS

EXTRAMURAL_INSTRUCTION: YES

WHEN_EXTRAMURAL: 12 TIMES PER MONTH

MONTHS_EXTRAMURAL: 44 MONTHS

ADDITIONAL_EXTRAMURAL: YES

WHICH_ADDITIONAL_EXTRAMURAL: TALKING TO MY NATIVES FRIENDS AND LISTENING TO MUSIC, USING MY PHONE IN ENGLISH

BILINGUAL_PROGRAM: YES

WHEN_BILINGUAL_PROGRAM: 2007

BILINGUAL_SUBJECTS: CMC, INTEGRATED PROJECT

BILINGUAL_EXTRA_HOURS_SUBJECTS: 4 


\section{COMPOSITION:}

One day, a boy was playing in the forest when he found a frog. He took ot and he looked after it during a month. One night, while he was sleeping, the frog escaped and \$_RWU_when he_during many days, he was worried about it so he decided to look for the frog. He went to te forest with his dog and he looked for the frog in the all forest but, he didn't find it. on his borthday's day, his mother had a surprised for him. She S_RWU_had have bought a new frog but he \$_RWU_has continuou \$_RWU_continoou \$_RWU_continuou looking for the first frog in every trunk on under the stones because he wanted that his two frogs \$_RWU_were became friends. So, he \$_RWU_¿ looked for his frog in another part of the forest. He was having a look around a stone when, suddenly a deer appeared and push the boy so the boy felt in a river. He swam to the cost and there, he found his old frog! He was very happy because his dream became true, his two frogs \$_RWU_togheter together.

FILE_NAME: B2_1BAC_16_SCA_ADD_ESC

LEVEL: B2

INITIALS:ESC

NICK:ELVIRA

AGE:16

SEX:FEMALE

COURSE: 1BACHILLER

SCHOOL: SANTA CATALINA ALEJANDRÍA

L1: SPANISH

FATHERS_L1: SPANISH

MOTHERS_L2: SPANISH

LANGUAGE_AT_HOME: SPANISH

AGE_EXPOSURE: 7

SPEAKING_SELF:B1

LISTENING_SELF: B1

READING_SELF:B2

WRITING_SELF: B1

OTHER_LANGUAGE: YES

WHICH_LANG: FRENCH

ENGLISH_MARK_LAST_YEAR: 10

STAY_ABROAD: YES

WHERE_STAY?: ENGLAND

WHEN_STAY?: 2009 
MONTHS_STAY: 10 DAYS

EXTRAMURAL_INSTRUCTION: NO

WHEN_EXTRAMURAL:

MONTHS_EXTRAMURAL:

ADDITIONAL_EXTRAMURAL:YES

WHICH_ADDITIONAL_EXTRAMURAL: WATCHING MOVIES

BILINGUAL_PROGRAM: YES

WHEN_BILINGUAL_PROGRAM: 2007

BILINGUAL_SUBJECTS: CMC, INTEGRATED PROJECT

BILINGUAL_EXTRA_HOURS_SUBJECTS: 4

COMPOSITION:

One day, a boy found a frog in a river and he decided to adopt it as a pet. In the nigh, the frog escaped. When the boy woke up \$_RWU_wake woke up \$_RWU_the he was worried about \$_RWU_her it so he and his dog went to look fot it in the forest. the boy look into the trees, he shouted its name but he didn't dound it. Suddenly, while he was shouting, a deer heared him and pushed him and his dog. They \$_RWU_fell fall into a rive, \$_RWU_a The dog helped the boy to find a trunk that was next to the river \$_Ins_shore. The boy was very surprised because behind the trunk he found a family of frogs and \$_RWU_he his frog was there. He asked the frog if it wanted to come back to the house with him and the frog \$_RWU_aceepted accepted. They \$_RWU_sei say goodbye to the \$_RWU_others other frogs and went to the house \$_RWU_toghther together. Now they are very happy living together and they are good friends.

FILE_NAME: B2_1BAC_16_SCA_ADD_LCG

LEVEL: B2

INITIALS:LCG

NICK: FABERRY

AGE:16

SEX:FEMALE

COURSE: 19BACHILLER

SCHOOL: SANTA CATALINA ALEJANDRÍA

L1: SPANISH

FATHERS_L1: SPANISH

MOTHERS_L2: SPANISH

LANGUAGE_AT_HOME: SPANISH

AGE_EXPOSURE: 8 
SPEAKING_SELF:A2

LISTENING_SELF: B1

READING_SELF:A2

WRITING_SELF: A2

OTHER_LANGUAGE: YES

WHICH_LANG: FRENCH

ENGLISH_MARK_LAST_YEAR: 7

STAY_ABROAD: NO

WHERE_STAY?:

WHEN_STAY?:

MONTHS_STAY:

EXTRAMURAL_INSTRUCTION: NO

WHEN_EXTRAMURAL:

MONTHS_EXTRAMURAL:

ADDITIONAL_EXTRAMURAL: YES

WHICH_ADDITIONAL_EXTRAMURAL: READING MAGAZINES, WATCHING TV SHOWS, LISTENING TO MUSIC

BILINGUAL_PROGRAM: YES

WHEN_BILINGUAL_PROGRAM: 2007

BILINGUAL_SUBJECTS: CMC, INTEGRATED PROJECT

BILINGUAL_EXTRA_HOURS_SUBJECTS: 4

COMPOSITION:

One day, a boy, who's name was Jack, have a frog in his bedroom, he was \$_RWU_ ¿ looking at the frog by the dog smell it, at the night the boy \$_Ins_was sleeping in his bed when the frog escaped. The next morning \$_RWU_the bo Jack was worried about the frog and the started looking for it, with his dog. They went to the forest and shouted "'frog, frog". The young boy went up $\$ \_R W U_{-} \dot{c}$ to the brach of a tree \$_RWU_and by the time some bees went to them. Jack was on a rock and pushed \$_RWU_a trunk two branchs, but the found a deer which pushed him $\$ \_R W U \_\dot{i}$ ino the river. The dog falled with him and they get wet. They found a trunk and behind that trunk, they found the frog with $\$ \_R W U_{-} \dot{i}$ it familly. Jack and his dog leaved the happy familly and they said them goodbye with the hand.

NICK:Luís Luisca

AGE:16

SEX:MALE

COURSE: 19BACHILLER

SCHOOL: SANTA CATALINA ALEJANDRÍA 
L1: SPANISH

FATHERS_L1: SPANISH

MOTHERS_L2: SPANISH

LANGUAGE_AT_HOME: SPANISH

AGE_EXPOSURE: 5

SPEAKING_SELF:B1

LISTENING_SELF: B1

READING_SELF:B1

WRITING_SELF: B1

OTHER_LANGUAGE: YES

WHICH_LANG: FRENCH

ENGLISH_MARK_LAST_YEAR:8

STAY_ABROAD: YES

WHERE_STAY?: ENGLAND

WHEN_STAY?: 2011

MONTHS_STAY: 2 WEEKS

EXTRAMURAL_INSTRUCTION: YES

WHEN_EXTRAMURAL: 12 TIMES PER MONTH

MONTHS_EXTRAMURAL: 48 MONTHS

ADDITIONAL_EXTRAMURAL: YES

WHICH_ADDITIONAL_EXTRAMURAL:

BILINGUAL_PROGRAM: YES

WHEN_BILINGUAL_PROGRAM: 2007

BILINGUAL_SUBJECTS: CMC, INTEGRATED PROJECT

BILINGUAL_EXTRA_HOURS_SUBJECTS: 4

COMPOSITION:

One day, a little boy was playing in his \$_RWU_bedroom bedroom with his dog, when suddenly, his father nocked the door and went into the \$_RWU_bedroom bedroom. His father \$_RWU_hi give him a present, it was a \$_RWU_fog frog the he had found in the river. The boy \$_RWU_and his two pets were playing all the eve_ played with his two pets all day. This night \$_RWU_at by the time he was sleeping, the frog escaped. Next day, when he \$_RWU_wake woke up he saw that his frog escaped. The boy was very worried and he \$_RWU_c decided to go to the forest they couldn't found it. \$_RWU_fhort furthermore a deer pushed them and they $\$ \_R W U \_$fall fell down in a river, when they found the $\$ \_R W U \_i$ frog. The discovered \$_RWU_c frog's family, so the left the frog with them and wave goobbye.

FILE_NAME: B2_1BAC_16_SCA_ADD_LECR 
LEVEL: B1

INITIALS:LECR

NICK:Luís Enrique

AGE:16

SEX:MALE

COURSE: 1BACHILLER

SCHOOL: SANTA CATALINA ALEJANDRÍA

L1: SPANISH

FATHERS_L1: SPANISH

MOTHERS_L2: SPANISH

LANGUAGE_AT_HOME: SPANISH

AGE_EXPOSURE: 9

SPEAKING_SELF:A1

LISTENING_SELF: A1

READING_SELF:A1

WRITING_SELF: A1

OTHER_LANGUAGE: YES

WHICH_LANG: FRENCH

ENGLISH_MARK_LAST_YEAR:7

STAY_ABROAD: NO

WHERE_STAY?:

WHEN_STAY?:

MONTHS_STAY:

EXTRAMURAL_INSTRUCTION: YES

WHEN_EXTRAMURAL: 8 TIMES PER MONTH

MONTHS_EXTRAMURAL: 1 MONTH

ADDITIONAL_EXTRAMURAL: NO

WHICH_ADDITIONAL_EXTRAMURAL:

BILINGUAL_PROGRAM: YES

WHEN_BILINGUAL_PROGRAM: 2007

BILINGUAL_SUBJECTS: CMC, INTEGRATED PROJECT

BILINGUAL_EXTRA_HOURS_SUBJECTS: 4

COMPOSITION:

One day, a boy had a frog, The frog \$_RWU_jump out at the floor scape for the vase. The next day the bot didn't see the frog in the vase, and he look for in the forest. He \$_RWU_look for shouted in the forest and he didn't see. The boy \$_RWU_w was worried \$_RWU_for of the frog. The boy \$_SWU_push pushed a branch. \$_RWU_i but the branch \$_RWU_theer there is a deer. The deer hold the boy in the hearl and 
\$_RWU_i the deer pushed a boy and he fall in the river. The dog safe of the water at the boy, $\$ \_R W U_{-} \dot{ }$ and he found the \$_RWU_family's frog and he left in the trunk and he and waved goodbye. The boy went to the house and he felt very sad for the $\$ \_R$.WU_c frog.

FILE_NAME: B2_1BAC_16_SCA_ADD_LLT

LEVEL: B2

INITIALS:LLT

NICK:Luís lauli

AGE:16

SEX:FEMALE

COURSE: 19BACHILLER

SCHOOL: SANTA CATALINA ALEJANDRÍA

L1: SPANISH

FATHERS_L1: SPANISH

MOTHERS_L2: SPANISH

LANGUAGE_AT_HOME: SPANISH

AGE_EXPOSURE: 3

SPEAKING_SELF:B1

LISTENING_SELF: B1

READING_SELF:B1

WRITING_SELF: B1

OTHER_LANGUAGE: YES

WHICH_LANG: FRENCH

ENGLISH_MARK_LAST_YEAR:10

STAY_ABROAD: YES

WHERE_STAY?: ENGLAND

WHEN_STAY?: 2011

MONTHS_STAY: 10 days

EXTRAMURAL_INSTRUCTION: NO

WHEN_EXTRAMURAL:

MONTHS_EXTRAMURAL:

ADDITIONAL_EXTRAMURAL: YES

WHICH_ADDITIONAL_EXTRAMURAL:WATCHING MOVIES, LISTENING TO MUSIC AND READING

BILINGUAL_PROGRAM: YES

WHEN_BILINGUAL_PROGRAM: 2007

BILINGUAL_SUBJECTS: CMC, INTEGRATED PROJECT

BILINGUAL_EXTRA_HOURS_SUBJECTS: 4 


\section{COMPOSITION:}

One day, Paul was sitting in his bedroom looking at his frog with his dog \$_RWU_while and he went to bed. While Paul was sleeping, his frog ran out of the bottle and it scaped. The next morning, when Paul noticed the frog wasn't in the bottle, he felt vert sad and decided to look for him with hs dog. The dog and Paul went to the forest and called the frog, but they didn't found it. The look for \$_RWU_c in trees, behind and under the rocks, but \$_RWU_they there wasn't lucky. Suddenly, a deer appeared and pushed the boy and the dog to the lake. Paul noticed that the frog was next to the trunk \$_RWU_a with his family. Then, Paul understood that he can't have \$_RWU_c the frog in a bottle, becasue we must be with his family. \$_RWU_and Finally, Paul and his dog left the forest and waved goodbye to the frog and his family.

FILE_NAME: B2_1BAC_16_SCA_ADD_LRV

LEVEL: B2

INITIALS:LRV

NICK:Luís SETE

AGE:16

SEX:MALE

COURSE: 1BACHILLER

SCHOOL: SANTA CATALINA ALEJANDRÍA

L1: SPANISH

FATHERS_L1: SPANISH

MOTHERS_L2: SPANISH

LANGUAGE_AT_HOME: SPANISH

AGE_EXPOSURE: 6

SPEAKING_SELF:B1

LISTENING_SELF: B1

READING_SELF:B1

WRITING_SELF: B1

OTHER_LANGUAGE: YES

WHICH_LANG: FRENCH

ENGLISH_MARK_LAST_YEAR:9

STAY_ABROAD:YES

WHERE_STAY?: ENGLAND

WHEN_STAY?: 2010

MONTHS_STAY: 2 WEEKS

EXTRAMURAL_INSTRUCTION: YES 
WHEN_EXTRAMURAL: 12 TIMES PER MONTH

MONTHS_EXTRAMURAL: 32 MONTHS

ADDITIONAL_EXTRAMURAL: NO

WHICH_ADDITIONAL_EXTRAMURAL:

BILINGUAL_PROGRAM: YES

WHEN_BILINGUAL_PROGRAM: 2007

BILINGUAL_SUBJECTS: CMC, INTEGRATED PROJECT

BILINGUAL_EXTRA_HOURS_SUBJECTS: 4

COMPOSITION:

One day, a boy had a frog in a vase. He was very happy because of the frog. In the night when the boy was sleeping, the frog escaped and run away. The day after the boy was sad becasue the frog wasn't there, he looked for her all the day and be climb a rock. When he was in the neck, a deer pushed him and his dog to the river. When they went to the surface, the boy realised that the frog had a family, and he \$_RWU_went come back home and wave goodbye to his friendly frog.

FILE_NAME: B2_1BAC_16_SCA_ADD_MDD

LEVEL: B2

INITIALS:MDD

NICK:MARINA

AGE:16

SEX:FEMALE

COURSE: 1BACHILLER

SCHOOL: SANTA CATALINA ALEJANDRÍA

L1: SPANISH

FATHERS_L1: SPANISH

MOTHERS_L2: SPANISH

LANGUAGE_AT_HOME: SPANISH

AGE_EXPOSURE: 6

SPEAKING_SELF:B1

LISTENING_SELF: B2

READING_SELF:B2

WRITING_SELF: B1

OTHER_LANGUAGE: YES

WHICH_LANG: FRENCH

ENGLISH_MARK_LAST_YEAR: 9

STAY_ABROAD: YES 


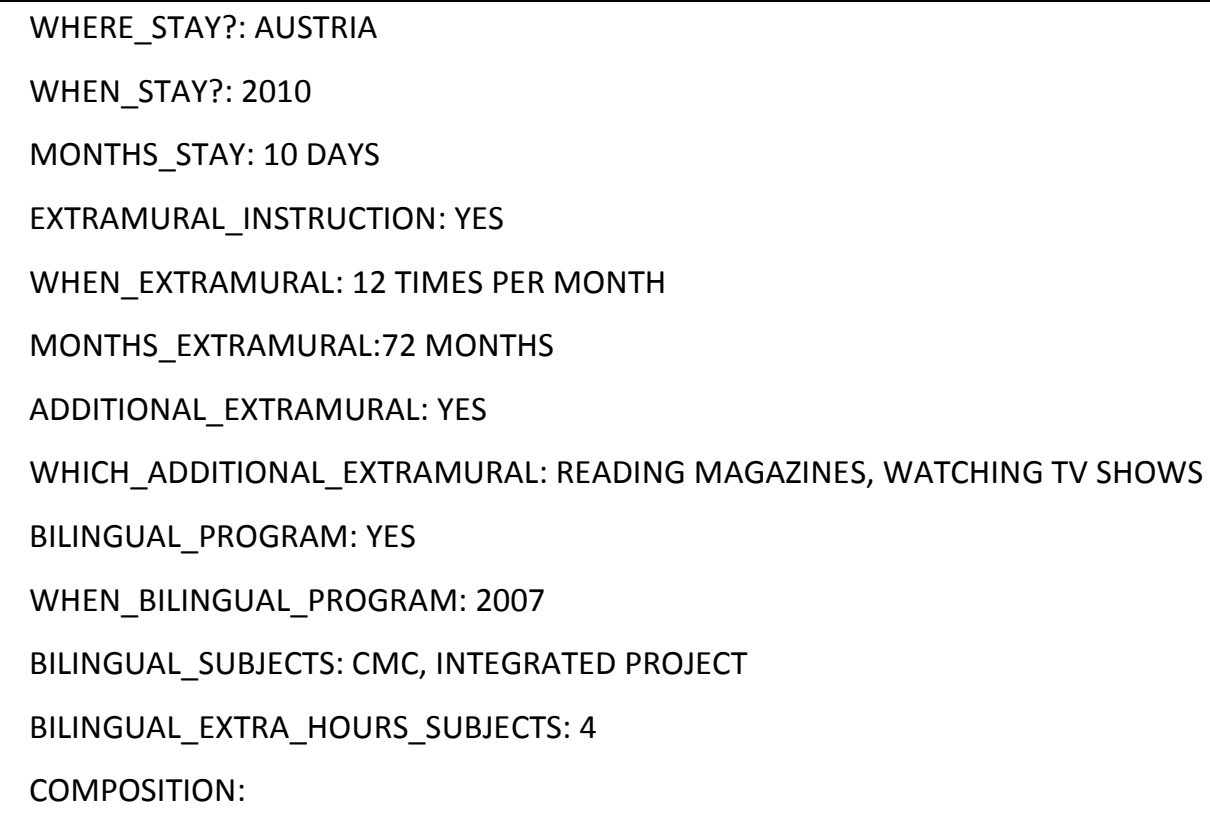

One day, a boy was resting at his bedroom with his two pets wondering what he will do without them becasue he use to play with them. When the boy went to the bed the frog jumped out of the vase and go away. Next morning, when the boy woke up he realised that the frog wasn't in the vase so, he became really sad and he decided to go to the countryside to tray to found it. He started to \$_RWU_souht shout but it doesn't help, then he looked in the trees, in the rocks but the frog wasn't there. When \$_RWU_we he was standing on a rock, a deer kick him and he foll down on a river. \$_RWU_Finally when he could_He arrive to a trunk \$_RWU_¿ so he was safety. Suddenly when he was staying there je look behind the trunk and he discovered that the frog was there. He saw that frog was not lonely, \$_RWU_c it was with \$_RWU_his its family. So he decided to go away and returned home. The frogs stay in the river and he wave goodbye

FILE_NAME: B2_1BAC_16_SCA_ADD_MPM

LEVEL: B2

INITIALS:MPM

NICK:MERY

AGE:16

SEX:FEMALE

COURSE: 1으ACHILLER

SCHOOL: SANTA CATALINA ALEJANDRÍA

L1: SPANISH

FATHERS_L1: SPANISH

MOTHERS_L2: SPANISH

LANGUAGE_AT_HOME: SPANISH 


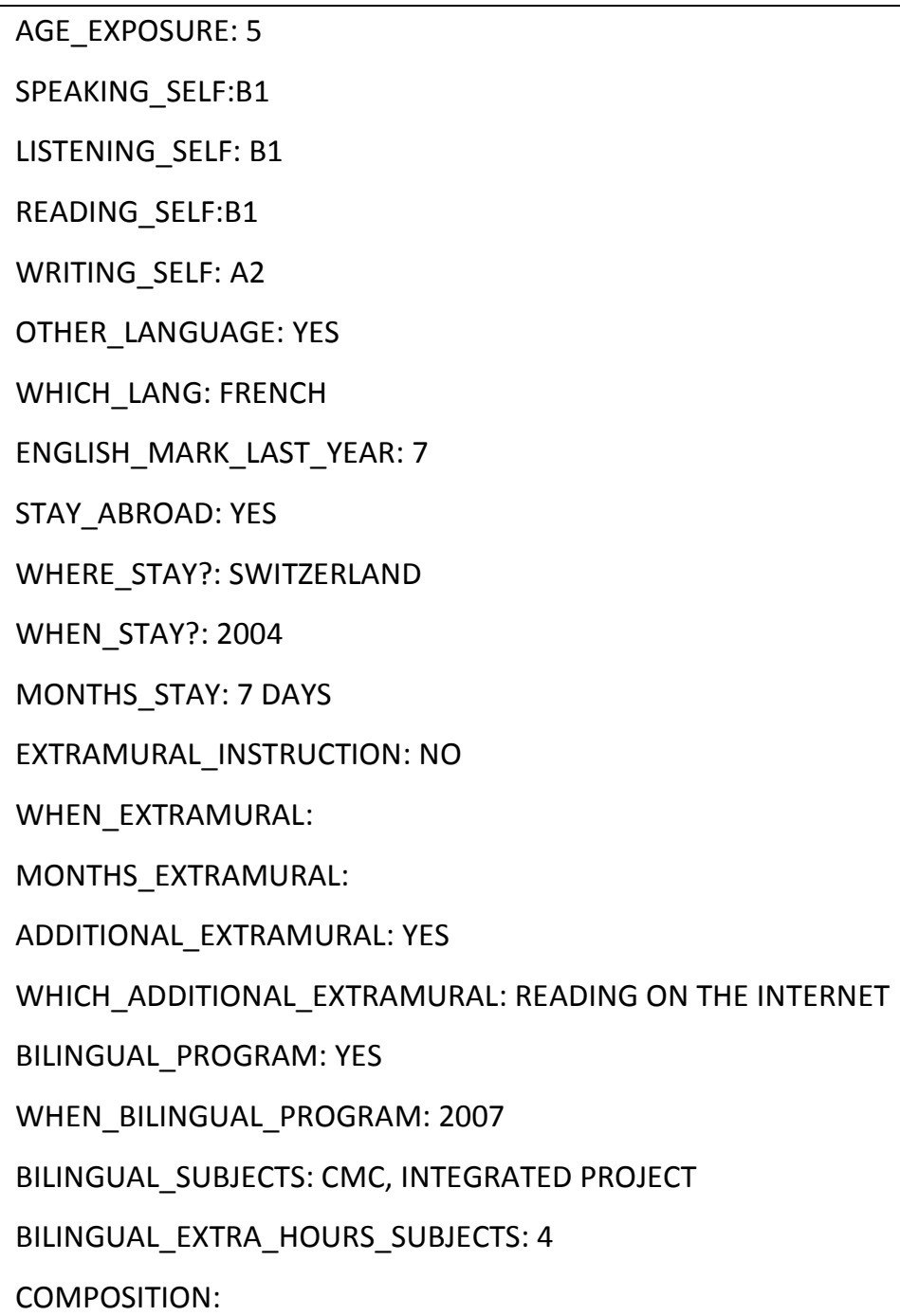

One day, A little boy bought a frog, he was so happy for his new pet, he and his dog Toby were all day staying at boy's room looking at the frog, but, in the night the boy, Dany, and his dog fall asleep. In the morning they woke up and they realised that the frog has escaped, Toby started to look for the frog going everywhere in \$_RWU_¿ Dani's bedroom and smelling the vase wher the frog was. Dani and Toby were so unhappy about their missing frog, so they decided to go out and look for the frog in the countryside, they were getting worried about the frog, they didn't know of she was ok. The boy shouted loud time to time, but the boy wasn't there, they decided to move on and look otherway, while they boy was shouting worried, Toby found many bees on the floor, they were flying around Toby; it appeared like they were friends, Toby climbed a rock \$_RWU_¿ the was still shouting \$RWU_i and in a few seconds a deer appeared in front of him, the deer took dani and toby and pushed them into a rver, they fall down and get into the river, luckily they gwere ok, they climbed a trunk and found a family's frog. \$_RWU_now Now the understood why she leaved their home and thought it was better if they leave them, so they \$_RWU_say said goodbye to their frog and her family and return home calm and pleased about the frog.

FILE_NAME: B2_1BAC_16_SCA_ADD_MS 
LEVEL: B2

INITIALS:MS

NICK:MARÍA

AGE:16

SEX:FEMALE

COURSE: 1BACHILLER

SCHOOL: SANTA CATALINA ALEJANDRÍA

L1: SPANISH

FATHERS_L1: SPANISH

MOTHERS_L2: SPANISH

LANGUAGE_AT_HOME: SPANISH

AGE_EXPOSURE: 5

SPEAKING_SELF:B2

LISTENING_SELF: B2

READING_SELF:B1

WRITING_SELF: B2

OTHER_LANGUAGE: YES

WHICH_LANG: FRENCH

ENGLISH_MARK_LAST_YEAR:10

STAY_ABROAD: YES

WHERE_STAY?: ENGLAND

WHEN_STAY?: 2011

MONTHS_STAY: 15 DAYS

EXTRAMURAL_INSTRUCTION: YES

WHEN_EXTRAMURAL: 3HOURS/WEEK

MONTHS_EXTRAMURAL: 10 YEARS

ADDITIONAL_EXTRAMURAL: NO

WHICH_ADDITIONAL_EXTRAMURAL:

BILINGUAL_PROGRAM: YES

WHEN_BILINGUAL_PROGRAM: 2007

BILINGUAL_SUBJECTS: CMC, INTEGRATED PROJECT

BILINGUAL_EXTRA_HOURS_SUBJECTS: 4

COMPOSITION:

One day, a boy went to a trip with his father to get a frog because it was his bithday and had always wanted to have a frog \$_RWU_i so that he could call it \$_RWU_Gut Gustave. He had heard that his friend got one from the river behind their house, so \$_RWU_the his father and him went there. He choosed the one he liked the most an he brought it to his home, the boy also had a dog, and \$_RWU_the Gustave was 
frightened of him, so that night, the frog decided not to continue at the house, becasue he was very small and he missed a lot his family. The next afternoon, when the boy got up, he saw the frog wasn't in the bottle, and he decided to go with his dog to the river and look for it. But the frog was hidden behind a rock, and they didn't see it. While they were looking for it, a group of bees attacketd the dog. At the end the boy decided to get another frog that wasn't so small so that it won't miss its family. The frog was very happy with Gstave II, but the frog not so much

FILE_NAME: B2_1BAC_16_SCA_ADD_MSR

LEVEL: B2

INITIALS:LGCH

NICK:Luís PARÍS

AGE:16

SEX:MALE

COURSE: 1ㅇACHILLER

SCHOOL: SANTA CATALINA ALEJANDRÍA

L1: SPANISH

FATHERS_L1: SPANISH

MOTHERS_L2: SPANISH

LANGUAGE_AT_HOME: SPANISH

AGE_EXPOSURE: 7

SPEAKING_SELF:B2

LISTENING_SELF: C1

READING_SELF:C1

WRITING_SELF: C1

OTHER_LANGUAGE: YES

WHICH_LANG: FRENCH

ENGLISH_MARK_LAST_YEAR:10

STAY_ABROAD: YES

WHERE_STAY?: ENGLAND

WHEN_STAY?: 2011

MONTHS_STAY: 2 WEEKS

EXTRAMURAL_INSTRUCTION: NO

WHEN_EXTRAMURAL:

MONTHS_EXTRAMURAL:

ADDITIONAL_EXTRAMURAL: YES

WHICH_ADDITIONAL_EXTRAMURAL: TALKING TO MY NATIVES FRIENDS AND LISTENING TO MUSIC BILINGUAL_PROGRAM: YES 


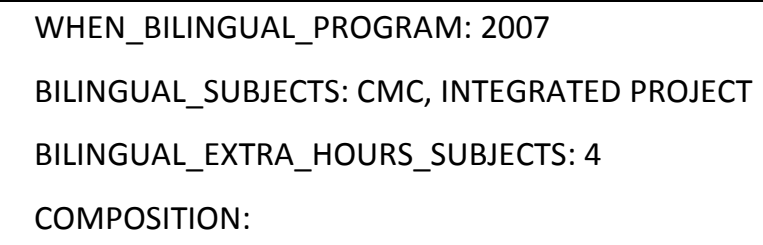

One day, there was a boy in his bedroom with its dog, called Clue and a new frog. It was very late so the boy called Maria decided to sleep. While he was sleeping, the frog escaped from the vase. In the morning, Mario saw that the frog wasn't there, so he decided to look for it. He went to the \$_RWU_country forest and he started to shout, he wanted found its frog! He looked behind the trees, \$_RWU_on a shore_ and when he was on a shorea deer pushed him and he fell in a river. He was a little scary and he helped himself with a trunk. When he was on the trunk, he saw the frog with all its family. It missed them! He caught the dog and they come back to home.

FILE_NAME: B2_1BAC_17_SCA_ADD_AOD

LEVEL: B2

INITIALS:AOD

NICK:Luís Amelia

AGE:17

SEX:FEMALE

COURSE: 1ㅇACHILLER

SCHOOL: SANTA CATALINA ALEJANDRÍA

L1: SPANISH

FATHERS_L1: SPANISH

MOTHERS_L2: SPANISH

LANGUAGE_AT_HOME: SPANISH

AGE_EXPOSURE: 3

SPEAKING_SELF:B1

LISTENING_SELF: B1

READING_SELF:B1

WRITING_SELF: B1

OTHER_LANGUAGE: YES

WHICH_LANG: FRENCH

ENGLISH_MARK_LAST_YEAR:9

STAY_ABROAD: YES

WHERE_STAY?: ENGLAND

WHEN_STAY?: 2011 AND 2009

MONTHS_STAY: 1 MONTH 
EXTRAMURAL_INSTRUCTION: YES

WHEN_EXTRAMURAL: 12 TIMES PER MONTH

MONTHS_EXTRAMURAL: 72 MONTHS

ADDITIONAL_EXTRAMURAL: YES

WHICH_ADDITIONAL_EXTRAMURAL:WATCHING MOVIES, LISTENING TO MUSIC AND READING

BILINGUAL_PROGRAM: YES

WHEN_BILINGUAL_PROGRAM: 2007

BILINGUAL_SUBJECTS: CMC, INTEGRATED PROJECT

BILINGUAL_EXTRA_HOURS_SUBJECTS: 4

COMPOSITION:

One day, a boy was in his bedroom with his frog and his dog. The frog was inside of a vase, and when the boy went to sleep the frog escaped from the vase. The next day, the boy saw that the frog wasn't there, so he and his dog went to look for the frog to the forest. The boy was shouting and looking for the frog in trees, behind the branches but suddenly a dder took the boy and pushed him to the river and the falled. In the river he hold a trunk and finally behind the trunk, was the frog. The frog was with his family but the boy took his frog and waved goodbye.

FILE_NAME: B2_2BAC_17_CAR_ADD_DNR

LEVEL: B2

INITIALS:DNR

NICK: DEBO

AGE:17

SEX:FEMALE

COURSE: 2BAC

SCHOOL: CARTUJA

L1: SPANISH

FATHERS_L1: SPANISH

MOTHERS_L2: SPANISH

LANGUAGE_AT_HOME: SPANISH

AGE_EXPOSURE: 10

SPEAKING_SELF:B1

LISTENING_SELF: B1

READING_SELF:B1

WRITING_SELF: B2

OTHER_LANGUAGE: YES

WHICH_LANG: FRENCH 
ENGLISH_MARK_LAST_YEAR:8

STAY_ABROAD: NO

WHERE_STAY?:

WHEN_STAY?:

MONTHS_STAY: 10 DAYS

EXTRAMURAL_INSTRUCTION: YES

WHEN_EXTRAMURAL: TWICE A WEEK

MONTHS_EXTRAMURAL: 2 YEARS

ADDITIONAL_EXTRAMURAL: NO

WHICH_ADDITIONAL_EXTRAMURAL:

BILINGUAL_PROGRAM: NO

WHEN_BILINGUAL_PROGRAM:

BILINGUAL_SUBJECTS:

BILINGUAL_EXTRA_HOURS_SUBJECTS:

COMPOSITION:

One day, a boy found a frog and in the night he put/ left on the vase and in the floor, when he is going to sleep, the frog escaped. On the morning the boy awake and how he was worried, he decided look for to the frog. He was with his dog. In the forest, he was shouting, althought the dog shake the \$_UNR_i \$_INS_branch \$_INS_and the bee drop but the boy was, un in the brach of a tree and he look out on the trunk. \$_UNR_ $i$ the boy that he was in the rock, he hold in the brach i, but it didn't be a brach, because it was a deer. The deer pushed \$_UNR_i the boy and the dog, and the two fall in the water in \$_UNR_i other trunk looked at down and he found a family of frogs. He found his frog, and his hand \$_INS_and he \$_UNR_i \$_UNR_i \$_UNR_i goodbye at the family of frogs.

FILE_NAME: B2_2BAC_18_CAR_ADD_ALF

LEVEL: B2

INITIALS:ALF

NICK: ANDREA

AGE:18

SEX:FEMALE

COURSE: 2BAC

SCHOOL: CARTUJA

L1: SPANISH

FATHERS_L1: SPANISH

MOTHERS_L2: SPANISH

LANGUAGE_AT_HOME: SPANISH 


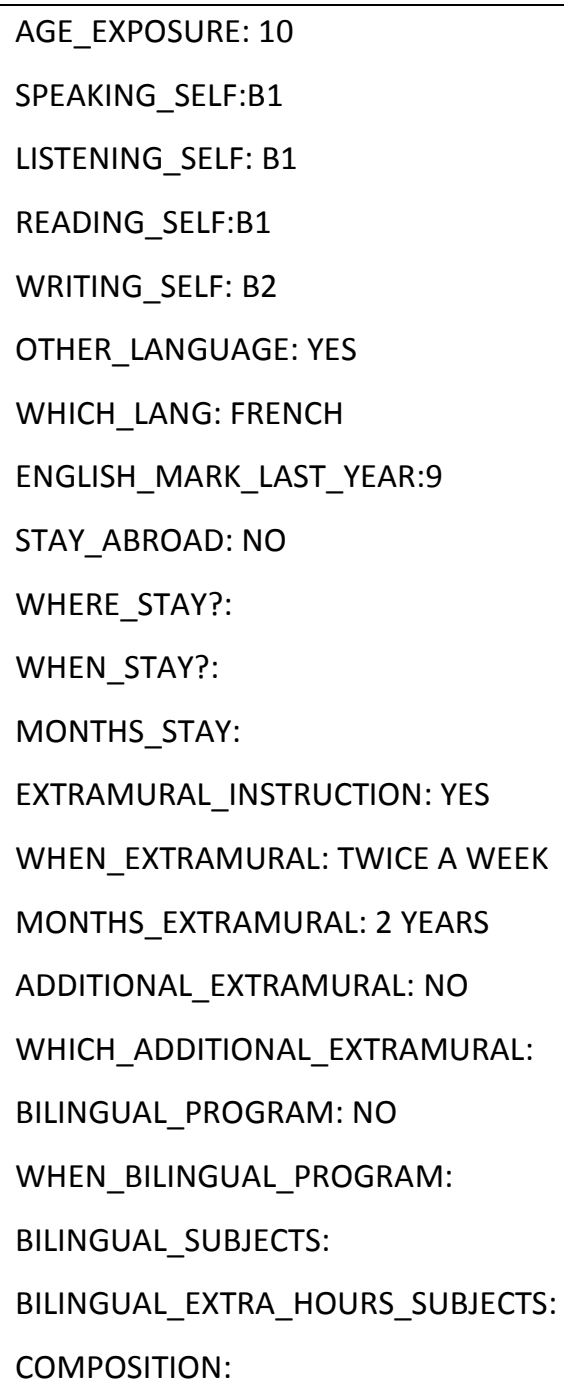

One day, a boy had a dog and a frog. The boy kept the frog in a vase. Onenight when he was sleeping, the frog jumped out of the vase to the floor and she left out of the room. The next morning, when the boy got up \$_INS_he looked to the vase, and he saw that his frog weren't here! the boy, worried went to the forest with his dog for looking for the frog. He shouted, and he \$_INS_was looking for in a branch, in a rock... when a deer pushed him \$_RWU_and \$_RWU_he to a river and the boy \$_INS_and \$_INS_his \$_INS_dog fell to the water. At the water, they held in a broken \$_RWU_branch trunk. They found in the trunk to his frog and his family's frog. They (the boy and his dog) left the \$_INS_family's frog there, and waved goodbye

FILE_NAME: B2_4ESO_15_SCA_ADD_AJS

LEVEL: B2

INITIALS:JRR

NICK: ABEL

AGE:15 
SEX:MALE

COURSE:4ㅌSO

SCHOOL: SANTA CATALINA ALEJANDRÍA

L1: SPANISH

FATHERS_L1: SPANISH

MOTHERS_L2: SPANISH

LANGUAGE_AT_HOME: SPANISH

AGE_EXPOSURE: 9

SPEAKING_SELF:B1

LISTENING_SELF: B1

READING_SELF:B1

WRITING_SELF: B1

OTHER_LANGUAGE: YES

WHICH_LANG: FRENCH

ENGLISH_MARK_LAST_YEAR:9

STAY_ABROAD: YES

WHERE_STAY?: ENGLAND

WHEN_STAY?: 2011

MONTHS_STAY: 10 DAYS

EXTRAMURAL_INSTRUCTION: NO

WHEN_EXTRAMURAL:

MONTHS_EXTRAMURAL:

ADDITIONAL_EXTRAMURAL: NO

WHICH_ADDITIONAL_EXTRAMURAL:

BILINGUAL_PROGRAM: YES

WHEN_BILINGUAL_PROGRAM: 2010

BILINGUAL_SUBJECTS: SOCIAL SCIENCES, MATHEMATICS, PHYSICS AND CHEMISTRY

BILINGUAL_EXTRA_HOURS_SUBJECTS: AROUND 7

COMPOSITION:

One day, one boy and his dog were sitting watching a frog together. The boy went to the bed, while he was sleeping the frog \$_RWU_went \$_RWU_out \$_RWU_of \$_RWU_the escaped of the house. Worried the boy looked for the frog with his dog, they entered in a forest. The boy was looking for the frog in a rock when \$_RWU_the a deer pushed him and throwed him into a river. The boy swam to the shore and he found a group of frogs; his frog was $\$$ _RWU_on with the group. The boy took all the frogs to his house and \$_RWU_them they were very happy all together. 
FILE_NAME: B2_4ESO_15_SCA_ADD_JRR

LEVEL: B2

INITIALS:JRR

NICK: JULIA

AGE:15

SEX:FEMALE

COURSE:4ESO

SCHOOL: SANTA CATALINA ALEJANDRÍA

L1: SPANISH

FATHERS_L1: SPANISH

MOTHERS_L2: SPANISH

LANGUAGE_AT_HOME: SPANISH

AGE_EXPOSURE: 10

SPEAKING_SELF:B2

LISTENING_SELF: B2

READING_SELF:B2

WRITING_SELF: B2

OTHER_LANGUAGE: YES

WHICH_LANG: FRENCH AND GERMAN

ENGLISH_MARK_LAST_YEAR:10

STAY_ABROAD: NO

WHERE_STAY?:

WHEN_STAY?:

MONTHS_STAY:

EXTRAMURAL_INSTRUCTION:

WHEN_EXTRAMURAL:

MONTHS_EXTRAMURAL:

ADDITIONAL_EXTRAMURAL: YES

WHICH_ADDITIONAL_EXTRAMURAL: READING, LISTENING TO MUSIC

BILINGUAL_PROGRAM: YES

WHEN_BILINGUAL_PROGRAM: 2010

BILINGUAL_SUBJECTS: SOCIAL SCIENCES, MATHEMATICS, PHYSICS AND CHEMISTRY

BILINGUAL_EXTRA_HOURS_SUBJECTS: AROUND 7

COMPOSITION:

One day, a boy found a frog and put it in a vase. He was very happy with his new pet. At night he went to bed. He wanted to played with the frog the following day, but while he was sleeping, the frog escaped from the vase and went out of the house. When the boy woke up and discovered that the frog wasn't 
there, he felt very sad. He decided to look for it, helped by his dog. They went to the forest and shouted and called it, but, it didn't appeared. The boy climbed a tree to look into a whole in the trunk, and climbed a rock too. \$_UNR_¿ But he confused the horns of a deer with some branches. The deer stood up suddenly and \$_RWU_the \$_RWU_boy carried the boy with its horns. Then it threw into the water of a small lake. He went out the water, wet and tired. But when he looked behind a trunk he became very happy. The S_RWU_re frog was there! It was with its family. The frog was happy to see him too, so the boy took it woth him, and they went bak to their house.

FILE_NAME: B2_4ESO_16_SCA_ADD_ALR

LEVEL: B2

INITIALS:ALR

NICK: ARTURO

AGE:16

SEX:MALE

COURSE:4응

SCHOOL: SANTA CATALINA ALEJANDRÍA

L1: SPANISH

FATHERS_L1: SPANISH

MOTHERS_L2: SPANISH

LANGUAGE_AT_HOME: SPANISH

AGE_EXPOSURE: 10

SPEAKING_SELF:B2

LISTENING_SELF: B2

READING_SELF:B2

WRITING_SELF: B2

OTHER_LANGUAGE: YES

WHICH_LANG: FRENCH AND GERMAN

ENGLISH_MARK_LAST_YEAR:10

STAY_ABROAD: YES

WHERE_STAY?: IRELAND

WHEN_STAY?: 2011

MONTHS STAY: 10 DAYS

EXTRAMURAL_INSTRUCTION: YES

WHEN_EXTRAMURAL: SINCE 2010

MONTHS_EXTRAMURAL: AROUND 16 MONTHS

ADDITIONAL_EXTRAMURAL: YES

WHICH_ADDITIONAL_EXTRAMURAL: READING, LISTENING TO MUSIC 


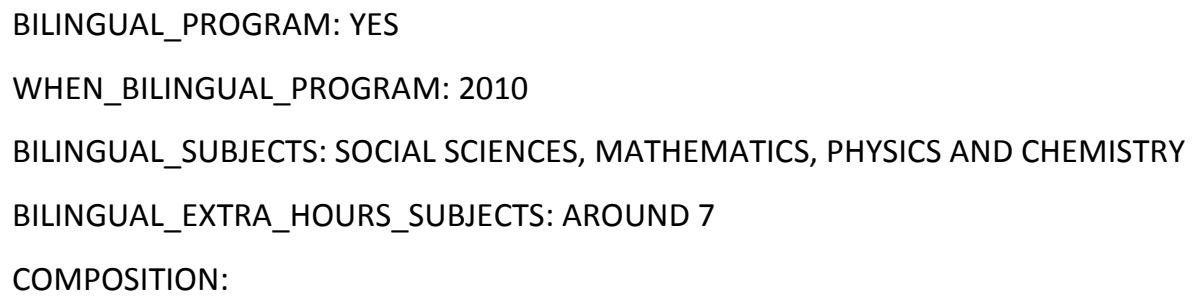

One day, a little boy was sat next to his bed looking to his new pet, a frog. That night he went to sleep vety happy. Next day in the morning when he got up, the vase where the frog was kept was open, and the frog dissapeared. As fast as he could, he went to look for \$_UNR_¿ it because he was very worried. Next to his house there was a forest and the little boy with his dog got into it. He started to shout: FROOOOOG!. Climbing trees and rocks to try find the frog, but it wasn't easy. Suddenly a deer came to him, and push the little boy and the dog into \$_RWU_the a lake. Luckily for them, they found a trunk near them in the water. Quickly go up the trunk. And what a surprise! \$_UNR_¿ A group of frogs were at the back of the trunk. Obviously his frog was too. He took it and wave goodbye to the animals. \$_UNR_i in the end, he returned home with the two pets.

FILE_NAME: C1_1BAC_16_SCA_ADD_CCC

LEVEL: C1

INITIALS:CCC

NICK: CHARO

AGE:16

SEX:MALE

COURSE: 1BACHILLER

SCHOOL: SANTA CATALINA ALEJANDRÍA

L1: SPANISH

FATHERS_L1: SPANISH

MOTHERS_L2: SPANISH

LANGUAGE_AT_HOME: SPANISH

AGE_EXPOSURE: 6

SPEAKING_SELF:B2

LISTENING_SELF: B1

READING_SELF:B2

WRITING_SELF: B1

OTHER_LANGUAGE: YES

WHICH_LANG: FRENCH AND GERMAN

ENGLISH_MARK_LAST_YEAR: 10

STAY_ABROAD: YES 


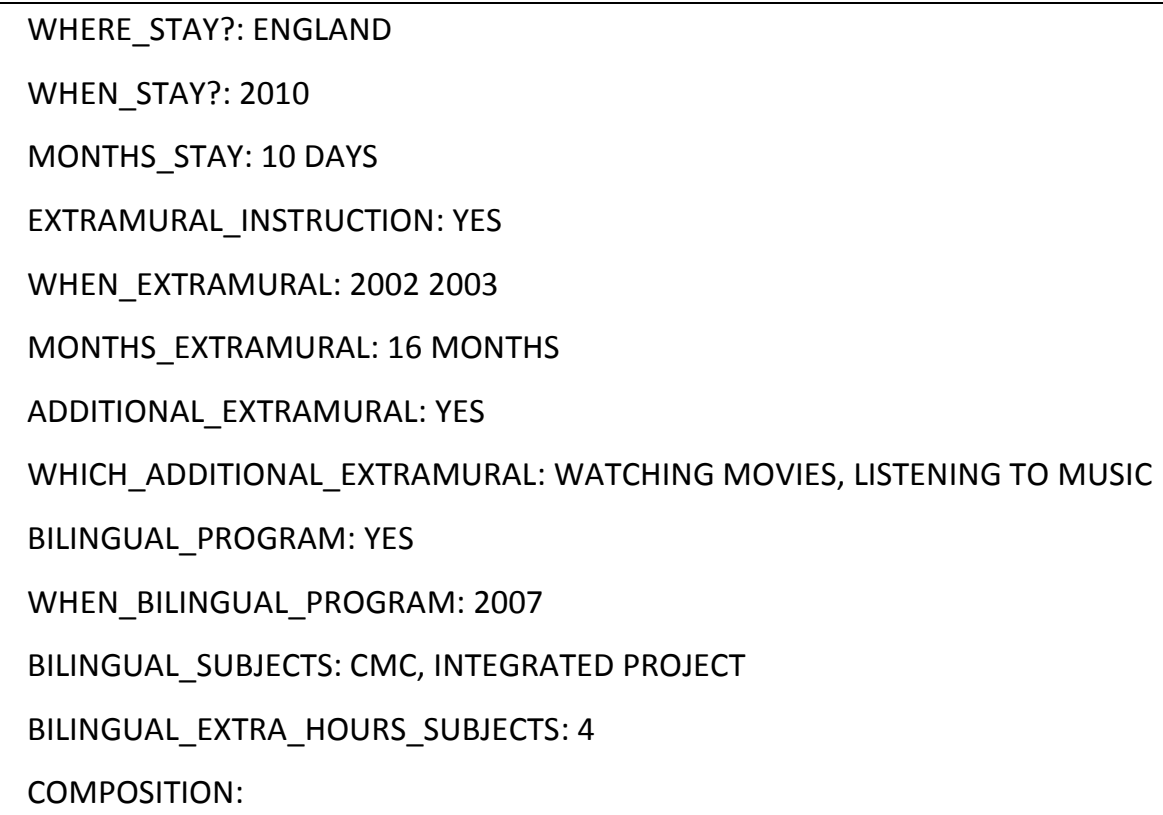

One day, a boy was looking at the frog that his parents had gave him. He \$_RWU_call called the frog Charizar. Charizar felt confortable at its new house, but at night, the frog started to miss its family, so she decided to scape. The next day, when the boy, Ruben Dario woke up, he show the empty glass vase where Charizar should be. He started to felt sad, so \$_RWU_we he went into the forest looking for it and shouting: "Charizar, Charizar, please, come back to your vase; if you don't like it, I will but you a Pokeball but please come back" \$_UNR_¿ While he was looking for the frog, he make a deer to wake up. The deer, Vicente, was very angry and \$_RWU_he \$_RWU_take it took to buy and carried him and push him throught a very high rock. Unfortunately, behind the rock, ther ewas a river, so he felt down into the river. Ruben Dario started to feel afreid because he couldn't swim, and when he wast almost died, Charizar appear and pull him to the sand, where Ruben Dario started to feel better and better. After twenty minutes, the boy \$_RWU_can was able to get up. Charizar spoke him about its family and Ruben Dario decided to leave it in the forest becasue the frog wanted to take care of it \$_UNR_¿ frog-babies.

FILE_NAME: C1_1BAC_16_SCA_ADD_CNL

LEVEL: C1

INITIALS:CNL

NICK: ACHELE

AGE:16

SEX:FEMALE

COURSE: 1BACHILLER

SCHOOL: SANTA CATALINA ALEJANDRÍA

L1: SPANISH

FATHERS_L1: SPANISH 
MOTHERS_L2: SPANISH

LANGUAGE_AT_HOME: SPANISH

AGE_EXPOSURE: 6

SPEAKING_SELF:B2

LISTENING_SELF: B2

READING_SELF:B1

WRITING_SELF: B1

OTHER_LANGUAGE: YES

WHICH_LANG: FRENCH

ENGLISH_MARK_LAST_YEAR: 10

STAY_ABROAD:YES

WHERE_STAY?: ENGLAND

WHEN_STAY?: 2011

MONTHS_STAY: 10 DAYS

EXTRAMURAL_INSTRUCTION: NO

WHEN_EXTRAMURAL:

MONTHS_EXTRAMURAL:

ADDITIONAL_EXTRAMURAL: YES

WHICH_ADDITIONAL_EXTRAMURAL: READING MAGAZINES, WATCHING TV SHOWS, LISTENING TO MUSIC

BILINGUAL_PROGRAM: YES

WHEN_BILINGUAL_PROGRAM: 2007

BILINGUAL_SUBJECTS: CMC, INTEGRATED PROJECT

BILINGUAL_EXTRA_HOURS_SUBJECTS: 4

COMPOSITION:

One day, Luck was in his bedroom, staring at his frog and playing with Arthur, his dog. He wanted to stay awake all night, but he \$_RWU_feel fell asleep. When he woke up in the morning, he noticed that his frog wasn't there. luck lost it and he couldn't aver name her! So he decided to go outside and look for her. Luck went to the forest and AQrthur went with him. He looked everywhere, even inside of every tree he found, but his little frog still missing. While he was trying to find her, he almost stucked in the branch of a tree. Everything seemed to be calmed, but suddenly a big deer came out of nowhere and scared him. Due to this he fell off in the floor. Arthur with him. He started to run because he was afraid of the deer and he didn't notice that he was coming close to the river, and Luck fell into the water, becoming all wet. $\mathrm{He}$ almost lost his hopes on finding the frog, but he realized that next to the river, it was a big tree on the floor and it was full of frogs. He undesrtood that all the frogs were a family and he decided to leave them there to live free and happy. "Sorry for the Disney happy ending, but it wasn't not time to make it better" 
FILE_NAME: C1_1BAC_16_SCA_ADD_LMG

LEVEL: C1

INITIALS:LMG

NICK: LORENA

AGE:16

SEX:FEMALE

COURSE: 1BACHILLER

SCHOOL: SANTA CATALINA ALEJANDRÍA

L1: SPANISH

FATHERS_L1: SPANISH

MOTHERS_L2: SPANISH

LANGUAGE_AT_HOME: SPANISH

AGE_EXPOSURE: 5

SPEAKING_SELF:B1

LISTENING_SELF: B1

READING_SELF:B1

WRITING_SELF: B1

OTHER_LANGUAGE: YES

WHICH_LANG: FRENCH

ENGLISH_MARK_LAST_YEAR: 10

STAY_ABROAD: YES

WHERE_STAY?: ENGLAND

WHEN_STAY?: 2010

MONTHS_STAY: 10 DAYS

EXTRAMURAL_INSTRUCTION: NO

WHEN_EXTRAMURAL:

MONTHS_EXTRAMURAL:

ADDITIONAL_EXTRAMURAL: YES

WHICH_ADDITIONAL_EXTRAMURAL: WATCHING MOVIES, LISTENING TO MUSIC

BILINGUAL_PROGRAM: YES

WHEN_BILINGUAL_PROGRAM: 2007

BILINGUAL_SUBJECTS: CMC, INTEGRATED PROJECT

BILINGUAL_EXTRA_HOURS_SUBJECTS: 4

COMPOSITION:

One day, a boy called Dougie, was in his bedroom watching the frog that his parents gave him for his birthday. This dog (Kitty) like \$_Ins_liked the smell of the frog so she started to smeel it. That night, while 
Dougie was asleep the \$_RWU_dog frog \$_RWU_disapeared escaped from the bottle where she was. The next day, Dougie started to look for rhe little frog in the forest. He shouted and shouted the name of the frog (Delsie) but she didn't appeared. He looked of the frog inside the tree but she wasn't there. While Dougie was looking for the frog some bees bit Kitty, but \$_RWU_in a few months she_ she didn't it suffer any damage. Dougie continued looking for \$_RWU_thefrog frog, and while he was shouting again a deer appeared! S_RWU_it held the deer held kitty and throved into the river too! \$_RWU_while after getting out of the river, they looked behind a trunk and ther she was!lt was Delsie and she was visiting her familiy. Then Dougie told Delsie that him and Kitty were upset becasue the missed her a lot, so Delsie came home again with Dougie and Kitty.

FILE_NAME: C1_1BAC_17_SCA_ADD_AAO

LEVEL: C1

INITIALS:AAO

NICK: DAWI

AGE:17

SEX:FEMALE

COURSE: 1으ACHILLER

SCHOOL: SANTA CATALINA ALEJANDRÍA

L1: SPANISH

FATHERS_L1: SPANISH

MOTHERS_L2: SPANISH

LANGUAGE_AT_HOME: SPANISH

AGE_EXPOSURE: 6

SPEAKING_SELF:B1

LISTENING_SELF: B1

READING_SELF:B2

WRITING_SELF: B1

OTHER_LANGUAGE: YES

WHICH_LANG: FRENCH AND GERMAN

ENGLISH_MARK_LAST_YEAR: 9

STAY_ABROAD: NO

WHERE_STAY?:

WHEN_STAY?:

MONTHS_STAY:

EXTRAMURAL_INSTRUCTION: NO

WHEN_EXTRAMURAL:

MONTHS_EXTRAMURAL: 


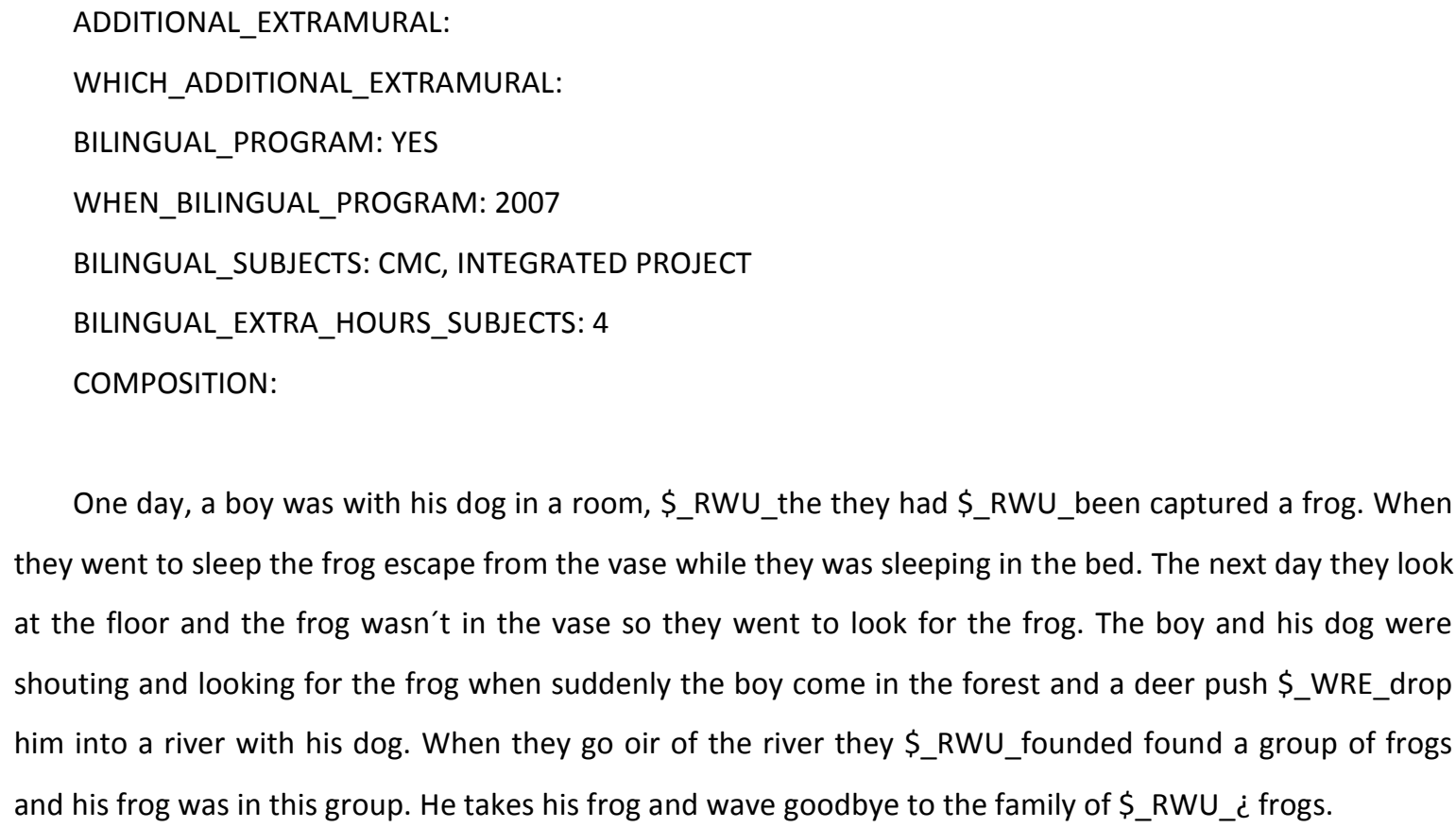

One day, a boy was with his dog in a room, \$_RWU_the they had \$_RWU_been captured a frog. When they went to sleep the frog escape from the vase while they was sleeping in the bed. The next day they look at the floor and the frog wasn't in the vase so they went to look for the frog. The boy and his dog were shouting and looking for the frog when suddenly the boy come in the forest and a deer push \$_WRE_drop him into a river with his dog. When they go oir of the river they \$_RWU_founded found a group of frogs and his frog was in this group. He takes his frog and wave goodbye to the family of \$_RWU_i frogs.

FILE_NAME: C1_1BAC_17_SCA_ADD_CCG

LEVEL: C1

INITIALS:CCG

NICK: CRISTINA

AGE:17

SEX:FEMALE

COURSE: 1ㅇACHILLER

SCHOOL: SANTA CATALINA ALEJANDRÍA

L1: SPANISH

FATHERS_L1: SPANISH

MOTHERS_L2: SPANISH

LANGUAGE_AT_HOME: SPANISH

AGE_EXPOSURE: 8

SPEAKING_SELF:B2

LISTENING_SELF: B1

READING_SELF:B1

WRITING_SELF: B1

OTHER_LANGUAGE: YES

WHICH_LANG: FRENCH AND GERMAN

ENGLISH_MARK_LAST_YEAR: 10

STAY_ABROAD: YES

WHERE_STAY?: ENGLAND 
WHEN_STAY?: 2010

MONTHS_STAY: 10 DAYS

EXTRAMURAL_INSTRUCTION: NO

WHEN_EXTRAMURAL:

MONTHS_EXTRAMURAL:

ADDITIONAL_EXTRAMURAL: YES

WHICH_ADDITIONAL_EXTRAMURAL: READING MAGAZINES, WATCHING TV SHOWS, LISTENING TO MUSIC

BILINGUAL_PROGRAM: YES

WHEN_BILINGUAL_PROGRAM: 2007

BILINGUAL_SUBJECTS: CMC, INTEGRATED PROJECT

BILINGUAL_EXTRA_HOURS_SUBJECTS: 4

COMPOSITION:

One day, a happy boy called Peter caught a frog, a green and jumpy frog. He was helped by his friendly dog, Pooppi, because the frog always \$_RWU_wanter tried to escape. Peter left the frog into the vase, becasue it's transparent, so he could always look how his frog was or what \$_RWU_was it doing. It was doing. Suddenly, the frog went out of the big \$_RWU_glass glass for having fun outside. The next mornig, Peter realised it wasn't there, and worried decided to look for it with Poppi. \$_RWU_c Peter \$_RWU_screamed shouted Frog!frog, where are you? Pooppi and i want you to come back home! But the frog didn't appear. They kept on searching it, around the trees behind the rocks... but nothing at all. While Peter and Pooppi were looking for the small animal, something touched and caught the boy. Peter, terrified didn't know what was happening when he felt down into the water... The cold waters of the small lake of the forest where they were carried them \$_RWU_noises that sounded_boy and his dog followed the noises until the found a dead trunk. The noise was stonger. When they looked behind it... surprise! The frog was there with its family and friends! Happily. Peter and Pooppie came back with their green friend and the \$_RWU.¿ं story's got an awesome ending.

FILE_NAME: C1_1BAC_17_SCA_ADD_JLR

LEVEL: C1

INITIALS: JLR

NICK: JAVIER LIEBANA

AGE:17

SEX:MALE

COURSE: 19BACHILLER

SCHOOL: SANTA CATALINA ALEJANDRÍA

L1: SPANISH 


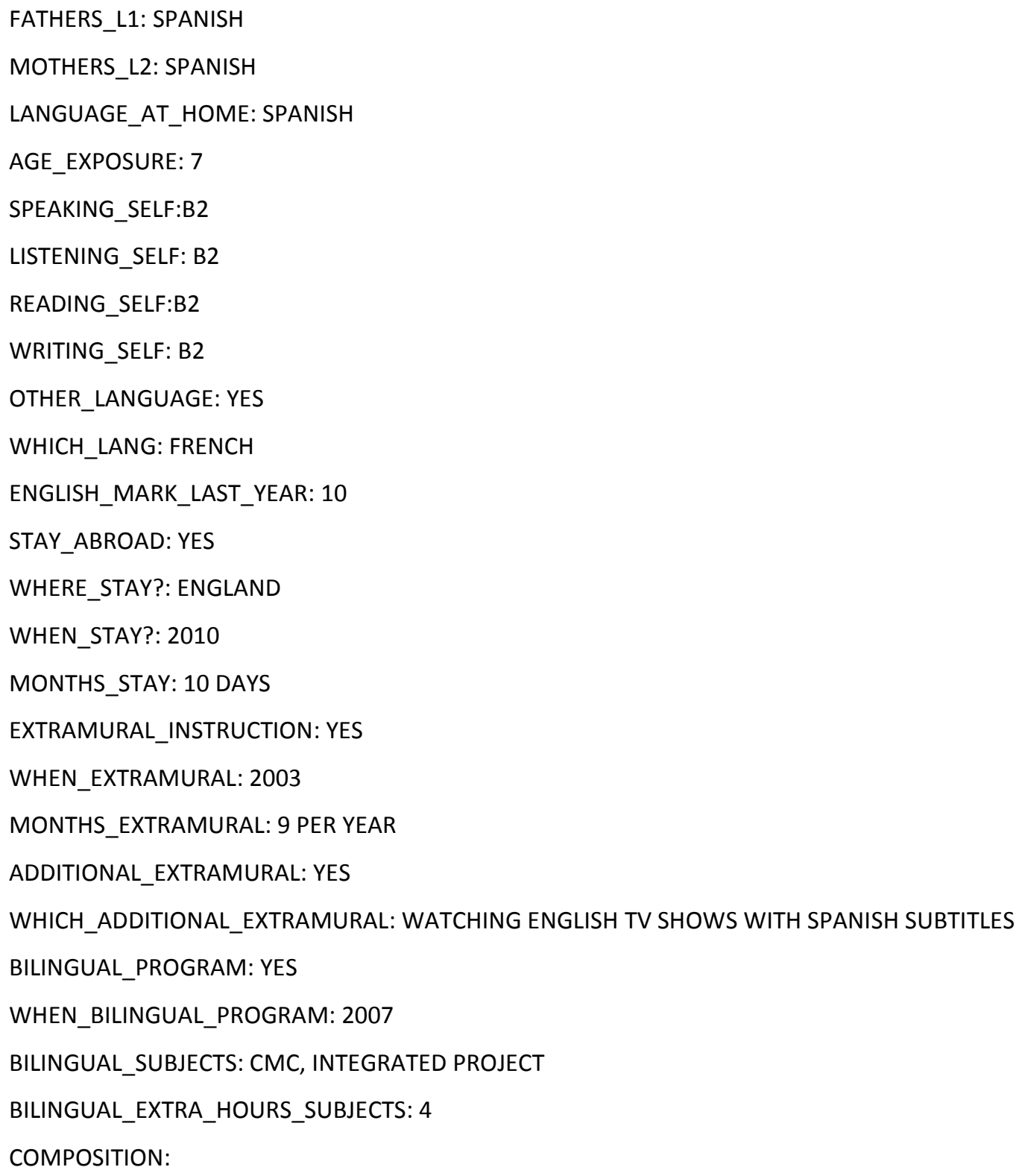

One day, a boy called John bought a frog. \$_RWU_¿ When he brought it home, Jimmy a dog \$_RWU_¿ that was his other pet was curious about the frog, he smelled it and looked at it for a long time. As any other day John went to the bed early. The day after when John woke up, the first thing he did was to look at his frig but... it wasn't \$_RWU_he there! Rapidly John \$_UNR_¿ went with Jimmy to the forest in order to find the frog. They searched everywwhere, inside the bushes, behind the rocks, inside a tree... Suddenly he was over a deer's horns \$_RWU_he \$_RWU_it \$_RWU_was \$_RWU_sleeping \$_RWU_between \$_RWU_the \$_RWU_bushes \$_RWU_c and the deer started to \$_UNR_i run after some minutes the deer stopped \$_UNR_leaving it lefting the child to fall into the river. He was wet and angry, \$_UNR_¿ Jimmy started to bark and John realised that his frog was there. he realised also that the frog was \$_UNR_¿ with his family and since that day John carry the frog there to allow him to be with his family. 
FILE_NAME: C1_1BAC_17_SCA_ADD_LCQ

LEVEL: C1

INITIALS:LCQ

NICK:Luís Laura Crespo

AGE:17

SEX:FEMALE

COURSE: 1BACHILLER

SCHOOL: SANTA CATALINA ALEJANDRÍA

L1: SPANISH

FATHERS_L1: SPANISH

MOTHERS_L2: SPANISH

LANGUAGE_AT_HOME: SPANISH

AGE_EXPOSURE: 10

SPEAKING_SELF:B1

LISTENING_SELF: B1

READING_SELF:B1

WRITING_SELF: B1

OTHER_LANGUAGE: YES

WHICH_LANG: FRENCH

ENGLISH_MARK_LAST_YEAR:10

STAY_ABROAD: YES

WHERE_STAY?: ENGLAND

WHEN_STAY?: 2010

MONTHS_STAY: 10 DAYS

EXTRAMURAL_INSTRUCTION: YES

WHEN_EXTRAMURAL: 12 TIMES PER MONTH

MONTHS_EXTRAMURAL: 72 MONTHS

ADDITIONAL_EXTRAMURAL: YES

WHICH_ADDITIONAL_EXTRAMURAL:WATCHING MOVIES, LISTENING TO MUSIC AND READING

BILINGUAL_PROGRAM: YES

WHEN_BILINGUAL_PROGRAM: 2007

BILINGUAL_SUBJECTS: CMC, INTEGRATED PROJECT

BILINGUAL_EXTRA_HOURS_SUBJECTS: 4

COMPOSITION:

One day, a boy \$_Ins_called TJ, and his dog found a frog and \$_Ins_decided to \$_RWU_looked look after \$_Ins_it \$_RWU_her. They spent days looking at the frog, \$_RWU_and but one night, while TJ and his dig were sleeping, the frog went our the vase and it escaped. The next morning, when they woke up, they 
realized the frog was not there, so \$_RWU_they TJ decided to look for it. First, they went to the forest and there \$_RWU_she he tried to find the frog shouting, but he found nothing. Second, TJ and his dog looked for it in a rock zone. TJ went up \$_RWU_in on a rock and he continued shouting but, again he didn't find anything. While doing this suddently a wild deer appeared and rapidly pushed it TJ.

TJ and his dog fell down on a river and got wet and dizzy. The boy could reach a trunk and held it. Due to the falling, they \$_RWU_could fould the frog with its family. After \$_RWU_c that, he waved goodbye and went home again. Finally, he realised that if he hadn't fallen, he wouldn't have found his frog. 
Morpheme tagging scheme for Past regular

\begin{tabular}{|c|c|c|c|}
\hline \multicolumn{3}{|c|}{ OC: Past reg (Peter walked yesterday) } & S: Supplied form \\
\hline \multicolumn{2}{|c|}{$\begin{array}{l}\text { Target-like Use } \\
\text { (correct form supplied) }\end{array}$} & & Peter walked yesterday \\
\hline \multirow[t]{3}{*}{$\begin{array}{l}\text { Non-target- } \\
\text { like Use }\end{array}$} & Underuse & & Peter walk_ _ yesterday \\
\hline & \multirow[t]{2}{*}{ Misuse } & $\begin{array}{l}\text { Misselection } \\
\text { (form exists) }\end{array}$ & Peter walking yesterday \\
\hline & & $\begin{array}{l}\text { Misrealisation } \\
\text { (form does not } \\
\text { exist) }\end{array}$ & $\mathrm{n} / \mathrm{a}$ \\
\hline \multicolumn{3}{|c|}{ OC: ing (Peter is walked [=walking]) } & SNOC \\
\hline & & $\begin{array}{l}\text { Overuse } \\
\quad \text { (correct form } \\
\text { supplied but in } \\
\text { NOC) }\end{array}$ & Peter is walked \\
\hline
\end{tabular}


Morpheme tagging scheme for Past regular

\begin{tabular}{|c|c|c|c|}
\hline \multicolumn{3}{|c|}{ OC: Past reg (Peter walked yesterday) } & S: Supplied form \\
\hline \multicolumn{2}{|c|}{$\begin{array}{l}\text { Target-like Use } \\
\text { (correct form supplied) }\end{array}$} & & Peter walked yesterday \\
\hline \multirow[t]{3}{*}{$\begin{array}{l}\text { Non-target- } \\
\text { like Use }\end{array}$} & Underus & & Peter walk__yesterday \\
\hline & \multirow[t]{2}{*}{ Misuse } & $\begin{array}{l}\text { Misselection } \\
\text { (form exists) }\end{array}$ & Peter walking yesterday \\
\hline & & $\begin{array}{l}\text { Misrealisation } \\
\text { (form does not } \\
\text { exist) }\end{array}$ & $\mathrm{n} / \mathrm{a}$ \\
\hline \multicolumn{3}{|c|}{ OC: ing (Peter is walked [=walking]) } & SNOC \\
\hline & & $\begin{array}{l}\text { Overuse } \\
\quad \text { (correct form } \\
\text { supplied but in } \\
\text { NOC) }\end{array}$ & Peter is walked \\
\hline
\end{tabular}


Morpheme tagging scheme for Past Irregular

\begin{tabular}{|c|c|c|c|}
\hline \multicolumn{3}{|c|}{ OC: Past irreg (Peter stole yesterday) } & S: Supplied form \\
\hline \multicolumn{2}{|c|}{$\begin{array}{l}\text { Target-like Use } \\
\text { (correct form supplied) }\end{array}$} & & Peter stole yesterday \\
\hline \multirow[t]{4}{*}{$\begin{array}{l}\text { Non-target- } \\
\text { like Use }\end{array}$} & $\begin{array}{r}\text { Underuse } \\
\text { (no form } \\
\text { supplied) }\end{array}$ & & Peter steal__ yesterday \\
\hline & \multirow{3}{*}{$\begin{array}{l}\text { Misuse } \\
\text { (incorrect } \\
\text { form } \\
\text { supplied) }\end{array}$} & $\begin{array}{l}\text { Misselection } \\
\text { (form exists) }\end{array}$ & Peter stealing yesterday \\
\hline & & \multirow[t]{2}{*}{$\begin{array}{l}\text { Misrealisation } \\
\text { (form does not } \\
\text { exist) }\end{array}$} & Peter stealed yesterday \\
\hline & & & Peter stoled yesterday \\
\hline \multicolumn{3}{|c|}{ OC: $3^{\text {rd }}$ sing (Peter never stole [=steals] } & SNOC \\
\hline & & $\begin{array}{l}\text { Overuse } \\
\text { (correct form } \\
\text { supplied but in } \\
\text { NOC) }\end{array}$ & Peter never stole \\
\hline
\end{tabular}


Morpheme tagging scheme for Third person singular -s

\begin{tabular}{|c|c|c|c|}
\hline \multicolumn{3}{|c|}{$\begin{array}{l}\text { OC: } 3^{\text {rd }} \text { sing (He has a friend) / (He never eats } \\
\text { pasta) }\end{array}$} & S: Supplied form \\
\hline \multicolumn{2}{|c|}{$\begin{array}{l}\text { Target-like Use } \\
\text { (correct form supplied) }\end{array}$} & & He has a friend / He never eats \\
\hline \multirow[t]{3}{*}{$\begin{array}{l}\text { Non-target- } \\
\text { like Use }\end{array}$} & $\begin{array}{l}\text { Underuse } \\
\text { (no form } \\
\text { supplied) }\end{array}$ & & He have_ a friend / He never eat \\
\hline & \multirow{2}{*}{$\begin{array}{l}\text { Misuse } \\
\text { (incorrect } \\
\text { form } \\
\text { supplied) }\end{array}$} & $\begin{array}{l}\text { Misselection } \\
\text { (form exists) }\end{array}$ & He had a friend / He never eating \\
\hline & & $\begin{array}{l}\text { Misrealisation } \\
\text { (form does not } \\
\text { exist) }\end{array}$ & \\
\hline \multicolumn{3}{|c|}{$\begin{array}{l}\text { OC: Past irreg (He has a problem [=had] } \\
\text { yesterday) }\end{array}$} & SNOC \\
\hline & & $\begin{array}{l}\text { Overuse } \\
\quad \text { (correct form } \\
\text { supplied but in } \\
\text { NOC) }\end{array}$ & He has a problem yesterday \\
\hline
\end{tabular}


Morpheme tagging scheme for Present progressive -ing

\begin{tabular}{|c|c|c|c|}
\hline \multicolumn{3}{|c|}{ OC: Progressive (Peter is swimming) } & S: Supplied form \\
\hline \multicolumn{2}{|c|}{$\begin{array}{l}\text { Target-like Use } \\
\text { (correct form supplied) }\end{array}$} & & Peter is swimming \\
\hline \multirow[t]{3}{*}{$\begin{array}{l}\text { Non-target- } \\
\text { like Use }\end{array}$} & $\begin{array}{l}\text { Underuse } \\
\text { (no form } \\
\text { supplied) }\end{array}$ & & Peter is swim \\
\hline & \multirow{2}{*}{$\begin{array}{l}\text { Misuse } \\
\text { (incorrect } \\
\text { form } \\
\text { supplied) }\end{array}$} & $\begin{array}{l}\text { Misselection } \\
\text { (form exists) }\end{array}$ & Peter is swims \\
\hline & & $\begin{array}{l}\text { Misrealisation } \\
\text { (form does not } \\
\text { exist) }\end{array}$ & n.a. \\
\hline \multicolumn{3}{|c|}{ OC: $3^{\text {rd }}$ sing (Peter swimming [ $=$ swims] every day) } & SNOC \\
\hline & & $\begin{array}{l}\text { Overuse } \\
\quad \text { (correct form } \\
\text { supplied but in } \\
\text { NOC) }\end{array}$ & swimming \\
\hline
\end{tabular}


Morpheme tagging scheme for Copula Be

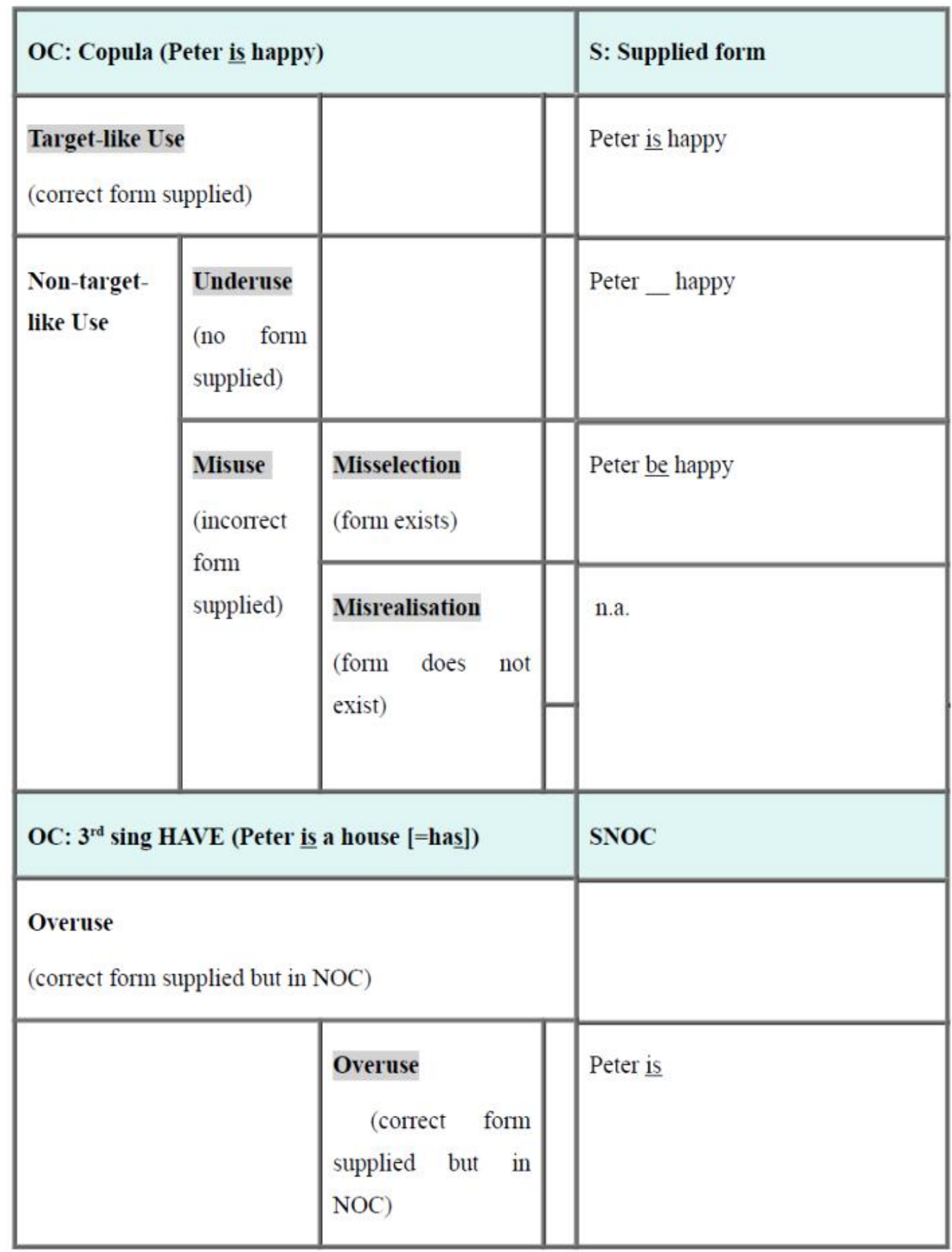


Morpheme tagging scheme for Auxiliar Be

\begin{tabular}{|c|c|c|c|}
\hline \multicolumn{3}{|c|}{ OC: Aux BE (Peter $\underline{\text { s }}$ swimming) } & S: Supplied form \\
\hline \multicolumn{3}{|c|}{$\begin{array}{l}\text { Target-like Use } \\
\text { (correct form supplied) }\end{array}$} & Peter $\underline{\text { is swimming }}$ \\
\hline \multirow[t]{3}{*}{$\begin{array}{l}\text { Non-target- } \\
\text { like Use }\end{array}$} & $\begin{array}{l}\text { Underuse } \\
\text { (no form } \\
\text { supplied) }\end{array}$ & & Peter__ swimming \\
\hline & \multirow[t]{2}{*}{$\begin{array}{l}\text { Misuse } \\
\text { (incorrect } \\
\text { form } \\
\text { supplied) }\end{array}$} & $\begin{array}{l}\text { Misselection } \\
\text { (form exists) }\end{array}$ & Peter be swimming \\
\hline & & $\begin{array}{l}\text { Misrealisation } \\
\text { (form does not } \\
\text { exist) }\end{array}$ & n.a. \\
\hline \multicolumn{3}{|c|}{ OC: aux HAVE (Peter is left [=has]) } & SNOC \\
\hline & & $\begin{array}{l}\text { Overuse } \\
\quad \quad \text { (correct form } \\
\text { supplied but in } \\
\text { NOC) }\end{array}$ & Peter is left \\
\hline
\end{tabular}


Morpheme tagging scheme for Indefinite article

\begin{tabular}{|c|c|c|c|}
\hline \multicolumn{3}{|c|}{ OC: Indefinite article ( $\mathrm{A}$ friend of mine came) } & S: Supplied form \\
\hline \multicolumn{2}{|c|}{$\begin{array}{l}\text { Target-like Use } \\
\text { (correct form supplied) }\end{array}$} & & $\underline{\mathrm{A}}$ friend of mine \\
\hline \multirow[t]{4}{*}{$\begin{array}{l}\text { Non-target- } \\
\text { like Use }\end{array}$} & $\begin{array}{l}\text { Underuse } \\
\text { (no form } \\
\text { supplied) }\end{array}$ & & _ friend of mine \\
\hline & \multirow{3}{*}{$\begin{array}{l}\text { Misuse } \\
\text { (incorrect } \\
\text { form } \\
\text { supplied) }\end{array}$} & $\begin{array}{l}\text { Misselection } \\
\text { (form exists) }\end{array}$ & $\underline{\text { The friend of mine }}$ \\
\hline & & \multirow{2}{*}{$\begin{array}{l}\text { Misrealisation } \\
\text { (form does not } \\
\text { exist) }\end{array}$} & \\
\hline & & & \\
\hline \multicolumn{3}{|c|}{ OC: generic (I like a pasta [Ø]) } & SNOC \\
\hline & & $\begin{array}{l}\text { Overuse } \\
\quad \text { (correct form } \\
\text { supplied but in } \\
\text { NOC) }\end{array}$ & I like a pasta \\
\hline
\end{tabular}


Morpheme tagging scheme for Possessive -s

\begin{tabular}{|c|c|c|c|}
\hline \multicolumn{3}{|c|}{ OC: Possessive (My mum's car) } & S: Supplied form \\
\hline \multicolumn{2}{|c|}{$\begin{array}{l}\text { Target-like Use } \\
\text { (correct form supplied) }\end{array}$} & & mum's car \\
\hline \multirow[t]{3}{*}{$\begin{array}{l}\text { Non-target- } \\
\text { like Use }\end{array}$} & $\begin{array}{l}\text { Underuse } \\
\text { (no form } \\
\text { supplied) }\end{array}$ & & mum_car \\
\hline & \multirow{2}{*}{$\begin{array}{l}\text { Misuse } \\
\text { (incorrect } \\
\text { form } \\
\text { supplied) }\end{array}$} & $\begin{array}{l}\text { Misselection } \\
\text { (form exists) }\end{array}$ & mums car \\
\hline & & $\begin{array}{l}\text { Misrealisation } \\
\text { (form does not } \\
\text { exist) }\end{array}$ & n.a. \\
\hline \multicolumn{3}{|c|}{ OC: Plural (Kid's like toys [=Kids like toys]) } & SNOC \\
\hline & & $\begin{array}{l}\text { Overuse } \\
\quad \text { (correct form } \\
\text { supplied but in } \\
\text { NOC) }\end{array}$ & Kid's like toys \\
\hline
\end{tabular}


Rewriting unreadable: [the student edits by rewriting; the original formulation is illegible]

Examples :

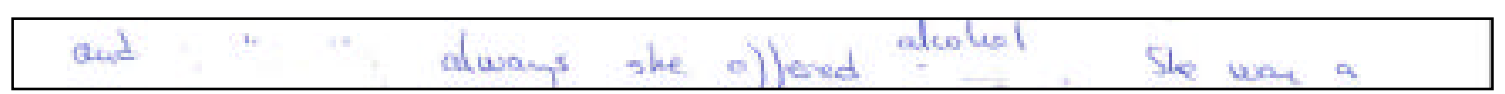

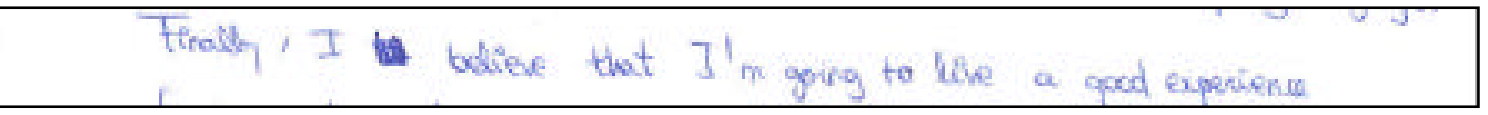

[...] and \$_RWU_i always she offered \$_RWU_i alcohol.

Finally, I \$_RWU_i believe that I'm going to live a good experience $[\ldots]$

\$_RWU_i rewriting unreadable

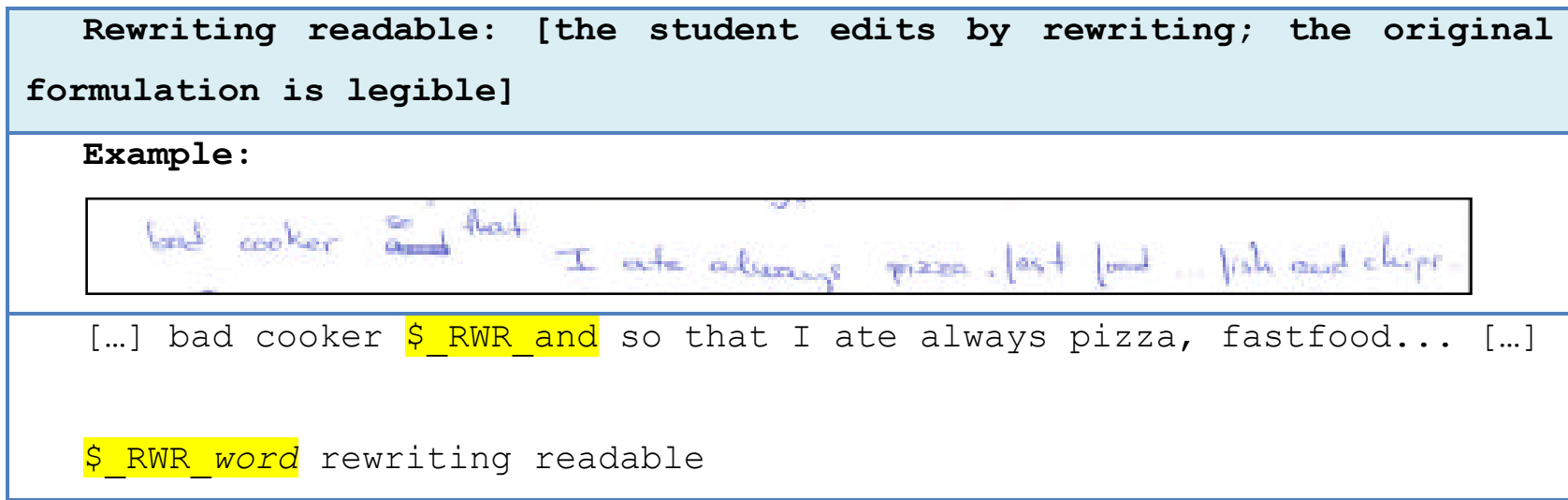

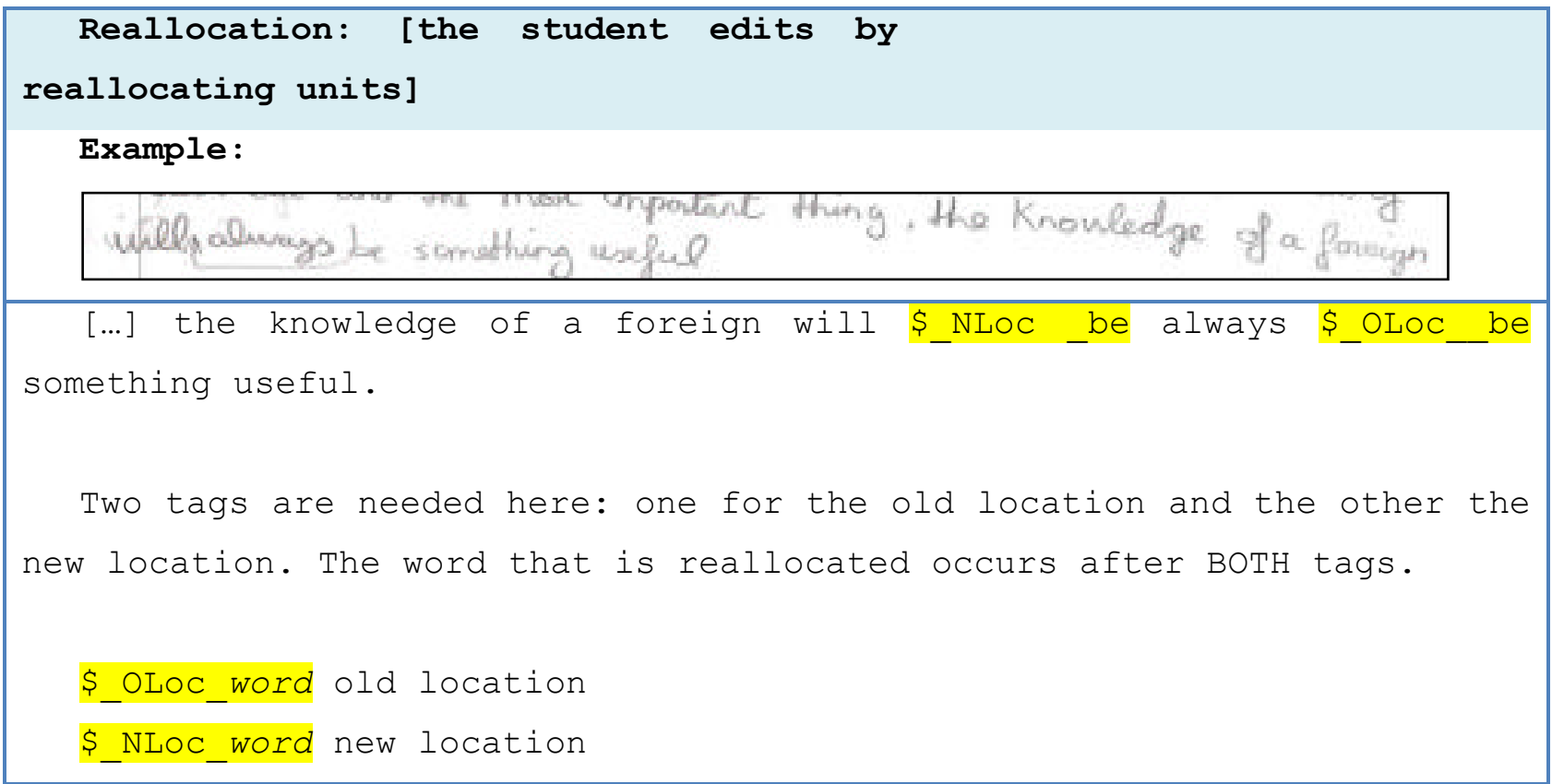




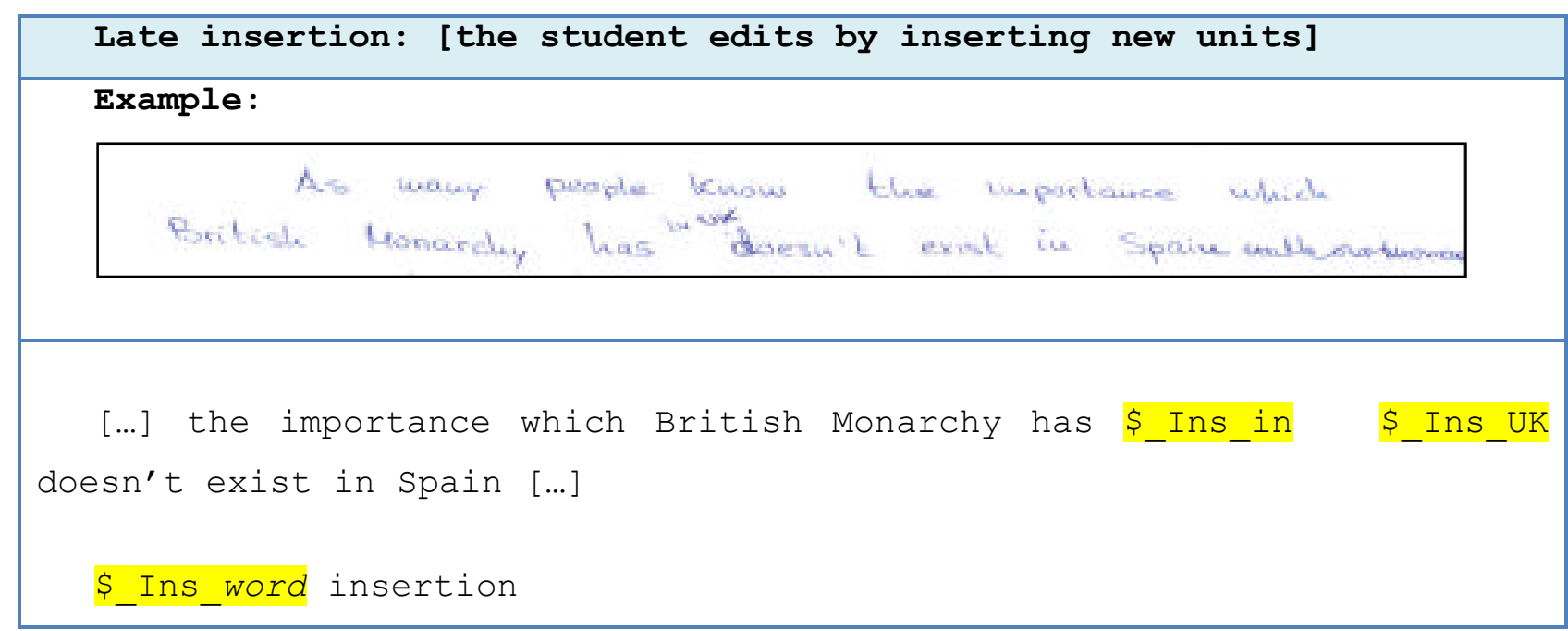

\begin{tabular}{|l|}
\hline [the student's writing is unintelligible] \\
\hline Example: \\
\hline \$_UNR_i unreadable
\end{tabular}


WHEN_EXTRAMURAL: NO

MONTHS_EXTRAMURAL: NO

ADDITIONAL_EXTRAMURAL: YES

WHICH_ADDITIONAL_EXTRAMURAL: READING SCIENTIFIC ARTICLES

BILINGÜAL_PROGRAM Y YES

WHEN_BILINGUAL_PROGRAM: 2010

BILINGUAL_SUBJECTS: SOCIAL SCIENCES, MATHS

BILINGUAL_EXTRA_HOURS_SUBJECTS: 6

COMPOSITION: A boy called Charles was in his bedroom with his pets: a dog $\mathrm{c}$ was sleeping when his frog escaped from its glass. The next day, Charles \& his worried. They went to the forest to search it very quickly. Firstly, they saw in a tree searched behind a rock but it wasn't there. There, there was an enormous beer th Afterwards, they left from the water and they saw a trunk on the land. Behind it, th the three arrived home very happy. Charles never forget this accident and now he $<<<>>$ Ignore Delete Other Action... Save Close Help VC

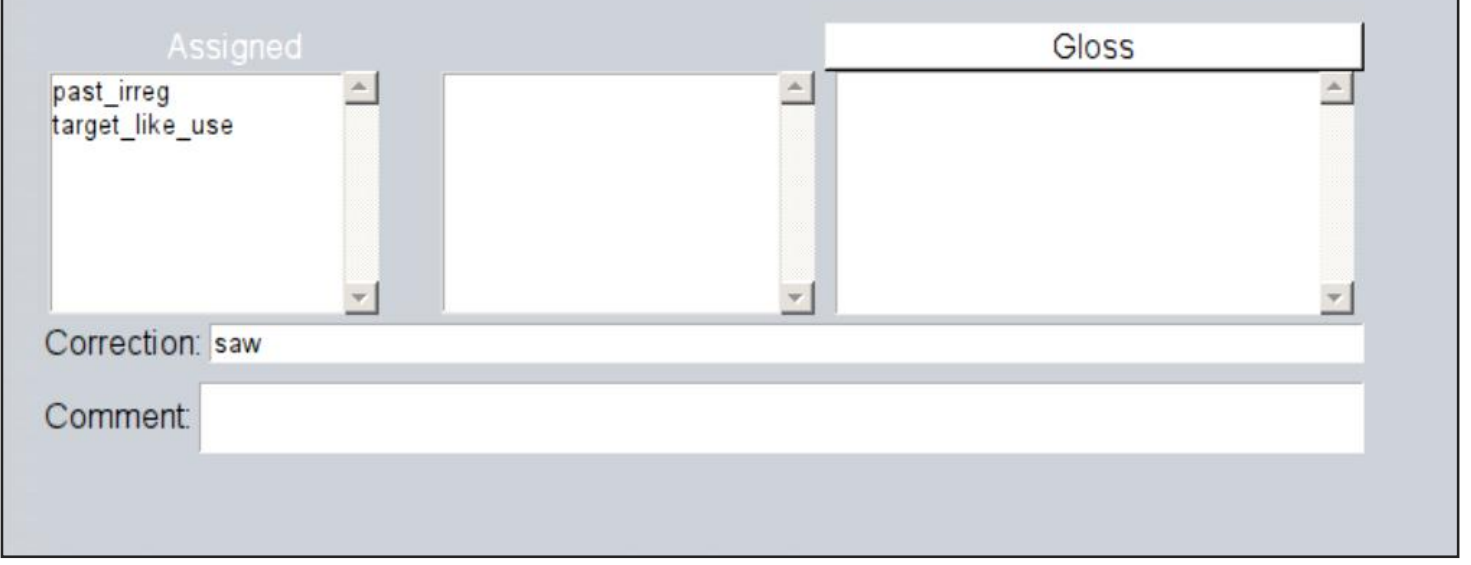


Appendix 10. UAM Corpus tool qualitative analysis

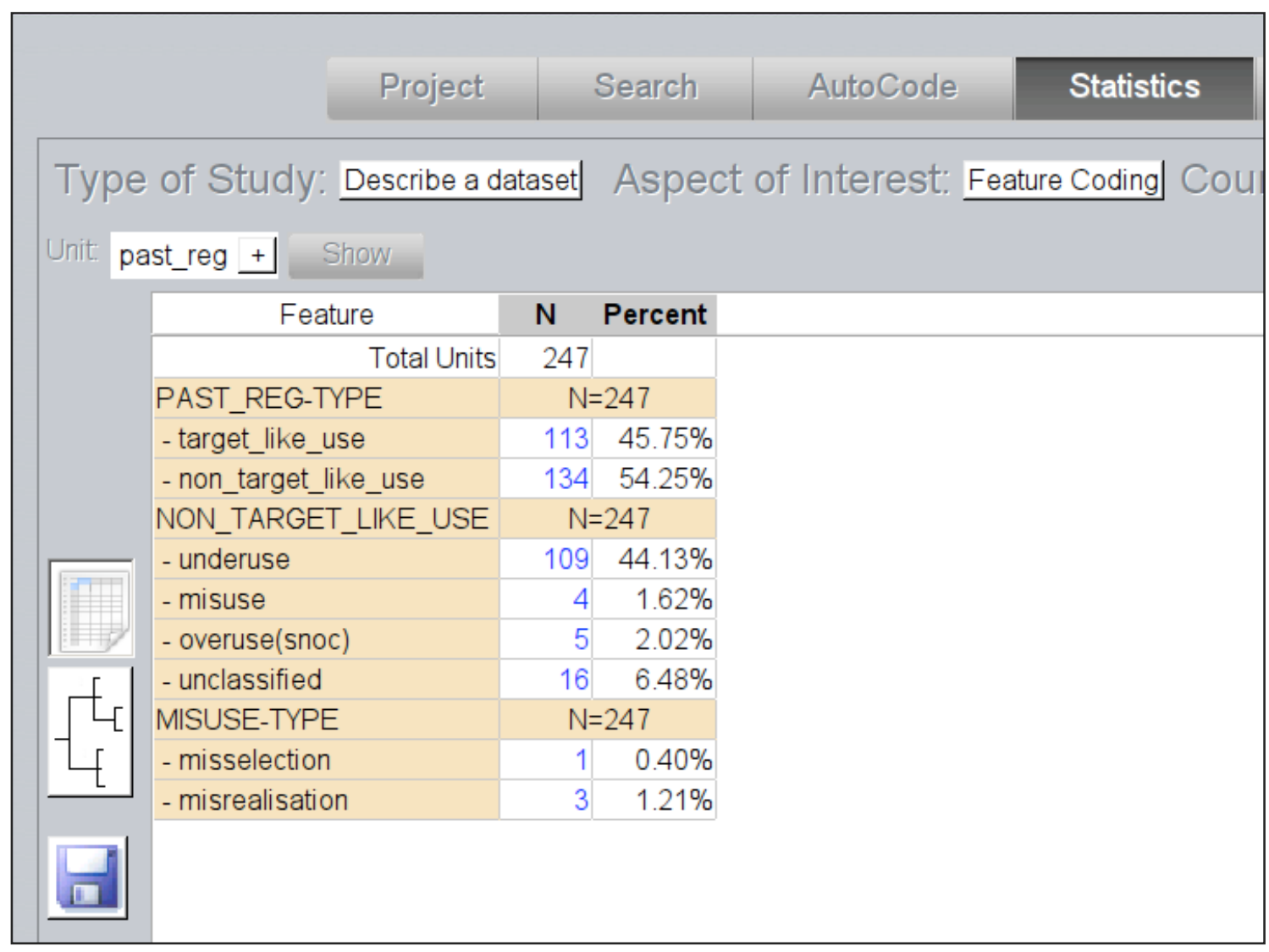

Appendix 11. UAM Corpus tool Data exploration

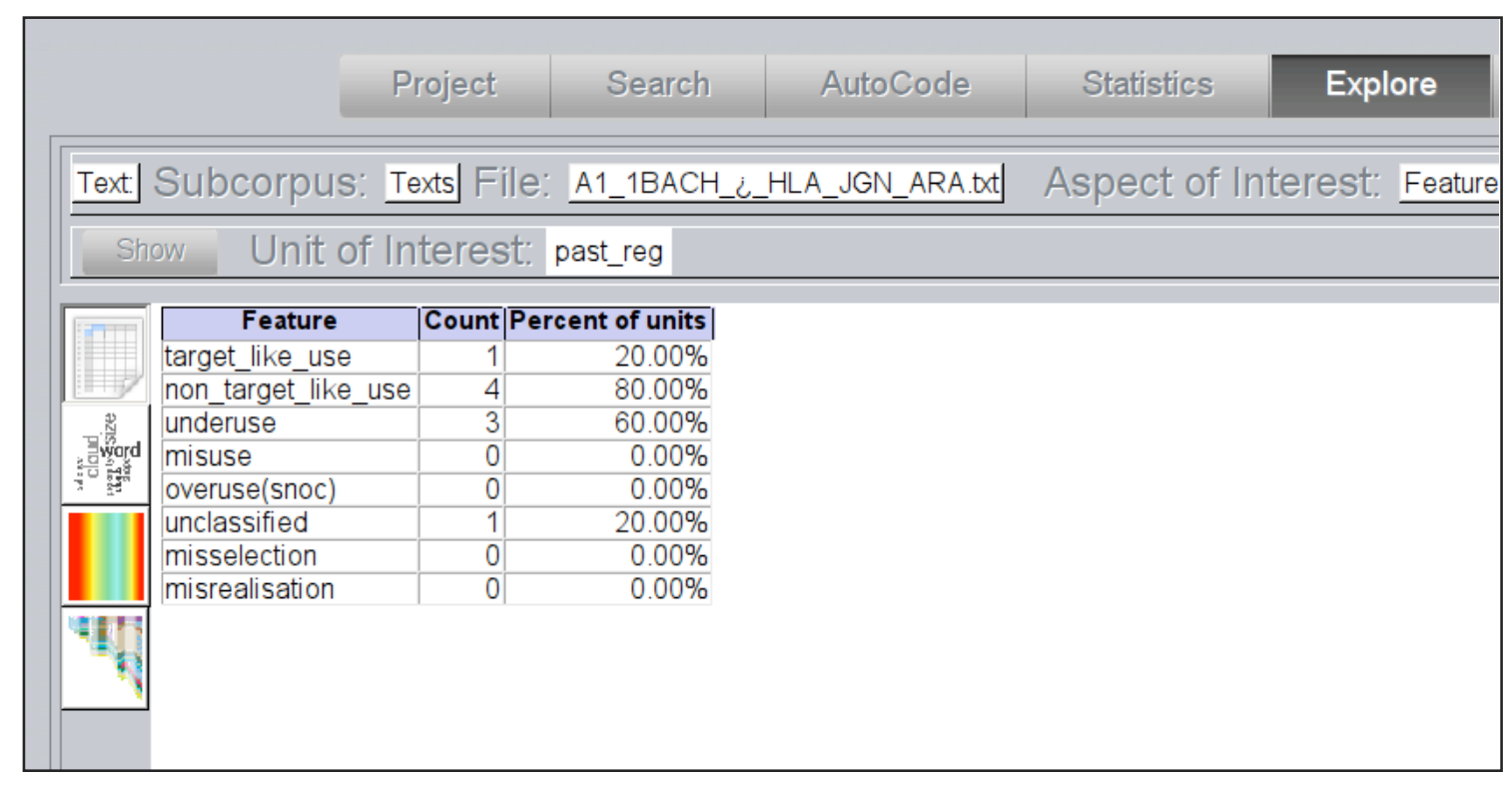

